

\section{DISCLAIMER}

This report was prepared as an account of work sponsored by an agency of the United States Government. Neither the United States Government nor any agency Thereof, nor any of their employees, makes any warranty, express or implied, or assumes any legal liability or responsibility for the accuracy, completeness, or usefulness of any information, apparatus, product, or process disclosed, or represents that its use would not infringe privately owned rights. Reference herein to any specific commercial product, process, or service by trade name, trademark, manufacturer, or otherwise does not necessarily constitute or imply its endorsement, recommendation, or favoring by the United States Government or any agency thereof. The views and opinions of authors expressed herein do not necessarily state or reflect those of the United States Government or any agency thereof. 


\section{DISCLAIMER}

Portions of this document may be illegible in electronic image products. Images are produced from the best available original document. 
The facilities of Argonne National Laboratory are owned by the United States Government. Under the terms of a contract (W-31-109-Eng-38) among the U.S. Department of Energy, Argonne Universities Association and The University of Chicago, the University employs the staff and operates the Laboratory in accordance with policies and programs formulated, approved and reviewed by the Association.

\section{MEMBERS OF ARGONNE UNIVERSITIES ASSOCIATION}

The University of Arizona Carnegie-Mellon University Case Western Reserve University The University of Chicago University of Cincinnati Illinois Institute of Technology University of Illinois Indiana University The University of lowa Iowa State University
The University of Kansas

Kansas State University

Loyola University of Chicago

Marquette University

The University of Michigan

Michigan State University

University of Minnesota

University of Missouri

Northwestern University

University of Notre Dame
The Ohio State University Ohio University

The Pennsylvania State University

Purdue University

Saint Louis University

Southern IIlinois University

The University of Texas at Austin Washington University

Wayne State University

The University of Wisconsin-Madison

\section{NOTICE}

This report was prepared as an account of work sponsored by an agency of the United States Government. Neither the United States Government or any agency thereof, nor any of their employees, mäke any warranty, express or implied, or assume any legal liability or responsibility for the accuracy, completeness, or usefulness of any information, apparatus, product, or process disclosed, or represent that its use would not infringe privately owned rights. Reference herein to any specific commercial product, process, or service by trade name, mark, manufacturer, or otherwise, does not necessarily constitute or imply its endorsement, recommendation, or favoring by the United States Government or any agency thereof. The views and opinions of authors expressed herein do not necessarily state or reflect those of the United States Government or any agency thereof.

This informal report presents preliminary results of ongoing work or work that is more limited in scope and depth than that described in formal reports issued by the Energy and Environmental Systems Division.

Printed in the United States of America. Available from National Technical Information Service, U. S. Department of Commerce, 5285 Port Royal Road, Springfield, Virginia 22161 


\section{ARGONNE NATIONAI. I.ABORATORY \\ 9700 South Cass Avenue \\ Argonne, Illinois 60439}

ANL/EES-TM-129

IN PURSUIT OF CLEAN AIR:

A DATA BOOK OF PROBLEMS AND

STRATEGIES AT THE STATE LEVEL

SUPPLEMENT

by

D.B. Garvey, S.B. Moser, and D.G. Streets

Energy and Environmental Systems Division

Integrated Assessments and Policy Evaluations Group

August 1980

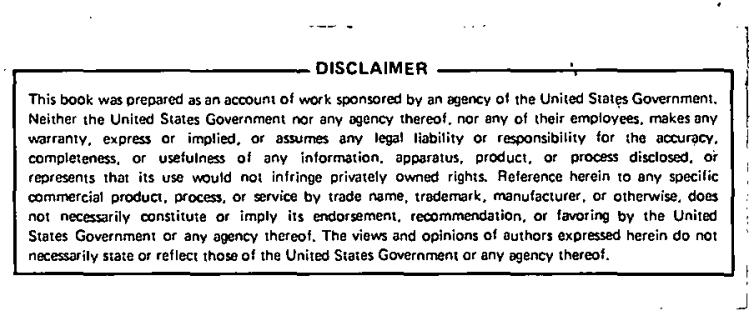

work sponsored by

U.S. DEPARTMENT OF ENERGY

Assistant Secretary for Environment

office of Environmental Assessments

Regulatory Analys is Division 
THIS PAGE

\section{WAS INTENTIONALLY LEFT BLANK}


LIST OF ABBREVIATIONS . . . . . . . . . . . . . . . . . . . . . . . . vi

ABSTRACT. . . . . . . . . . . . . . . . . . . . . . . . 1

' 1 INTRODUCTION . . . . . . . . . . . . . . . . . . . . . . . . . 1

2 EPA REGULATORY ACTIVITIES . . . . . . . . . . . . . . . . . . . . . 3

2.1 Background. . . . . . . . . . . . . . . . . . . . . 3

2.2 Conditional Approval. . . . . . . . . . . . . . . . . . . . . 3

2.3 Guidelines for SIPs with Extensions . . . . . . . . . . . . . . . 4

2.4 Impact of Revised PSD Regulations . . . . . . . . . . . . . . . . 4

2.4.1 Definition of Major Source. . . . . . . . . . . . . . 4

2.4.2 Geographic Applicability . . . . . . . . . . . . . . . . 5

2.4.3 Fugitive Dust. . . . . . . . . . . . . . . . . . 5

3. NONATTAIMMENT AREAS. . . . . . . . . . . . . . . . . . . . . 6

3.1 Redesignations of Areas . . . . . . . . . . . . . . . . . 6

3.2 Redesignations at the Subcounty Level . . . . . . . . . . . . . 16

3.2.1 Sulfur Dioxide . . . . . . . . . . . . . . . . . . 16

3.2.2 Total Suspended Particulates . . . . . . . . . . . . 18

3.2.3 Nitrogen Dioxides. . . . . . . . . . . . . . . . . 18

3.2 .4 Carbon Monoxide. . . . . . . . . . . . . . . . . . . . 18

3.2.5 Ozone. . . . . . . . . . . . . . . . . . . . . . . 18

4 REVISED SIPS . . . . . . . . . . . . . . . . . . . . . . . . 19

4.1 Overview of SIPs. . . . . . . . . . . . . . . . . . . . . . . 19

4.1.1 Detailed Status of SIPs. . . . . . . . . . . . . 22

4.1.2 Sanctions. . . . . . . . . . . . . . . . . . . 22

4.2 Attainment Strategies . . . . . . . . . . . . . . . . . . 26

4.2.1 Sulfur Dioxide . . . . . . . . . . . . . . . . 26

4.2.2 Total Suspended Particulates . . . . . . . . . . . . 29

4.2.3 Nitrogen Dioxide.................... . . 30

4.2.4 Ozone and Carbon Monoxide. . . . . . . . . . . . . . 30

REFERENCES. . . . . . . . . . . . . . . . . . . . . . . . 31

APPENDIX A Maps of Designated Nonattainment Areas as of

July 1, 1980. . . . . . . . . . . . . . . . . . . . 33

APPENDIX B Coal Production, Quality, and Reserves........... . 77

APPENDIX C Maps of PSD Class I Areas . . . . . . . . . . . . . . . 181

APPENDIX D Maps of County Names for States Covered in Appendix B . . . . 253 
FIGURES

3.1 U.S. Counties Containing Designated Nonattainment Areas for $\mathrm{SO}_{2}$ as of July 1,1980 . . . . . . . . . . . . . . . . . . . . . 7

3.2 U.S. Counties Containing Designated Nonattainment Areas for TSP as of July l, 1980. . . . . . . . . . . . . . . . . . . . . 8

3.3 U.S. Counties Containing Designated Nonattainment Areas for CO as of July 1, 1980 . . . . . . . . . . . . . . . . . . . . . 9 9

3.4 U.S. Counties Containing Designated Nonattainment Areas for $0_{3}$ as of July 1,1980 . . . . . . . . . . . . . . . . . . . . . 10

3.5 U.S. Counties Containing Designated Nonattainment Areas for $\mathrm{NO}_{\mathrm{x}}$ as of May 1979 and July 1980. . . . . . . . . . . . . . . . 11

3.6 U.S. Counties Containing Redesignated Nonattainment Areas for $\mathrm{SO}_{2}$ : Changes between May 1979 and July 1980. . . . . . . . . . . . 12

3.7 U.S. Counties Containing Redesignated Nonattainment Areas for TSP: Changes between May 1979 and July 1980. . . . . . . . . . . . 13

3.8 U.S. Counties Containing Redesignated Nonattainment Areas for CO: Changes between May 1979 and July 1980 . . . . . . . . . . . . 14

3.9 U.S. Counties Containing Redesignated Nonattainment Areas for $0_{3}$ : Changes between May 1979 and July 1980............. . 15

3.10 Boundaries of Federal Regions . . . . . . . . . . . . . . . . . . . 17

4.1 Status of Revised SIPs as of July 1980. . . . . . . . . . . . . . . 20

4.2 Status of Inspection and Maintenance Programs as of July 1980 . . 21

TABI,ES

3.1 Number of Counties in Violation of Primary NAAQS. Designations as of July 1, 1980, Compared to May 1979 . . . . . . . . . . . . . . 16

4.1 Status of Revised SIPs for Primary Standard Nonattainment Areas, as of July 1, 1980. . . . . . . . . . . . . . . . . . . . . . 23

4.2 Summary of Status of Revised SIPs for Primary Nonattainment Areas, as of July 1980 . . . . . . . . . . . . . . . . . . . . . . . 24 
The Clean Air Act Amendments of 1977 reaffirmed a national commitment to clean air and set rigorous requirements to achieve and maintain the National Ambient Air Quality Standards across the nation. The solutions to air quality problems, however, must take place at the state and local levels. The strategies adopted by the states concern the U.S. Department of Energy because it must identify possible conflicts between a national energy policy of increased coal use and the pursuit of clean air.

To summarize the state strategies, we prepared a five-volume report on air quality, nonattainment areas, and attainment strategies of each state, based in part on the revised State Implementation plans (SIPs) submitted in accordance with the 1977 amendments. The report is entitled In Pursuit of Clean Air: A Data Book of Problems and Strategies at the State Level, Argonne National Laboratory Report ANL/EES-TM-90, Vols. 1-5 (February 1980).

This report, a supplement to the five-volume set, summarizes changes in the status of revised SIPs since the previous report. It also includes maps of nonattainment areas that have been redesignated between May 1979 and July 1, 1980. In addition, maps and data relating to county-level coal production, coal reserves, and coal quality are presented. Finally, state maps of PSD Class I areas complete the air quality data.

This project has been funded by the U.S. Department of Energy, Assistant Secretary for Environment, Office of Environmental Assessments, Regulatory Analys is Division (formerly office of Technology Impacts, Policy Analysis Division). Doug Carter was project officer. The coal data were provided by Teknekron Research Inc. 


\section{LIST OF ABBREVIATIONS}

Btu

British thermal unit

$\mathrm{CO}$ carbon monoxide

DOT

U.S. Department of Transportation

EPA

U.S. Environmental Protection Agency

EX-EX

expected exceedances

$\mathrm{HC}$ hydrocarbons

$I \& M$

inspection and maintenance

MPR mult ipoint rollback

NAAQS

National Ambient Air Quality Standards

$\mathrm{NO}_{\mathbf{x}}$ nitrogen oxides

NSO

nonferrous smelter order

$\mathrm{O}_{3}$

ozone

PSD

prevention of significant deterioration

RACT

SIP

$\mathrm{SO}_{2}$

TSP

reasonably available control technology

state implementation plan

sulfur dioxide

total suspended particulates 
IN PURSUIT OF CLEAN AIR:

A DATA BOOK OF PROBLEMS AND

STRATEGIES AT THE STATE LEVEL

SUPPLEMENT

by

D.B. Garvey, S.B. Moser, and D.G. Streets

\section{ABSTRACT}

The Clean Air Act Amendments of 1977 and EPA regulations set stringent requirements for the control of emissions in areas where the National Ambient Air Quality Standards were being exceeded. This supplement updates a previous five-volume summary of nonattainment area designations and attainment strategies of the states as of July 1, 1980. It also contains maps of PSD Class $I$ areas and additional information on coal production, coal reserves, and coal quality.

\section{INTRODUCTION}

The Clean Air Act Amendments of 1977 set rigorous requirements for the cleanup of those areas of the United States where the pollutants in the ambient air exceeded the levels set by the National Ambient Air Quality Standards. The legislation established December 31, 1982, as a deadline for attainment, with a possible extension to December 31,1987 , for two of the six criteria pollutants. To ensure that timely attainment would occur, Congress also set a deadline for the submission of state implementation plans (SIPs) to clean up nonattainment areas. These SIPs outlined additional controls for existing sources and the review procedures and emission 1 imits for new sources. The state plans were to be submitted to the U.S. Environmental Protection Agency (EPA) by January 1, 1979, and to be approved by EPA and in effect by July 1, 1979. The consequences of missing the deadlines were restrictions on new source construction and the possible loss of certain federal funding. In addition, the law required EPA to promulgate regulations if states failed to adopt adequate implementation plans.

The EPA, charged with administering the 1977 amendments, set guidelines for the designations of nonattainment areas and for the contents of approvable SIPs. The states designated areas and then submitted plans for either different pollutants, different areas, or both. The EPA reviewed the designations and the SIPs, either approving or disapproving them. As of July 1, 1980, one year after the original deadline for approval, a number of SIPs for subcounty nonattainment areas are still not complete. Only two states -- Wyoming and Mississippi -- have complete, EPA-approved plans. The remaining states continue to redesignate nonattainment areas, submit partial plans, and correct deficiencies in conditionally approved plans. 
The location of nonattainment areas and the SIPs for those areas are matters that directly concern energy policy makers. For example, any proposal to reduce oil consumption by converting existing oil-burning facilities to coal must address the effect of possible increased emissions on nonattainment areas and the likely restrictions the sources would face. To make this and similar tasks easier, we compiled a data book of nonattainment areas, SIP attainment strategies, and other air-quality policy data. This information was published in a five-volume report covering all 48 contiguous states.1

This present volume supplements the earlier report. by updating EPA regulations, nonattainment designations, and SIPs for nonattainment areas. Section 2 summarizes EPA regulatory actions between May 19.79 and July 1980; Sec. 3 provides new maps of U.S. counties containing nonattainment areas as of July 1, 1980, and discusses changes in nonattainment designations; and Sec. 4 addresses new developments in SIP attainment strategies. Appendix A presents maps of the actual subcounty areas that have been redesignaced as nonattain ment since May 1979 (the date of material in the five-volume report). Appendix B p'rovides state maps of coal production levels and coal quality at the county level, plus tables of coal reserves and additional coal production and quality data. In Appendix $C$, state maps illustrate the locations and sizes of all, mandated Prevention of Significant Deterioration (PSD) Class I areas. Finally, Appendix $D$ contains maps of the county names for all the states covered in Appendix B. 


\section{EPA REGULATORY ACTIVITIES}

\subsection{BACKGROUND}

According to the 1977 clean Air Act Amendments and subsequent EPA regulations, states were required to submit new state implementation plans for all nonattainment areas by January 1, 1979. The SIPs were to outline strategies and regulations necessary to attain the standards for the criteria pollutants -- sulfur dioxide $\left(\mathrm{SO}_{2}\right)$, nitrogen oxides $\left(\mathrm{NO}_{\mathrm{x}}\right)$, total suspended particulates (TSP), carbon monoxide (CO), and ozone $\left(0_{3}\right)^{--}$by December 31 , 1982. A five-year extension for attainment of the $C 0$ and $O_{3}$ standards to December 31,1987 , was possible if the SIP indicated that, despite the imposition of reasonably available control technology (RACT) on stationary sources of hydrocarbons (precursors of ozone), attainment could not be achieved by the earlier deadline. If a state failed to have an approved SIP in effect by July 1, 1979, EPA would impose sanctions on that state. No new major sources of a pollutant could be built. in an area that was designated nonattainment for that pollutant, and federal funds for highway projects and sewage treatment plants could be restricted or withheld.

\subsection{CONDITIONAL APPROVAL}

Only one state - - Wyoming - actually had an EPA-approved SIP in effect by the 1979 deadline. The EPA developed several administrative procedures to avoid imposing sanctions on many states. The agency accepted, reviewed, and approved submissions of partial SIPs (e.g., plans for an individual nonattainment area or plans for a particular pollutant) rather than holding up the process until states submitied SIPs for all nonattainment areas. Furthermore, EPA made possible the conditional approval of a revised SIP. If the SIP was substantially acceptable, with only minor deficiencies, approval was granted, based on the state's agreement to correct the deficiencies by an EPA-determined deadline. Sanctions were not imposed and the state was given time to complete the SIP.

Each conditional approval included a deadline (typically nine months from the action) for the state to submit a correction. In November 1979, EPA declared that conditional approvals would not be extended beyond the time originally given to correct the deficiencies. ${ }^{2}$ It said that "a second conditional approval is not an available option." If a state failed to correct the deficiencies by the conditional approval deadline, EPA planned to simply declare the existing SIP disapproved and impose the restrictions on new sources in nonattainment areas.

By May 1980, 'six states (Colorado, Maine, Massachusetts, North Carolina, New Hampshire, and New York) missed deadlines for corrections of conditionally approved SIPs. The EPA considered "reinstating the ban on new sources, 3 but has not yet formally disapproved any conditionally approved SIP. (See Sec. 4.1 for a detailed discussion of states with conditional approvals and partial submissions.) 


\subsection{GUIDELINES FOR SIPS WITH EXTENSIONS}

States that requested extensions of the deadline for $0_{3}$ and co attainment are to submit further SIP revisions by July 1, 1982. These revisions must include strategies for attainment by December 31, 1987. The EPA expected that the states would collect the data needed to prepare the SIPs in 1980 . Consequently, in 1979 the agency issued air quality and emission data requirements for models that could be used to project attainment. 4 Different levels of ozone modeling were suggested for the major urban areas with deadline extensions; i.e., 'more-complex dispersion models for the areas with the most severe nonattainment (Boston; New York; Philadelphia; Baltimore; Washington, D.C.; Chicago; Houston; St. Louis; and Los Angeles). As of July 1980, EPA was still preparing criteria for SIPs for ozone and had not promulgated the requirements.

States also could have requested an 18-month extension of the deadline for submitting an SIP for the attainment of secondary standards. The extension was to be approved if the state could demonstrate that attainment would require emission reductions beyond those achievable with RACT applied to stationary sources. If an extension was granted, a revised SIP was to be submitted by July 1, 1980, and to be approved by January 1, 1981 .

secondary standards differing from primary standards have been set only for $\mathrm{SO}_{2}$ and $\mathrm{TSP}$. Only six areas in the nation violate the secondary $\mathrm{SO}_{2}$ standards; secondary TSP violations are much more widespread. All of the extensions requested for secondary standards were for TSP. The states typically indicated that attainment would require control of nontraditional sources of particulates (for example, resuspended road dust, construction and demolition dust, tire particles, dust from unpaved roads). Control techniques for these nontraditional sources are not well developed and have not been covered in any EPA. Control Guidance Document. The EPA, however, plans to enforce the deadline for SIP submissions. ${ }^{2}$ The 1977 amendments did not establish any deadline for attainment of the secondary standards other than "as expeditiously as possible." Consequently, according to a recent EPA memo, $S$ the agency will not penalize new sources if an SIP for the attainment of the secondary standards is late.

\subsection{IMPACT OF REVISED PSD REGULATIONS}

The EPA's regulations for clean air areas (PSD regulations) were reviewed in the court case of Alabama Power et al. vs. Costle.6. Although the rules were for PSD areas, the definition of an emissions source subject to review and the geographic applicability of rules affect nonattainment regulations as well. Consequently, revised PSD regulations promulgated August 7 , 1980 , also addressed the requirements for nonattainment areas.

\subsubsection{Definition of Major Source}

Under the new PSD rules, new sources with the potential to emit more than 100 tons per year of a criteria pollutant will be reviewed for air quality impacts and operators of such sources will need a permit before beginning construction. "Potential to emit" is defined as the maximum design 
capacity of the source, except as constrained by federally enforceable permit conditions. These permit conditions include emission limits, hours of opera$t$ ion, and type of fuel burned. This replaces the previous definition, which was the maximum design capacity of the source without the addition of control equipment. The new definition requires fewer sources to undergo new source review.

The definition of a source depends on its location. All major sources have the potential to emit more than 100 tons per year. In nonattainment areas, however, overall emissions from a "plant" are to be reviewed as well as emissions from each "installation" at a plant. In contrast, a major source in PSD areas is considered to be all the "pollutant-emitting activities" in the same industrial grouping or located contiguously. Similarly, in a PSD area, a plant that increases emissions will not be subject to new source review if it is accompanied by reductions elsewhere in the same plant so that no net increase in emissions results. In nonattainment areas, major new installations within a plant will be reviewed regardless of reductions in emissions elsewhere in the facility.

The EPA argues that this dual definition of source is necessary to reduce total emissions, require the lowest achievable emission rate, and attain NAAQS in nonattainment areas. Agency officials say that the dual definition will apply to only "about $1 \%$ of the nation's facilities," since most facilities are single installations, but "plant complexes where the dual definition would come into play represent roughly $10 \%$ of the nation's pollution." 8

\subsubsection{Geographic Applicability}

The August 1980 rules clarified that new source review in PSD and nonattainment areas is to be pollutant-specific. If a major source of a pollutant is located in an area designated nonattainment for that pollutant, then the requirements of offsets and lowest achievable emission rate apply. Nonattainment review is meant to be an exception to PSD review. Thus the PSD rules apply to any new major source of a criteria pollutant when the source is located outside a nonattainment area.

\subsubsection{Fugitive Dust}

The court also decided that EPA's definition of fugitive dust was incorrect: Instead of being "particulate matter composed of soil which is uncontaminated by pollutants resulting from industrial activity," fugitive dust was simply a particular kind of fugitive emission. In response, EPA deleted the definition from PSD and nonattainment regulations. This deletion may seriously affect EPA policy toward rural fugitive dust as a cause of TSP nonattainment. Under that policy, states could redesignate areas as attainment if they could demonstrate that violations were the result of natural rural dust and not man-made industrial particles. Many states, especially in the arid West and Midwest farming regions, applied the fugitive dust exemption. Iowa, for example, used it to redesignate four nonattainment areas. The possible loss of this exemption could make TSP nonattainment a more serious, longer-term problem, although EPA has not yet made any policy statement on the exemption. 
3 NONATTAINMENT AREAS

\title{
3.1 REDESIGNATIONS OF AREAS
}

\begin{abstract}
Nonattainment areas for the criteria pollutants were initially designated in May 1978.8 Changes in designations have been proposed and some accepted and promulgated by EPA since that date. These redesignations are not. necessarily to attainment status. More frequently, a state has successfully presented a case of inadequate or disputed monitoring data and requested a redesignation to unclassified. In addition, a number of redesignations have been proposed by the states and accepted by EPA, but are waiting out the required public-comment period for final promulgation. Only those redesignations listed as final rulings in the Federal Register are included in this report.
\end{abstract}

In our previous report, we provided maps of nonattainment areas as of May 1979. In this supplement, maps of U.S. counties containing nonattainment areas are current as of July 1, 1980 (Figs. 3.1-3.5). Figures 3.6-3.9 present maps of only those counties with areas that were redesignated between May 1979 and July 1980. In Figs. 3.6 and 3.7, the areas of TSP and $\mathrm{SO}_{2}$ nonattainment are shaded to indicate the designation as of July 1980, without distinguishing the previous designation. For example, an area redesignated as TSP secondary nonattainment originally could have been an area of primary violation or of attainment. No areas have been redesignated for $\mathrm{NO}_{x}$; consequently only one map (Fig. 3.5) is provided. Table 3.1 compares the number of counties in May 1979 and July 1980 that contain nonattainment areas for the primary standards, summed by federal region (Fig. 3.10 displays the federal regions).

In general, the number of counties containing nonattainment areas has been slightly reduced since May 1979. There have been no changes at all in Region VI and changes on $1 y^{\circ}$ for $\mathrm{O}_{3}$ in Region II and $\mathrm{SO}_{2}$ in Region $\mathrm{X}$. Six counties contain nonattainment $\mathrm{SO}_{2}$ areas that have been redesignated -- two in Region $V$ and one each in Regions II, III, IV, and X. The total number of counties containing nonattainment areas for co decreased by two. One county in Region I has become nonattainment, while redesignations to attainment or unclassified occurred in Regions IV and IX.

Ozone continues to be the most widespread nonattainment pollutant, with 524 counties containing nonattainment areas. The reduction from 571 in 1979 resulted when EPA relaxed the ozone standard.

Total suapcnded particulates remain the second most serinus nnnartainment problem, with 227 counties containing nonattainment areas for the primary standards in July 1980. This is a decrease of 21 counties from the May 1979 total. Most of these redesignations, however, have been changes to violations of the secondary standard, not redesignations to attainment. Regions II, VI, and $X$ had no official redesignations for TSP. There were no additional primary TSP nonattainment areas designated, and only one new designation for secondary TSP nonattainment (in Illinois). 


\section{Primary Nonattainment}

Secondary Nonattainment

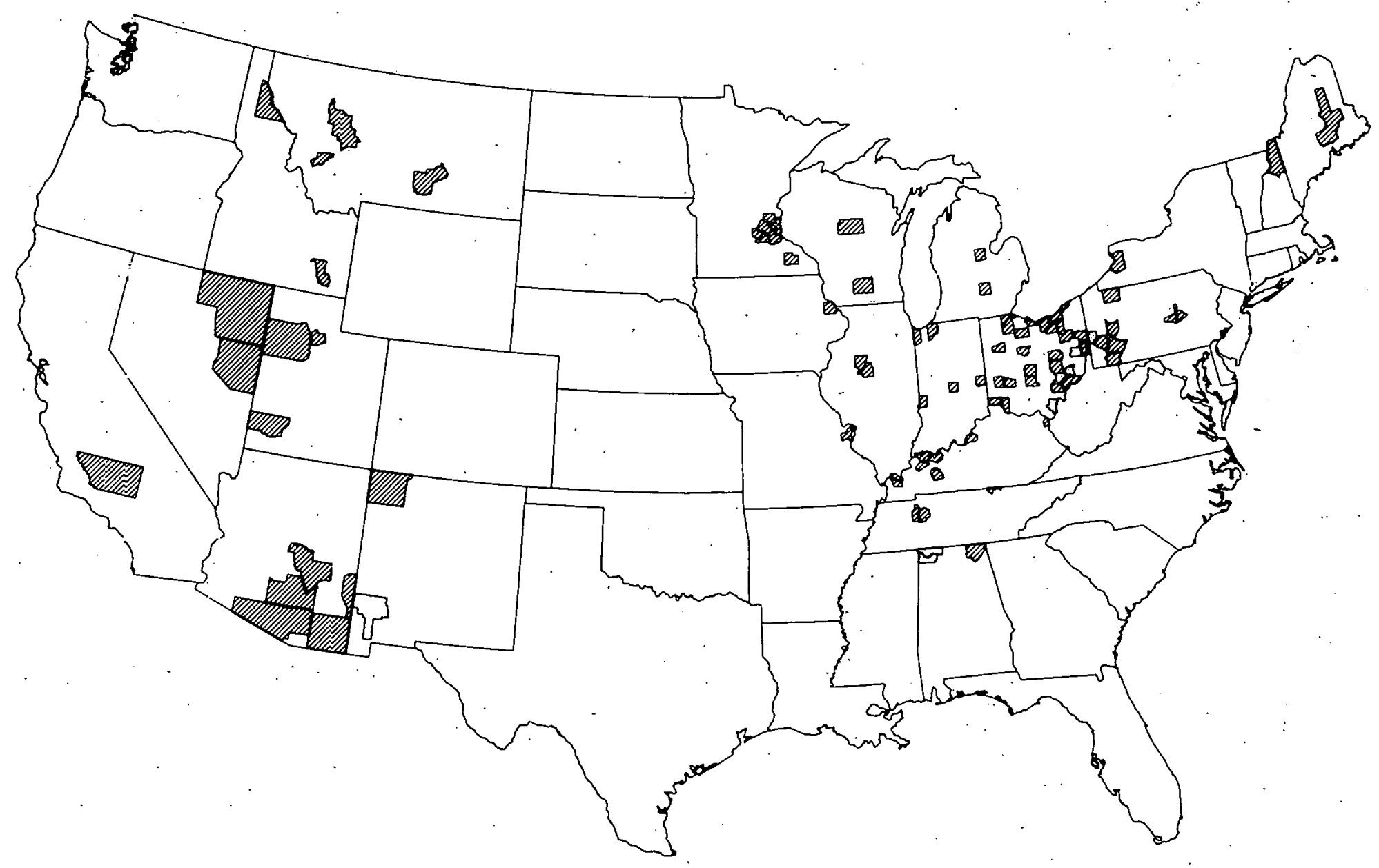

Fig. 3.1 U.S. Counties Containing Nonattainment Areas. for $\mathrm{SO}_{2}$ as of July 1,1980 
Primary Nonattainment

Secondary Nonattainment

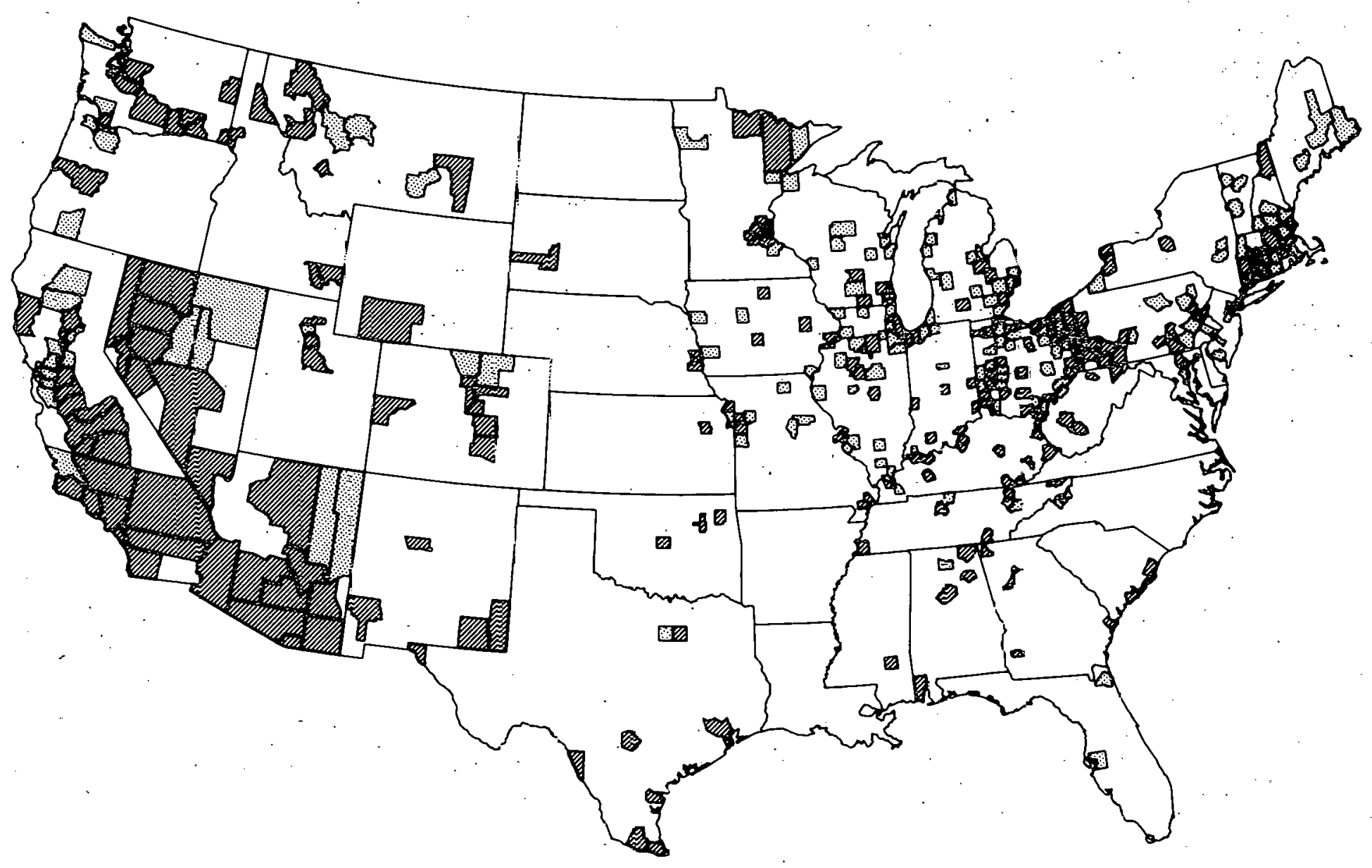

Fig. 3.2 U.S. Counties Containing. Nonattainment Areas for TSP as of July 1, 1980 


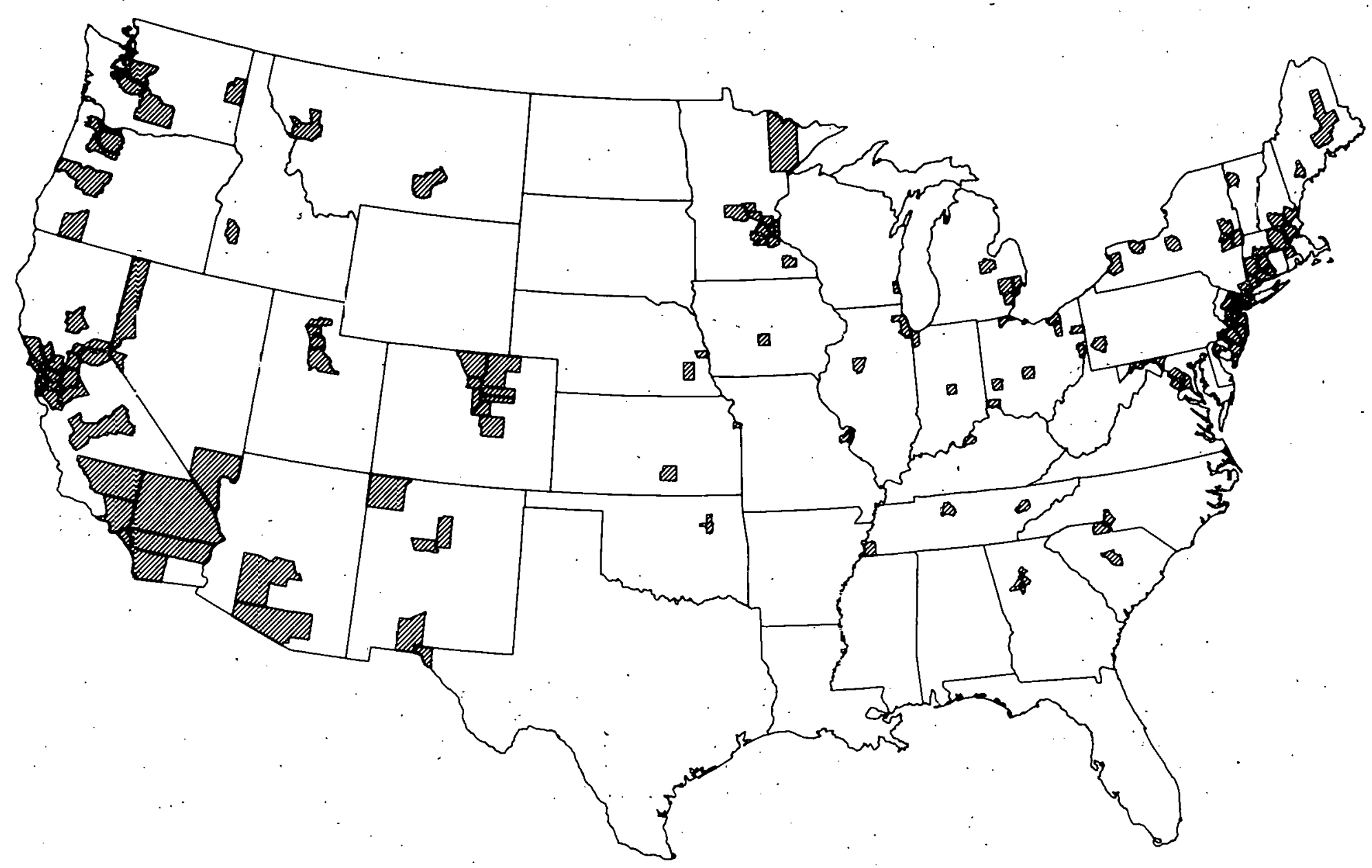

Fig. 3.3 U.S. Counties Containing Nonattainment Areas for CO as of July 1,1980 
Nonattainment

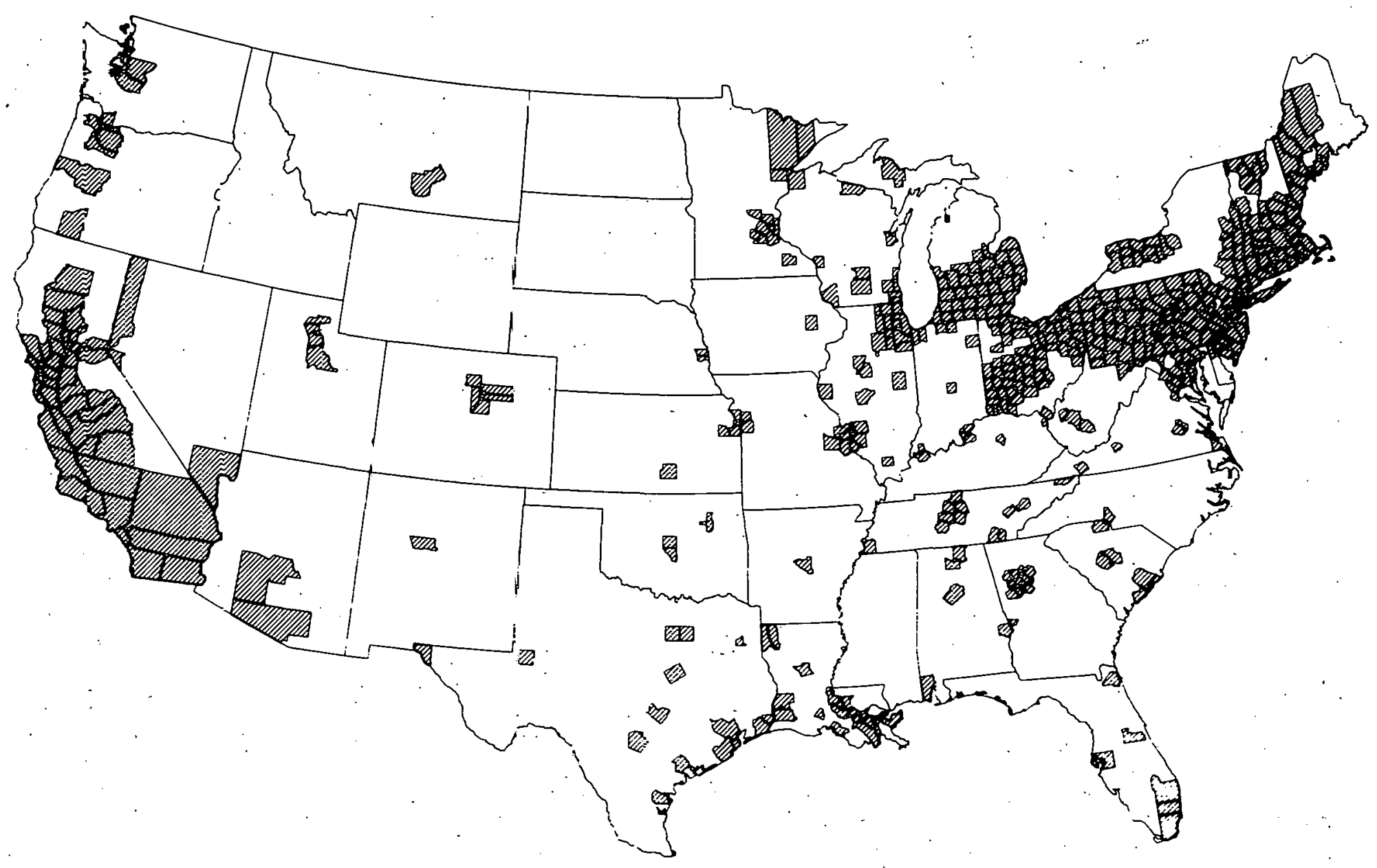

Fig. 3.4 U.S. Counties Containirg Nonattainment Areas for $O_{3}$ as of July 1,1980 


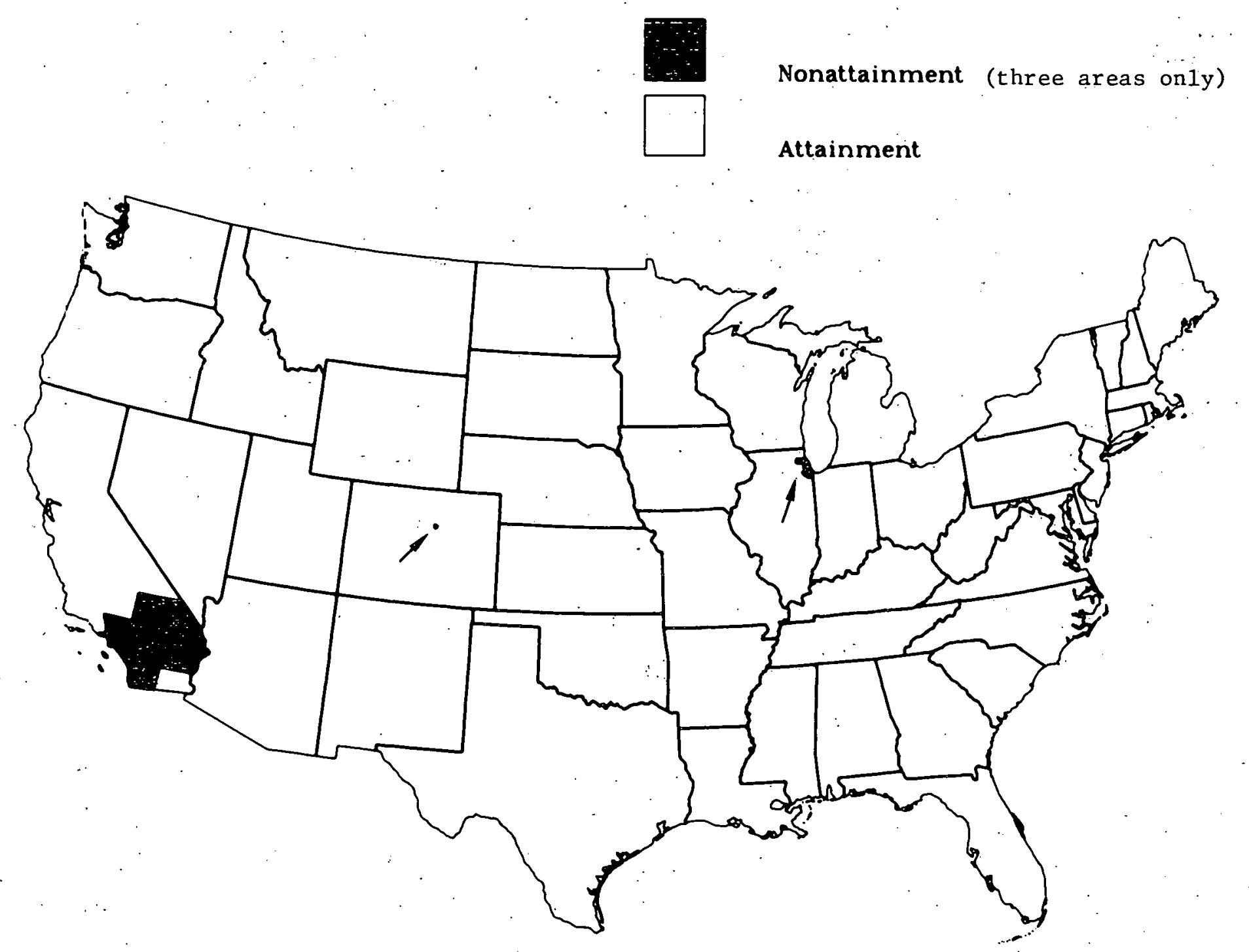

Fig. 3.5 U.S. Counties Containing Nonattainment Areas for $\mathrm{NO}_{\mathbf{x}}$ as of May 1979 and July 1980 


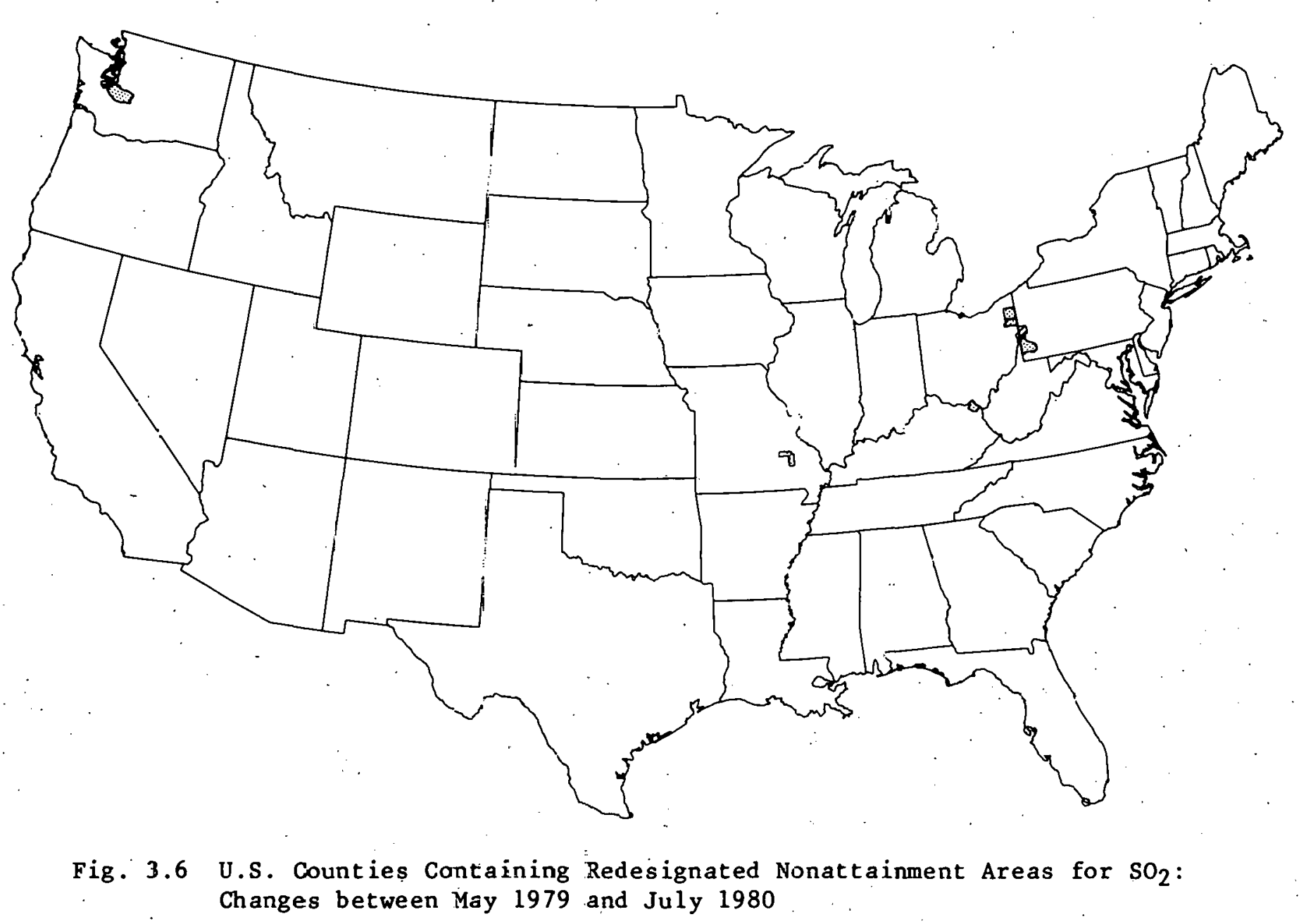




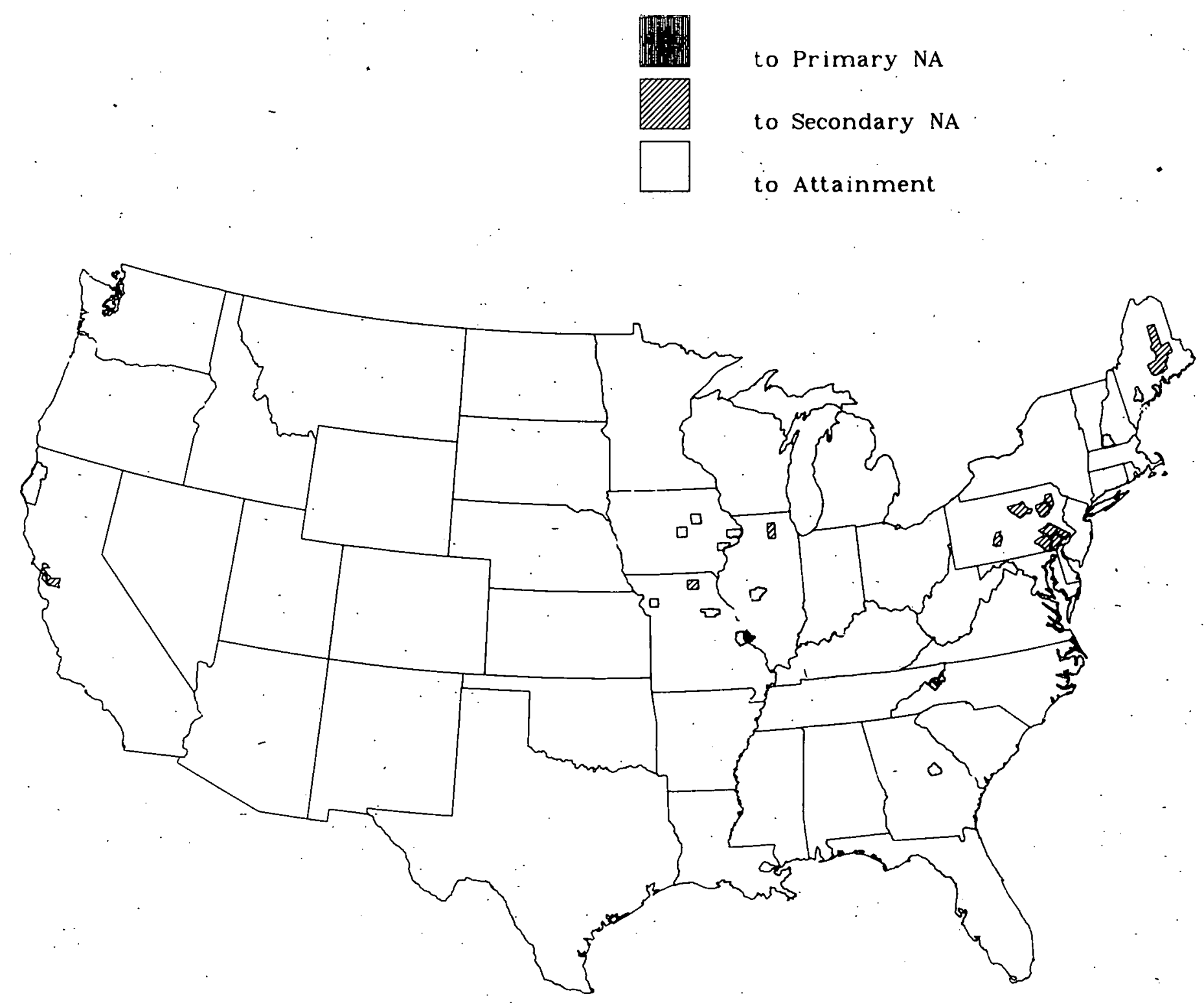

Fig. 3.7 U.S. Counties Containing Redesignated Nonattainment Aréas for TSP: Changes between May 1979 and July 1980 


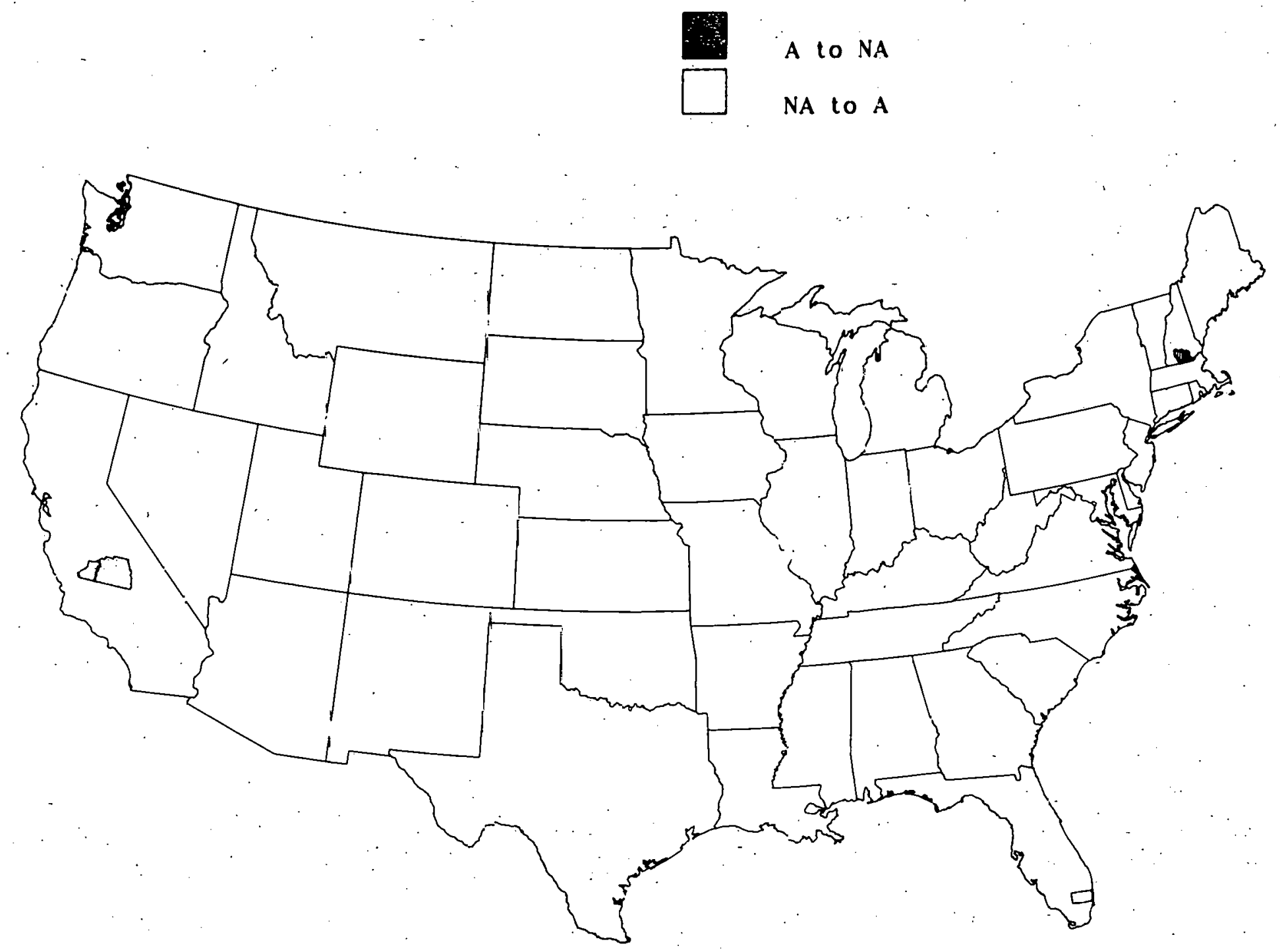

Fig. 3.8 U.S. Counties Containing Redesignated Nonattainment Areas for CO: Charges between May 1979 and July 1980 


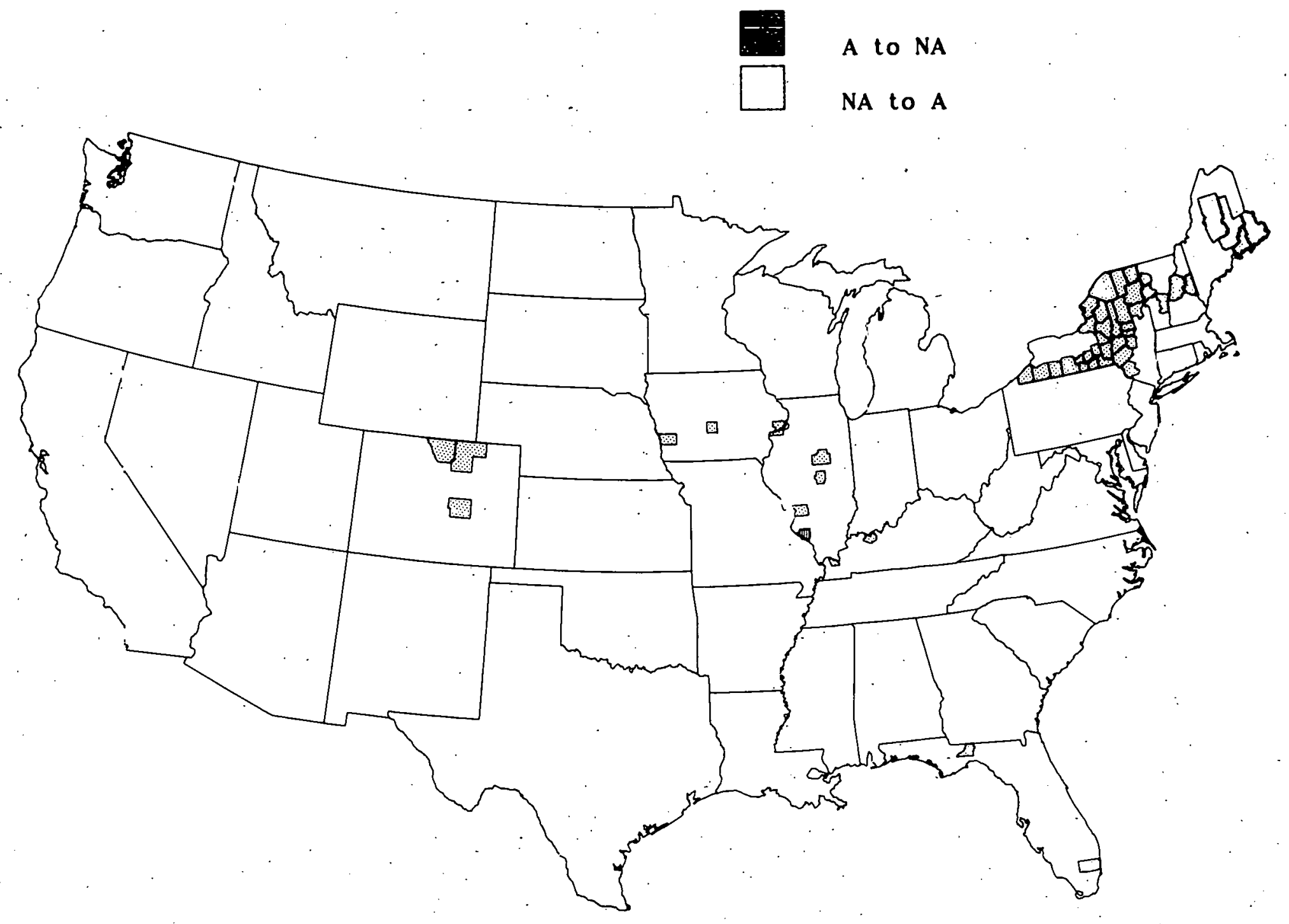

ज

Fig. 3.9 U.S. Counties Containing Redesignated Nonattainment Areas for $\mathrm{O}_{3}$ : Changes between May 1979 and July 1980 
Table 3.1 Number of Counties in Violation of Primary NAAQS. Designations as of July 1, 1980, Compared to May 1979

\begin{tabular}{|c|c|c|c|c|c|c|}
\hline \multirow{2}{*}{$\begin{array}{l}\text { Federal } \\
\text { Region }\end{array}$} & \multirow{2}{*}{$\begin{array}{c}\text { Total No. } \\
\text { of } \\
\text { Countiesa }\end{array}$} & \multicolumn{4}{|c|}{ Number of Counties in Nonattainment } & for: $b$ \\
\hline & & $0_{3}$ & TSP & $\mathrm{CO}$ & $\mathrm{SO}_{2}$ & $\mathrm{NO}_{\mathbf{x}}$ \\
\hline I & 67 & $63 / 56$ & $12 / 11$ & $14 / 15$ & $2 / 2$ & $0 / 0$ \\
\hline II & 83 & $83 / 51$ & $3 / 3$ & $40 / 40$ & $1 / 1$ & $0 / 0$ \\
\hline III & 248 & $90 / 90$ & $31 / 24$ & $8 / 8$ & $11 / 10$ & $0 / 0$ \\
\hline IV & 746 & $53 / 49$ & $33 / 30$ & $11 / 10$ & $12 / 11$ & $0 / 0$ \\
\hline V & 524 & $158 / 155$ & $63 / 62$ & $29 / 29$ & $46 / 44$ & $1 / 1$ \\
\hline VI & 496 & $39 / 39$ & $16 / 16$ & $6 / 6$ & $1 / 1$ & $0 / 0$ \\
\hline VII & .411 & $17 / 14$ & $20 / 14$ & $6 / 6$ & $3 / 2$ & $0 / 0$ \\
\hline VI I I & 292 & $14 / 11$ & $19 / 17$ & $15 / 15$ & $6 / 6$ & $1 / 1$ \\
\hline IX & 89 & $45 / 45$ & $37 / 36$ & $29 / 27$ & $8 / 8$ & $5 / 5$ \\
\hline $\mathrm{X}$ & 119 & $9 / 9$ & $14 / 14$ & $11 / 11$ & $3 / 2$ & $0 / 0$ \\
\hline Total & 3075 & $571 / 524$ & $248 / 227$ & $169 / 167$ & $93 / 87$ & $7 / 7$ \\
\hline
\end{tabular}

a Does not include independent cities.

b1979 data are presented first; 1980 data follow sla'sh.

\subsection{REDESIGNATIONS AT THE SUBCOUNTY LEVEL}

The maps of counties containing nonattainment areas have been supplemented by maps of the actual subcounty areas. These subcounty maps are presented in Appendix $\dot{A}$, along with tahles that summarize air-quality changes for each state: If a state or area is not addressed in this supplement; then its attainment status has not ofticially changed since the preparation of the five-volume report.

\subsubsection{Sulfur Dioxide}

Sulfur dioxide areas were redesignated from nonattainment to attainment in Pennsylvania, Ohio, Kentucky, and Missouri. In Washington, the $\mathrm{SO}_{2}$ nunattainment area was redesignated to unclassified, because EPA claimed that a copper smelter was using an unauthorized, supplementary control system. The smelter company claimed that the system was authorized. After considerable discussion, EPA agreed to designate the area as unclassified until the agency's nonferrous smelter order (NSO) regulations are complete. The smelter probably will be eligible for an exemption.

In all other redesignations, the source that caused the violation was brought into compliance with SIP emission limits or closed down. For example, Ohio redesignated an area in Trumbull and Mahoning Counties after Youngstown's Sheet and Tubing Co. closed its steel plant. In Kentucky, Greenup County reached attainment when a sulfuric acid plant complied with SIP emission limits. In Boyd County, Kentucky, additional controls on a refinery and the shutdown of a chemical plant brought attainment of the $\mathrm{SO}_{2}$ standard. Missouri's Bixby County nonattainment area surrounded an out-of-compliance 


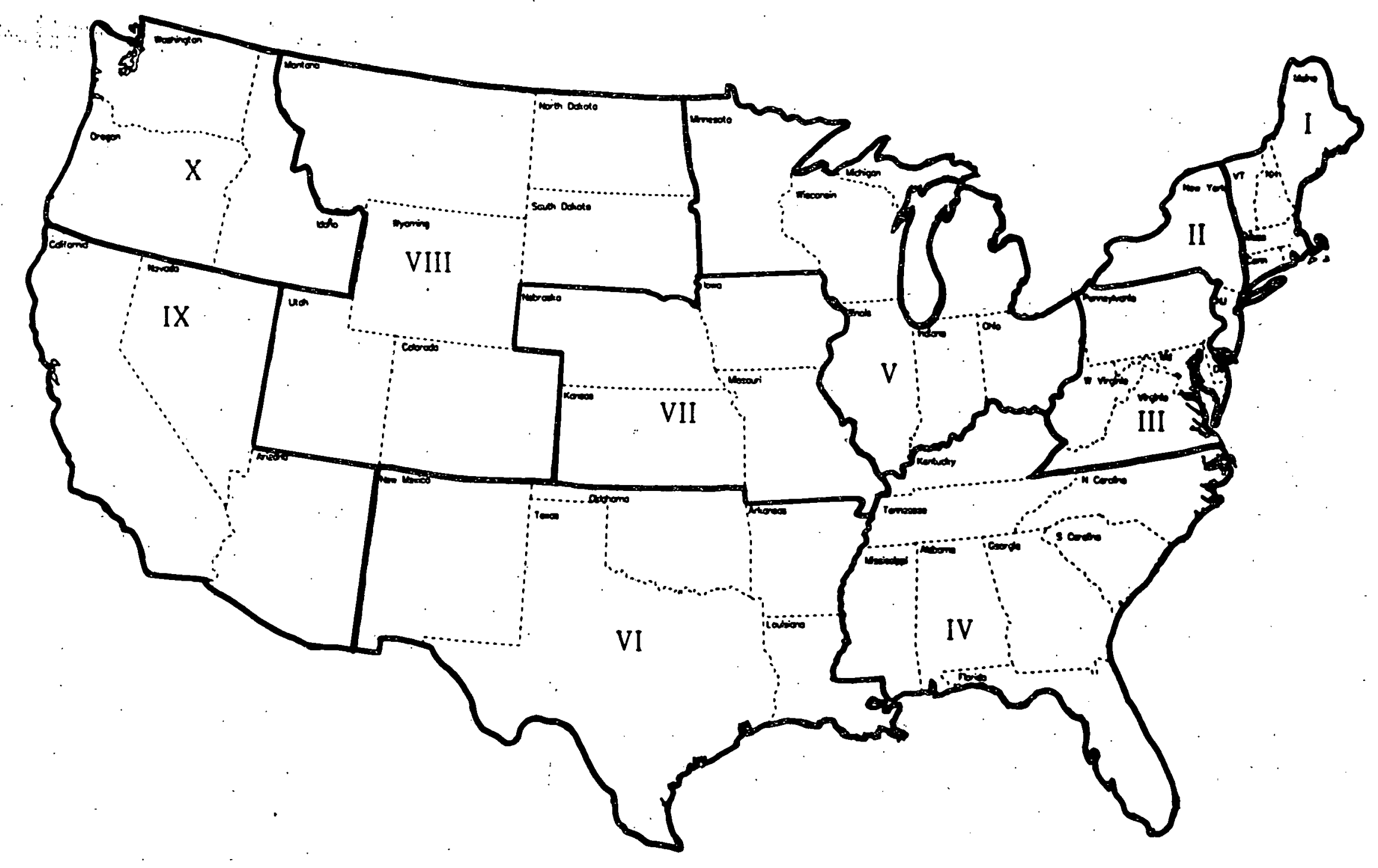

Fig. 3.10 Boundaries of Federal Regions 
primary metals facility. When the source complied, the area attained the standard. In the Allegheny air basin of Pennsylvania, part of the area around Pittsburgh's steel industry was redesignated from primary nonattainment to attainment, and another part of the air basin. was newly designated as violating the secondary $\mathrm{SO}_{2}$ standard. In general, the SIP attainment strategies for $\mathrm{SO}_{2}$ seem to be working -- as sources achieve compliance or close down, the standard is attained.

\subsubsection{Total Suspended Particulates}

Most redesignations of TSP areas were from primary nonattainment to secondary and from secondary nonattainment to attainment or unclassified. In Pennsylvania, for example, seven primary nonattainment areas were reclassified as secondary nonattainment and two secondary nonattainment areas were redesignated as attainment. similar patterns occurred in lalíforiña, lólorado, Maine, and Iowa. Only in Missouri and Illinois have areas classified as primary nonattainment been redesignated directly to attainment. The Illinois SIP indicated temporary construction activity around Springfield was responsible'for the violations; with the end of the construction, attainment was achieved. No information was available on the redesignation from primary nonattainment to attainment for the area around Madrid in Audrain County, Missouri.

\subsubsection{Nitrogen Oxides}

There were no changes in the designations for this pollutant. The Colorado SIP noted that the Denver area, contrary to its designation, was actually in attainment of the standards in 1979; however, the state has not yet requested redesignation.

\subsubsection{Carbon Monoxide}

One new nonattainment area has been designated for co -- Nàshua, New Hampshire, which was changed from unclassified. Florida's nonattainment area in Broward County (north of Miami, including Fort Lauderdale) and California's Tulare and Kings Counties have all been changed from nonattainment to unclassified.

\section{2 .5 Ozone}

Ozone nonattainment areas were typically large geographic areas the size of counties or air basins. The entire states of New York and Vermont were initially designated as nonattainment. Redesignations have reduced the nonattainment area to about half of each state. Major redesignations were also made in Maine and New Hampshire. Florida, Iowa, Illinois, Kentucky, and Colorado each changed the nonattainment designations for several counties. 
4 REVISED SIPS

\subsection{OVERVIEW OF REVISED SIPS}

Revised SIPs were to include the following data for the pollutant for which an area was designated nonattainment: an emission inventory; emission limit on existing sources; a procedure for new source review; and a strategy for making "reasonable further progress" toward attainment of the standard by the statutory deadline. The EPA regional offices reviewed the SIPs and recommended appropriate action -- approval, disapproval, request for more information and continued review, or, if a plan was judged to comply substantially with the regulations, conditional approval. Final promulgation of the ruling was made by EPA headquarters and published in the Federal Register.

As of July 1, 1979, only Wyoming had a complete, revised, EPA-approved SIP for nonattainment areas. One full year later, only Mississippi had joined Wyoming as a possessor of an approved, revised SIP. Both states had limited nonattainment problems. Wyoming has three source-specific TSP nonattainment areas and Mississippi has one TSP nonattainment area. Two states have had a nonattainment SIP disapproved -- South Dakota and Colorado. Although South Dakota has only one nonattainment area (for TSP), its SIP was disapproved because of deficiencies in its new source review procedures. Colorado's plan was disapproved because it failed to include an inspection and maintenance program, as required for SIPs requesting an extension of the $\mathrm{CO}$ or $0_{3}$ dead 1 ine.

Figure 4.1 displays the status of SIPs for nonattainment areas as of July 1, 1980. Fourteen states have had complete SIPs approved either conditionally or without reservation, 21 states have submitted complete plans, parts of which are still under review, and 10 state plans are still not complete. One state, North Dakota, has no nonattainment areas. The SIPs have been submitted piecemeal for specific areas and pollutants and EPA has acted on the SIPs in the same fashion. Consequently, the map is a significant simplification of the status of SIPs.

For an $\mathrm{O}_{3}$ or $\mathrm{CO}$ nonattainment area, any SIP that included an extension of the attainment deadline to December 31,1987 , needed an inspection and maintenance (I\&M) program for motor vehicles. Figure 4.2 displays the status of these I\&M submissions on July 1, 1980, and indicates that six states have incomplete plans. Since that date, Colorado had a program approved (July 10, 1980 ) and the Ohio legislature passed the necessary laws. Indiana maintains that existing laws give the state the necessary enforcement power. The California legislature failed to pass the needed laws in the current session and so its I\&M plan is still incomplete. New York's plan to improve public transportation was rejected by EPA as inadequate to attain the $\mathrm{O}_{3}$ and $C 0$ standards. In Kentucky, two counties (Jefferson and Boone) are setting up an I $\& \dot{M}$ program, while two other counties (Campbell and Kenton) needing the program have refused to comply. Officials in the noncomplying counties said that the area is willing to accept sanctions on funding since only one highway project will be affected. The I\&M program, county officials said, was projected to reduce emissions by on $1 \mathrm{y} 1 \%$, and "the cost would not be justified economically or environmentally."10 As of November 1980, only California and the two counties in Kentucky still lacked an I\&M program. 


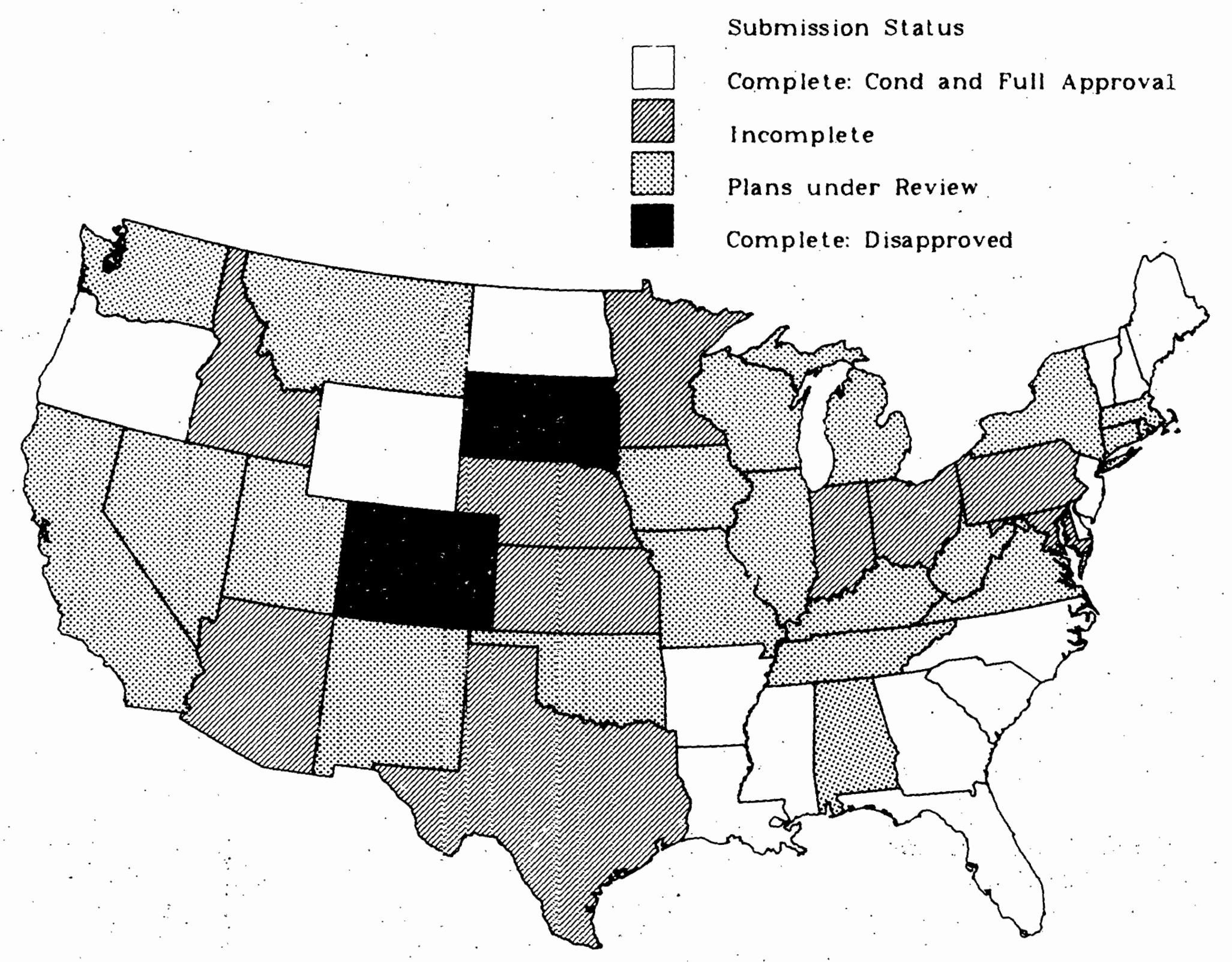

Fig. 4.1. Status of Revised SIPs as of July 1980 


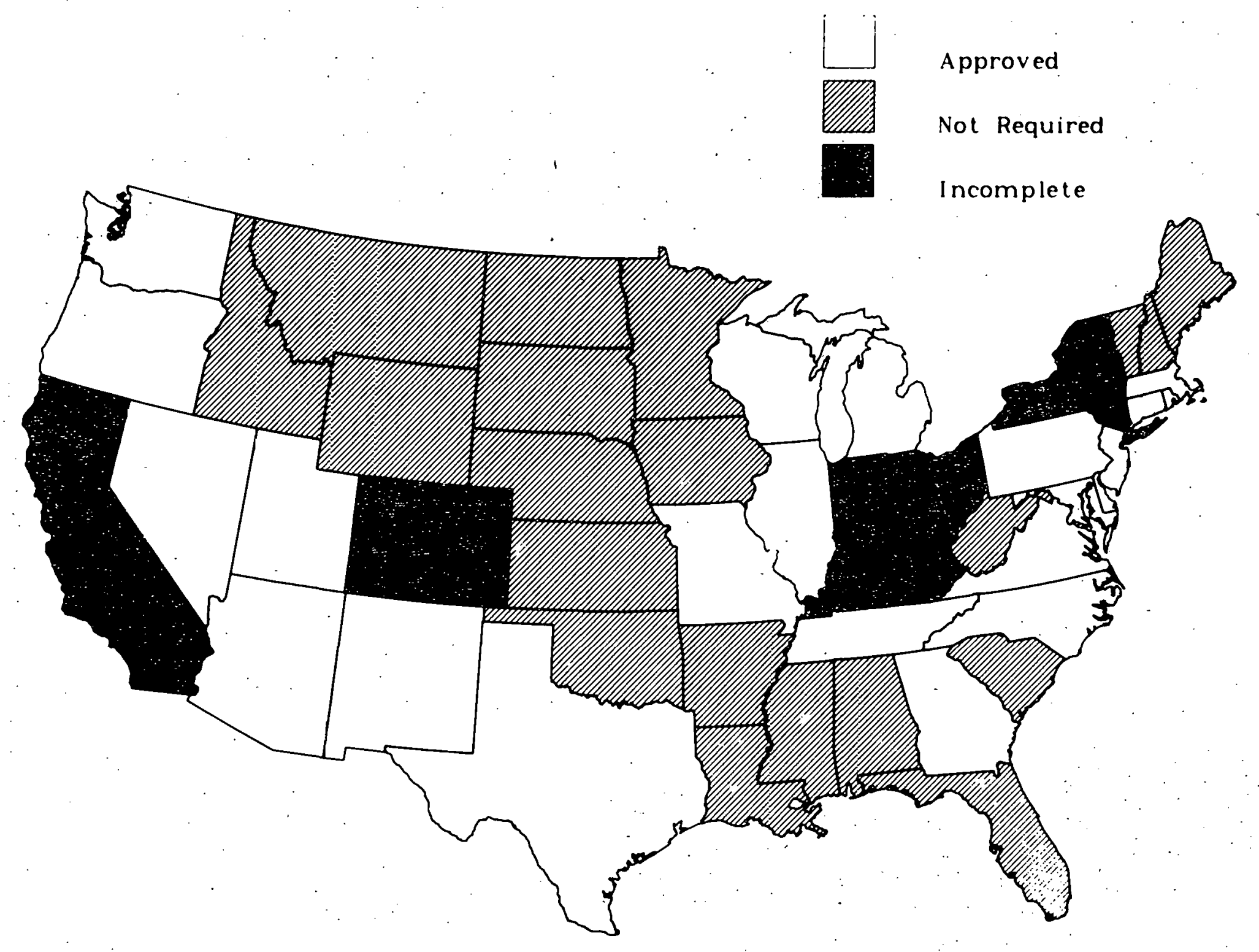

Fig. 4.2 Status of Inspection and Maintenance Programs as of July 1980 


\subsubsection{Detailed Status of SIPs}

Table 4.1 presents the status of SIPs as of July 1980 on a state-bystate basis, organized by federal region. The table lists the SIP status by pollutant and by specific nonattainment area, if the EPA regional office has acted on individual areas. Data for the table came from the EPA headquarters in North Carolina and from conversations with staff members in EPA regional offices.

The classification "under review" covers cases where the SIP has recently been submitted (such as the TSP plan for Pocatello, Idaho, submitted in April 1980), as well as cases where the SIP had been submitted in 1979 (such as New York's $\mathrm{CO} / \mathrm{O}_{3} \mathrm{plan}$ ) but is still under review. We do not have adequate information to state how close these SIPs are to final EPA action.

Only 10 states have areas where no plan has been submitted. Sorne states, however, have submitted plans since July 1980, the date of the table. For example, Minnesota submitted plans in August and September 1980 for all areas except the TSP nonattainment area in International Falls. Pennsylvania has not yet submitted plans for Allegheny County (the area around Pittsburgh) because a modeling error delayed the analysis: Indiana has not completed TSP plans for the counties of Lake (Gary and Hammond), Vigo, and Clark. Ohio submitted a state plan for $\mathrm{SO}_{2}$ that is still under review by EPA. However, the state plan is not necessary to comply with the Clean Air Act deadlines since the EPA is administering its own strategy for $\mathrm{SO}_{2}$ in Ohio, developed in the absence of an approved state plan since 1970. State officials estimate the Ohio TSP plan is at least a year away from approval. Arizona withdrew its SIP for $\mathrm{SO}_{2}$ pending resolution of a disagreement with EPA over appropriate modeling ( see Sec. 4.2.1).

Table 4.2 summarizes the status of SIPs by pollutant. Twenty-four of the 48 contiguous states contained nonattainment areas for the primary $\mathrm{SO}_{2}$ standard. As of July 1980, 6 complete state plans for $\mathrm{SO}_{2}$ had been approved or conditionally approved; 5 states had received conditional approval of a portion of the SIP, and 12 states have plans either still being prepared or under review. Only one state has not submitted any plan at all; however, as noted above, this is Arizona's withdrawn plan. Thirty-nine states were required to prepare TSP plans. By July 1980, 15 complete plans were approved or conditionally approved, 8 states had part of their SIPs conditionally approved, 10 plans were partially under review or in preparation, and, 4 states had failed to submit any plan at all. Of these last four, Minnesota has since submitted a plan, Kansas and Nebraska are still preparing SIPs but have limited nonattainment problems, and ohio, according to otate officials, 11 is more than a year away. from approval.10 All 38 states needing a plan for co attainment have submitted documents, although three plans are incomplete. of the 43 states required to prepare SIPs for $0_{3}$ nonattainment, only Nebraska failed to submit any plan; 25 plans are approved; and 14 are still under review.

\subsubsection{Sanctions}

According to the 1977 Clean Air Act Amendments, any primary nonattainment area not covered by an EPA-approved, revised SIP by July 1, 1979, was 
Table 4.1 Status of Revised SIPs for Primary Standard Nonattainment Areas, as of July 1, 1980

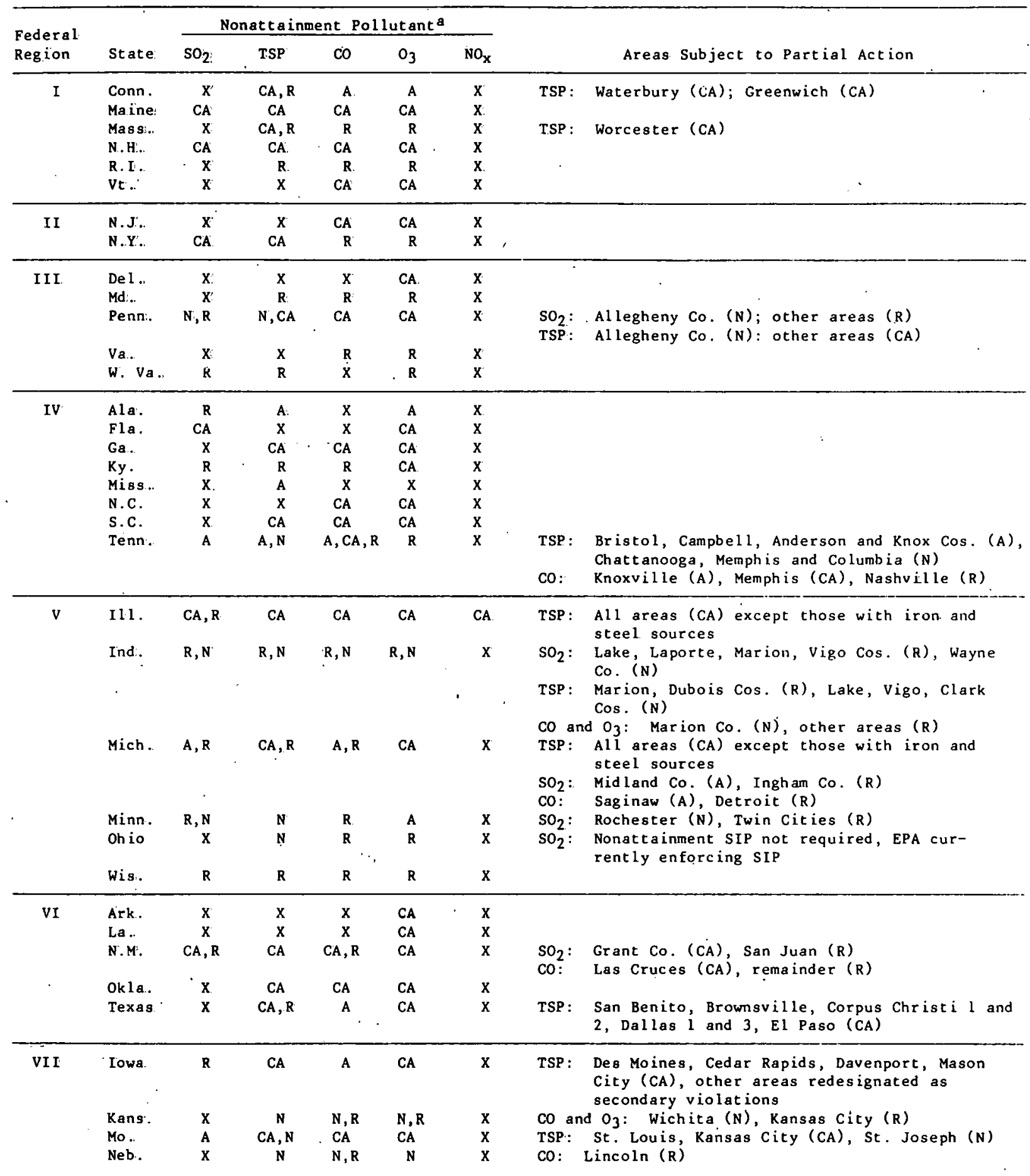


Table 4.1 (Cont' ${ }^{\prime}$ )

\begin{tabular}{|c|c|c|c|c|c|c|c|}
\hline \multirow{2}{*}{$\begin{array}{l}\text { Federal } \\
\text { Region }\end{array}$} & \multirow[b]{2}{*}{ State } & \multicolumn{5}{|c|}{ Nonattainment Pollutant ${ }^{a}$} & \multirow{2}{*}{ Areas Subject to Partial Action } \\
\hline & & $\mathrm{SO}_{2}$ & TSP & $\mathrm{Co}$ & $\mathbf{o}_{3}$ & $\mathrm{NO}_{\mathbf{x}}$ & \\
\hline VIII & $\begin{array}{l}\text { Colo. } \\
\text { Mont. }\end{array}$ & $\begin{array}{r}X \\
A, R\end{array}$ & $\stackrel{\mathrm{CA}}{\mathrm{A}, \mathrm{CA}}$ & $\begin{array}{l}D \\
C A, D\end{array}$ & $\begin{array}{l}\mathbf{D} \\
\mathbf{R}\end{array}$ & $\begin{array}{r}\mathrm{CA} \\
\mathrm{X}\end{array}$ & $\begin{array}{l}\mathrm{CO} \text { and } \mathrm{O}_{3}: \mathrm{D} \text { as a result of failure to include } \mathrm{I} / \mathrm{M} \\
\mathrm{SO}_{2} \text { : Anaconda, Laurel Cos. (A) } \\
\text { TSP: Columbia Falls (A), Colstrip, Missoula, } \\
\text { Butte (CA) }\end{array}$ \\
\hline & N.D. & $\mathbf{x}$ & $\mathrm{x}$ & $\mathbf{x}$ & $\mathrm{x}$ & $\mathrm{x}$ & Co: Billings (CA), Missoula (D) $\quad \because$ \\
\hline & S.D. & $\mathbf{x}$ & D & $\mathrm{x}$ & $\mathrm{x}$ & $\mathrm{x}$ & New source review procedures inadequate \\
\hline & Utah & $A, \ddot{D}$ & D & $\dot{A}, \mathbf{R}$ & $\ddot{R}$ & $\mathrm{x}$ & $\begin{array}{ll}\mathrm{SO}_{2}: & \text { Cedar City (A), Salt Lake and Tooele Cos. (D) } \\
\mathrm{CO}: & \text { Bountiful (A), Ogden, Provo, Salt Lake City } \\
& \text { (R) }\end{array}$ \\
\hline . & Wyo. & $\mathbf{x}$ & $\cdot \mathbf{A}$ & $\mathrm{x}$ & $\mathrm{x}$ & $x$ & . . \\
\hline IX & $\begin{array}{l}\text { Ariz: } \\
\text { Calif. } \\
\text { Nev. }\end{array}$ & $\begin{array}{l}\mathbf{N} \\
\mathbf{R} \\
\mathbf{R}\end{array}$ & $\begin{array}{r}R, N \\
R \\
R\end{array}$ & $\begin{array}{l}\mathbf{R} \\
\mathbf{R} \\
\mathbf{R}\end{array}$ & $\begin{array}{l}\mathbf{R} \\
\mathbf{R} \\
\mathbf{R}\end{array}$ & $\begin{array}{l}\mathrm{X} \\
\mathrm{R} \\
\mathrm{X}\end{array}$ & Pocatello $(N)$, Silver Valley $(R)$ \\
\hline $\mathrm{x}$ & Ida. & $\mathrm{N}, \mathrm{R}$ & $\mathrm{N}, \mathrm{R}$ & $\mathbf{k}$ & $\mathrm{x}$ & $\mathrm{x}$ & $\begin{array}{ll}\mathrm{SO}_{2}: & \text { Pocatello }(N) \text {, Silver Valley }(R) \\
\text { TSF: } & \text { Lewiston }(N) \text {, Pocatello, Silver Valley, Soda } \\
& \text { Spring }(K)\end{array}$ \\
\hline$:$ & $\begin{array}{l}\text { Ore.. } \\
\text { Wash. }\end{array}$ & $\begin{array}{l}\mathbf{X} \\
\mathbf{R}\end{array}$ & $\begin{array}{c}C A \\
C A, R\end{array}$ & $\begin{array}{c}\mathrm{CA} \\
\mathrm{A}, \mathrm{CA}, \mathrm{R}\end{array}$ & $\begin{array}{l}\mathrm{CA} \\
\mathrm{CA}\end{array}$ & $\begin{array}{l}\mathrm{x} \\
\mathrm{x}\end{array}$ & $\begin{array}{l}\text { TSP: Seattle-Tacoma, Vancouver, Spokane, Clarkson } \\
\text { (CA), Yakima, Walla Walla, Richland (R) } \\
\text { Co: Yakima (A), Beatcle-Tacoma (CA), Spokane }\end{array}$ \\
\hline
\end{tabular}

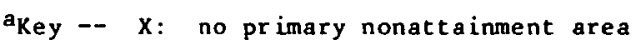

A: approved

$\mathrm{CA}$ : conditionally approved

R: submitted, under review.

$\mathrm{N}$ : not submitted

D: disapproved
}

Table 4.2 Summary of Status of Revised SIPs for Primary Nonattainment Areas, as of July 1980

\begin{tabular}{lrrrrr}
\hline & \multicolumn{5}{c}{$\begin{array}{c}\text { Number of States with } \\
\text { SIP for Pollutant }\end{array}$} \\
\cline { 2 - 7 } \multicolumn{1}{c}{ Status } & $\mathrm{SO}_{2}$ & $\mathrm{TSP}$ & $\mathrm{CO}$ & $\mathrm{O}_{3}$ & $\mathrm{NO}_{\mathbf{x}}$ \\
\hline $\begin{array}{l}\text { Approved or } \\
\text { conditionally approved }\end{array}$ & 6 & 15 & 15 & 25 & 2 \\
$\begin{array}{l}\text { Conditionally approved } \\
\quad(\text { partial) }\end{array}$ & 5 & 8 & 6 & - & - \\
$\begin{array}{l}\text { Under review } \\
\text { Not submitted }\end{array}$ & 8 & 7 & 13 & 14 & 1 \\
$\begin{array}{l}\text { Disapproved } \\
\text { Under review or not }\end{array}$ & 1 & 4 & - & 1 & - \\
$\quad$ submitted & - & 2 & 1 & 1 & - \\
Total & 4 & 3 & 3 & 2 & - \\
\hline
\end{tabular}


to be subject to sanctions -- new sources were to be banned and federal funds for highway and sewage treatment plants were to be restricted. The sanctions were imposed, at least technically, as soon as the deadline passed.

The $1 \mathrm{imit}$ on federal funds for highways required an agreement on procedures between EPA and the Department of Transportation (DOT). The two agencies published an initial proposal in the Federal Register in June 197912 and jointly promulgated a final ruling in April 1980.13 The funding limits apply to nonattainment areas for $\mathrm{CO}$ and $\mathrm{O}_{3}$ where transportation measures are needed as part of an attainment strategy. In both proposed and final rules, the EPA procedures are: (1) identify areas where an SIP with transportation measures is needed and where "reasonable efforts towards submittal" are lacking; (2) publish findings in the Federal Register 60 days later, if negotiation with the state fails; (3) allow a public comment period of 30 days; (4) notify DOT of the final ruling on federal funding limits; and (5) publish the ruling in the Federal Register. After the final ruling is published, the Federal Highway Administration will not approve any projects or award grants "... other than for safety, mass transit, and transportation projects related to air quality improvement."13 Similarly, EPA will not award any grants except for exempt activities. Whenever an EPA grant is denied, the agency will keep the grant money available for the applicant for one year.

In its first ruling, EPA decided that Colorado exhibited a lack of "reasonable effort" after the state legislature failed to pass the necessary I\&M program in Apri1, 1980. The state subsequently passed the legislation May 7, 1980, and Governor Lamm signed the bill into law on May 23. The EPA has initiated a review of the legislation as part of a revised SIP, and has begun action to rescind the sanction. No funding had actually been affected.

California's I\&M program is still incomplete. The EPA declared the program inadequate and published its finding in the Federal Register on September 8, 1980.14 This first step in the procedure to cut off federal funds established a public comment period of 45 days. The notice of proposed rulemaking comments that "if finalized, this action may impact as much as $\$ 850$ million in federal assistance for the state of California in $\mathrm{fiscal}$ year 1981."14 The public comment period was not over as of this writing.

According to the Clean Air Act Amendments, an approved, revised SIP for a nonattainment area was a "precondition for the construction or modification of any major stationary source in any such area."15 On July 2, 1979, EPA clarified that the ban would apply only, to permits submitted after June 30,1979 , for major sources of a pollutant in areas designated as nonattainment for that pollutant, and in areas where a revised SIP had not been approved or conditionally approved.16. Conditional approval would be granted only if an SIP complied substantially with the statutes and regulations. According to EPA Region $V$ staff, 17 conditional approval is recommended only if a revised SIP's new source review procedure and attainment strategy are acceptable and if deficiencies are minor. Under a conditionally approved SIP, new sources are allowed to begin construction unless an individual source is subject to a regulation that is conditional. (For example, $T S P$ plans in Iilinois and Michigan are conditionally approved, except for the iron and steel industry, for which emission limits are still being reviewed.) 
In a Federal Register promulgation of September 1980,18 EPA discussed the imposition of a ban in a nonattainment area that covers several political subdivisions. If one subdivision implemented the SIP provisions and another did not, EPA ruled that 'the new source ban would not apply to the compliant subset of a nonattainment area. Several factors limit the number of sources affected by a ban on new sources -- the review of partial SIPs, the conditional and partial approval of SIPs by EPA, the small, size of many nonattainment areas, and the ban's restriction to major sources.

As Tables 4.1 and 4.2 show, a number of revised SIPs have been conditionally approved, either wholly or in part. Conditional approval removes a new source ban, unless the conditions are not corrected by a deadline set by EPA in the ruling. Conditional or full approval for a pollutant in one area lifts the ban in that area; new source permits need not be held up until the entire state is covered by an approved SIP.

Nonattainment areas for $\mathrm{SO}_{2}$ and $\mathrm{TSP}$ are sma11, subcounty areas. (See the maps in Appendix A, for example.) Consequently, a ban on new sources of these pollutants would have 1 imited effect. Nonattainment areas for $\mathrm{O}_{3}$, however, are typically much larger. Therefore, a ban accompanying an incomplete $\mathrm{SIP}$ for $\mathrm{O}_{3}$ could have a much greater effect. on hydrocarbon (HC) sources. The ban, however, is only to be imposed on major sources of the pollutant for which the area is designated nonattainment. The definition of a major source that resulted from the Alabama Power decision (see Sec. 2.4.1) has reduced the number of sources that might be subject to a ban.

The actual impact of the statutory ban on new major sources is difficult to ascertain. State and local agencies for air pollution control revipw the permit applications; consequently, there is no central information on sources denied permits. Officials from.several states with significant portions of a revised SIP still under review or not submitted (Ohio, California, Indiana, and Pennsylvania, for example) indicated that, "to the best of their knowledge," no major source had been denied a permit as a result of the sanction: This, the officials explained, was because many applications for permits were submitted immediately before the deadline and are still under review; applications by smaller sources were deferred until the definition of source subject to review was decided; and the number of major new sources seeking to locate in a specific nonattainment area was 1 imited. In Ohio, for example, permits for several HC sources were held up by the ban that accompanied the state's incomplete $0_{3}$ plan. 11 The sources are now minor, according to the most recent definition, and are no longer subject to the ban. In general, the state agencies believe that continued failure to have an approved SIP will affect new major sources soon. In particular, one or two sources of particulate matter in Ohio and of hydrocarbons in California may have permits delayed because of the sanction.

\subsection{ATTAINMENT STRATEgIES}

\subsubsection{Sulfur Dioxide}

Our earlier, five-volume report on SIPs concluded that the $\mathrm{SO}_{2}$ attainment strategies called for: 
- Bringing stationary sources that are out of compliance into compliance with SIP emission limits. This strategy is typical of the states in Region V and VI.

- Continuing use of lower-sulfur oil in Regions I, II, and III.

- Stating the emission limits for smelters needed to bring an area into attainment. Most SIPs did not address the impact of a nonferrous smelter exemption order (Arizona, Utah, Montana, Nevada, and New Mexico).

- Requiring the new-source review procedure outlined by the 1977 amendments and EPA regulations. In most cases, the regulations are simply copied from the requirements into the $S I P$.

Additional data on SIP approaches are summarized in the following sections.

Out-of-Compliance Sources. The previous report concluded that $\mathrm{SO}_{2}$ nonattainment typically was caused by individual sources out of compliance with existing SIP emission limits. The 1977 clean Air $\Lambda$ ct Amendments established substantial penalties for noncomplying sources. The penalty was to equal the dollars a facility saved by not investing in the controls needed to achieve compliance. In July 1980, EPA announced that 150-200 major sources would incur penalties on January 1 , 1981:19 However, it is too soon to see how these fines affect compliance and attainment of $\mathrm{SO}_{2}$ standards.

Ohio raised a significant issue about methods of determining compliance. The SIP proposed a 30-day average emission limit to allow for the varying sulfur content of coal, instead of a maximum 24-hour emission limit. In February 1980, the EPA ruled on the $\mathrm{SO}_{2}$ emission limits and disapproved the 30-day average until Ohio provided technical documentation to prove that the standards would not be violated. The state subsequently submitted 37 volumes of such proof; EPA Region $V$ is still reviewing the documentation. 20

The Ohio issue on averaging time has been addressed by several EPA promulgations. In a December 1979 memo, Walt Bàrber, director of EPA's Office of Air Quality Planning. and Standards, proposed that the agency accept the state's method for calculating air quality impact. This alternative method, called expected exceedances or EX-EX, is not based on an assumption of constant, maximum emissions, but is based instead on statistical probability. The existing method assumes that the daily sulfur content of coal is always at the maximum level. In contrast, the EX-EX method takes into account daily variations in the sulfur content of a plant's coal supply and models the effect of varying emissions on air quality. Maximum allowable emissions become monthly averages under the EX-EX approach and are less restrictive than the current method.

In a Federal Register promulgation of February 1980, 21 EPA announced plans to review $\mathrm{SO}_{2}$ regulations for large coal-fired power plants. Ohio's SIP prompted EPA to review requirements for averaging time, dispersion modeling, and methods of compliance and enforcement for all power plants. An EPA contractor reviewed the EX-EX method and issued a report in August 1980.22 
Use of Clean Fuels. The states of the Northeast typically do not have nonattainment areas for $\mathrm{SO}_{2}$. They achieve attainment by using low-sulfur oil and by adopting stringent sulfur-in-fuel restrictions. As the price of oil increases and availability becomes uncertain, however, these states are reviewing $\mathrm{SIP}$ requirements for $\mathrm{SO}_{2}$.

Connecticut's SIP limits sulfur content of fuel to $0.5 \%$. Recently, the state proposed a "Btu bubble" 23 that allows a source to apply the state $1 \mathrm{imit}$ of $0.55 \mathrm{1b} \mathrm{SO}_{2} / 10^{6} \mathrm{Btu}$ to its entire energy use, rather than to each stack individually. A total allowable level of $\mathrm{SO}_{2}$ tons per year would be calculated for the facility, based on fuel consumption in 1972 ( $t$ he year the sulfur-in-fuel limit was passed). With conservation and energy management, a facility could emit up to that level, using fuels with different sulfur contents. Officials of EPA Region I have required that the emissions from any source using a Btu bubble not exceed the PSD Claba II increments. To theet this requirement, the state placed a cap of $2.2 \%$ on the sulfur content of all fuels. This Btu bubble plan, however, is not yet in effect.

Massachusetts does not have any $\mathrm{SO}_{2}$ nonattainment areas and restricts the sulfur content of fuel according to air pollution control district. State regulations, 24 however, allowed the use of higher-sulfur fuel (up to $2.2 \%$ ) in sources with heat input greater than $100 \times 10^{6} \mathrm{Btu} / \mathrm{hr}$, provided that the source received permission and that the resulting emissions would not violate any air quality regulation. Under the rule, a number of sources applied for permission to burn higher-sulfur fuel. For example, a variance for the Mt. Tom Generating Station in Holyoke was approved and one for Holyoke Gas and Electric denied, based on projected air quality impacts. 25 State regulations allowed exemptions up to July 1979. In June 1979, FPA proposed agcepting Massachuserts' request to make the variance permanent.

Similarly, Washington, D.C., has received an extensiun of the variance from the $0.5 \%$ sulfur-in-fuel regulation to $1 \% .26$ This is the chird extension Washington has received from EPA since 1976. The District wanted the sulfurin-fuel regulation changed permanently but EPA approved the variance only through December 31, 1980 .

Nonferrous Smelters. In the weatern United States, many $\mathrm{SO}_{2}$ nonattainment areas are caused by primary metal smelters that are waived from compliance with SIP emission limits. The 1977 Clean Air Act Amendments authorized EPA to issue nonferrous smelter orders (NSOs) that allowed the ailing industry to delay compliance until 1983, with an option for an extension through 1988. In June 1980,27 EPA promulgated rules for initial NSOs with January 1, 1983, as the deadiine for compliance. The EPA has not yet developed rules to extend the deadline for compliance to January 1988. According to EPA, a smelter would be allowed to use interim controls and dispersion techniques (such as reduced operations when atmospheric conditions inhibit dispersal of emissions) to maintain the national standards instead of complying with SIP emission limits.

In Idaho, for example, an $\mathrm{SO}_{2}$ nonattainment area surrounds a lead and zinc smelter in Shoshone County. The SIP projected, the area would reach attainment in 1980, when the smelter was required to meet emission limits. Although the smelter is expected to receive an NSO, the NSO should not delay the area's attainment of the standards. 
Copper smelters in Arizona are the primary cause of $\mathrm{six} \mathrm{SO}_{2}$ nonattainment areas. The state has proposed a new method for calculating maximum $\mathrm{SO}_{2}$ emissions from the smelters. The new method, called multipoint rollback (MPR), is analogous to the EX-EX method proposed for calculating $\mathrm{SO}_{2}$ emission limits for power plants. The current method for determining maximum emission rates for a smelter uses a single point and the worst meteorological conditions. Multipoint rollback is based on a statistical distribution of emissions that recognizes the variability of smelter operations. Using a year of actual air quality data, MPR determines an overall emission 1 imit that allows a number of short-term exceedances of a single point limit. The EPA Region IX staff 28 said this model is being discussed at EPA headquarters. Arizona has withdrawn its SIP, pending the outcome of these discussions.

\subsubsection{Total Suspended Particulates}

Our previous report said that SIPs for TSP nonattainment areas included the following attainment strategies:

- Designate rural areas as attainment on the basis of the rural fugitive dust exemption;

- Draw all nonattainment areas as small as EPA will accept;

- Retain current SIP emission limits on particulate matter from stacks;

- Require RACT on fugitive industrial emissions;

- Develop controls for nontraditional sources of fugitive dust in urban areas; and

- Request an 18-month extension of the deadline for submitting a revised SIP for the secondary st and ards.

An update of changes in attainment strategies follows.

Fugitive Dust Exemption. A number of SIPs proposed some nonattainment areas be redesignated under the rural fugitive dust exemption. (See Sec. 2.4.3.) Iowa, for example, proposed that four areas be redesignated on the premise that dust from agricultural activity and unpaved roads caused the violations. The EPA agreed and redesignated these areas as nonattainment for the secondary TSP standard. Texas, Oklahoma, and several arid western states (e.8., Nevara and Arizona) included similar fugitive dust. exemptions in their SIPs. The potential loss of this exemption will greatly increase the exleat of TSP nonattainment.

$\therefore$

$\because \because \quad$ Control of Nontraditional Sources. Although most SIPs for urban TSP nonattainment areas included plans to develop controls for fugitive dust from nontraditional sources, little progress has been made. However, EPA is planning to fund three demonstration projects of nontraditional particulate control in Portland, Oregon; Denver, Colorado; and Minneapolis/St. Paul, Minnesota.29 Even more basic is a recent effort to estimate what percentage 
of urban particulates come from nontraditional sources. 30 . This study, based on 1975 data collected in Pittsburgh, estimated that a $25 \%$ decrease in annual traffic flow could cause a $20 \%$ decrease in annual average particulates. The study did not predict effects on the short-term TSP average, the standard most 1 ikely to be violated. It seems that TSP attainment will be difficult to achieve, especially in urban areas where nontraditional sources must be controlled.

\subsubsection{Nitrogen Dioxide}

The three $\mathrm{NO}_{2}$ nonattainment areas planned to achieve attainment by:

- Relying on increased controls on motor vehicles required to attain the $\mathrm{O}_{3}$ and $\mathrm{CO}$ standards; and

- Studying possible controls for stationary sources.

No areas have been redesignated and no new information on attainment strategies is available.

\subsubsection{Ozone and Carbon Monoxide}

The SIPs for these two transportation-related pollutants provided for:

- RACT on stationary sources;

- Transportation control measures that rely heavily on the reductions projected to resule from the Federal Motor Vehicle Control Program; and

- Inspection and maintenance programs for motor vehicles in the 29 otates requesting extension to 1987.

Since our earlier report, many $\mathrm{O}_{3}$ nonattainment areas have been redesignated to attainment of the newer, less stringent standard. New attainment strategies have focused on inspection and maintenance programs. 


\section{REFERENCES}

1. Garvey, D.B., and D.G. Streets, In Pursuit of Clean Air: A Data Book of Problems and Strategies at the State Level, Argonne National Laboratory Report ANL/EES-TM-90, Vols. 1-5 (Feb. 1980).

2. 44 FR 67182, SIPs: General Preamble for Proposed Rulemaking on Approval of Plan Revisions for Nonattainment Areas -- Supplement (on the Aftermath of the Granting of Conditional Approvals for SIPs) (Nov. 23, 1979).

3. Bureau of National Affairs, Current Developments, Environment Reporter, p. 10 (May 2, 1980).

4. 44 FR 65687, Guide to Data Collection for 1982 SIP Revisions (Nov. 14, 1979).

5. U.S. Environmental Protection Agency, memo from Michael James to Richard Rhoads (Oct. 7, 1980).

6. U.S. District Court of Appeals for District of Columbia 非8-1006, Alabama Power Co. et al. vs. D.M. Costle, U.S. Environmental Protection Agency, et al.

7. 45 FR 52676, Requirements for Preparation, Adoption and Submittal of Implementation Plans: Approval and Promulgation of Implementation Rules (Aug. 7, 1980).

8. Inside EPA, p. 3 (June 20, 1980).

9. 43 FR 8962, NAAQS: States Attainment Status (March 3, 1978).

10. Bureau of National Affairs, Current Developments, Environment Reporter, p. 23 (June 13, 1980).

11. Ohio Environmental Protection Agency staff, personal communication (Nov. 13, 1980).

12. 44 FR 33473; EPA Proposed Policy and Procedure for Applying Transportation Funding Limits (June 11, 1979).

13. 45 FR 24692, Federal Assistance Limitation Required by Section 176(a) of the Clean Air Act: Final Policy and Procedures (April 10, 1980).

14. 45 FR 59180, Federal Assistance Limitations, State of California (Sept. 8, 1980).

15. Clean Air Act Amendments of 1977, P.L. 95-95, Section 172(a)(1).

16. 44 FR 38471, Statutory Restrictions on New Sources for Nonattainment Areas (July 2, 1979).

17. U.S. Environmental Protection Agency, Region V staff, personal communication (Nov. 10, 1980). 
18. 45 FR 62850, Approval and Promulgation of Implementation Plans: Statutory Restrictions on New Sources Under Certain Circumstances for Nonattainment Areas (Sept. 22, 1980).

19. Inside EPA (Ju1y 18, 1980).

20. U.S. Environmental Protection Agency, Region V staff, personal communication (Aug. 8, 1980).

21. 45 FR 9994, Regulation of Large Coal-Fired Boilers for $\mathrm{SO}_{2}$ Emissions $\because$ (Feb. 14, 1980).

22. U.S. Environmental Protection Agency, The ExEx Method: Incorporating Variability in Sulfur Dioxide Emissions into Power Plant Impact Assessment, prepared by SAI Inc. (Aug. 13, 1980).

23. Bureau of National Affairs, Current Developments, Environment Reporter, p. 1925 (Feb. 4, 1980).

24. State of Massachusetts, Air Pollution Control Regulations, Section 7.05 .

25. 44 FR 37513, Approval and Promulgation of Implementation Plans: Massachusetts; Proposed Rulemaking Governing the Burning of Higher Sulfur Fuel in Four Air Pollution Control Districts (June 27, 1.979).

26. 45 FR 1024, Approval and Promulgation of Implementation Plans: District of Columbia; Proposed Rulemaking Governing the. Burning of Higher Sulfur Fue 1. (Jan. 4, 1980).

27. 45 FR 42514, Primary Nonferrous Smelter Orders: National Rules (June 24, $1980)$.

28. U.S. Environmental Protection Agency, Region IX staff, personal communication (Nov. 7, 1980).

29. Bureau of National Affairs, Current Developments, Environment Reporter (July 11, 1980).

30. Lincoln, David R., and E.S. Rubin, Contribution of Mobile Sources to Ambient Particulate Concentrations in a Downtown Urban Area, J. of Air Pollution Control Assn. 30(7):777 (July 1980). 
APPENDIX A

1

MAPS OF DESIGNATED NONATTAINMENT AREAS

AS OF JULY 1, 1980 
THIS PAGE

\section{WAS INTENTIONALLY LEFT BLANK}


APPENDIX A

MAPS OF DESIGNATED NONATTAINMENT AREAS AS OF JULY 1, 1980

The states typically designated smal1, subcounty areas as nonattainment for all pollutants except ozone. The usual method of displaying nonattainment areas. as counties containing designated areas overstates the extent of nonattainment. To be more precise, the five-volume report included maps of the actual subcounty areas. This appendix contains new maps that update nonattainment areas and include any redesignations that have been promulgated in the Federal Register as of July 1, 1980. In addition, the state summaries of discrete nonattainment areas that appeared in the five-volume report have been updated to accompany the maps. Florida ( $\mathrm{CO}$ ), North Carolina (TSP), and Washington $\left(\mathrm{SO}_{2}\right)$ each had a single nonattainment area for the specified pollutant. Those areas have been redesignated as unclassified or attainment; therefore, maps are not necessary for the 1980 update. The state summaries, however, are included. 
Table A.1 California: Air Quality. Summary

\begin{tabular}{|c|c|c|c|}
\hline \multirow[b]{2}{*}{ Pollutant } & \multirow{2}{*}{$\begin{array}{l}\text { St andard } \\
\text { Averaging } \\
\text { Period }\end{array}$} & \multicolumn{2}{|c|}{$\begin{array}{c}\text { No. of Discrete } \\
\text { Nonattainment Areas a }\end{array}$} \\
\hline & & Primary & Second ary \\
\hline $\mathrm{SO}_{2}$ & $\begin{array}{r}24 \mathrm{hr} \\
1 \mathrm{yr}\end{array}$ & 1 & 0 \\
\hline TSP & $\begin{array}{r}24 \mathrm{hr} \\
1 \mathrm{yr}\end{array}$ & 5 & 6 \\
\hline $\mathrm{NO}_{\mathbf{x}}$ & $1 \mathrm{yr}$ & 1 & - \\
\hline CO & $8 \mathrm{hr}$ & 5 & - \\
\hline $0_{3}$ & $1 \mathrm{yr}$ & $1 / 2$ state & - \\
\hline
\end{tabular}

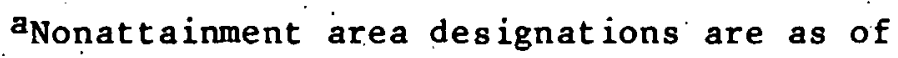
Juily 1, 1980. 


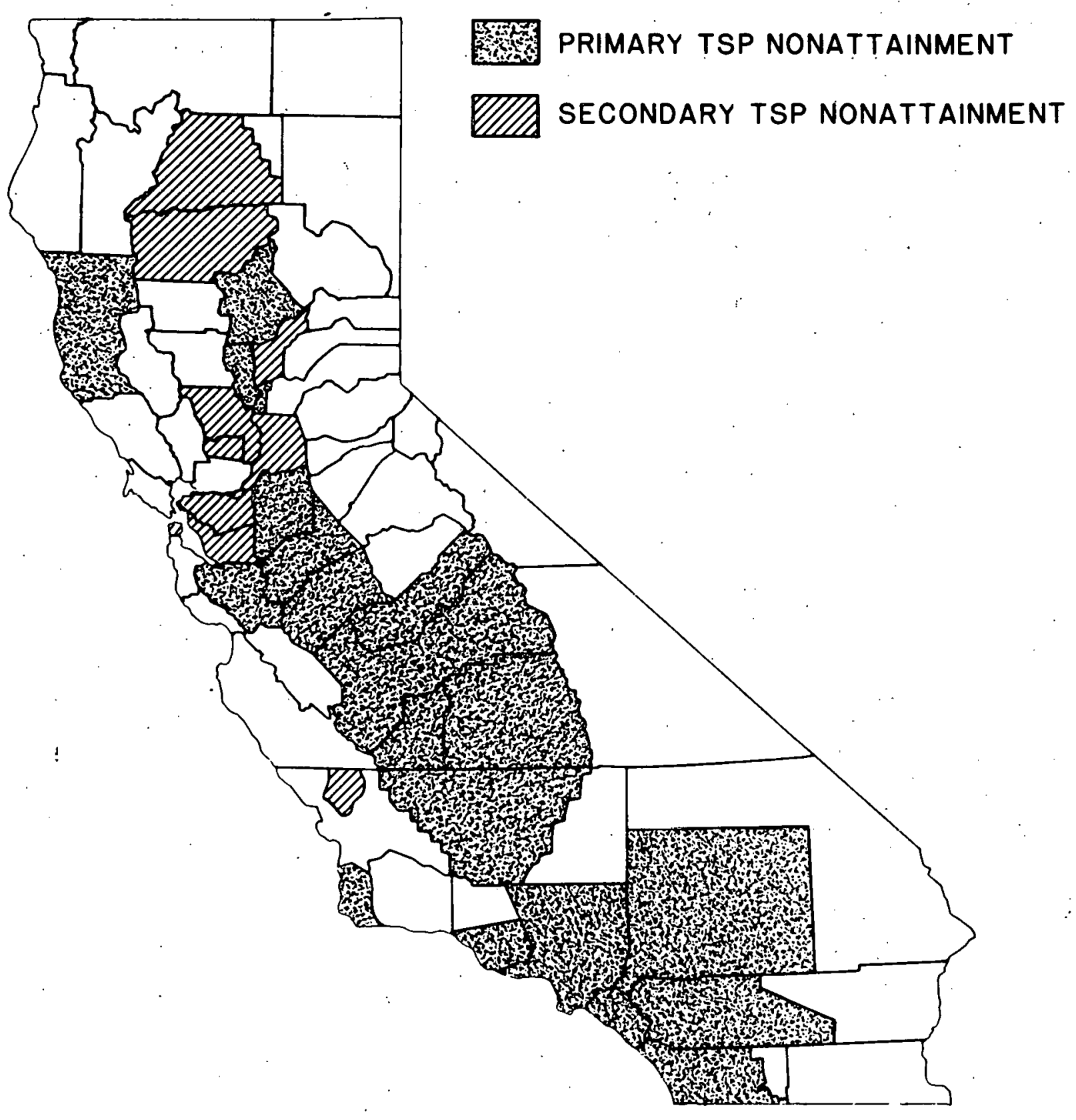

Fig. A.l California: Areas Designated as Primary and Secondary TSP Nonattainment as of July 1980 


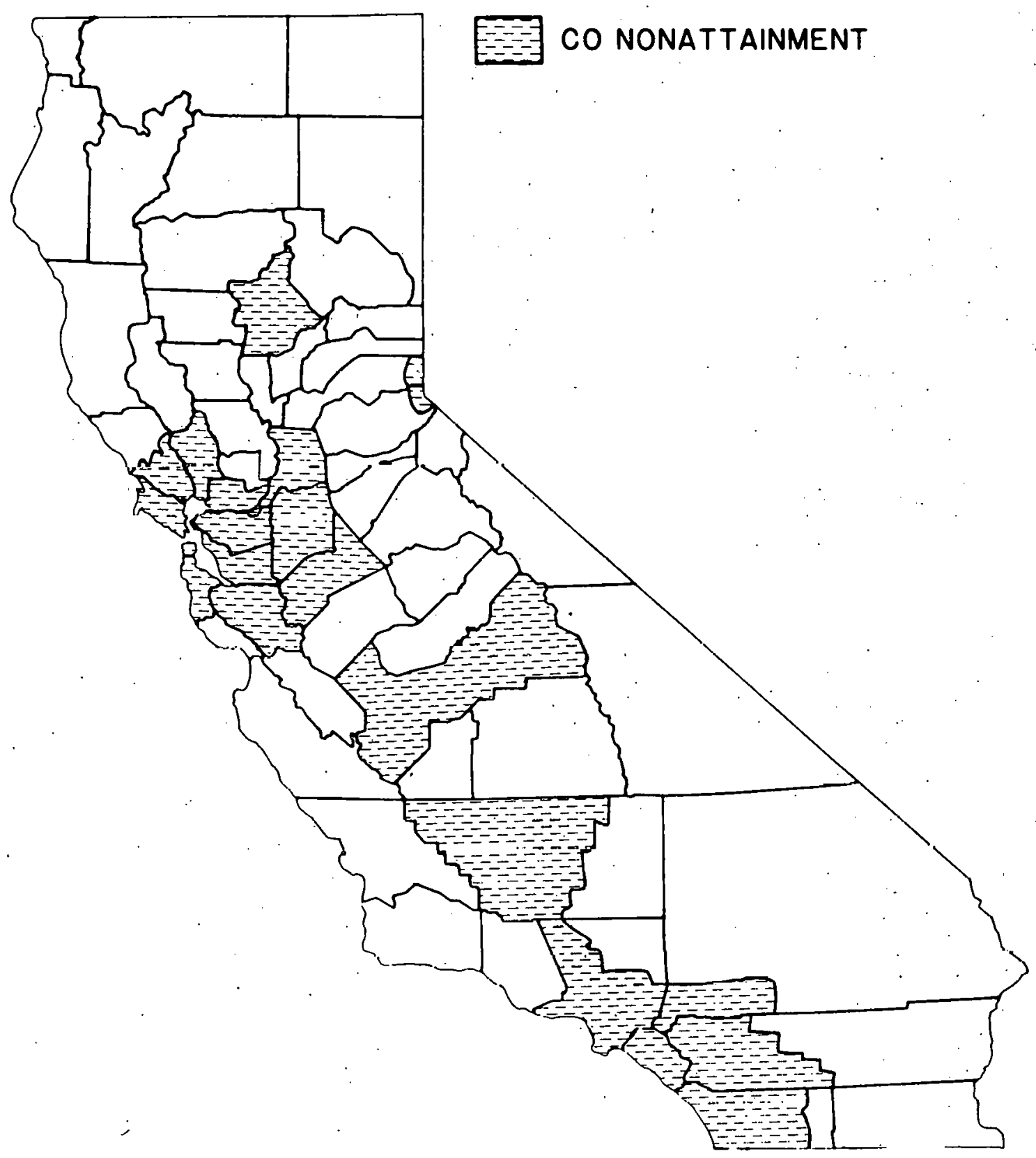

Fig. A.2 California: Areas Designated as Co Nonattainment as of July 1980 
Table A.2 Colorado: Air Quality Summary

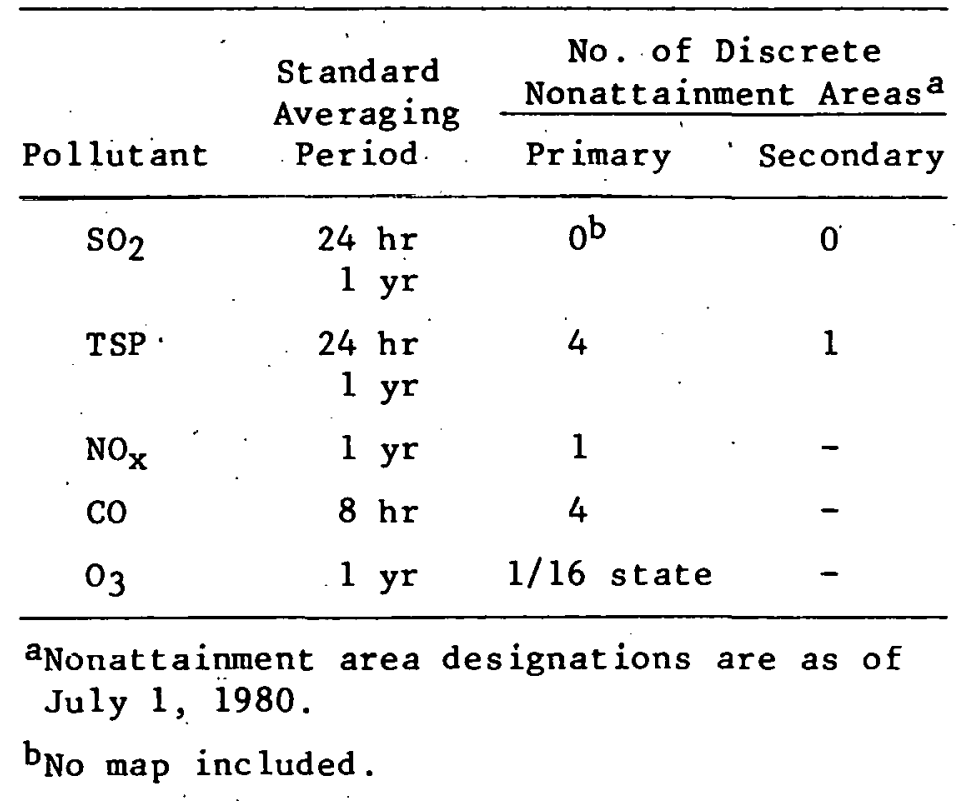




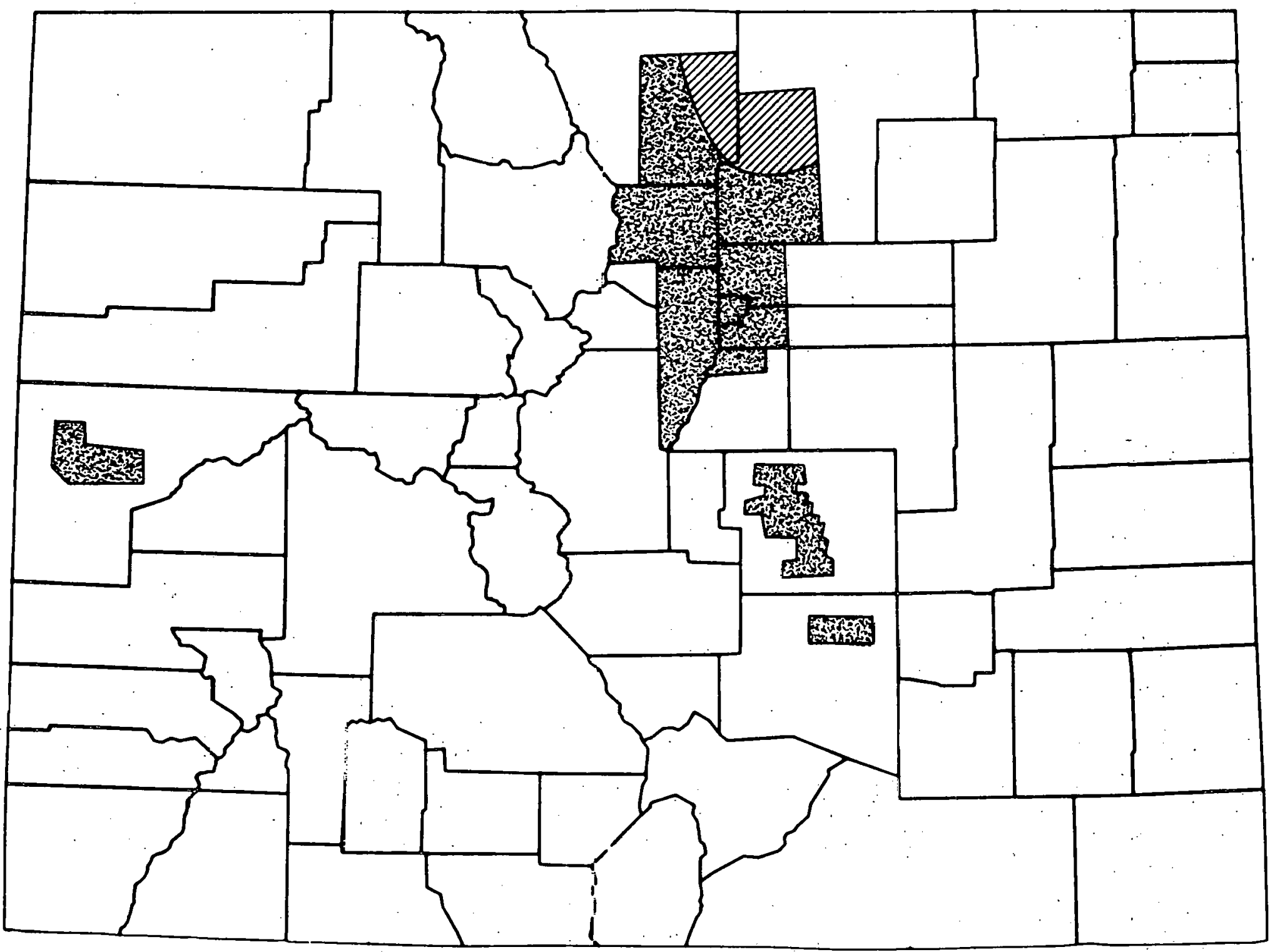

Fig. A.3 Colorado: Areas Designated as Primary and Secondary TSP Nonattainment as of July 1980 
DO NONATtainMENT

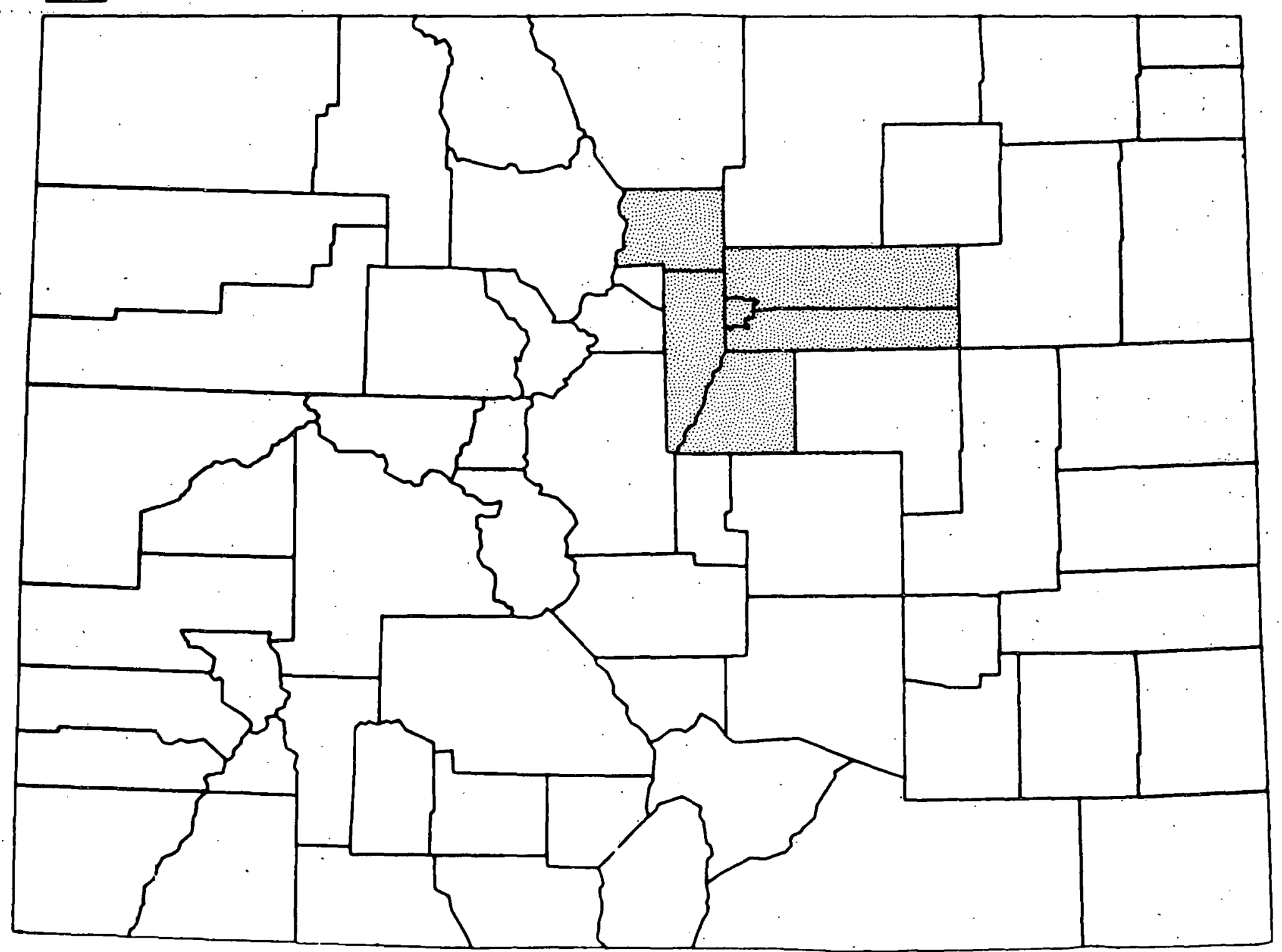

Fig. A.4 Colorado: Areas Designated as $\mathrm{O}_{3}$ Nonattainment as of July 1980 
Table A.3 Florida: Air Quality Summary

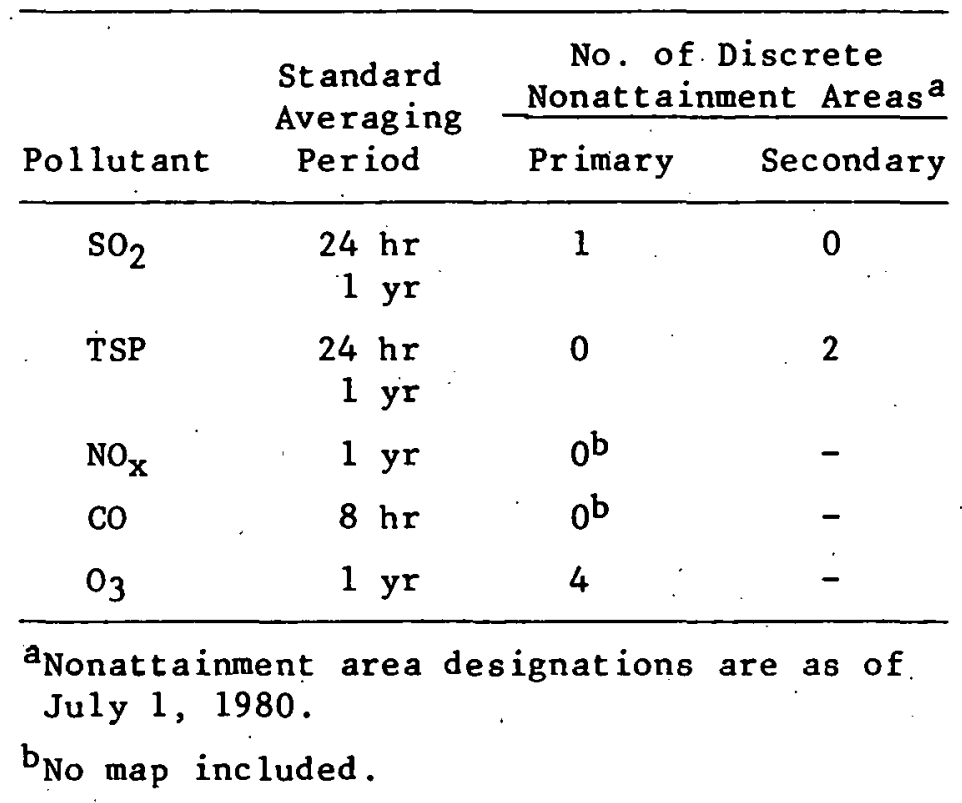




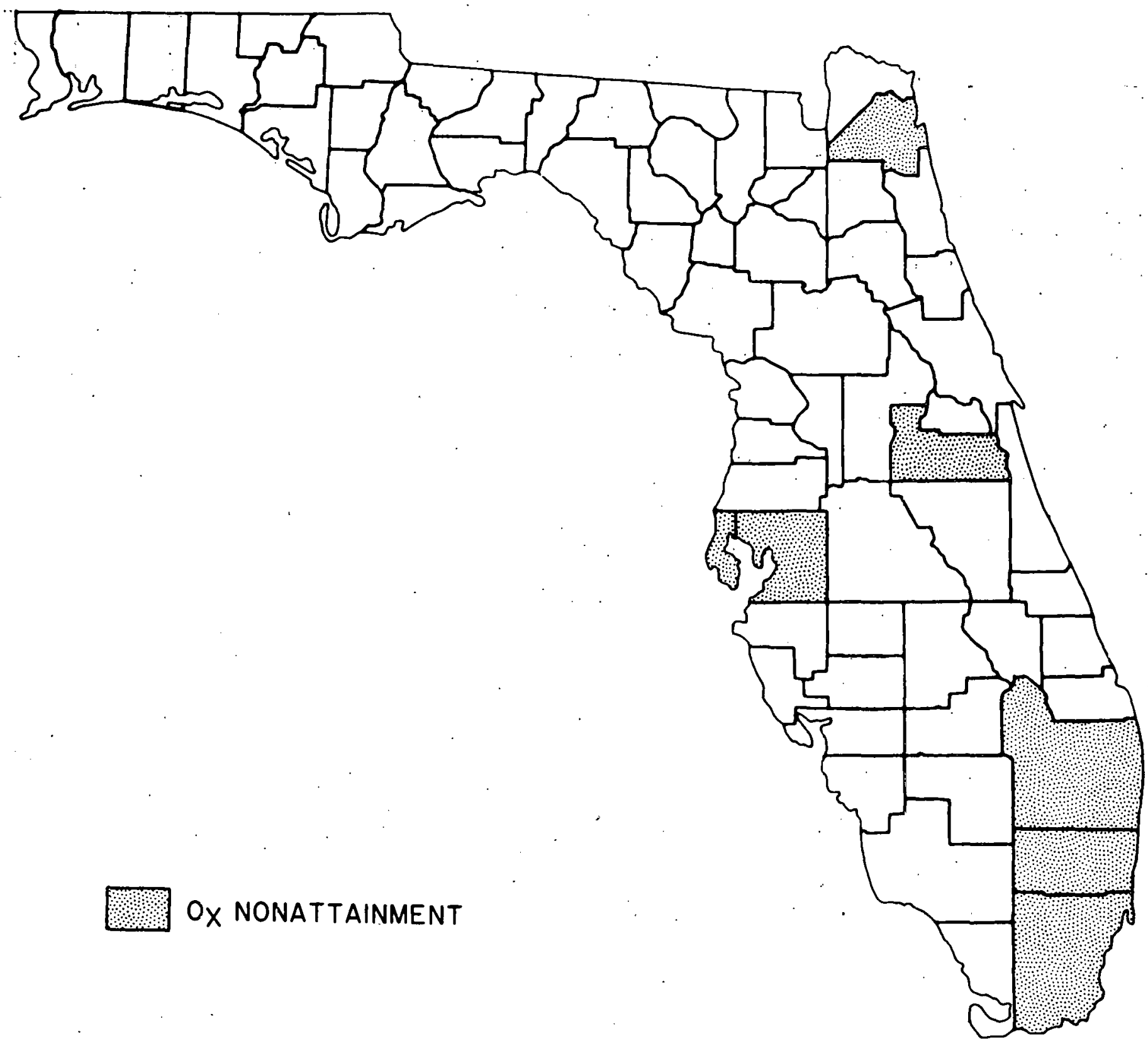

Fig. A.5 Florida: Areas Designated as $O_{3}$ Nonattainment as of July 1980 
Table A.4 Georgia: Air Quality Summary

\begin{tabular}{|c|c|c|c|}
\hline \multirow[b]{2}{*}{ Pollutant } & \multirow{2}{*}{$\begin{array}{l}\text { Standard } \\
\text { Averaging } \\
\text { Period }\end{array}$} & \multicolumn{2}{|c|}{$\begin{array}{c}\text { No. of Discrete } \\
\text { Nonattainment Areas } \\
\end{array}$} \\
\hline & & Primary & Second a ry \\
\hline $\mathrm{SO}_{2}$ & $\begin{aligned} 24 \mathrm{hr} \\
1 \mathrm{yr}\end{aligned}$ & $0^{b}$ & 0 \\
\hline TSP & $\begin{aligned} 24 \mathrm{hr} \\
1 \mathrm{yr}\end{aligned}$ & 3 & 0 \\
\hline $\mathrm{NO}_{\mathrm{x}}$ & $1 \mathrm{yr}$ & $0^{b}$ & - \\
\hline $\mathrm{CO}$ & $8 \mathrm{hr}$ & 1 . & - \\
\hline $0_{3}$ & 1 yr & 2 & - \\
\hline
\end{tabular}

a Nonattainment area designations are as of July 1, 1980.

$\mathrm{b}_{\text {No }}$ map included: 


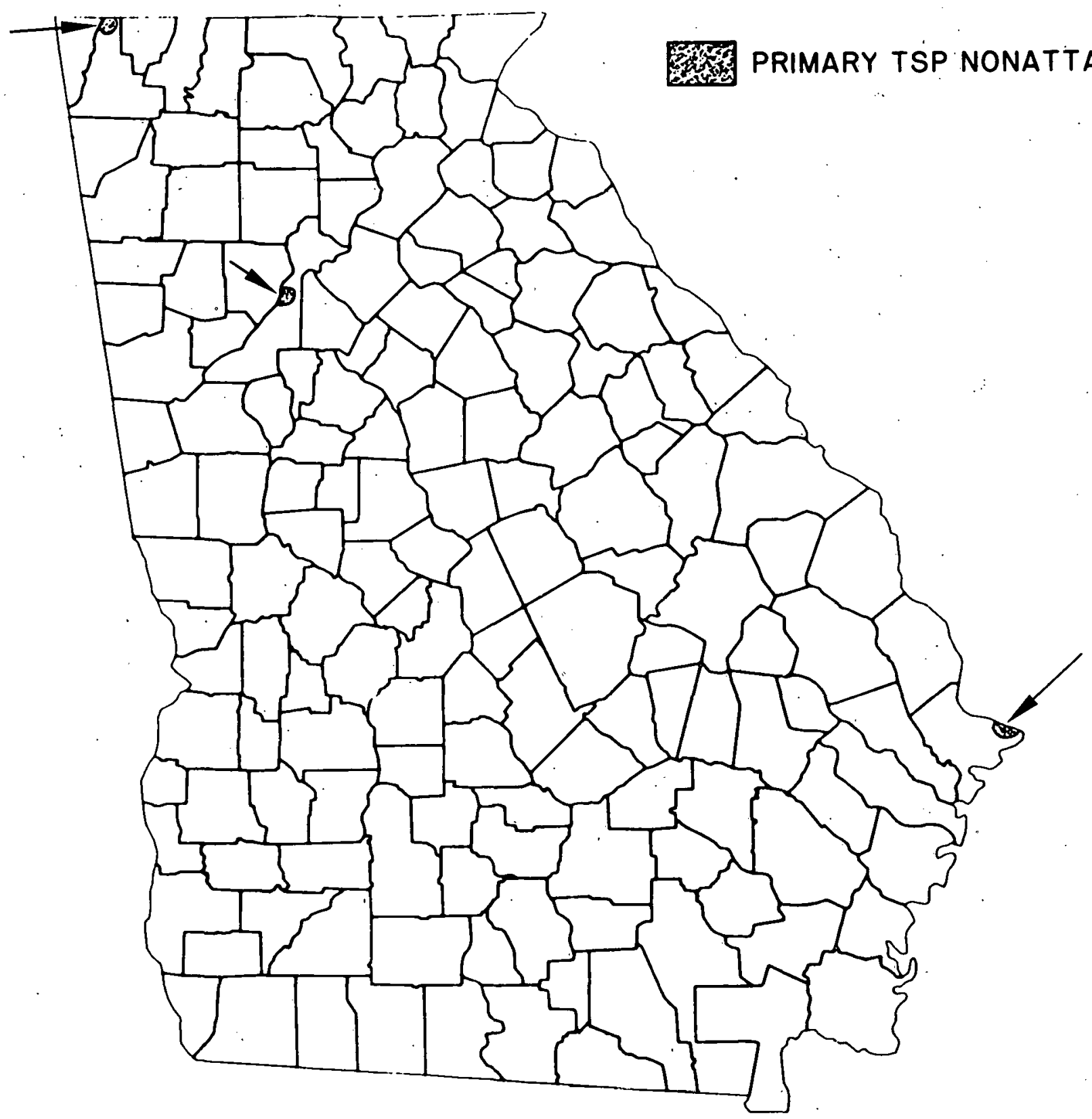

Fig. A.6 Georgia: Areas Designated as Primary TSP Nonattainment as of July 1980 
Table A.5 Illinois: Air Quality Summary

\begin{tabular}{|c|c|c|c|}
\hline \multirow[b]{2}{*}{ Pollutant } & \multirow{2}{*}{$\begin{array}{l}\text { St andard } \\
\text { Averaging } \\
\text { Period }\end{array}$} & \multicolumn{2}{|c|}{$\begin{array}{c}\text { No. of Discrete } \\
\text { Nonattainment Areas }\end{array}$} \\
\hline & & Primary & Secondary \\
\hline $\mathrm{SO}_{2}$ & $\begin{array}{r}24 \mathrm{hr} \\
1 \mathrm{yr}\end{array}$ & 2 & 0 \\
\hline TSP. & $\begin{array}{r}24 \mathrm{hr} \\
1 \mathrm{yr}\end{array}$ & 8 & 24 \\
\hline $\mathrm{NO}_{\mathbf{x}}$ & $1 \mathrm{yr}$ & 1 & - \\
\hline Co & $8 \mathrm{hr}$ & 2 & - \\
\hline$o_{3}$ & $1 . \mathrm{yr}$ & 7 & - \\
\hline
\end{tabular}

$a_{\text {Nonattainment area designations are as of }}$ Ju1y 1, 1980. 


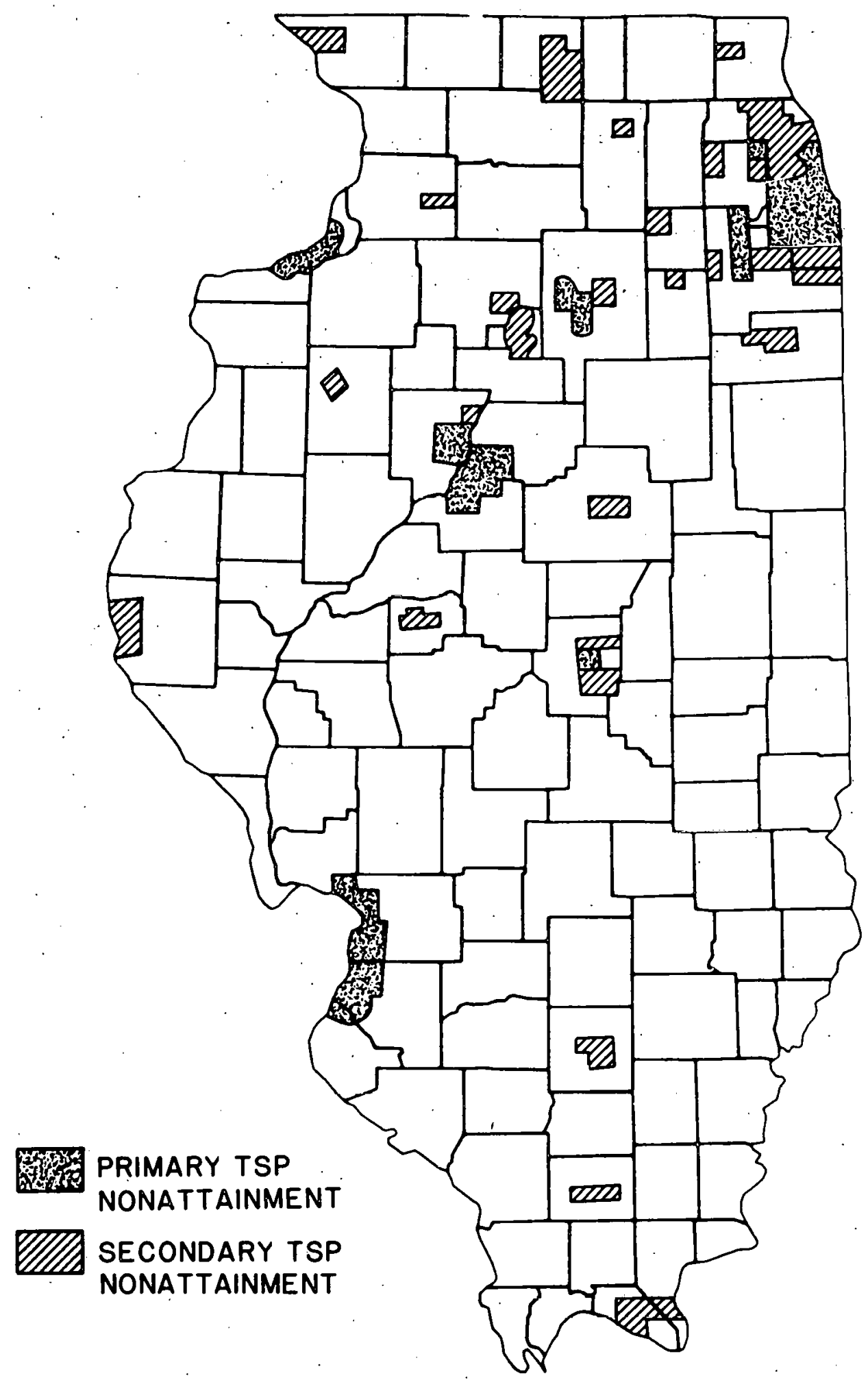

Fig. A.7 Illinois: Areas Designated as Primary and Secondary TSP Nonattainment as of July 1980 


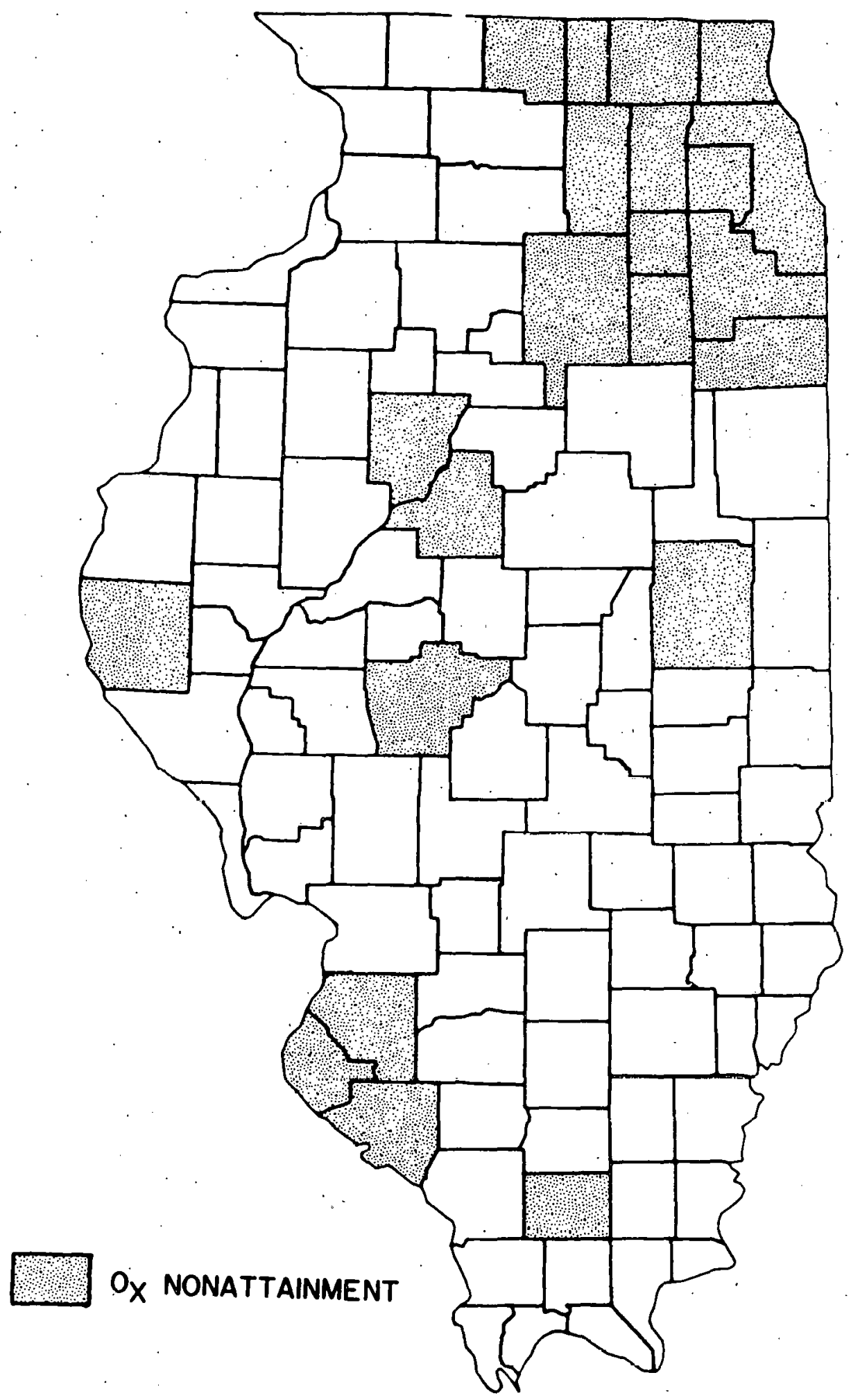

Fig. A.8 Illinois: Areas Designated as $0_{3}$ Nonattainment. as of July 1980 
Table A.6 Iowa: Air Quality Summary

\begin{tabular}{|c|c|c|c|}
\hline \multirow[b]{2}{*}{ Pollutant } & \multirow{2}{*}{$\begin{array}{l}\text { St and ard } \\
\text { Averaging } \\
\text { Period }\end{array}$} & \multicolumn{2}{|c|}{$\begin{array}{l}\text { No. of Discrete } \\
\text { Nonattainment Areas }\end{array}$} \\
\hline & & Primary & Second ary \\
\hline $\mathrm{SO}_{2}$ & $\begin{aligned} 24 \mathrm{hr} \\
1 \mathrm{yr}\end{aligned}$ & 1 & 0 \\
\hline TSP & $\begin{aligned} 24 \mathrm{hr} \\
1 \mathrm{yr}\end{aligned}$ & 4 & 6 \\
\hline $\mathrm{NO}_{\mathbf{x}}$ & $1 . \mathrm{yr}$ & $0^{b}$ & - \\
\hline $\mathrm{CO}$ & $8 \mathrm{hr}$ & 1 & - \\
\hline $\mathrm{O}_{3}$ & $1 \mathrm{yr}$ & 1 & - \\
\hline $\begin{array}{l}\text { a Nonattai } \\
\text { July } 1\end{array}$ & $\begin{array}{l}\text { nt area } \mathrm{d} \\
0 .\end{array}$ & gnation & re as of \\
\hline
\end{tabular}




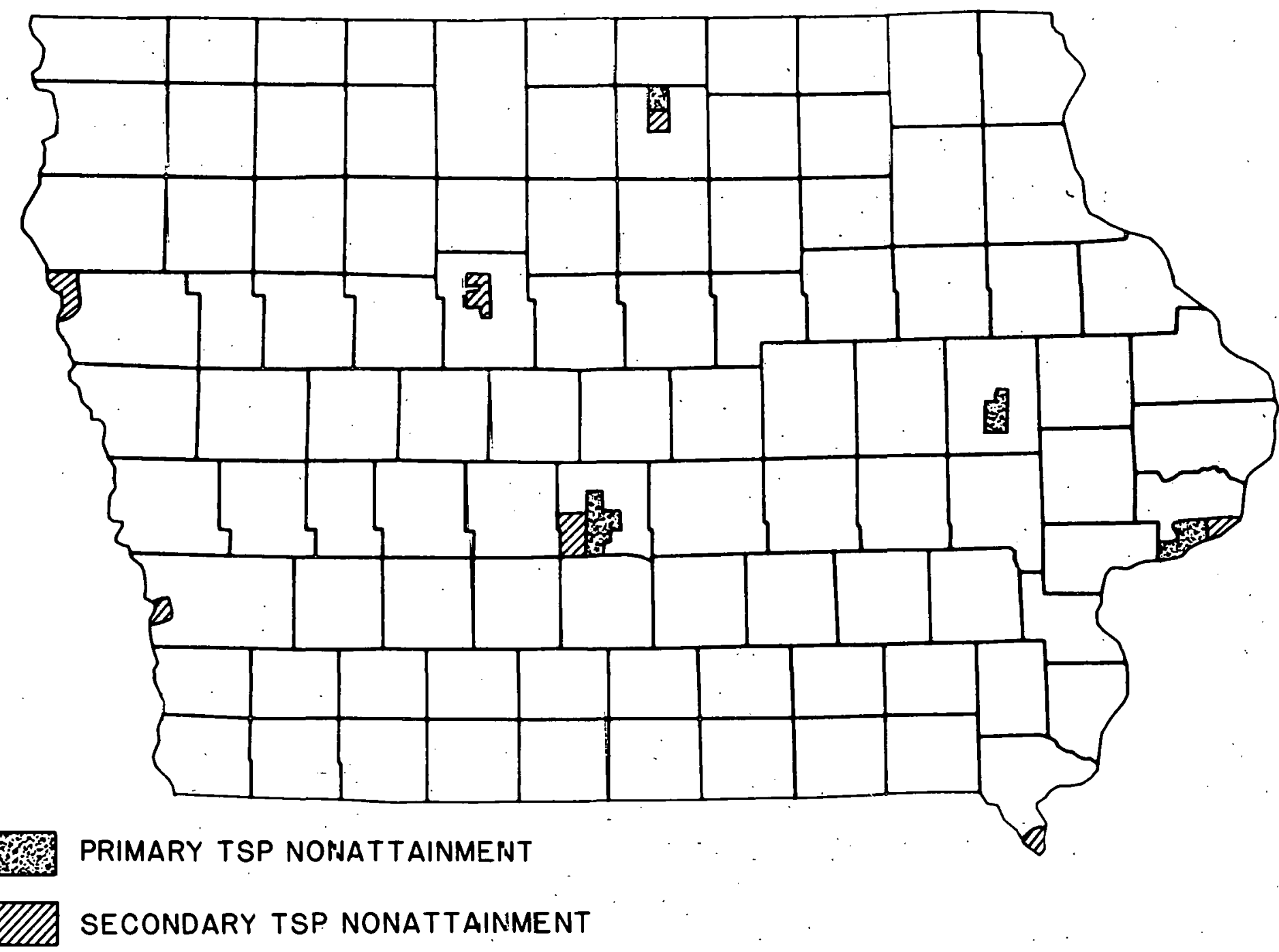

Fig. A.9 Iowa: Areas Designated as Primary and Secondary TSP Nonattainment as of July 1980 


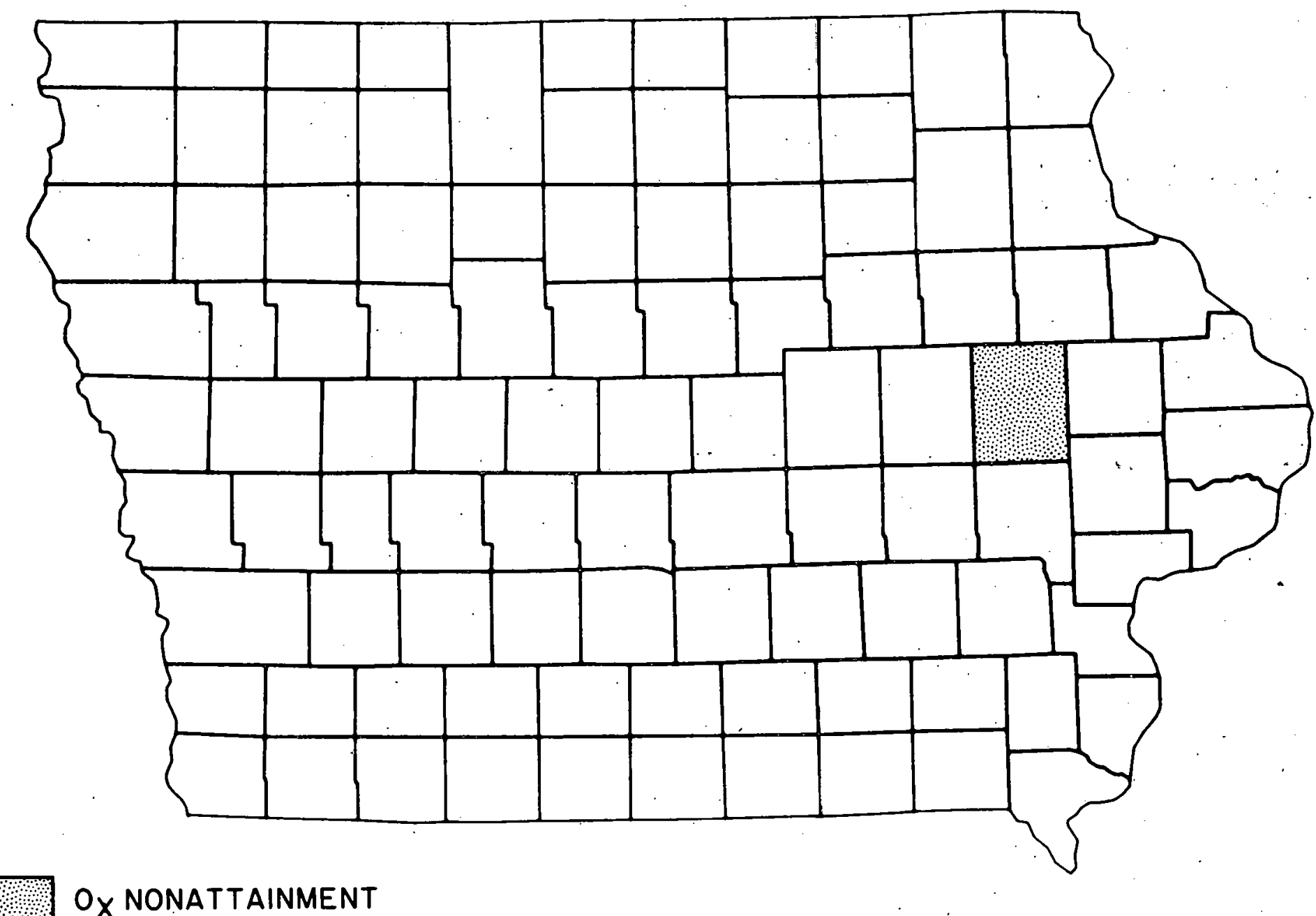

Fig. A.10 Iowa: Areas Designated as $0_{3}$ Nonattainment as of July 1980 
Table A.7 Kentucky: Air Quality Summary

\begin{tabular}{|c|c|c|c|}
\hline \multirow[b]{2}{*}{ Pollutant } & \multirow{2}{*}{$\begin{array}{l}\text { St andard } \\
\text { Averaging } \\
\text { Period }\end{array}$} & \multicolumn{2}{|c|}{$\begin{array}{c}\text { No. of Discrete } \\
\text { Nonattainment Areas }\end{array}$} \\
\hline & & Primary & Secondary \\
\hline $\mathrm{SO}_{2}$ & $\begin{aligned} 24 \mathrm{hr} \\
1 \mathrm{yr}\end{aligned}$ & 7 & 0 \\
\hline TSP & $\begin{array}{r}24 \mathrm{hr} \\
1 \mathrm{yr}\end{array}$ & 13 & 1 \\
\hline $\mathrm{NO}_{\mathbf{x}}$ & $1 \mathrm{yr}$ & $0^{b}$ & - \\
\hline CO & $8 \mathrm{hr}$ & 1 & - \\
\hline $0_{3}$ & $1 \mathrm{yr}$ & 5 & - \\
\hline
\end{tabular}




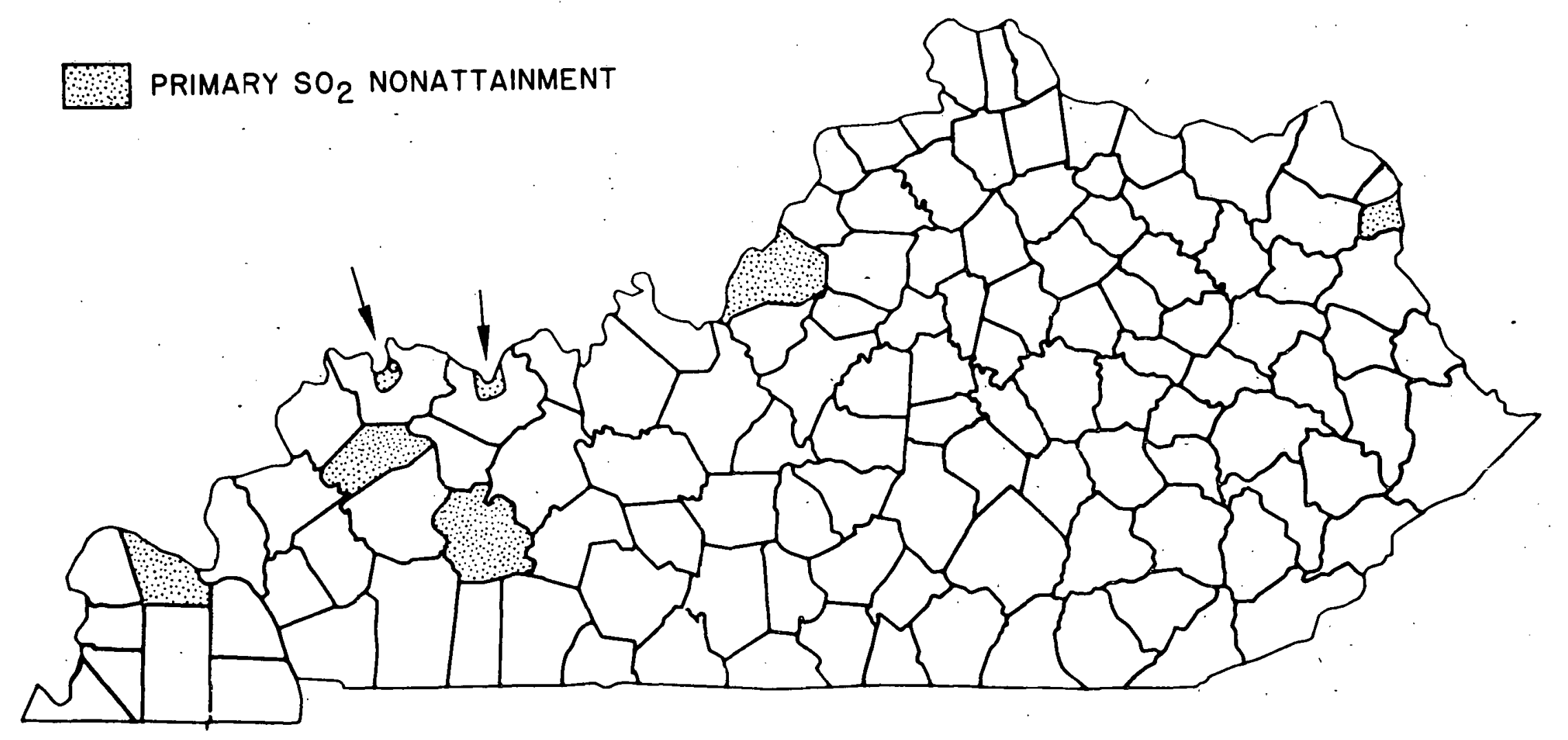

Fig. A.11 Kentucky: Areas Designated as Primary $\mathrm{SO}_{2}$ Nonattainment as of July 1980 


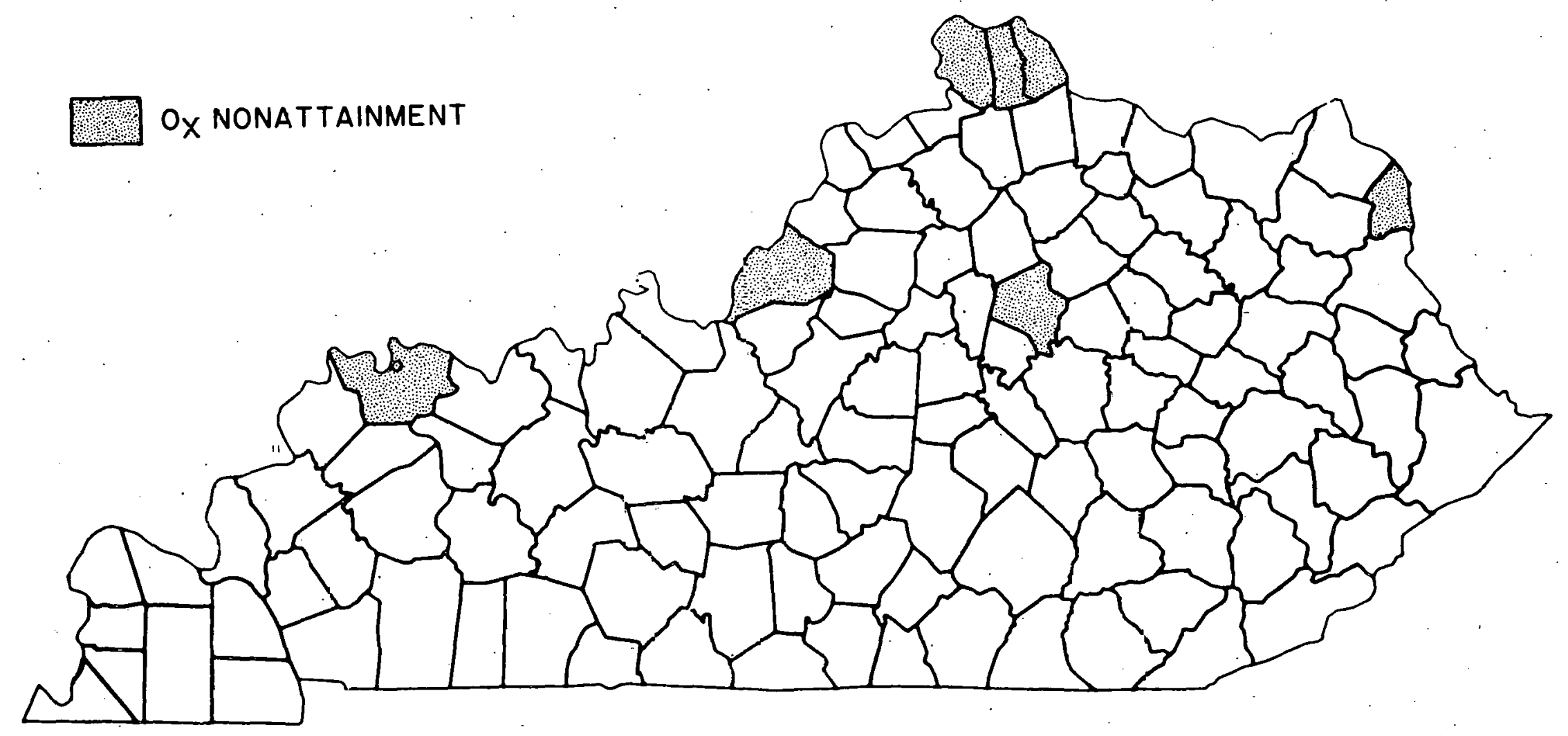

Fig. A.12 Kentucky: Areas Designated as $0_{3}$ Nonattainment as of July 1980 
Table A.8 Maine: Air Quality Summary

\begin{tabular}{|c|c|c|c|}
\hline \multirow[b]{2}{*}{ Pollut ant } & \multirow{2}{*}{$\begin{array}{l}\text { St andard } \\
\text { Averaging } \\
\text { Period. }\end{array}$} & \multicolumn{2}{|c|}{$\begin{array}{c}\text { No. of Discrete } \\
\text { Nonattainment Areas }\end{array}$} \\
\hline & & Primary & Secondary \\
\hline $\mathrm{SO}_{2}$ & $\begin{aligned} 24 \mathrm{hr} \\
1 \mathrm{yr}\end{aligned}$ & 1 & 0 \\
\hline TSP & $\begin{aligned} 24 \mathrm{hr} \\
1 \mathrm{yr}\end{aligned}$ & 0 & 3 \\
\hline $\mathrm{NO}_{\mathrm{x}}$ & $1 \mathrm{yr}$ & $0^{\mathrm{b}}$ & - \\
\hline CO & $8 \mathrm{hr}$ & 2 & - \\
\hline $\mathrm{O}_{3}$ & $1 \mathrm{yr}$ & $1 / 4$ state & - \\
\hline
\end{tabular}


56

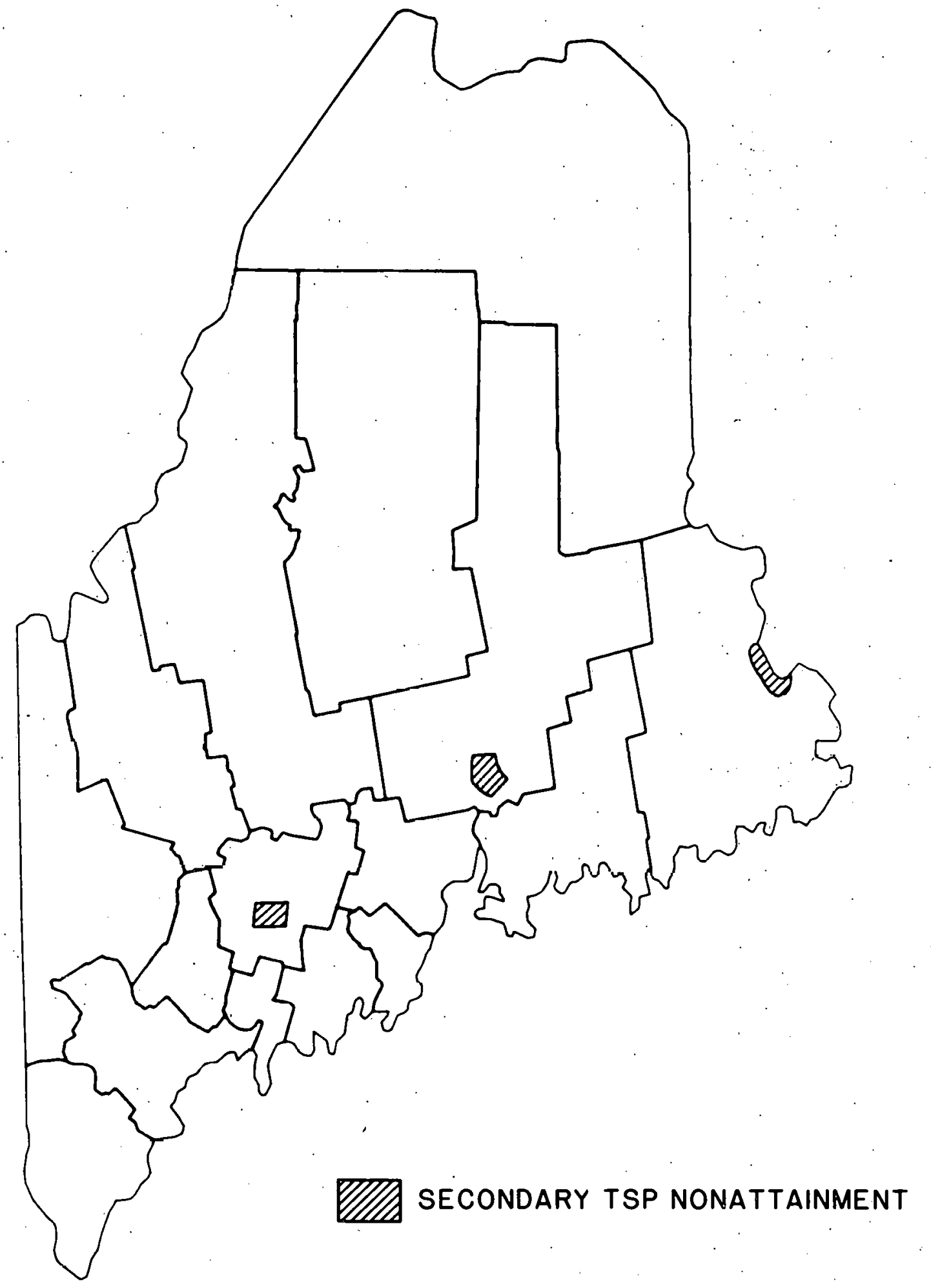

Fig. A.13 Maine: Areas Designated as Secondary TSP Nonattainment as of July 1980 
57

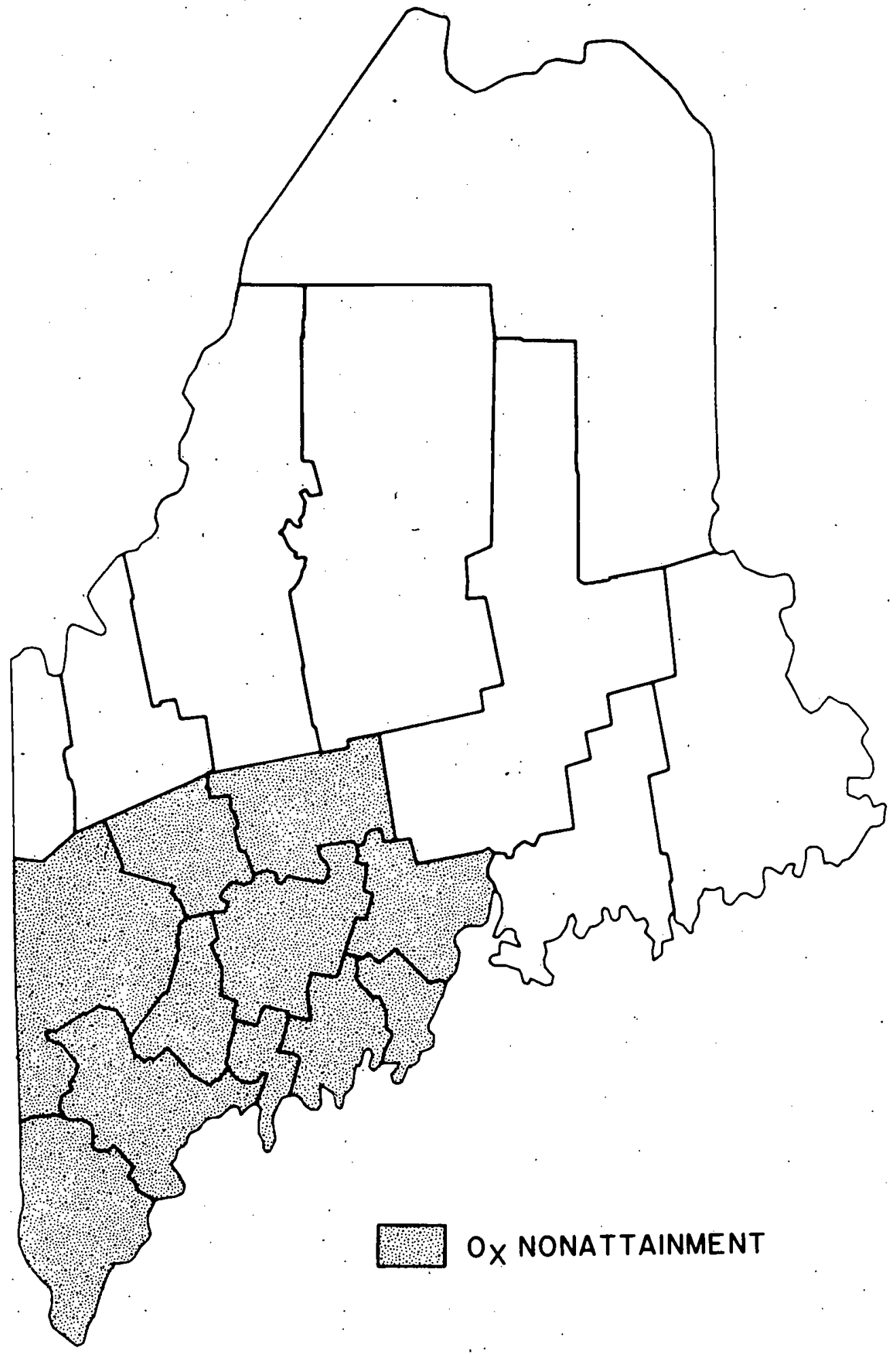

Fig. A.14 Maine: Areas Designated as $\mathrm{O}_{3}$ Nonattainment as of July 1980 
Table A.9 Missouri: Air Quality Summary

\begin{tabular}{|c|c|c|c|}
\hline \multirow[b]{2}{*}{ Pollutant } & \multirow{2}{*}{$\begin{array}{l}\text { St andard } \\
\text { Averaging } \\
\text { Period }\end{array}$} & \multicolumn{2}{|c|}{$\begin{array}{c}\text { No. of Discrete } \\
\text { Nonattainment Areas } \\
\end{array}$} \\
\hline & & Primary & Secondary \\
\hline $\mathrm{SO}_{2}$ & $\begin{aligned} 24 \mathrm{hr} \\
1 \mathrm{yr}\end{aligned}$ & 1 & 0 \\
\hline TSP & $\begin{array}{r}24 \mathrm{hr} \\
1 \mathrm{yr}\end{array}$ & 4 & $5:$ \\
\hline $\mathrm{NO}_{\mathbf{x}}$ & $1 \mathrm{yr}$ & $0^{\mathrm{b}}$ & - \\
\hline $\mathrm{CO}$ & $8 \mathrm{hr}$ & 1 & - \\
\hline 0.3 & $1 \mathrm{yr}$ & 2 & - \\
\hline $\begin{array}{l}{ }^{a} \text { Nonatitai } \\
\text { July } 1 \text {, }\end{array}$ & $\begin{array}{l}\text { nt area de } \\
30 .\end{array}$ & gnation & re as of \\
\hline
\end{tabular}




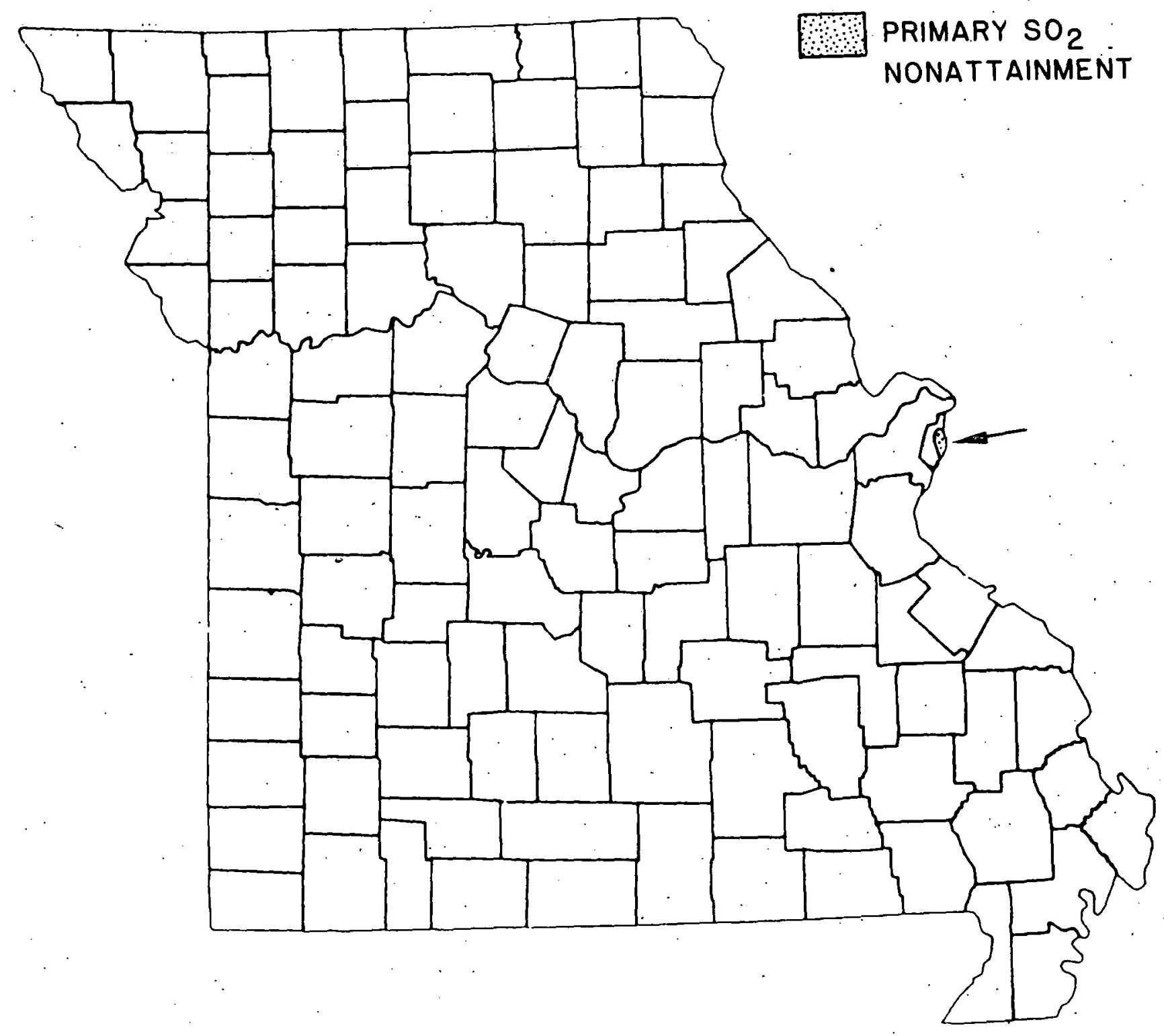

Fig. A.15 Missouri: Areas Designated as Primary $\mathrm{SO}_{2}$ Nonattainment as of July. 1980 


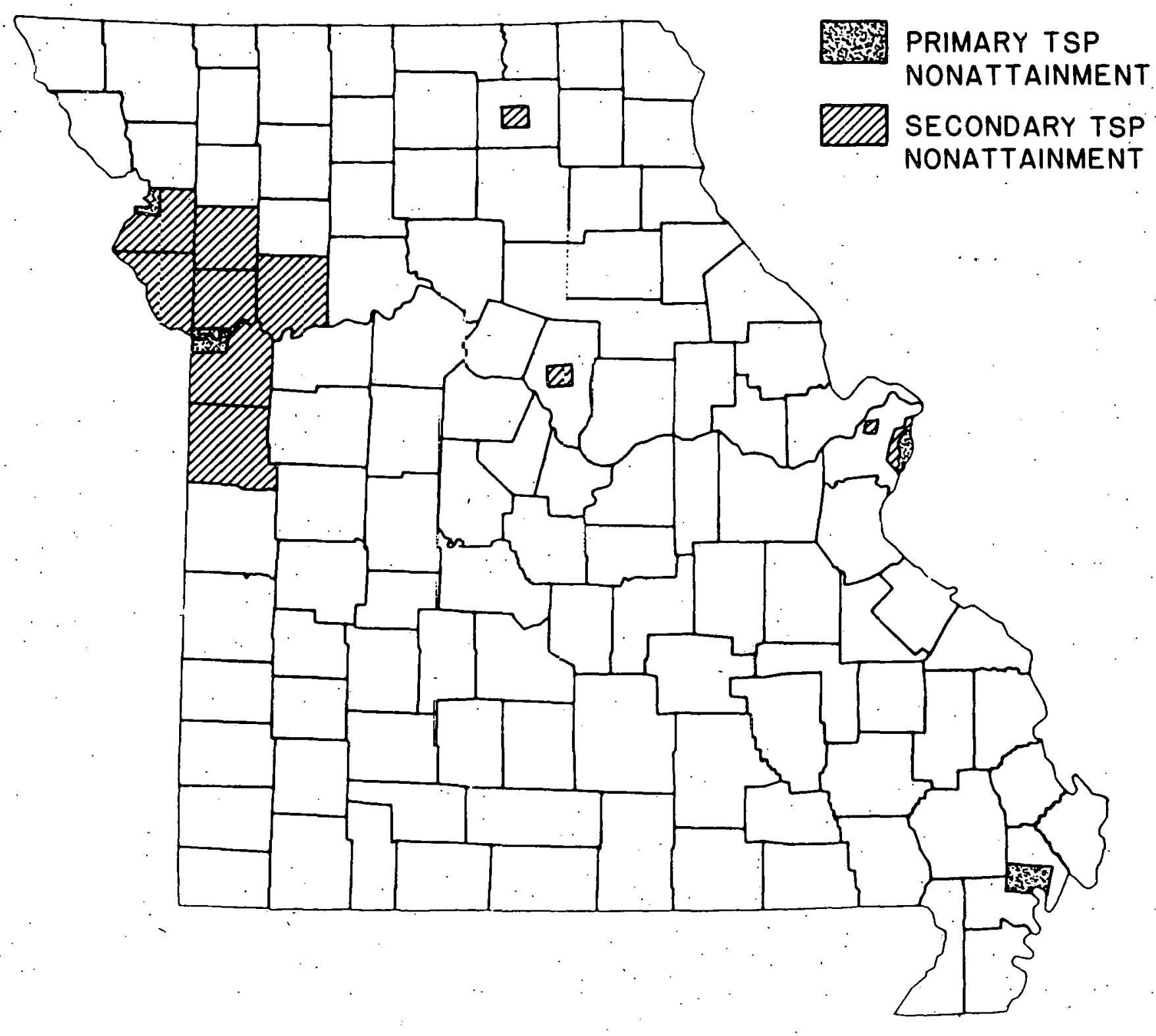

Fig. A.16 : Missouri: Areas Designated as Primary and Secondary TSP Nonattzinment as of July 1980 
Table A.10 New Hampshire: Air Quality Summary

\begin{tabular}{|c|c|c|c|}
\hline \multirow[b]{2}{*}{ Pollutant } & \multirow{2}{*}{$\begin{array}{l}\text { St and ard } \\
\text { Averaging } \\
\text { Period }\end{array}$} & \multicolumn{2}{|c|}{$\begin{array}{c}\text { No. of Discrete } \\
\text { Nonattainment Areas } \\
\end{array}$} \\
\hline & & Primary & Secondary \\
\hline $\mathrm{SO}_{2}$ & $\begin{array}{rl}24 & \mathrm{hr} \\
1 \mathrm{yr}\end{array}$ & 1 & 0 \\
\hline TSP & $\begin{array}{r}24 \mathrm{hr} \\
1 \mathrm{yr}\end{array}$ & 1 & 1 \\
\hline $\mathrm{NO}_{\mathrm{x}}$ & $1 \mathrm{yr}$ & $0^{\mathrm{b}}$ & - \\
\hline $\mathrm{CO}$ & $8 \mathrm{hr}$ & 2 & - \\
\hline $\mathrm{O}_{3}$ & $1 \mathrm{yr}$ & $1 / 3$ state & - \\
\hline
\end{tabular}

aNonattainment area designations are as of July $1,1980$.

$\mathrm{b}_{\text {No }}$ map included. 
PRIMARY TSP NONATTAINMENT

SECONDARY TSP NONATTAINMENT

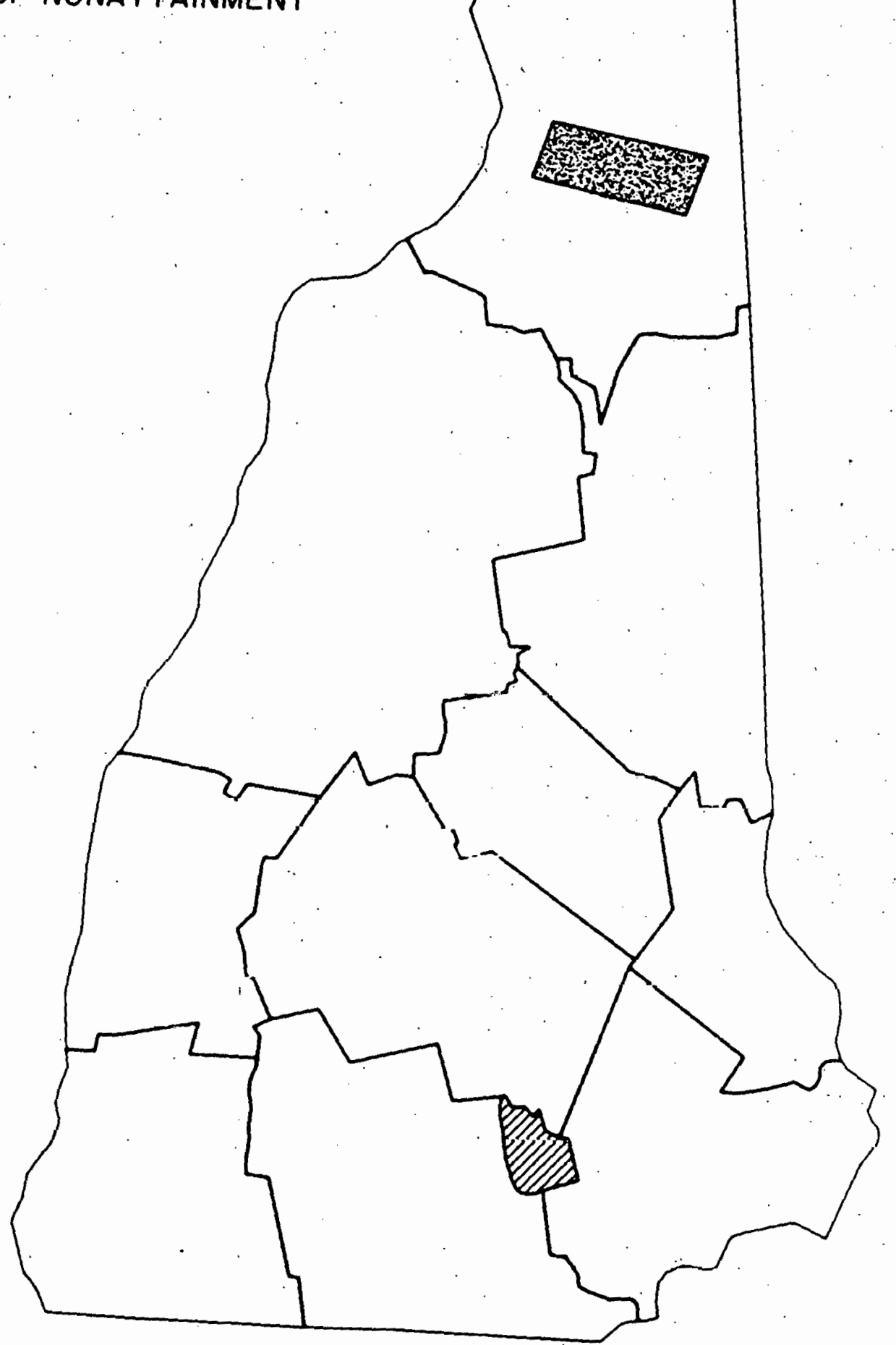

Fig. A.17 New Hampshire: Areas Designated as Primary and Secondary TSP Nonattainment as of July 1980 


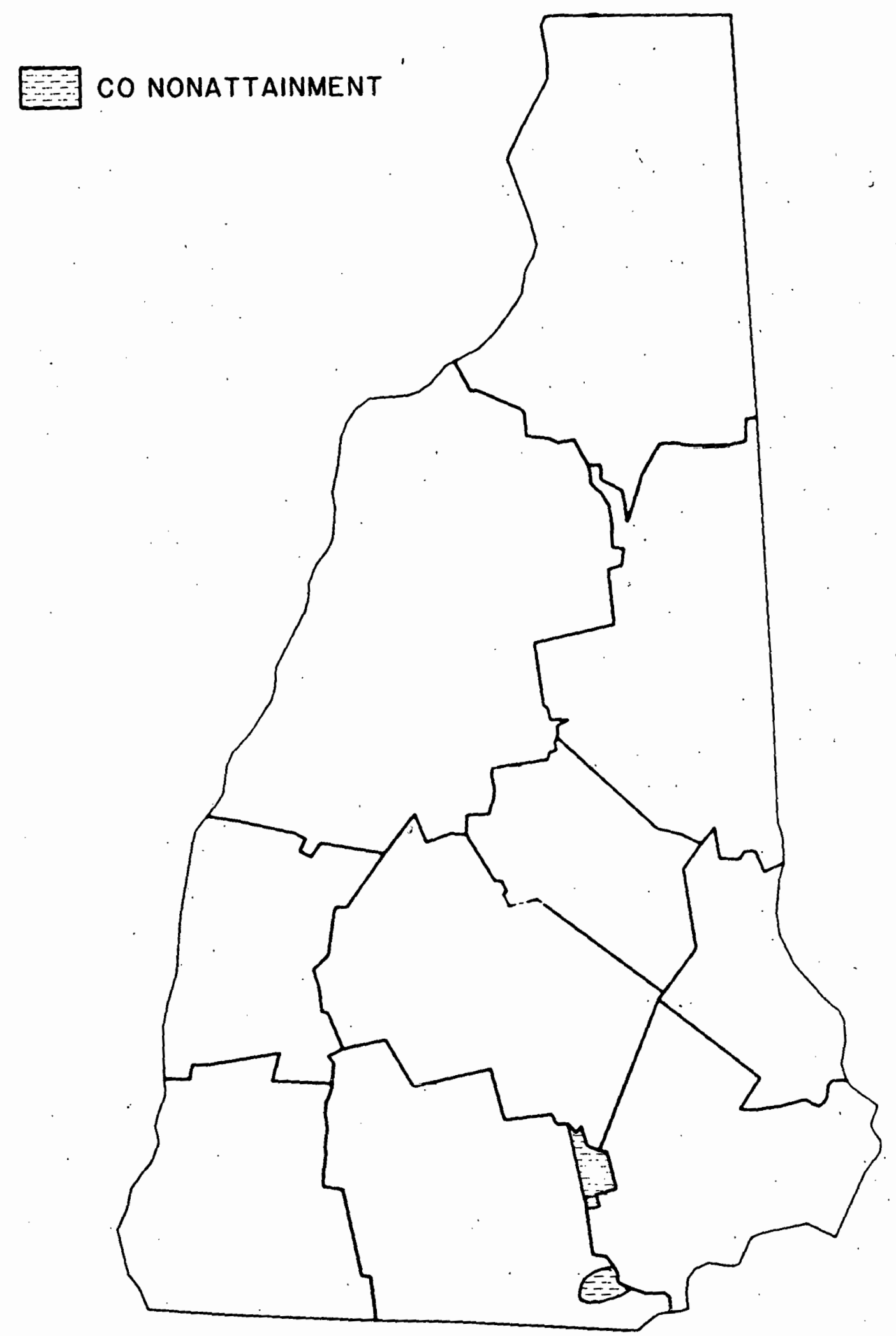

Fig. A.18 New Hampshire: Areas Designated as CO Nonattainment as of July 1980 


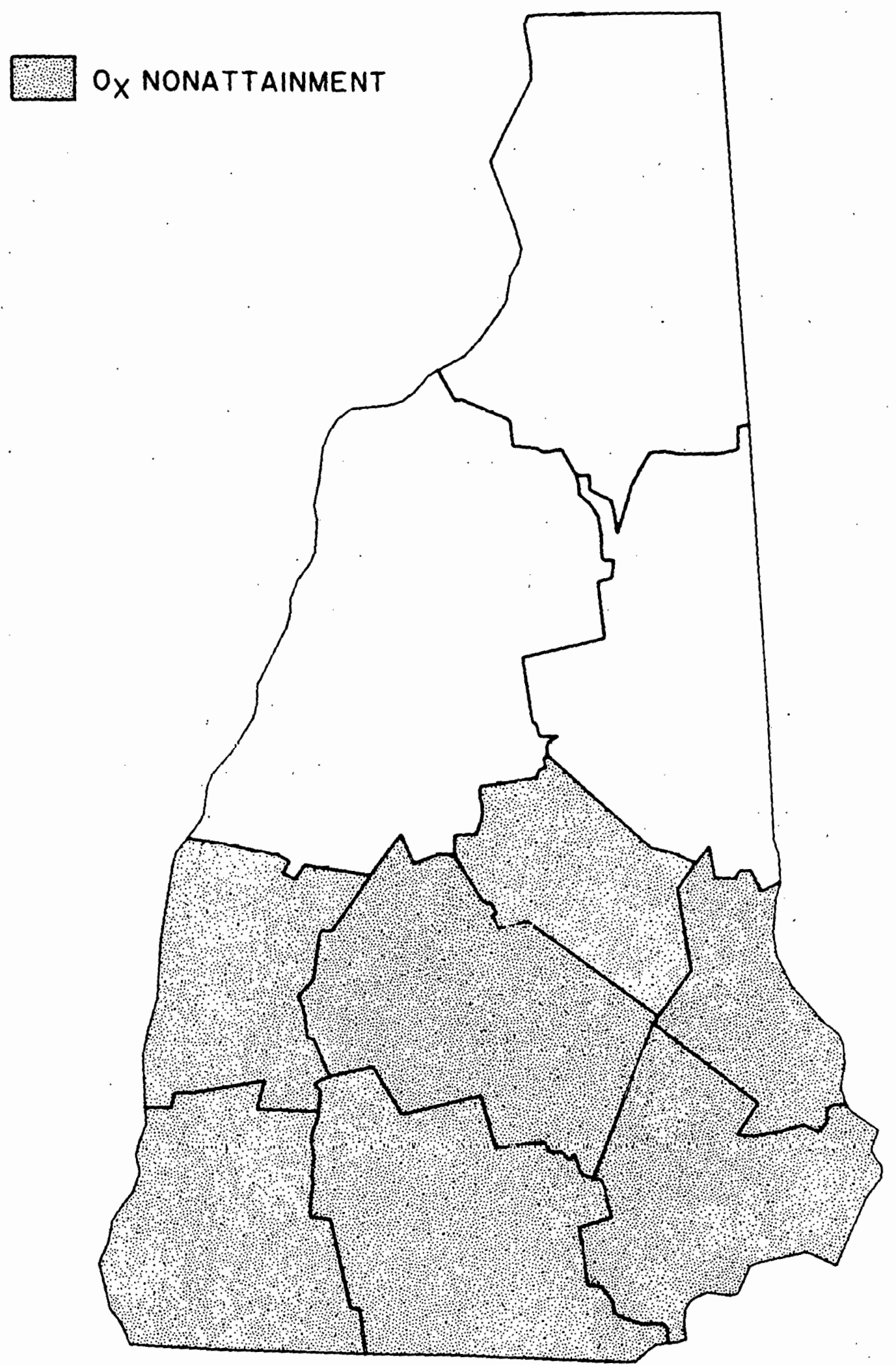

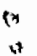

Fig. A.19 New Hampshire: Areas Designated as $\mathrm{O}_{3}$ Nonattainment as of July 1980 
Table A.11 New York: Air Quality Summary

\begin{tabular}{|c|c|c|c|}
\hline \multirow[b]{2}{*}{ Pollut ant } & \multirow{2}{*}{$\begin{array}{l}\text { St andard } \\
\text { Averaging } \\
\text { Period }\end{array}$} & \multicolumn{2}{|c|}{$\begin{array}{l}\text { No. of Discrete } \\
\text { Nonattainment Areas }\end{array}$} \\
\hline & & Primary & Secondary \\
\hline $\mathrm{SO}_{2}$ & $\begin{aligned} 24 \mathrm{hr} \\
1 \mathrm{yr}\end{aligned}$ & 1 & 0 \\
\hline TSP & $\begin{aligned} 24 \mathrm{hr} \\
1 \mathrm{yr}\end{aligned}$ & 3 & 8 \\
\hline $\mathrm{NO}_{\mathbf{x}}$ & $1 \mathrm{yr}$ & $0^{\mathrm{b}}$ & - \\
\hline CO & $8 \mathrm{hr}$ & 9 & - \\
\hline $0_{3}$ & $1 \mathrm{yr}$ & $1 / 3$ state & - \\
\hline
\end{tabular}




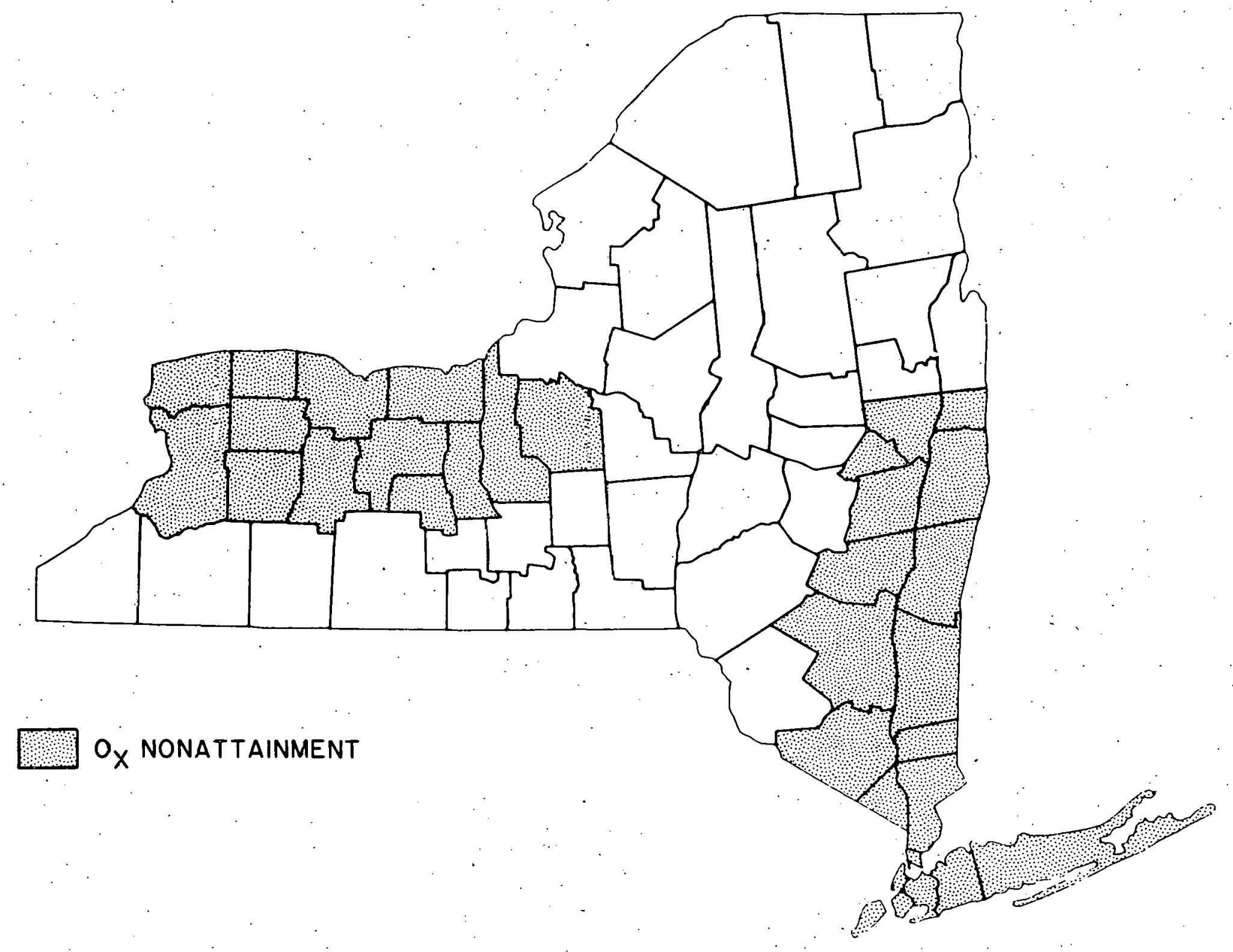

a

Fig. A.20 New York: Areas Designated as $O_{3}$. Nonattainment as of July 1980 
Table. A.12 North Carolina: Air Quality Summary

\begin{tabular}{|c|c|c|c|}
\hline \multirow[b]{2}{*}{ Pollutant } & \multirow{2}{*}{$\begin{array}{l}\text { St and ard } \\
\text { Averaging } \\
\text { Period. }\end{array}$} & \multicolumn{2}{|c|}{$\begin{array}{l}\text { No. of Discrete } \\
\text { Nonat tainment Areas a }\end{array}$} \\
\hline & & Primary & Secondary \\
\hline $\mathrm{SO}_{2}$ & $\begin{array}{rl}24 & \mathrm{hr} \\
1 \mathrm{yr}\end{array}$ & $0^{\mathrm{b}}$ & 0 \\
\hline TSP & $\begin{aligned} 24 \mathrm{hr} \\
1 \mathrm{yr}\end{aligned}$ & $0^{b}$ & 0 \\
\hline $\mathrm{NO}_{\mathbf{x}}$ & 1. yr & $0^{b}$ & - \\
\hline $\mathrm{CO}$ & $8 \mathrm{hr}$ & 1 & - \\
\hline $0_{3}$ & 1. yr & 1 & - \\
\hline
\end{tabular}

${ }^{a}$ Nonat.tainment area designations are as of: July $1,1: 980$.

$\mathrm{b}_{\text {No }}$ map included. 
Table A.13 Ohio: Air Quality Summary

\begin{tabular}{|c|c|c|c|}
\hline \multirow[b]{2}{*}{ Pollutant } & \multirow{2}{*}{$\begin{array}{l}\text { Standard } \\
\text { Averaging } \\
\text { Period }\end{array}$} & \multicolumn{2}{|c|}{$\begin{array}{c}\text { No. of Discrete } \\
\text { Nonattainment Areas a }\end{array}$} \\
\hline & & Primary & Second ary \\
\hline $\mathrm{SO}_{2}$ & $\begin{array}{rl}24 & \mathrm{hr} \\
1 \mathrm{yr}\end{array}$ & 18 & 2 \\
\hline TSP & $\begin{aligned} 24 \mathrm{hr} \\
1 \mathrm{yr}\end{aligned}$ & 26 & 14 \\
\hline $\mathrm{NO}_{\mathrm{x}}$ & $1 \mathrm{yr}$ & $0^{b}$ & - \\
\hline $\mathrm{CO}$ & $8 \mathrm{hr}$ & 7. & - \\
\hline $\mathrm{O}_{3}$ & $1 \mathrm{yr}$ & $2 / 3$ state & - \\
\hline
\end{tabular}




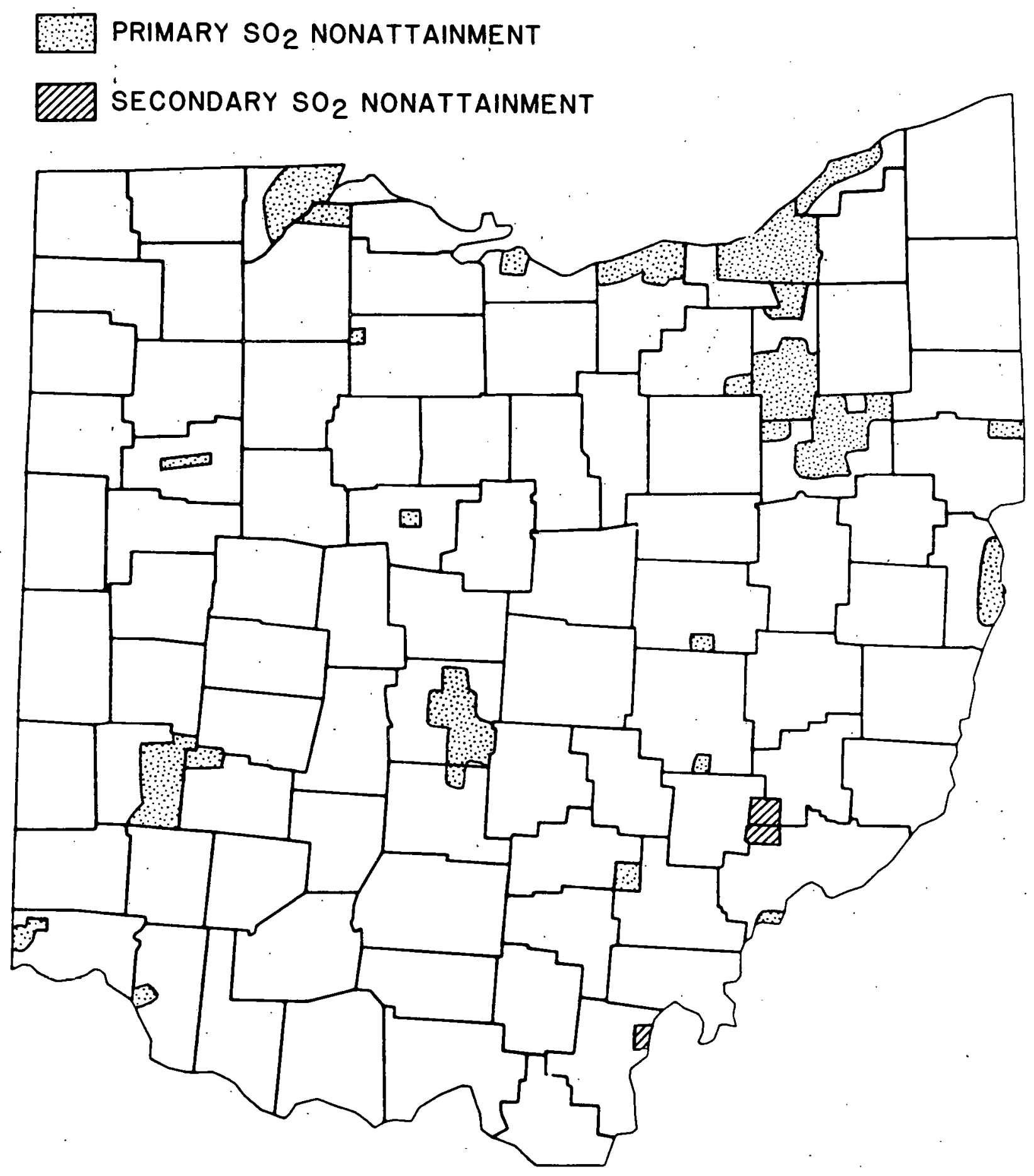

Fig. A.21 Ohio: Areas Designated as Primary and Secondary $\mathrm{SO}_{2}$ Nonattainment as of July 1980 
Table A.14 Pennsylvania: Air Quality Summary

\begin{tabular}{|c|c|c|c|}
\hline \multirow[b]{2}{*}{ Pollutant } & \multirow{2}{*}{$\begin{array}{l}\text { St andard } \\
\text { Averaging } \\
\text { Period }\end{array}$} & \multicolumn{2}{|c|}{$\begin{array}{l}\text { No. of Discrete } \\
\text { Nonattainment Areas a }\end{array}$} \\
\hline & & Primary & Secondary \\
\hline $\mathrm{SO}_{2}$ & $\begin{aligned} 24 \mathrm{hr} \\
1 \mathrm{yr}\end{aligned}$ & 7 & 2 \\
\hline TSP & $\begin{array}{rl}24 & \mathrm{hr} \\
1 \mathrm{yr}\end{array}$ & 6 & 9 \\
\hline $\mathrm{NO}_{\mathrm{x}}$ & $1 \mathrm{yr}$ & $0^{b}$ & - \\
\hline $\mathrm{CO}$ & $8 \mathrm{hr}$ & 2 & - \\
\hline $0_{3}$ & $1 \mathrm{yr}$ & whole stat $\mathrm{e}^{\mathrm{b}}$ & - \\
\hline \multicolumn{4}{|c|}{$\begin{array}{l}\text { a Nonattainment area designations are as of } \\
\text { July } 1,1980 .\end{array}$} \\
\hline
\end{tabular}




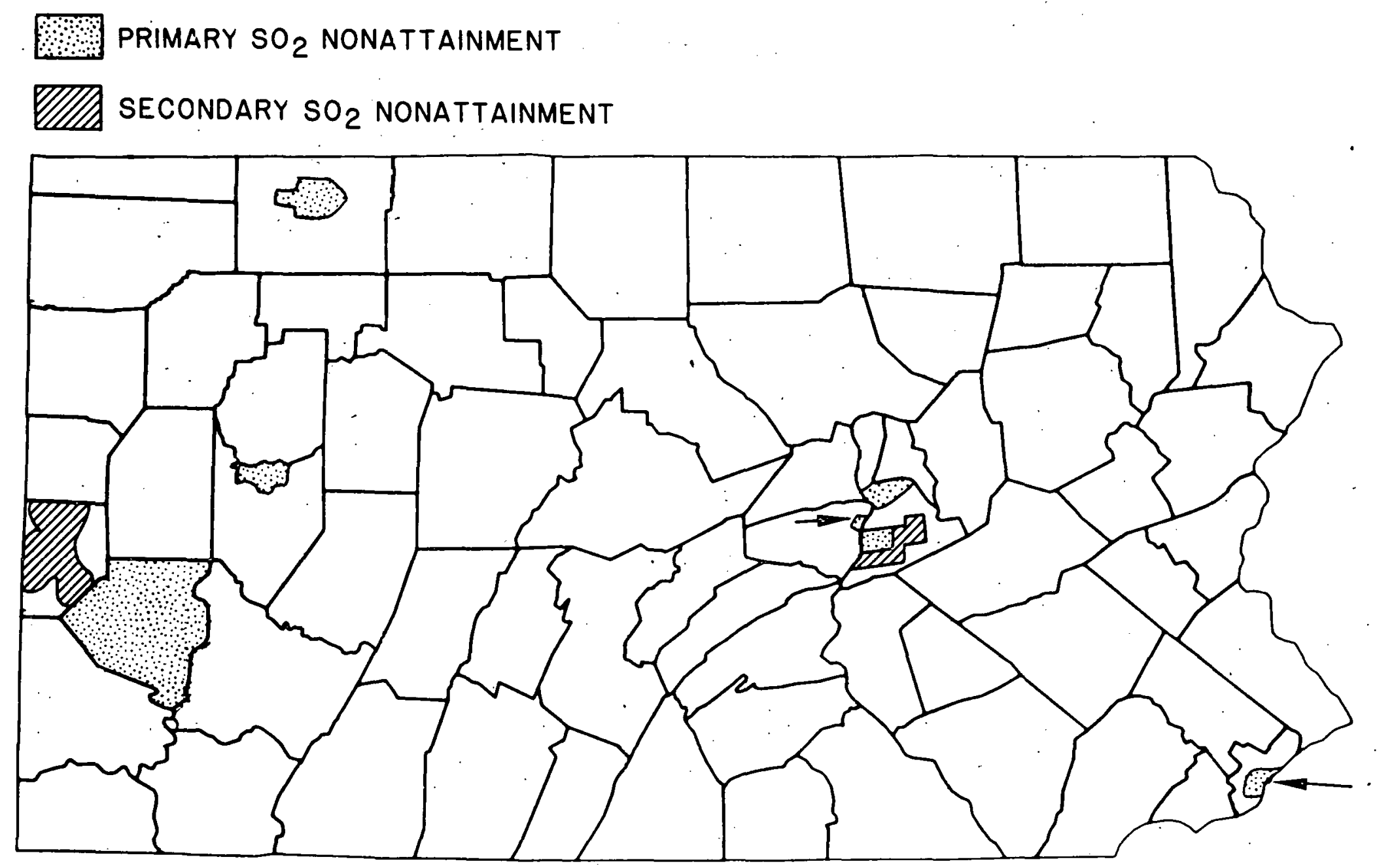

Fig. A.22 Pennsylvania: Areas Designated as. Primary and Secondary $\mathrm{SO}_{2}$ Nonattainment as of July 1980 


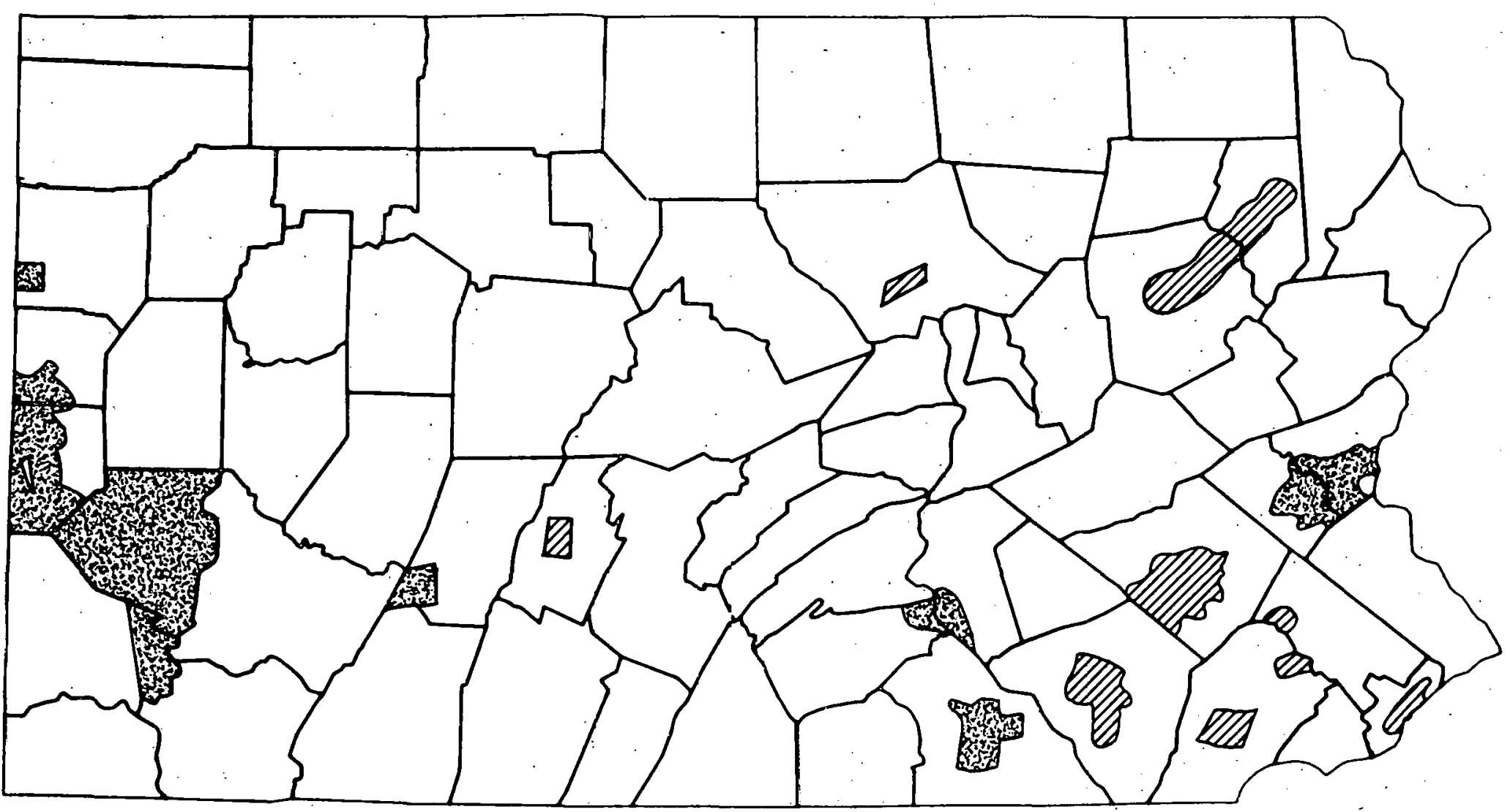

Fig. A.23 Pennsylvania: Areas Designated as Primary and Secondary TSP Nonattainment as of July 1980 
Table A.15 Vermont: Air Quality Summary

\begin{tabular}{|c|c|c|c|}
\hline \multirow[b]{2}{*}{ Pollutant } & \multirow{2}{*}{$\begin{array}{l}\text { Standard } \\
\text { Averaging } \\
\text { Period }\end{array}$} & \multicolumn{2}{|c|}{$\begin{array}{l}\text { No. of Discrete } \\
\text { Nonattainment Areas a }\end{array}$} \\
\hline & & Primary & Second ary \\
\hline $\mathrm{SO}_{2}$ & $\begin{aligned} 24 \mathrm{hr} \\
1 \mathrm{yr}\end{aligned}$ & $0^{b}$ & 0 \\
\hline TSP & $\begin{array}{rl}24 & \mathrm{hr} \\
1 \mathrm{yr}\end{array}$ & 0 & 2 \\
\hline $\mathrm{NO}_{\mathrm{x}}$ & $1 \mathrm{yr}$ & $0^{b}$ & - \\
\hline Co & $8 \mathrm{hr}$ & 1 . & - \\
\hline $0_{3}$ & $1 \mathrm{yr}$ & $3 / 4$ state & - \\
\hline
\end{tabular}


74

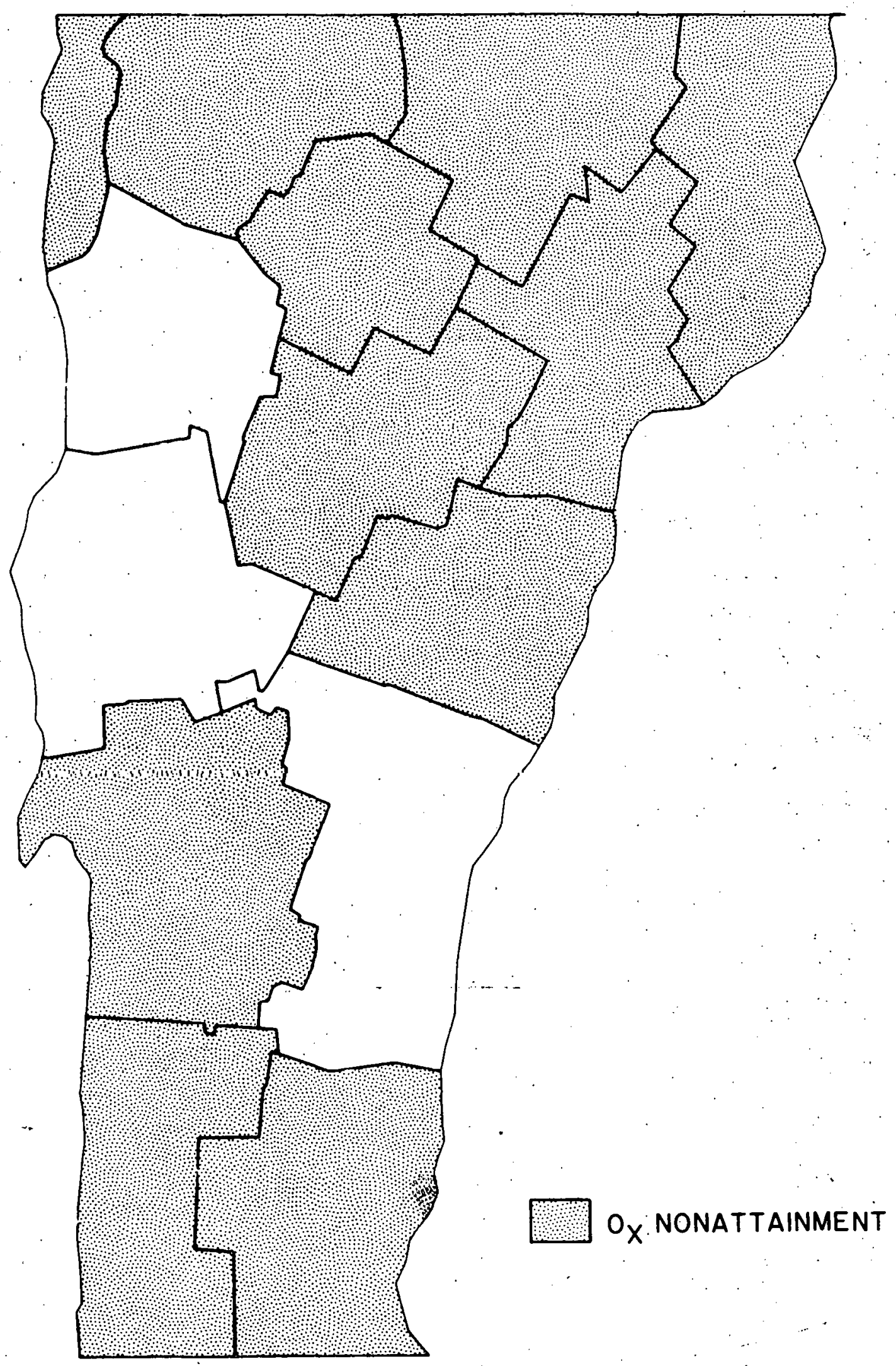

Fig. A.24 Vermont: Areas Designated as $O_{3}$ Nonattainment
as of July 1980 
Table A.16 Washington: Air Quality Summary

\begin{tabular}{|c|c|c|c|}
\hline \multirow[b]{2}{*}{ Pollutant } & \multirow{2}{*}{$\begin{array}{l}\text { Standard } \\
\text { Averaging } \\
\text { Period }\end{array}$} & \multicolumn{2}{|c|}{$\begin{array}{l}\text { No. of Discrete } \\
\text { Nonattainment Areas a }\end{array}$} \\
\hline & & Primary & Secondary \\
\hline $\mathrm{SO}_{2}$ & $\begin{aligned} 24 \mathrm{hr} \\
1 \mathrm{yr}\end{aligned}$ & $0^{b}$ & 0 \\
\hline TSP & $\begin{aligned} 24 \mathrm{hr} \\
1 \mathrm{yr}\end{aligned}$ & 8 & 3 \\
\hline $\mathrm{NO}_{\mathrm{x}}$ & $1 \mathrm{yr}$ & $0^{b}$ & - \\
\hline CO & $8 \mathrm{hr}$ & 3 & - \\
\hline $\mathrm{O}_{3}$ & $1 \mathrm{yr}$ & 2 & - \\
\hline
\end{tabular}


THIS PAGE

\section{WAS INTENTIONALLY \\ LEFT BLANK}


APPENDIX B

COAL PRODUCTION, QUALITY, AND RESERVES 
THIS PAGE

WAS INTENTIONALLY

LEFT BLANK 


\section{APPENDIX B}

COAL PRODUCTION, QUALITY, AND RESERVES

In this section, we present coal quality and production data for the coal-producing counties. Fuel-burning facilities may find these data helpful when forming policies to meet air pollution regulations.

The coal quality data for each state are presented in tables that include sulfur content (expressed as $1 \mathrm{~b} \mathrm{sO}_{2} / 10^{6} \mathrm{Btu}$ ), ash content, and heating value $(B t u / 1 b)$ averaged for each coal-producing county. Also included are coal washability data presented as average sulfur removal (\%) and average Btu loss $(\%)$.

- State maps of average sulfur content of coal by. county are also given. These data are presented in the following five ranges, with approximate equivalent percentages:

\begin{tabular}{cc}
$1 \mathrm{~b} \mathrm{SO}_{2} / 10^{6} \mathrm{Btu}$ & $\frac{\% \mathrm{~s}}{0-0.75}$ \\
\hline $0-1.2$ & $0.75-2.0$ \\
$1.2-3.2$ & $2.0-3.5$ \\
$3.2-5.6$ & $3.5-5.0$ \\
$5.6-8.0$ & $>5.0$ \\
$>8.0$ &
\end{tabular}

Coal quality data are based on steam coal deliveries in 1979 as reported to DOE on Energy Information Agency (EIA) Form 423. Washability data came from characterizations of coal samples presented in Bureau of Mines Report RI 8118 .

Coal production in 1979 is mapped by county for each state. In addition, a table lists, by county, production levels in 1979, projected produc$t$ ion levels in 1985, and estimated reserves. The 1979 production levels are based on steam coal deliveries reported on the EIA form. The 1985 production levels were projected from individual mine-expansion plans reported by the National Coal Assn. and DOE's Western Coal Development Monitoring System. Estimated coal reserves were derived from Bureau of Mines Reports IC 8680 and IC 8693 .

Coal quality data are available only for counties with current production. Some coal production data could not be assigned to specific counties. These data are classified as "various" and the state totals are adjusted to include them. Maps for Michigan, Oregon, and South Dakota were not available, but coal reserve data for these states are 1 isted at the end of this appendix. 
Table B.l Alabama: Coal Quality Data

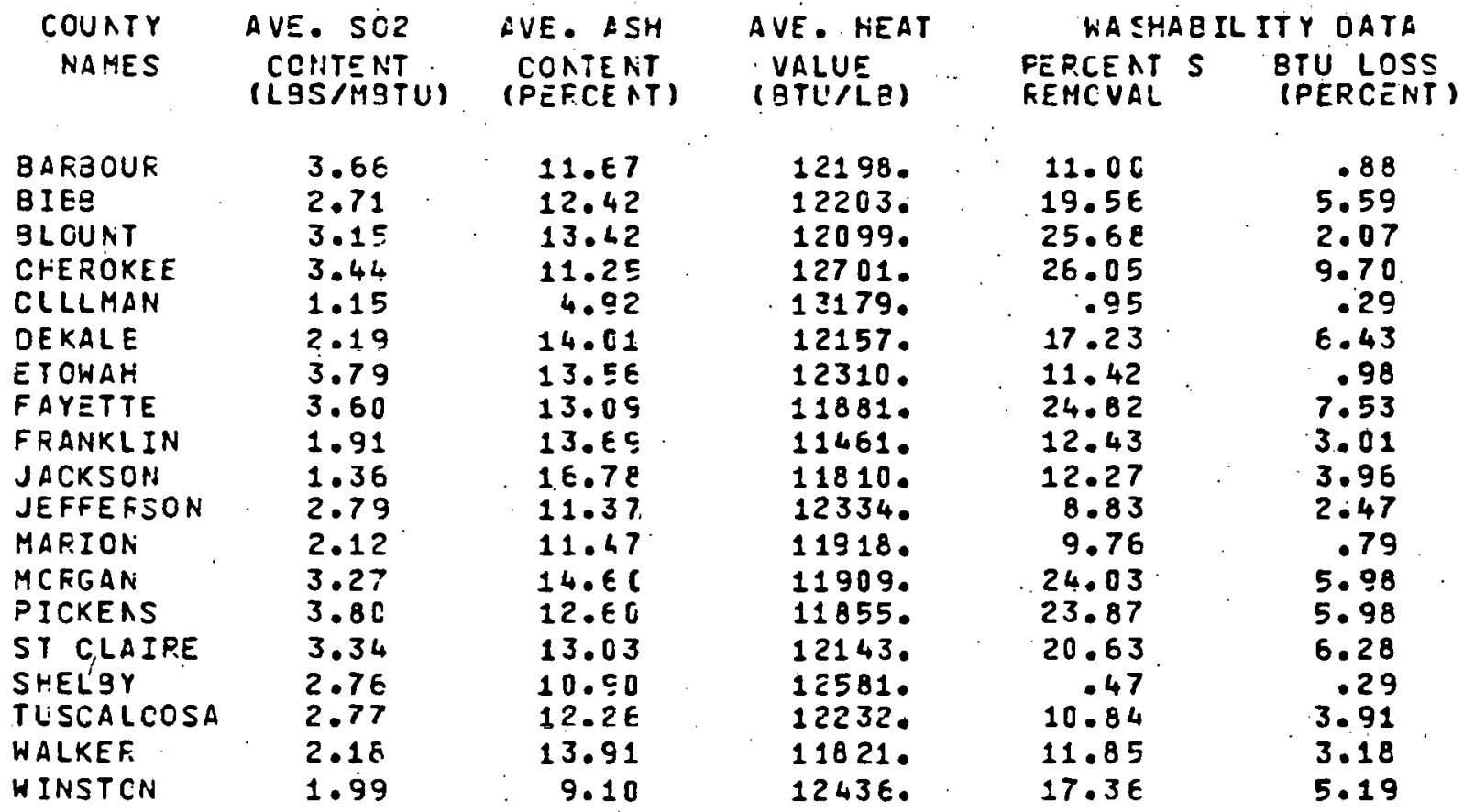




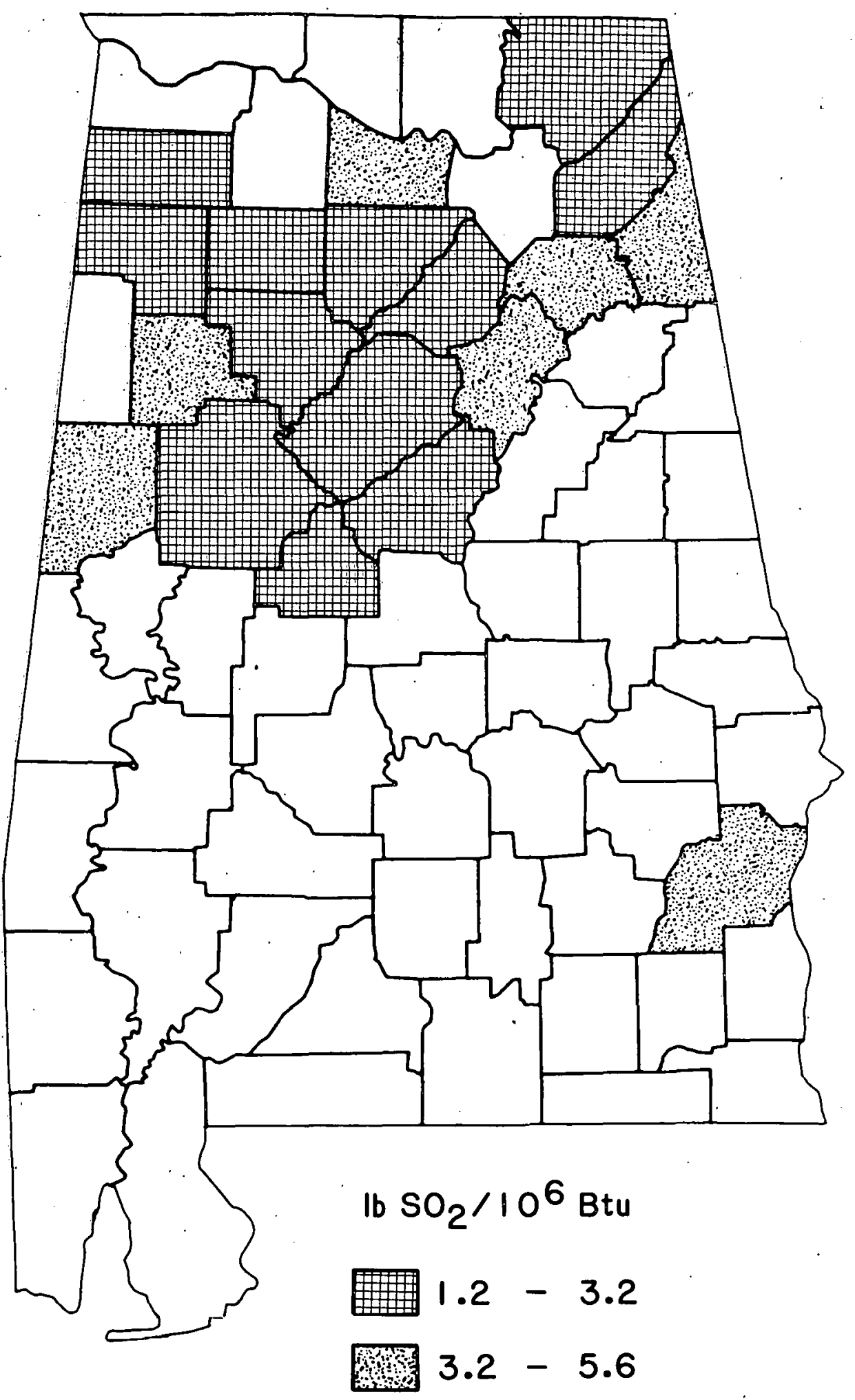

Fig. B.1 Alabama: Average Sulfur Content of Coal 
Table B.2 Alabama: Coal Production and Reserves Tonnage

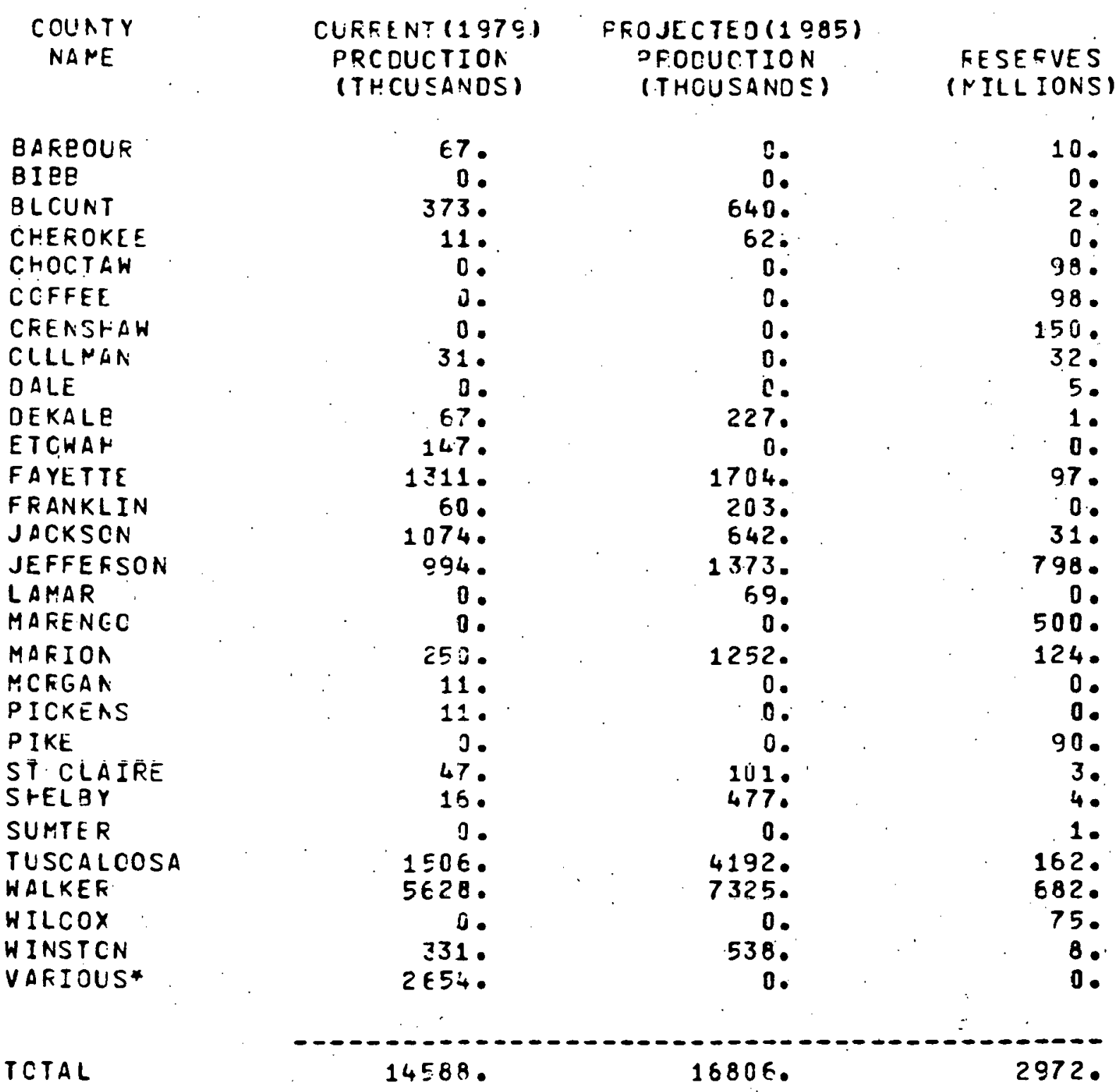

* this figure fepresents cata not assignec to a sfecific county. 


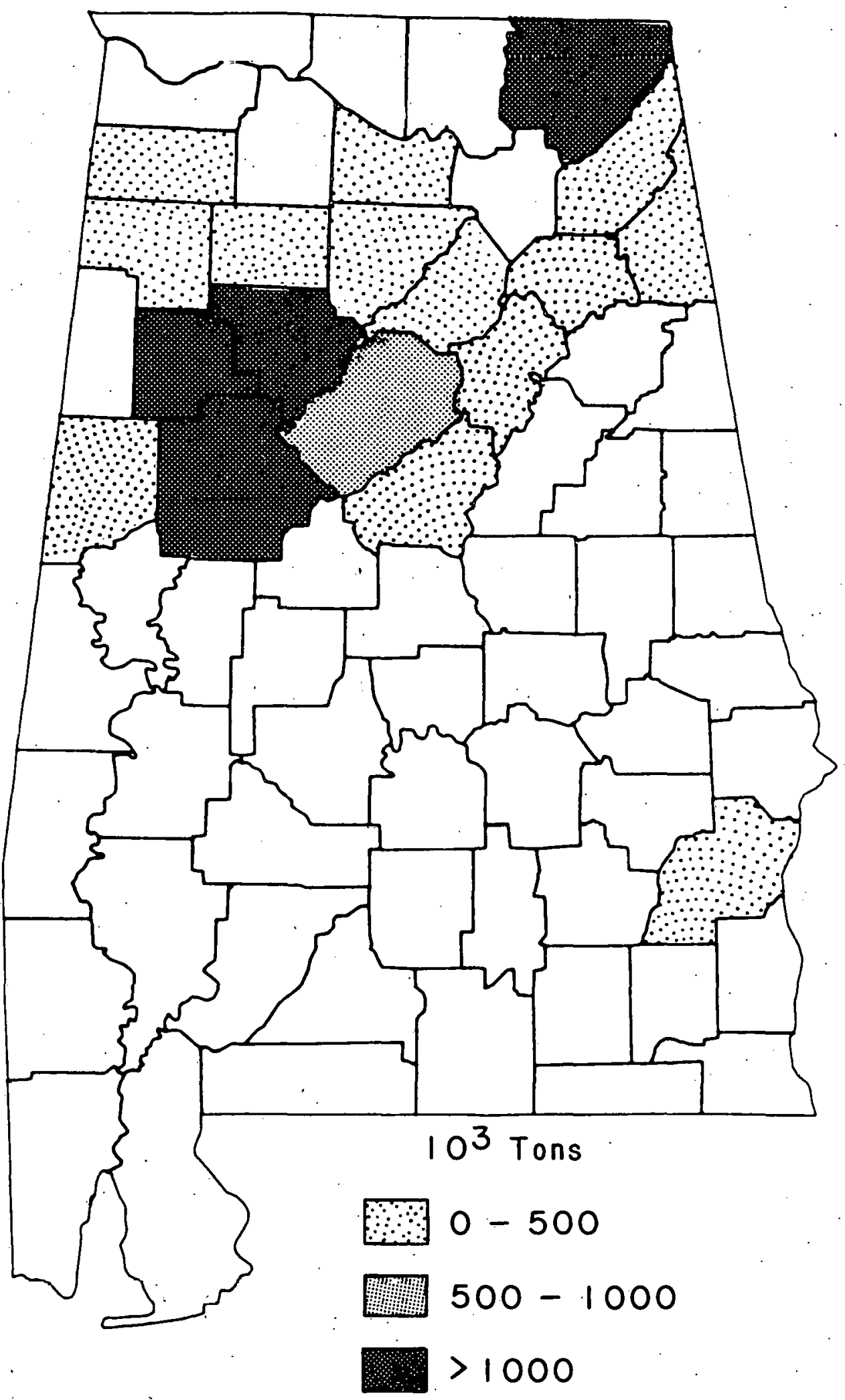

Fig. B.2 Alabama: Coal Production in 1979 
Table B.3 Arizona: Coal Quality Data

$$
\begin{aligned}
& \text { COUNTY } \\
& \text { NAMES }
\end{aligned}
$$

NAVAJG

\begin{abstract}
AVE. SO2
CONTENT (LBS/METU)
\end{abstract}

.90
AVE. ASH CONTENT (PERCEAT)

0.96
AVE, HEAT VALUE ( $S T U / L B$ )

10839.
RASHABIL ITY JATA FERCEAT S BTU LOSS REMCVAL

(PERCENT)

$$
4.83
$$

2.45 


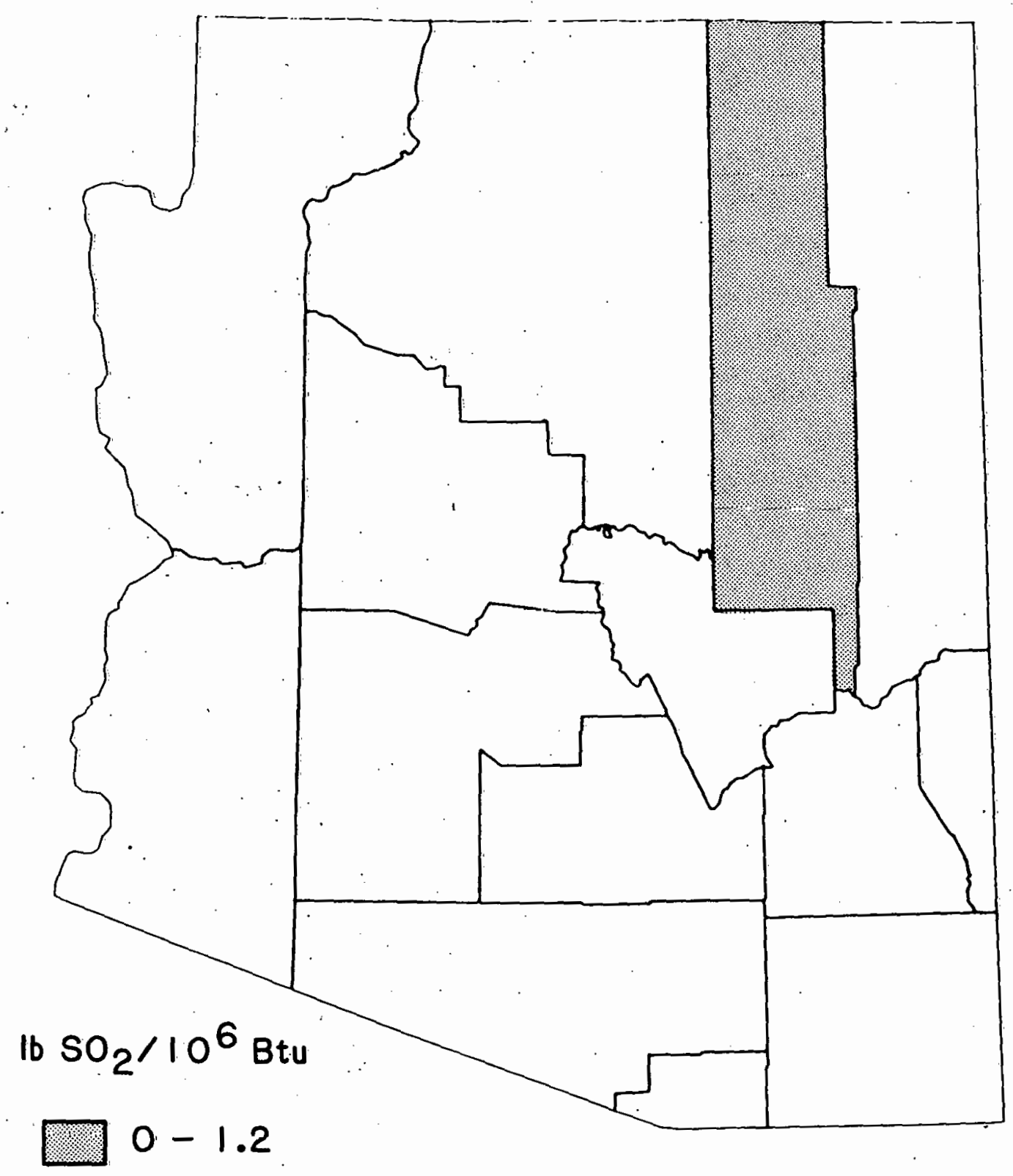

Fig. B.3 Arizona: Average Sulfur Content of Coal 
Table B.4 Arizona: Coal Production and Reserves Tonnage

COUNTY

NAME
CURP ENT (1979)

PRODUCTION

(THCUSANOS)

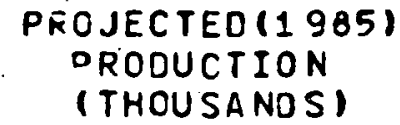

DRODUCTION

(THOUSANOS)
RESERVES

(PILLIONS)
APACHE
CCCCNINO
NAVAJO
VARIOUS*

TOTAL

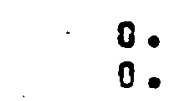

10109 .

381 .
0 .

0 .

14866 .

0.
.21. 35. 2.94.

* this figuRE represents data not asSigned to a sfECific county. 


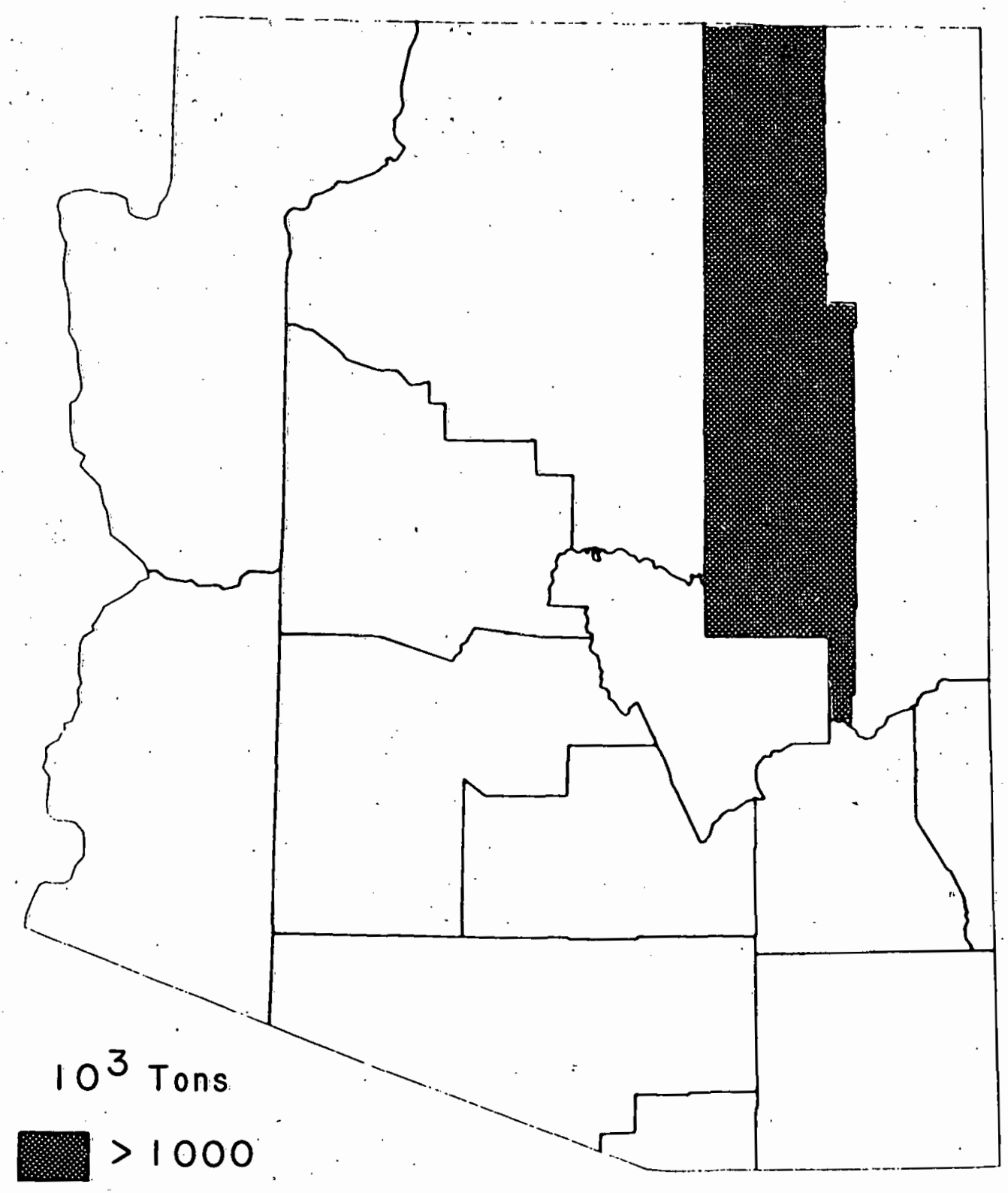

Fig. B.4 Arizona: Coal Production in 1979 
Table B.5 Arkansas: Coal Quality Data

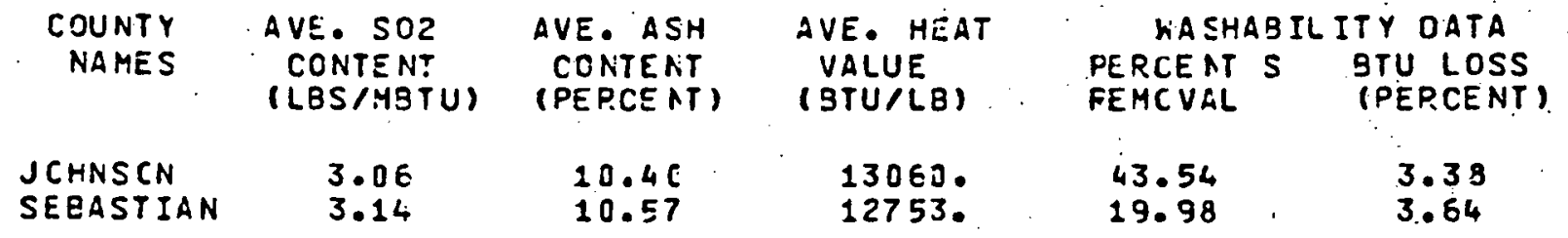




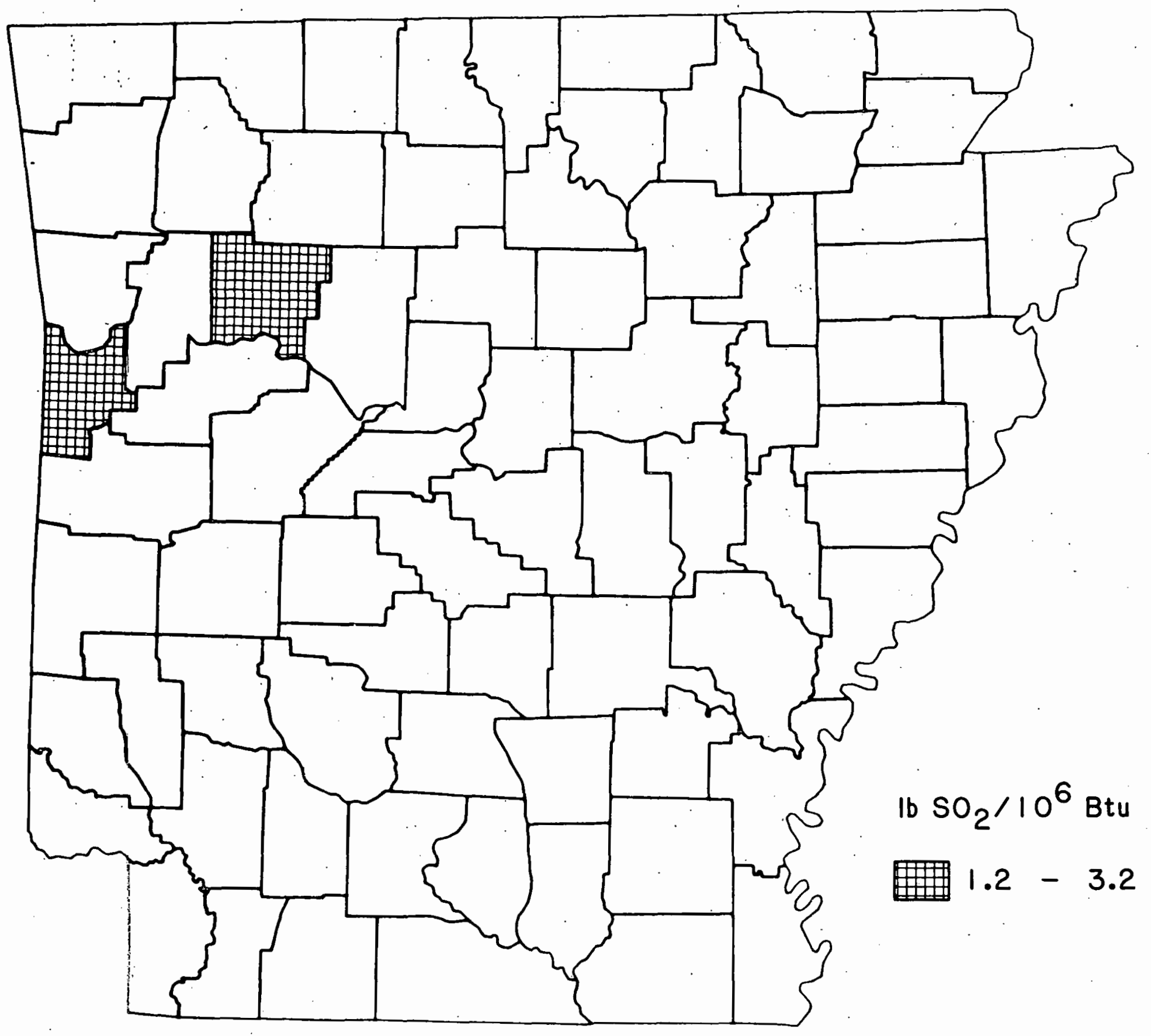

Fig. B.5. Arkansas: -Average Sulfur Content of Coal - 
Table B.6 Arkansas: Coal Production and Reserves Tonnage

\section{COUNTY \\ NAPE}

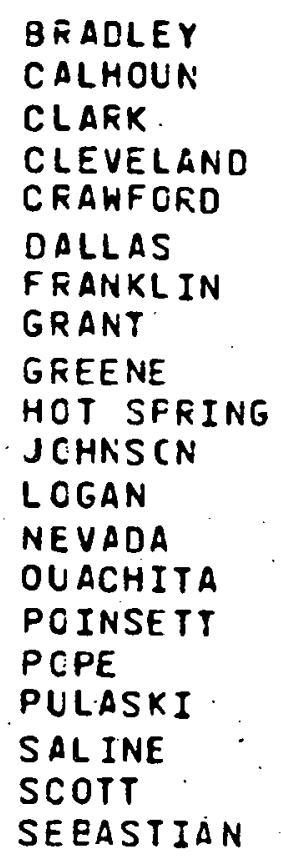

TCTAL

\section{CURRENT(1979) PROJECTED(1985). \\ PRODUCTICA \\ (THOUSANOS) \\ (THOUSANOS)}

FE SERVES

(MILLIONS)

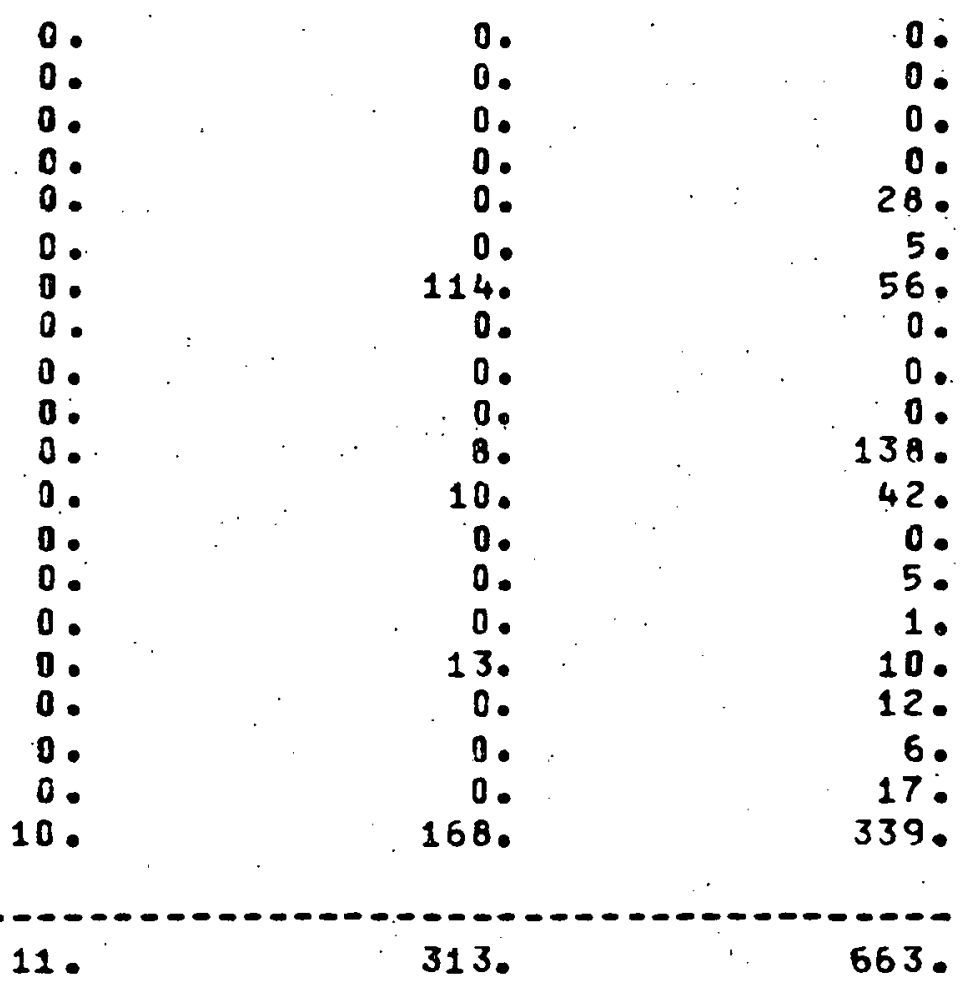




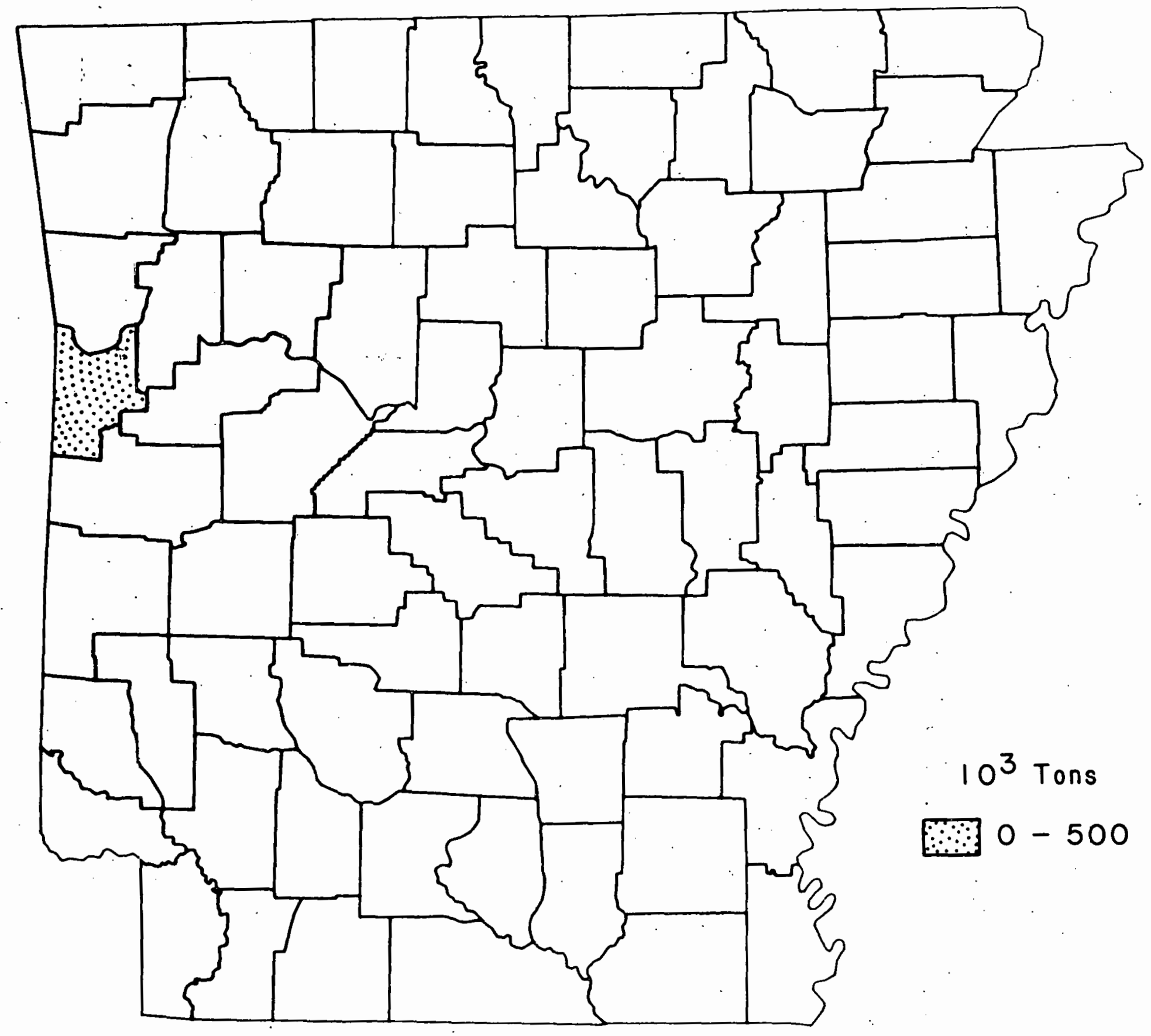

Fig. B.6 Arkansas: Coal Production in 1979 
Table B.7 Colorado: Coal Quality Data

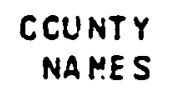

DELTA

EAGLE

FREMONT

GARF IE LD

GUNNISCN

JACKSOA

LAS ANIMAS

MESA.

MCFFAT

MCNTE ZUMA

RCUTT

$$
\begin{aligned}
& \text { AVE. SOL } \\
& \text { CONTENT } \\
& \text { (LBS/METU) }
\end{aligned}
$$

AVE. HEAT
VALUE
(BTU/LE)

11195.

10188 .

9699 .

11302 .

12233 .

1074.4 .

10214.

11479.

10272 .

11418 .

10952 .
HASHABIL ITY DATA

PERCENT S BTU LOSS
REMCVAL

$$
\begin{array}{r}
4.67 \\
6.55 \\
7.59 \\
6.92 \\
.75 \\
6.88 \\
10.60 \\
.36 \\
1.85 \\
11.35 \\
3.83
\end{array}
$$


: $\mathrm{lbO}_{2} / 10^{6} \mathrm{Btu} \square 0-1.2$ 1.2-3.2

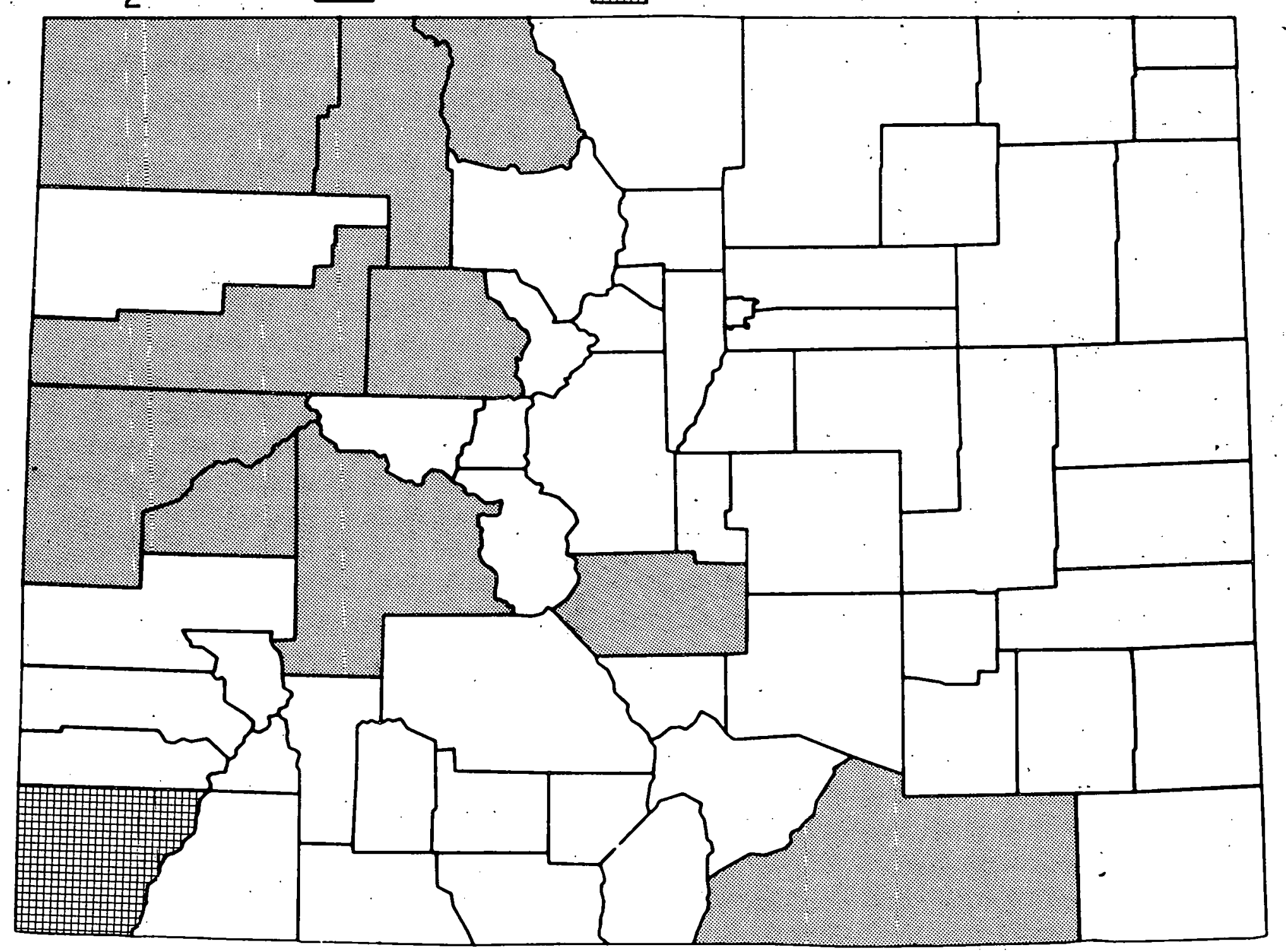

Fig. B.7 Colorado: Average Sulfur Content of Coal 
Table B.8 Colorado: Coal Production and Reserves Tonnage

\section{COUNTY \\ NAME}

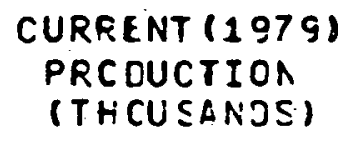

ACAMS

ARAPAROE

AFCHULETA

BCULOER

OELTA

DCUGLAS

EAGLE

ELBERT

EL PASO

FRERCAT

GARF IELD

GUNNISON

HUERFANO

JACKSON

JEFFEFSON

LA PLATA

LAS ANIMAS

MESA

MCFFAT

MCNTE ZUMA

MCNT FCSE

OURAY

PARK

PITKIN

RIO BLANCO

ROUTT

HELC

VARIOUS*

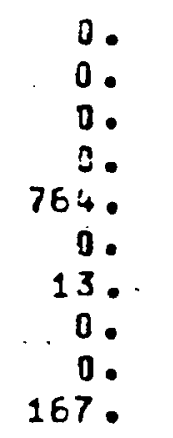

4.

556.

0 .

539.

0 .

0 .

36.

7.

1892 .

120 .

0 .

0 .

0 .

0 .

3.

6? 45.

0 .

820 .

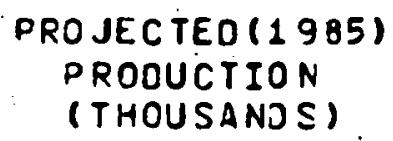

(THOUSANDS)

RESERVES

(HILL IONS)

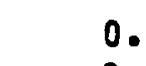

0.

0 .

0 .

2264.

0.

D.

0 .

0.

91.

3501.

3172 .

0 .

3220.

0.

17.

1200 .

2457.

10357 .

0 .

38.

0 .

0 .

2090.

0.

7047.

67.
123.

70 .

92.

163.

270 .

5.

0 .

249.

124.

178.

551.

943.

276.

949.

176.

321.

828.

237 .

2841.

19.

203.

763.

25.

88.

1061.

3824.

461.

0 .

TGTAL

* this figure pepresents data not assigned tC a specific county. 


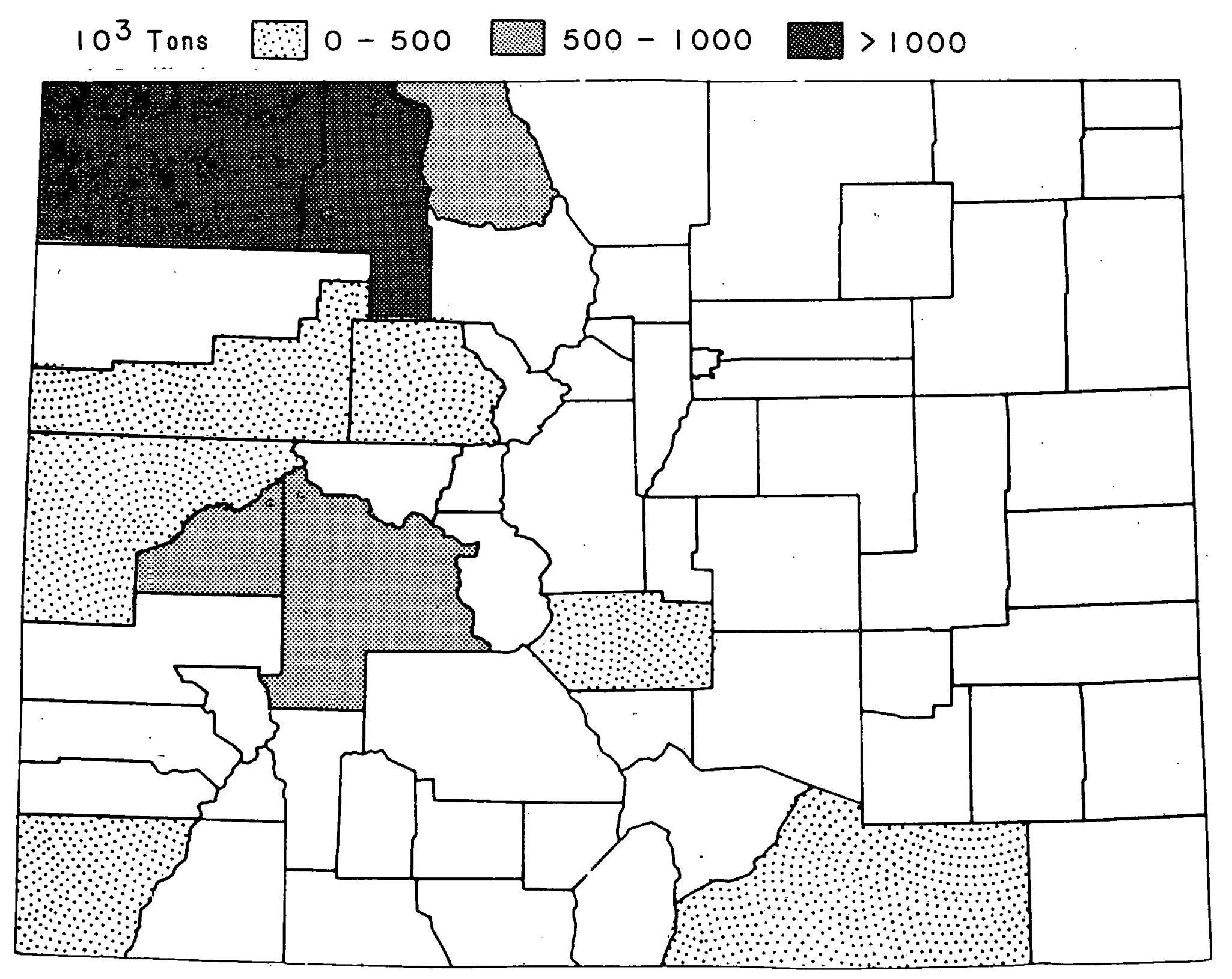

Fig. B.8 Colorado: Coal Production in 1979 
Table B.9 Georgia: Coal Quality Data

$\begin{array}{lccc}\begin{array}{c}\text { COUNTY } \\ \text { NAMES }\end{array} & \begin{array}{c}\text { AVE. SO2 } \\ \text { CONTENT } \\ \text { (LES/METU) }\end{array} & \begin{array}{c}\text { AVE.ASH } \\ \text { CCATENT } \\ \text { (PERCENT) }\end{array} & \begin{array}{c}\text { AVE. HEAT } \\ \text { VALUE } \\ \text { (BTU/LB) }\end{array} \\ \text { OADE } & 1.27 & 5.64 & 13790 . \\ \text { HALKEF } & 5.28 & 14.10 & 12000 .\end{array}$

HASHABILITY DATA
PERCEAT S BTU LOSS
FEMCVAL
(PERCENT)
.00
.00




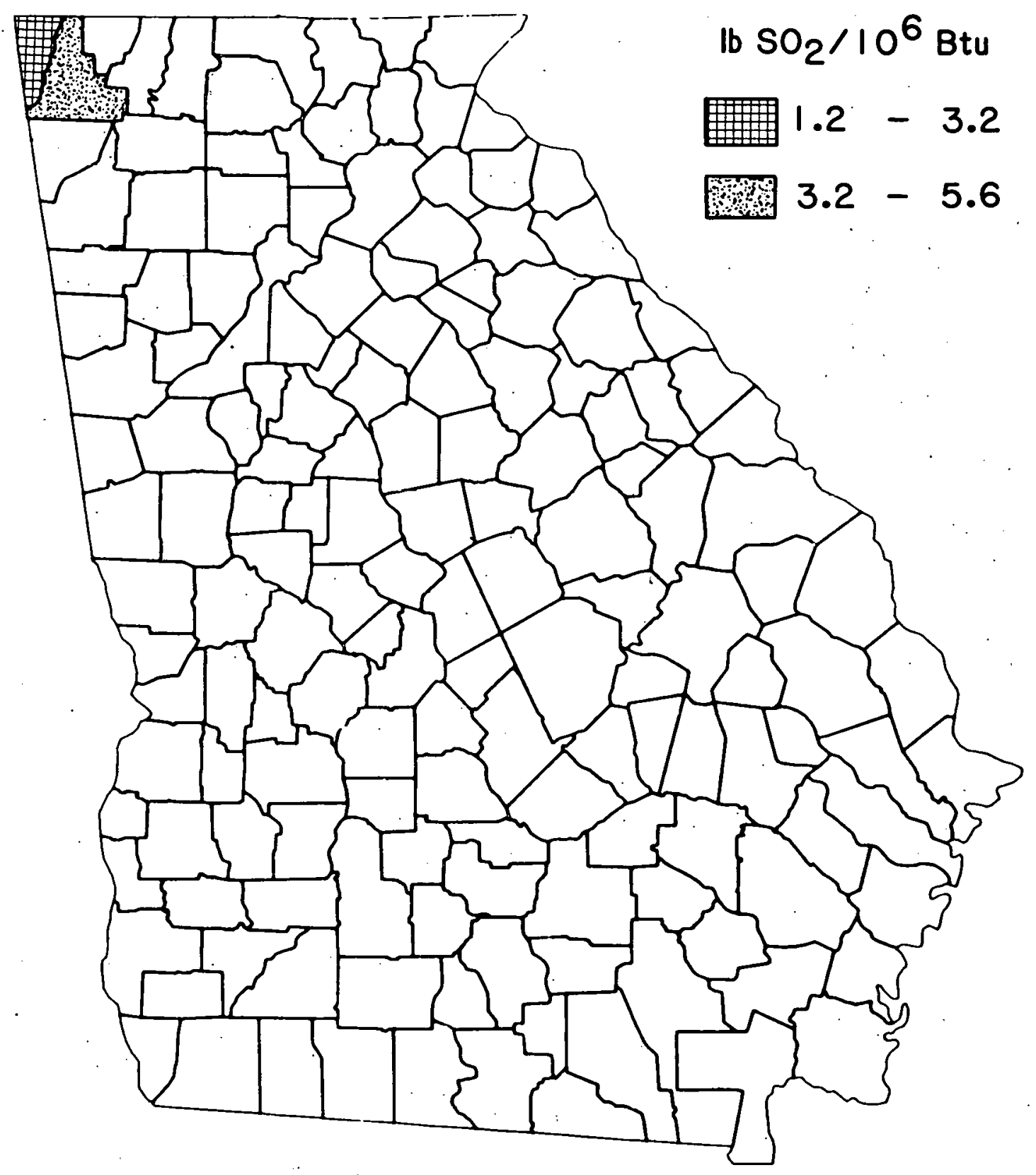

Fig. B.9 Georgia: Average Sulfur Content of Coal 
Table B.10 Georgia: Coal Production and Reserves Tonnage

COUNTY

NA ME

CHATTCOGA

DADE

WALKER

TCTAL CURRENT (1979)

PRODUCTICN

(THCUSANOS)
PRO JECTED (1985)

DPODUCTION

(THOUSANOS)
RESEPVES

(MILLIONS)

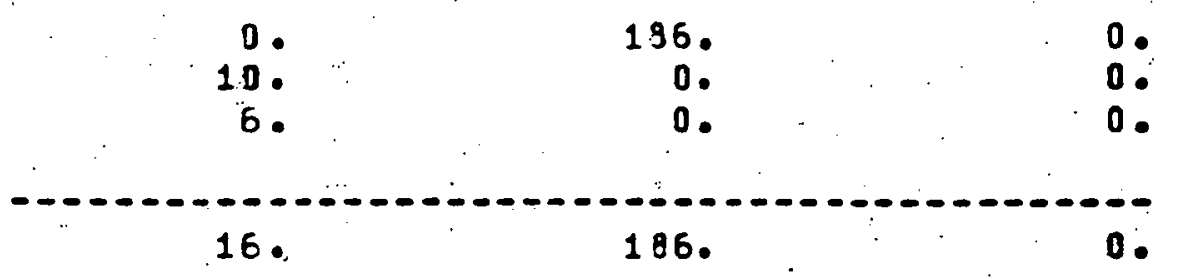




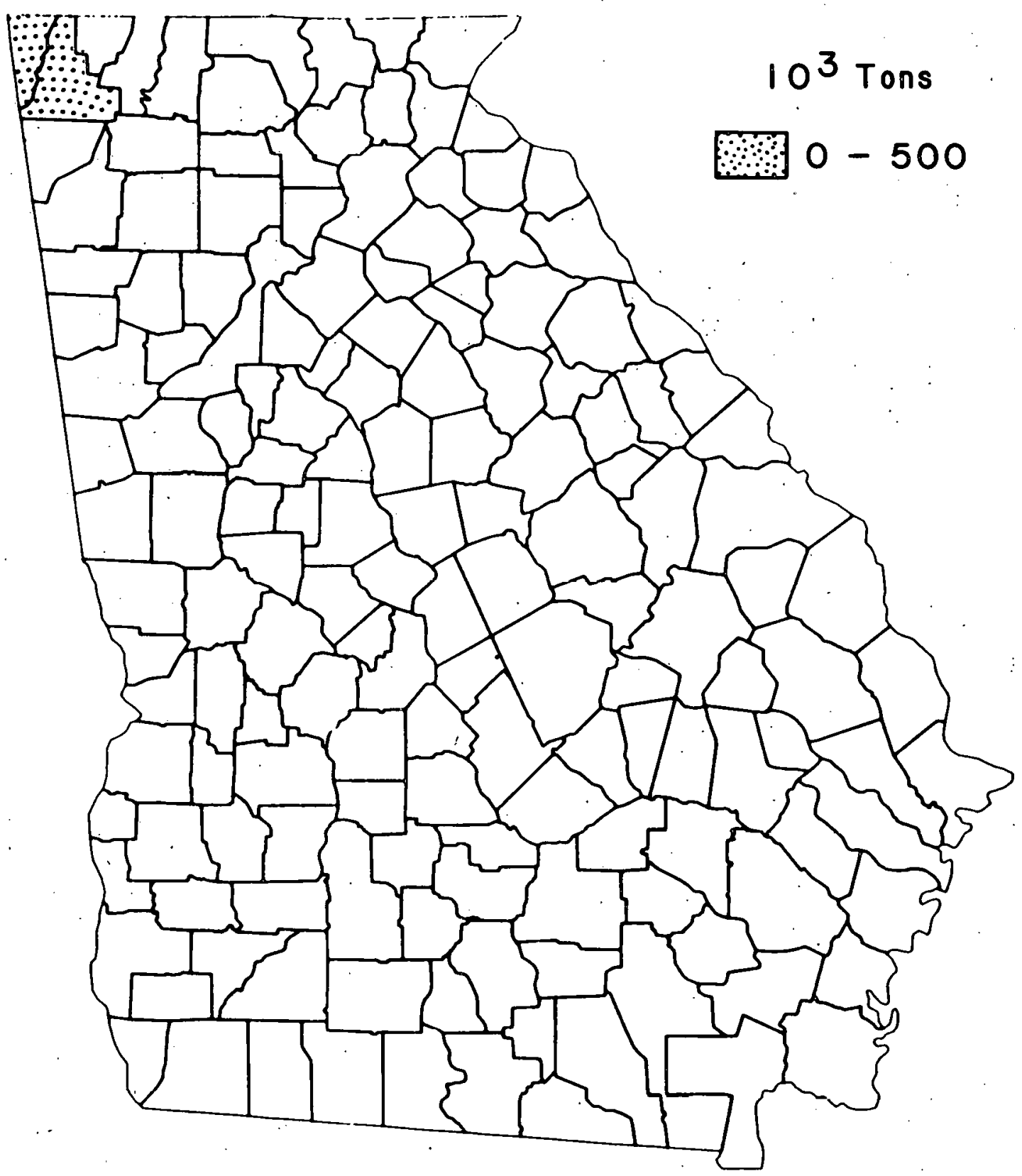

Fig. B.10 Georgia: Coal Production in 1979 
Table B.11 Illinois: Coal Quality Data

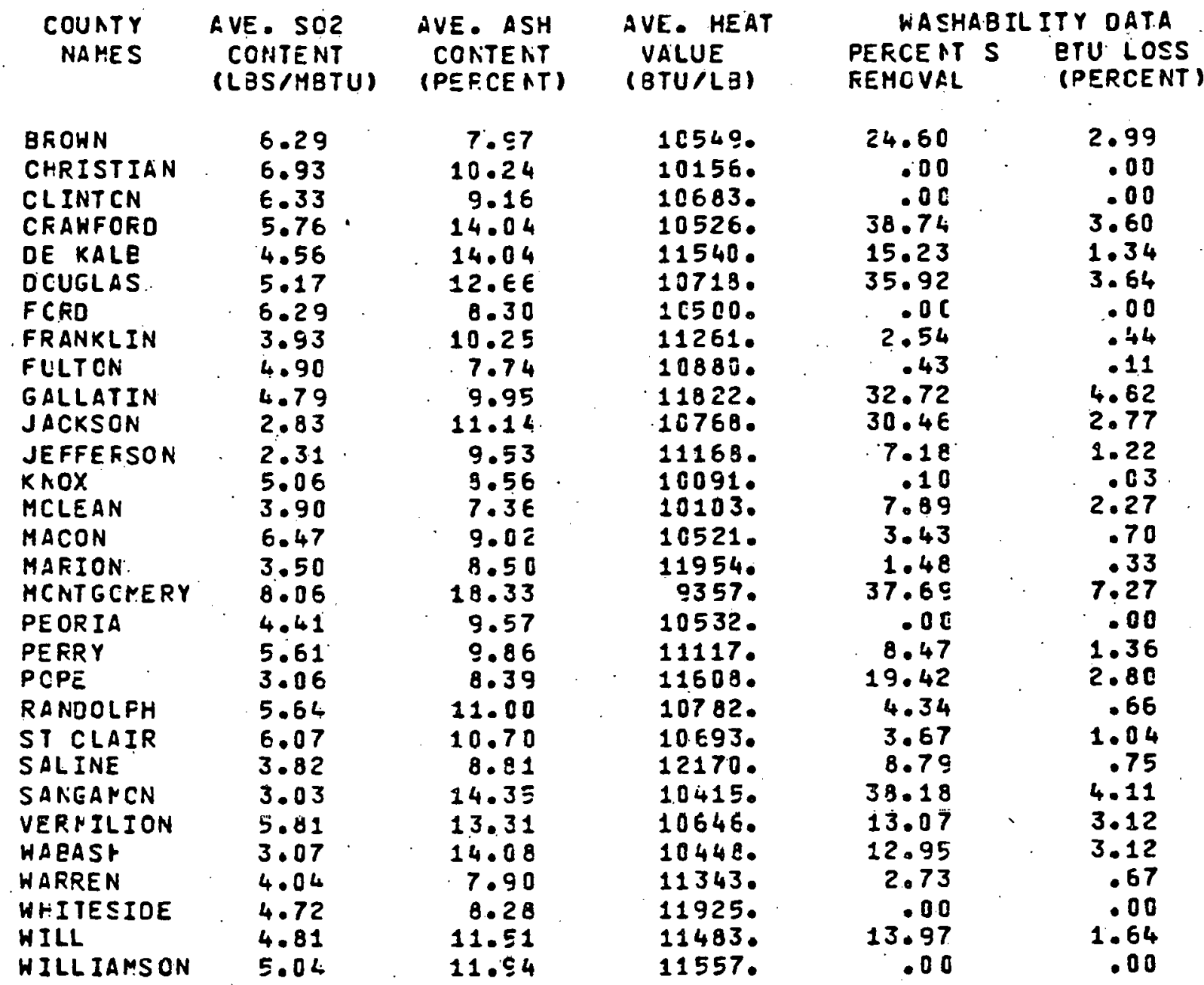




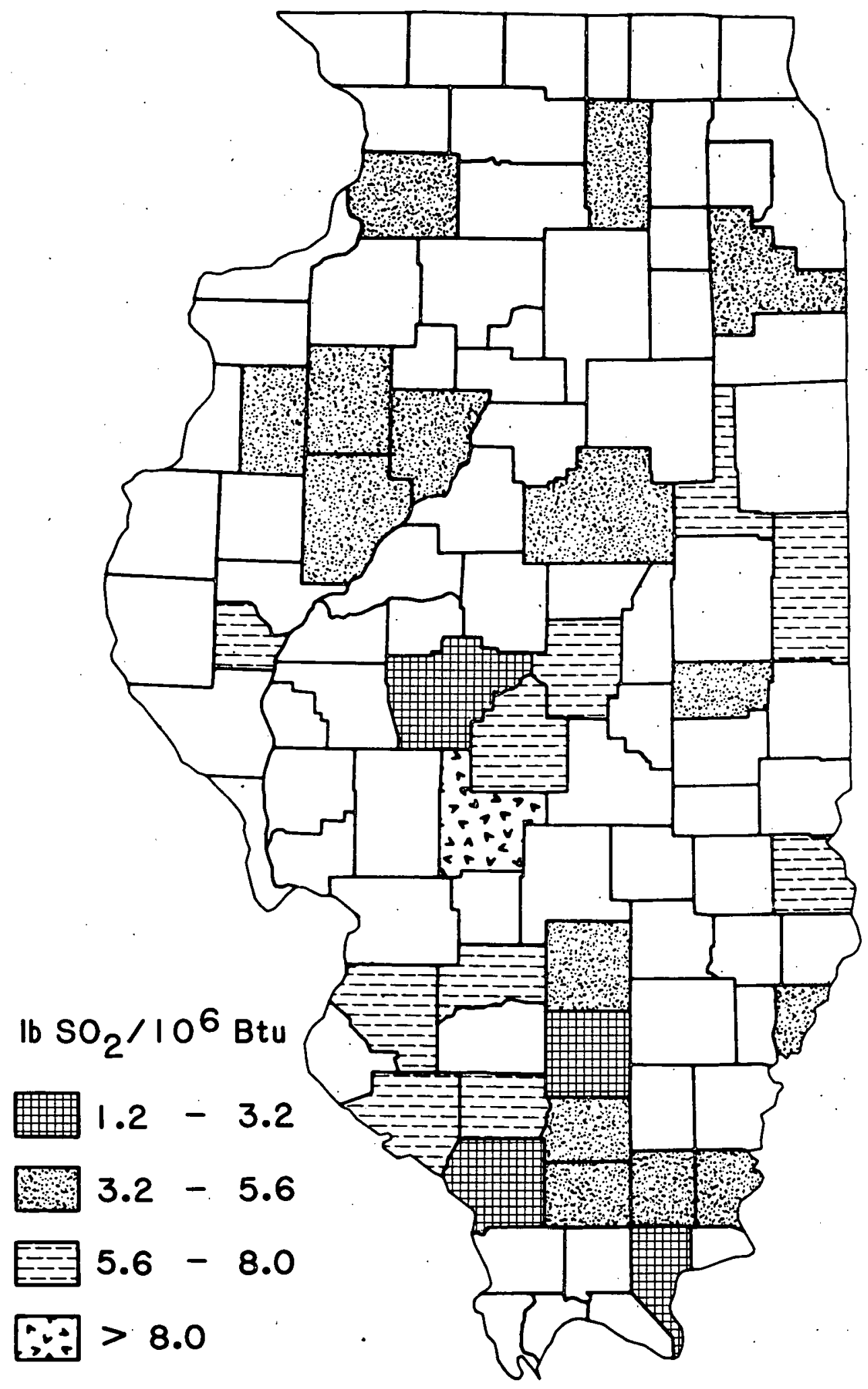

Fig. B.11 Illinois: Average Sulfur Content of Coal. 
Table B.12 Illinois: Coal Pzoduction and Reserves Tonnage

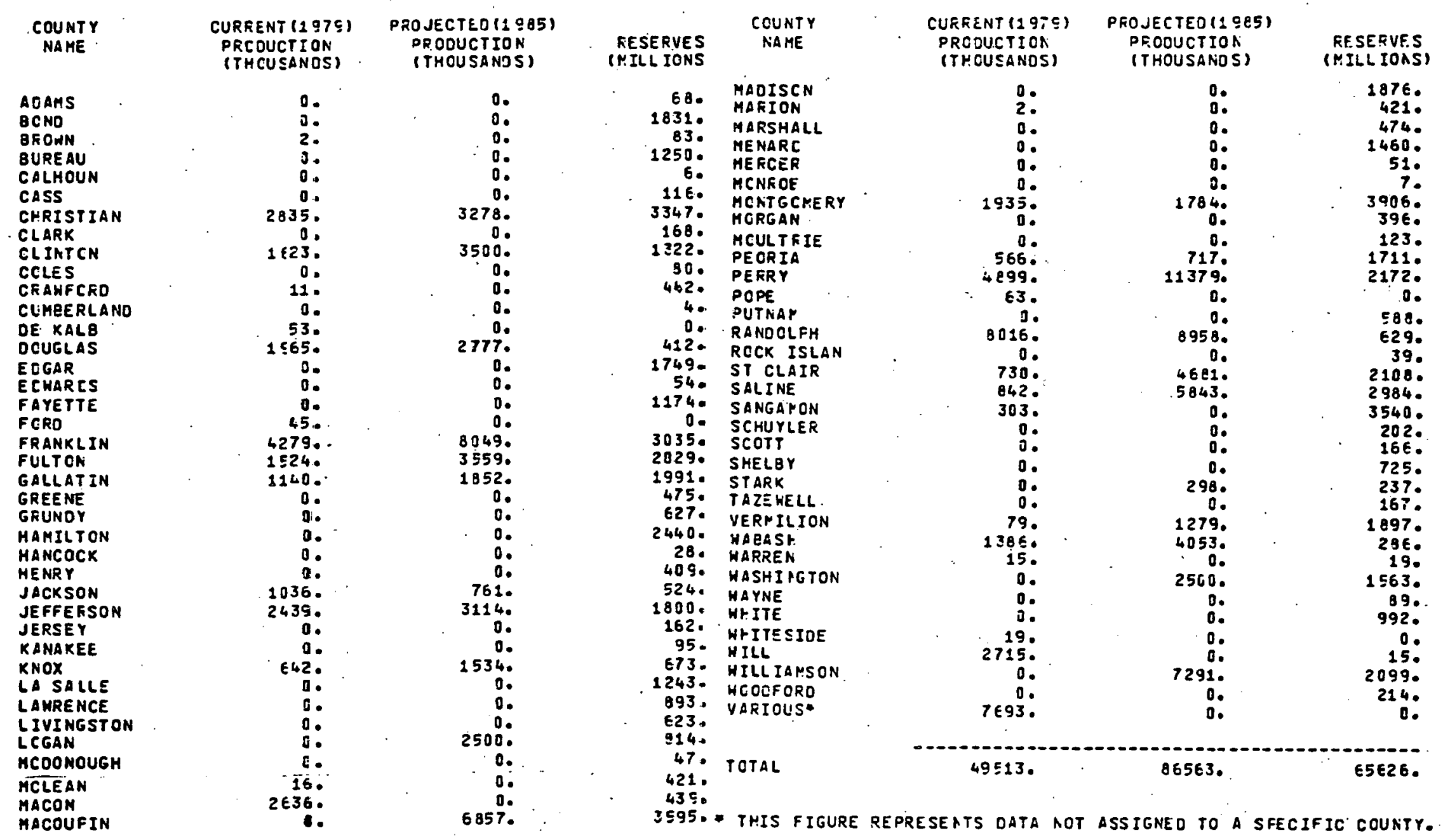




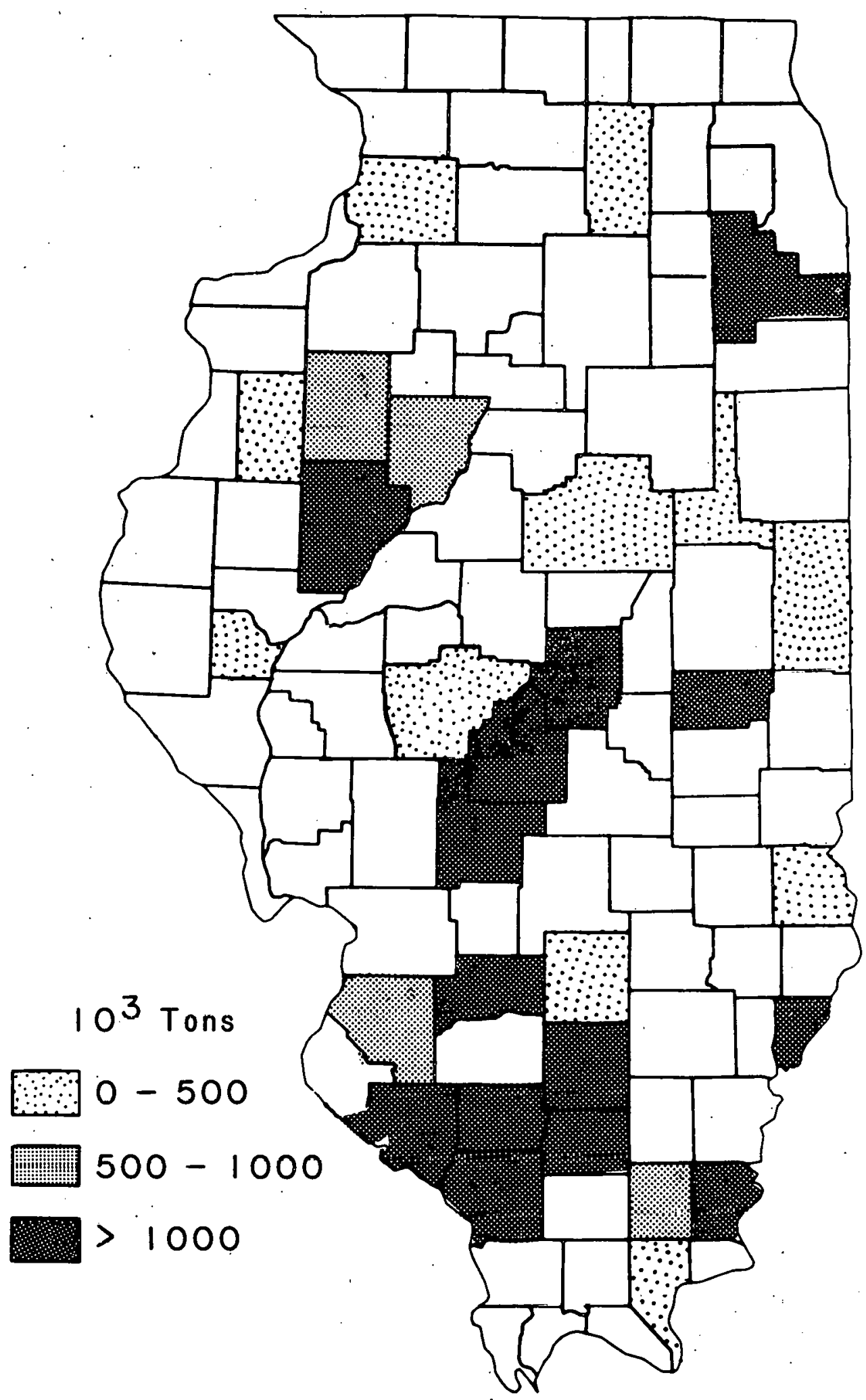

Fig. B.12 Illinois: Coal Production in 1979 
Table B.13 Indiana: Coal Quality Data

COUATY
NAMES
CASS
CLAY
DAVIESS
DUBOIS
FCUNTAIN
GIBSOR
GRANT
GREENE
JASFER
KAOX
MART IN
MCATGCRERY
PERRY
PIKE
SFENCER
SULLIVAN
VERYILLION
VIGO
HARREN
WARRICK
HAYNE
WAY

$\begin{array}{lll}\text { AVE. SO2 } & \text { AVE.ASH } & \text { AVE HEAT } \\ \text { CONTENT } & \text { CCNTENT } & \text { VALUE } \\ \text { (LSS/MBTUI } & \text { (PEFCEAT) : (BTU/LB) }\end{array}$

3.16

6.53

7.15

3.96

6.68

6.40

5.11

4.41

3.82

4.31

3.10

6.88

5.80

4.49

4.75

3.05

4.087

6.86

6.04

5.65

5.76
7.53

9. $E 1$

$13 . \in 5$

9.83

10.70

14.05

$13.3 E$

11.25

9. $C 0$

11.98

9.43

16.54

10.95

$10.0 E$

9.88

9. 26

13.42

11.44

10.75

10.51

$10.3 \mathrm{E}$
11271.

11110 .

1.6009 .

11268 .

10631 .

10447 .

10252.

$1 C 810$.

11600 .

10658 .

11084 .

0754 .

11056.

11007 .

11155 .

10877 .

10201.

10885 .

$1024 E$.

11017 .

11012 .
HASHABILITY DATA PERCENT $S$ ETU LOSS REMCVAL

(PERCENT)

$\begin{array}{rr}.06 & \ddots .00 \\ 6.51 & 2.34 \\ 15.74 & 2.13 \\ 6.91 & 2.55 \\ 22.03 & 2.40 \\ 22.33 & 1.11 \\ 37.38 & 6.62 \\ .24 & 1.04 \\ 32.6 E & 1.91 \\ 6.06 & 1.73 \\ 28.15 & 1.60 \\ 37.96 & 5.93 \\ 6.83 & .77 \\ 5.96 & .65 \\ 30.44 & 3.99 \\ 37.51 & .04 \\ 43.56 & 6.63 \\ 7.97 & 8.30 \\ 35.17 & .78 \\ 11.7 E & 2.52 \\ & 1.46\end{array}$




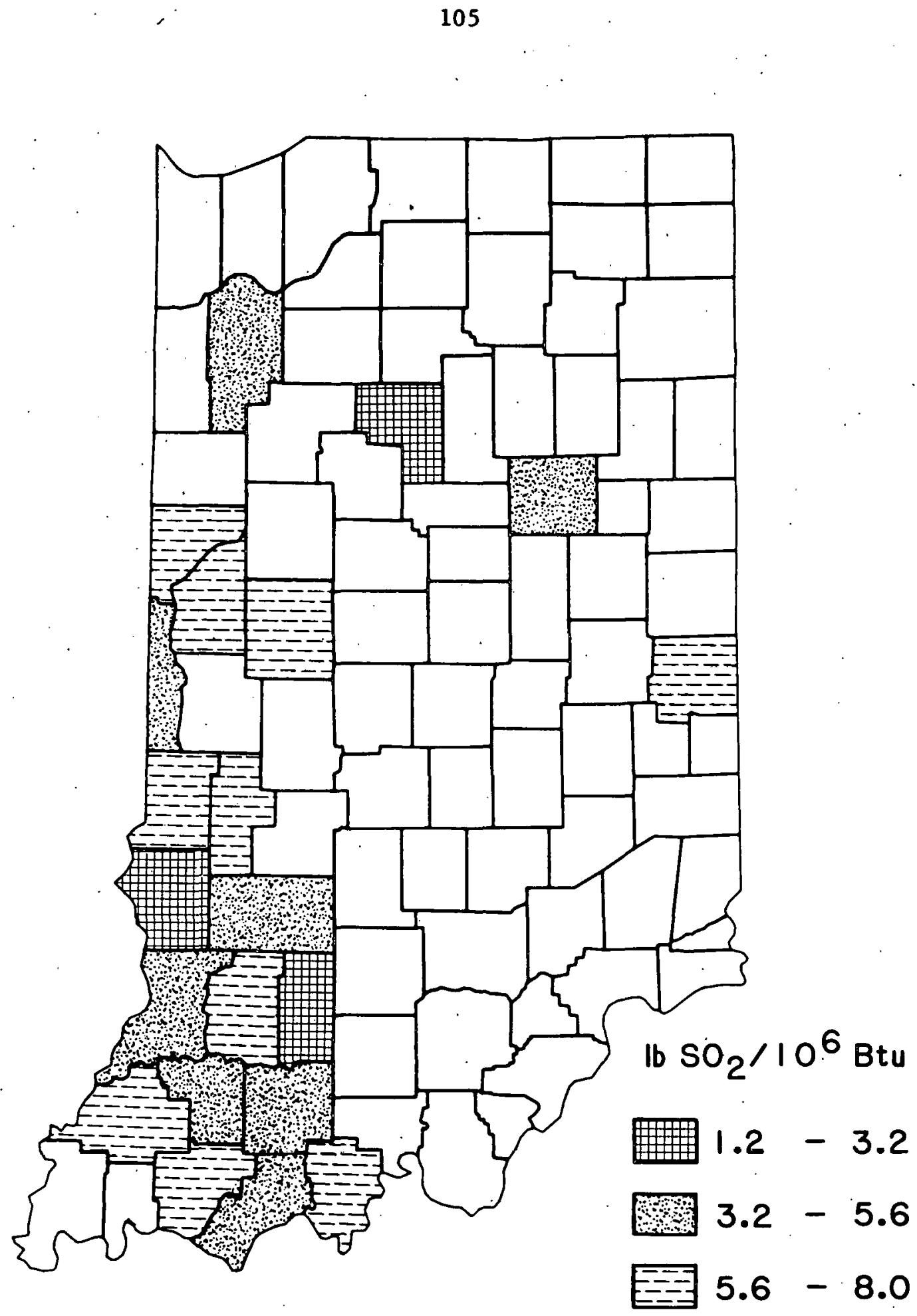

Fig. B.13 Ind lana: Average Sulfur Content of Coal 
Table B.14 Indiana: Coal Production and Reserves Tonnage

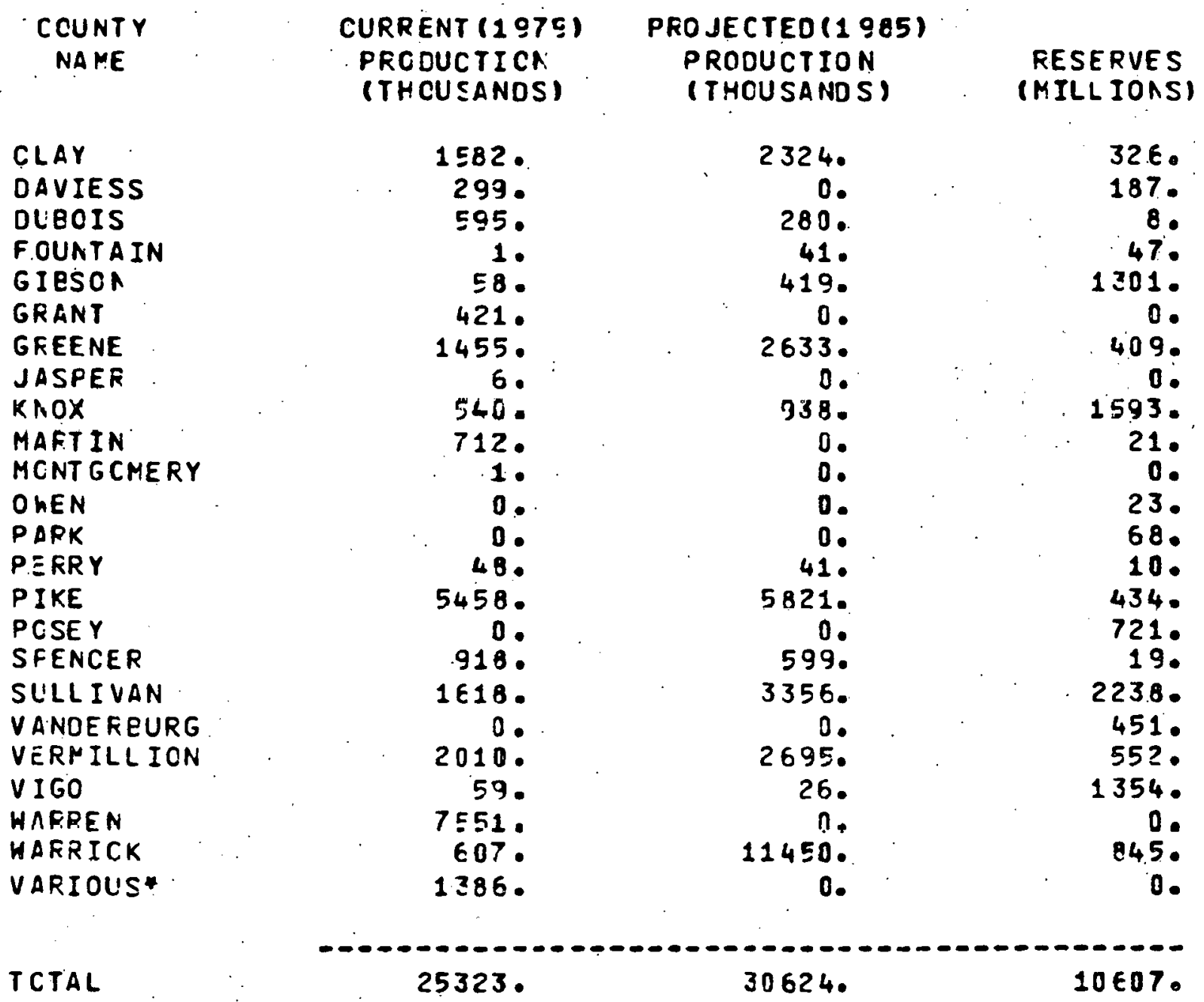

* this figure fepresents dATA nOt asSigneo to a speCific ccunty. 


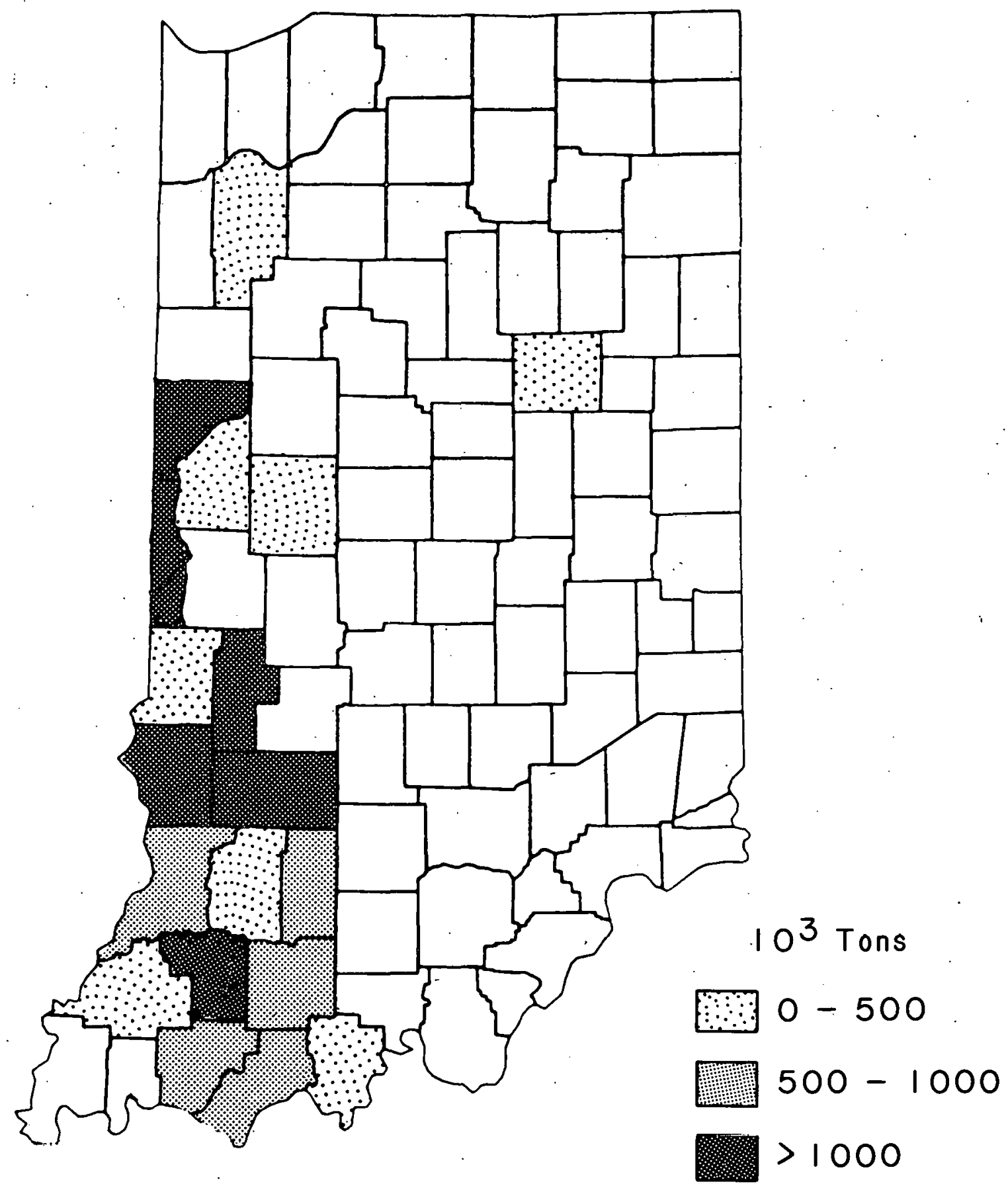

Fig. B.14 Indiana: Coal Production in 1979 
Table B.15 Iowa: Coal Quality Data

\begin{tabular}{|c|c|c|c|c|c|}
\hline $\begin{array}{l}\text { COUATY } \\
\text { NAMES }\end{array}$ & $\begin{array}{l}\text { A VE. SO2 } \\
\text { CONTENT } \\
\text { RLBS/MBTU) }\end{array}$ & $\begin{array}{l}\text { AVE. ASH } \\
\text { CONTENT } \\
\text { (PERCENT) }\end{array}$ & $\begin{array}{l}\text { AVE HEAT } \\
\text { VALUE } \\
\text { (BTU/LB) }\end{array}$ & $\begin{array}{l}\text { WASHAB } \\
\text { PEP.CEAT } S \\
\text { FEMOVAL }\end{array}$ & $\begin{array}{l}\text { ITY DATA } \\
\text { BTU LOSS } \\
\text { (PERCENT) }\end{array}$ \\
\hline $\begin{array}{l}\text { JASFEF } \\
\text { MAHASKA } \\
\text { MAKION } \\
\text { MCNFOE }\end{array}$ & $\begin{array}{r}10.39 \\
9.24 \\
7.17 \\
8.18\end{array}$ & $\begin{array}{l}15.13 \\
18.86 \\
12.39 \\
15.94\end{array}$ & $\begin{array}{l}9316 . \\
6946 . \\
9792 . \\
9533 .\end{array}$ & $\begin{array}{l}41.37 \\
45.59 \\
36.25 \\
31.58\end{array}$ & $\begin{array}{l}6.53 \\
3.51 \\
5.66 \\
4.74\end{array}$ \\
\hline
\end{tabular}




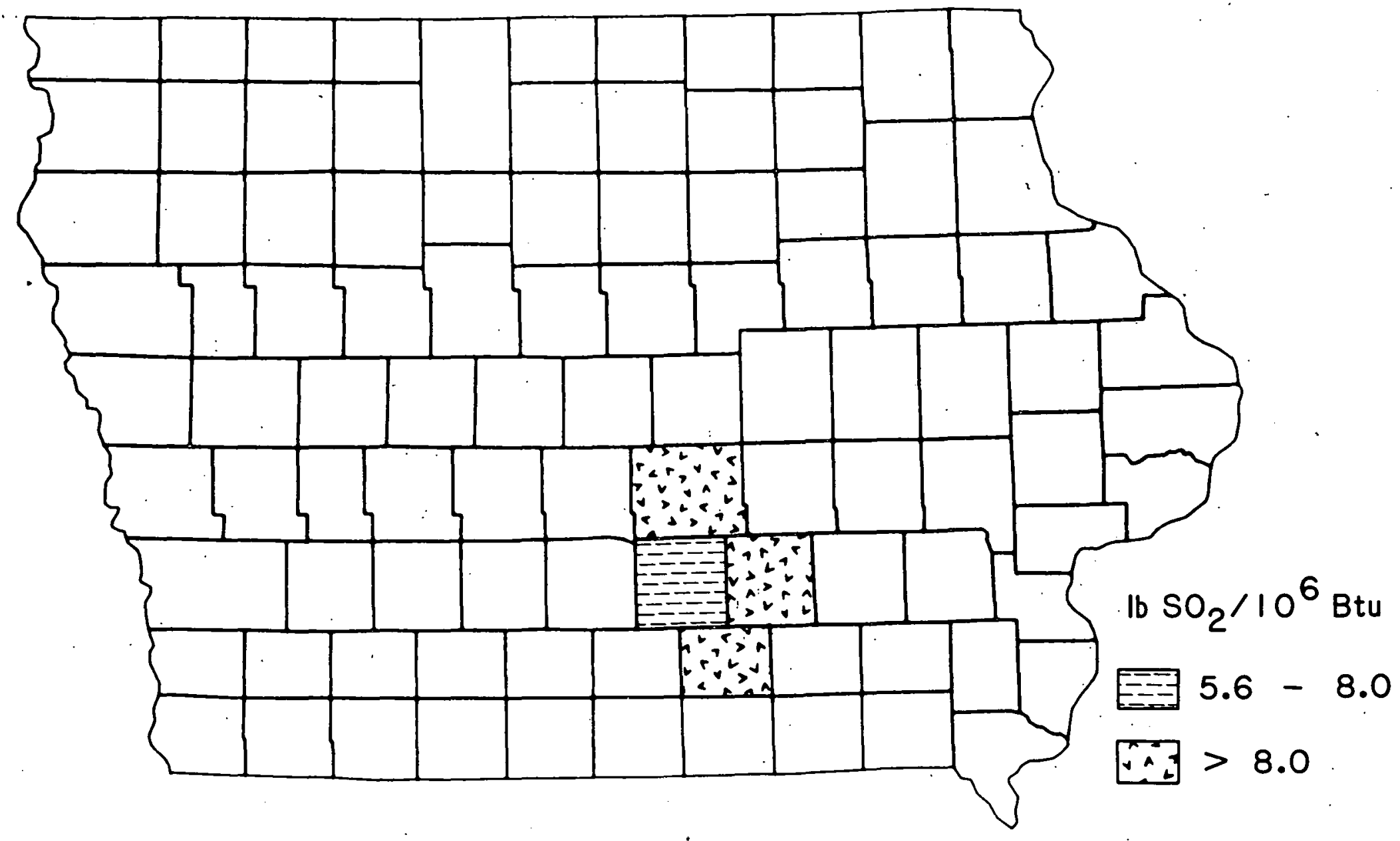

Fig. B.15 Iowa: Average Sulfur Content of Coal 
Table B.16 Iowa: Coal Production and Reserves Tonnage

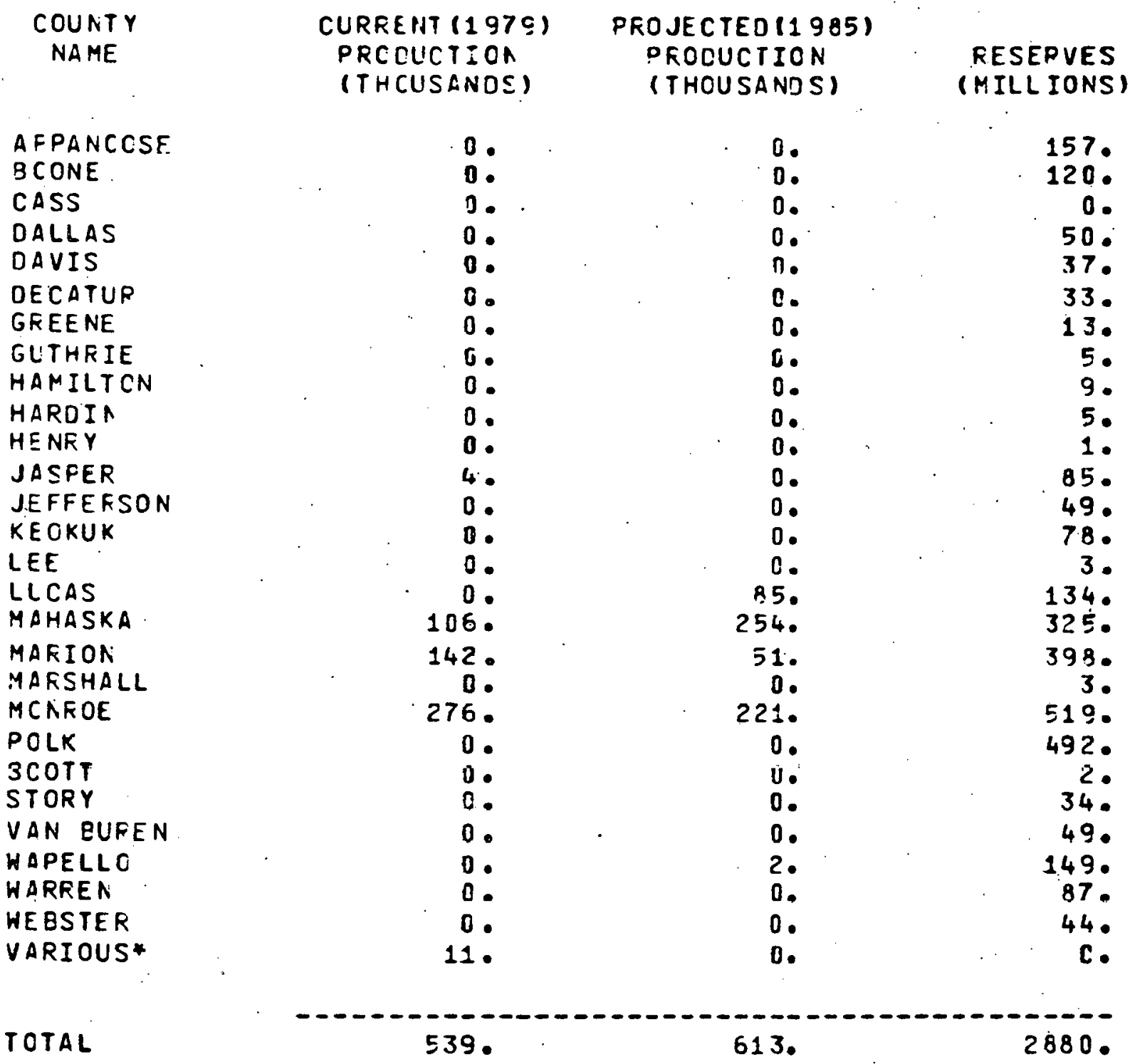

* this figure fiepre sents data not assigned to a sfecific ccunty. 


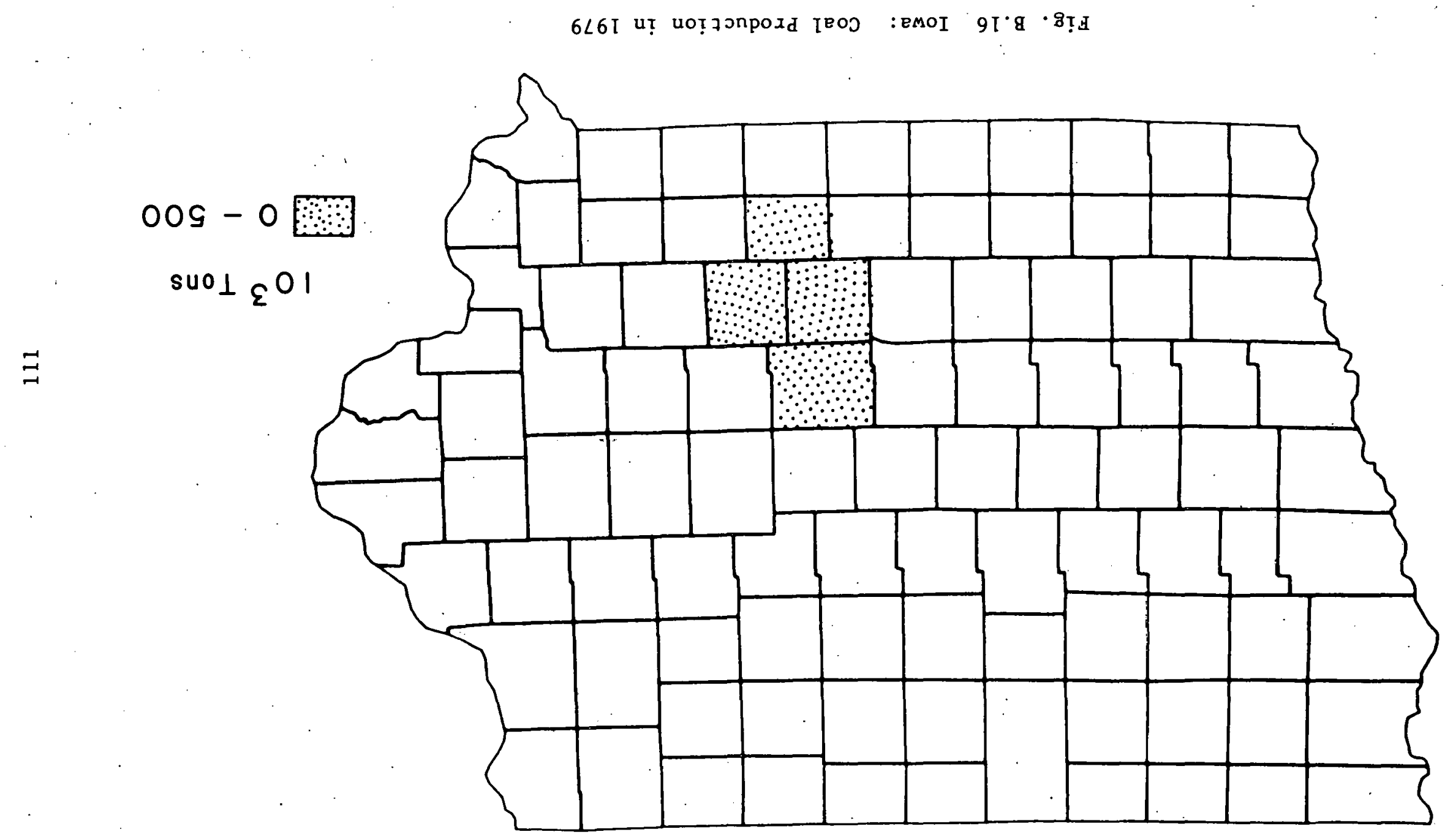


Table B.17 Kansas: Coal Quality Data

COUNTY
NAMES
CHASE
CRAWFCRO
GEARY
NEMAHA

$$
\begin{aligned}
& \text { A VE, } \mathrm{SO} 2 \\
& \text { CONTENT } \\
& \text { (LES/MBTU) }
\end{aligned}
$$

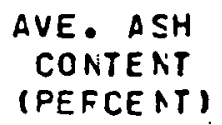

6.44

5.83

2.22

6.69

15.32
11.50
7.00
18.98

15.32

7.00

11706.

12464 .

13500 .

10792 .
KASHABIL ITY DATA

FERCENT S RTU LOSS

REMCVAL

(PEPCENT)

$$
2.92
$$

1.27 .

32.29

20.72
.75

.23

4.98

6.26 


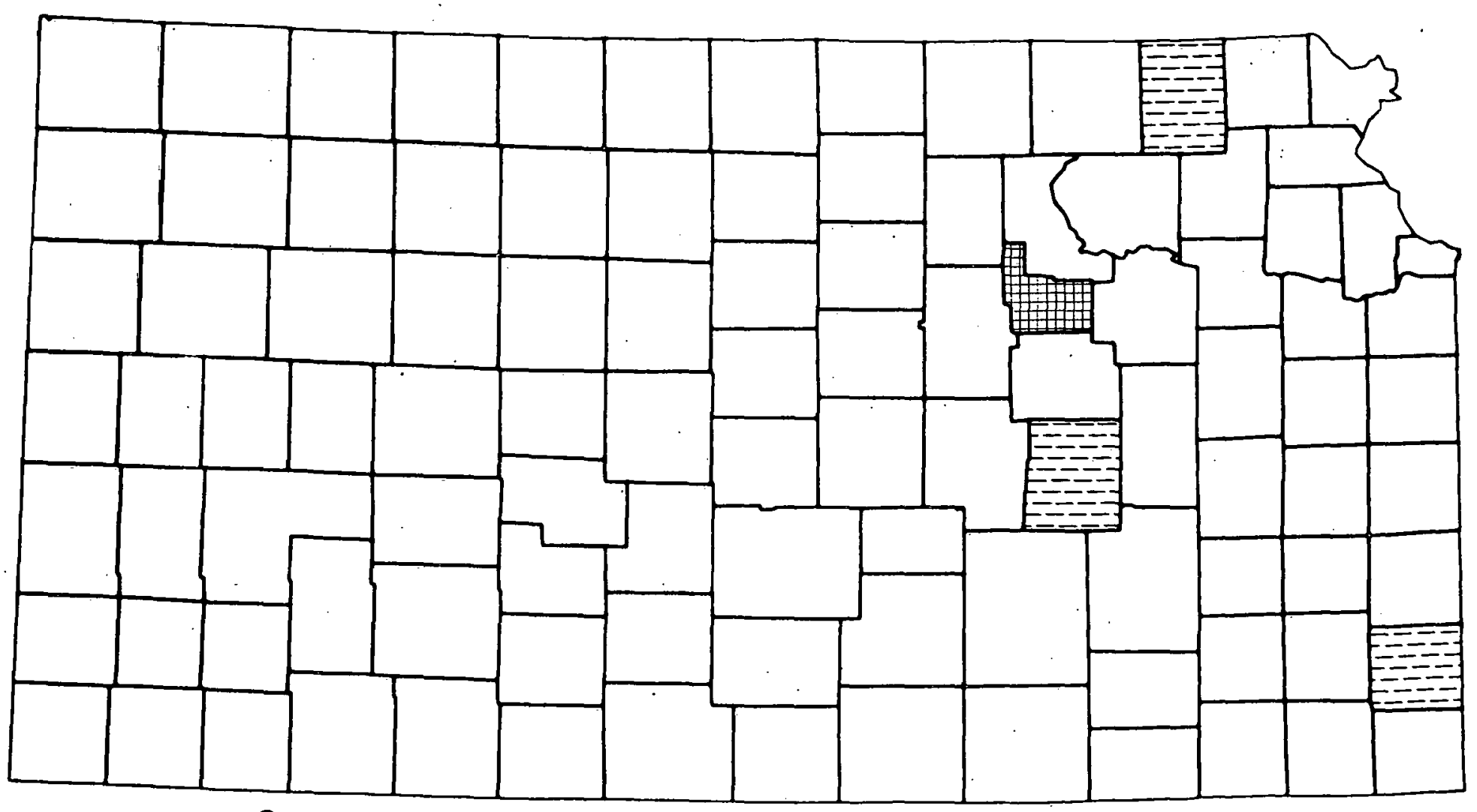

Ib $\mathrm{SO}_{2} / 10^{6} \mathrm{Btu}$

$1.2-3.2$

E- $5.6-8.0$

Fig. B.17 Kansas: Average Sulfur Content of Coal 
Table B.18 Kansas: Coal Production and Reserves Tonnage

COUNTY

NAME

ATCHISCN

BCUKBON

BROWN

CHEROKEE

CCWLEY

CRAHFCRD

FFANKLIN

LABETTE

LEAVENWORT

LINN

NERAHA

OSAGE

WILSON

TCTAL
CURRENT (1979) PROJECTED(1985)

PROOUCTION

(THCUSANCS)
RESERVES

(MILLIONS)

PROOUCTION

(THCUSANDS)
D. 0.

412 . 392.

0.0 .

D. 8.

$0 . \ldots 0$.

133.917.

$0 . \quad 0$.

0.1500 .

0.00.

D. 0 :

11. 0.

$0 . \quad 0$.

D. B.
6.

259.

13.

236.

5.

300

1.

C.

19.

474.

4.

70 .

0. 


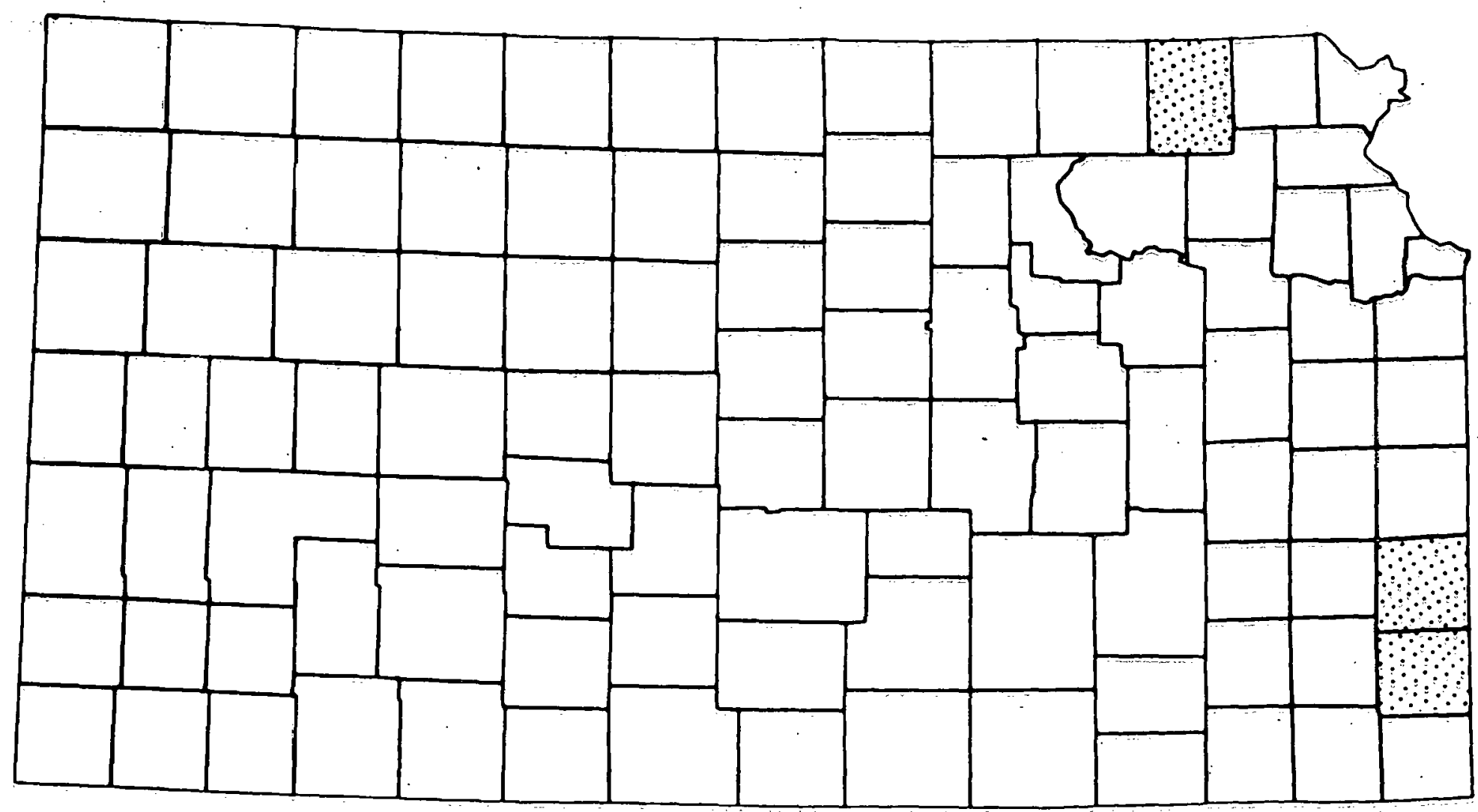

$$
\begin{aligned}
& 10^{3} \text { Tons } \\
& 0-500
\end{aligned}
$$

Fig. B.18 Kansas: Coal Production in 1979 
Table B.19 Rentucky: Coal Quality Data

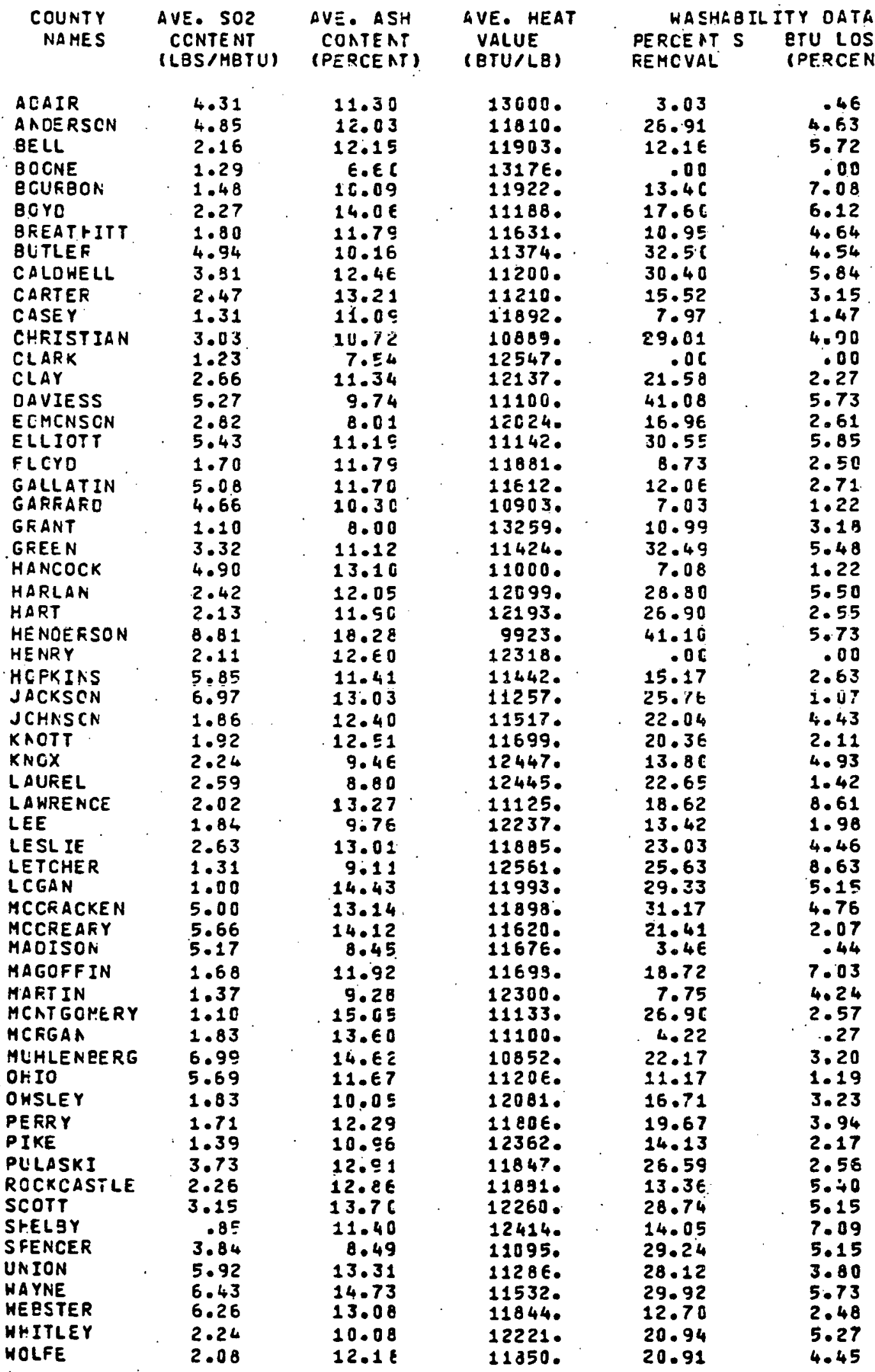


Ib $\mathrm{SO}_{2} / 10^{6} \mathrm{Btu}$

$\begin{array}{lll}0 & -1.2 & E-6-8.0 \\ 1.2 & -3.2 & \square .9 \\ 3.2 & -5.6 & \end{array}$

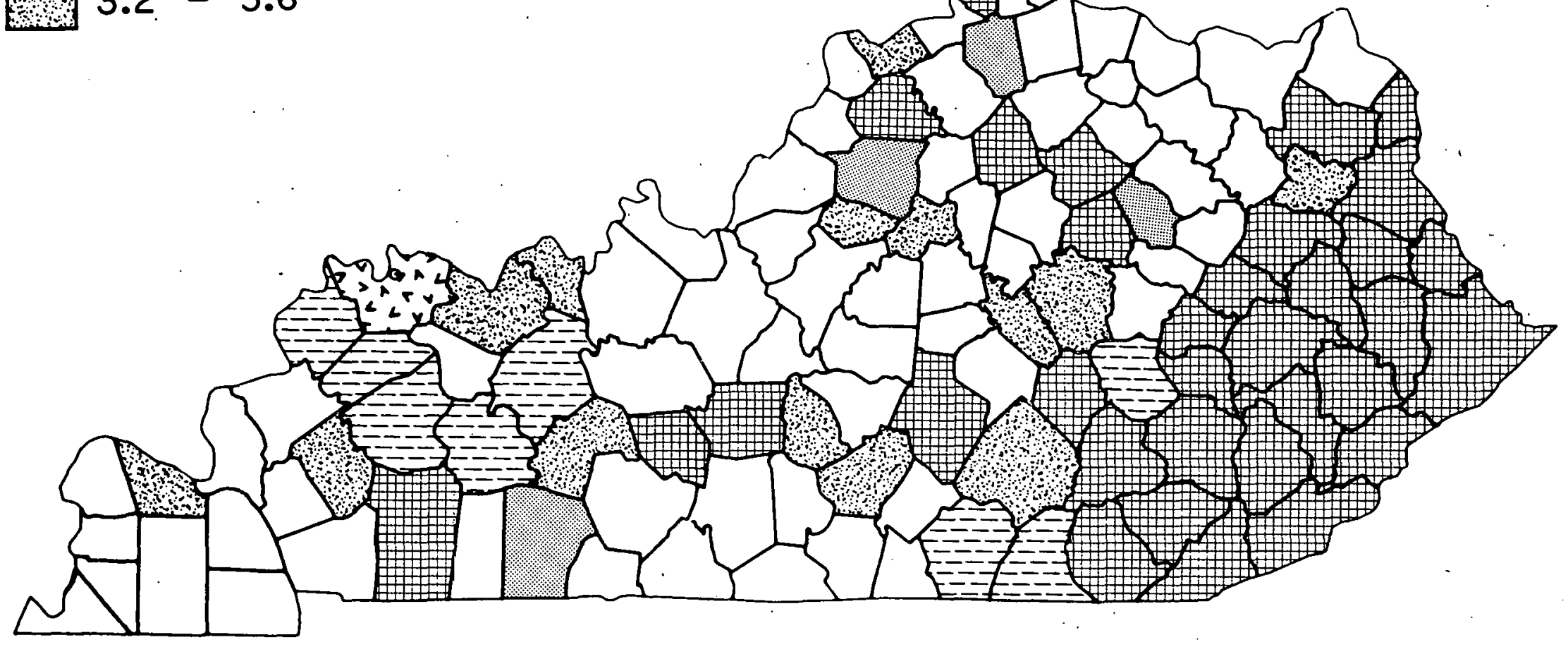

Fig. B.19 Kentucky: Average Sulfur Content of Coal 
Table B.20 Kentucky: Coal Production and Reserves Tonnage

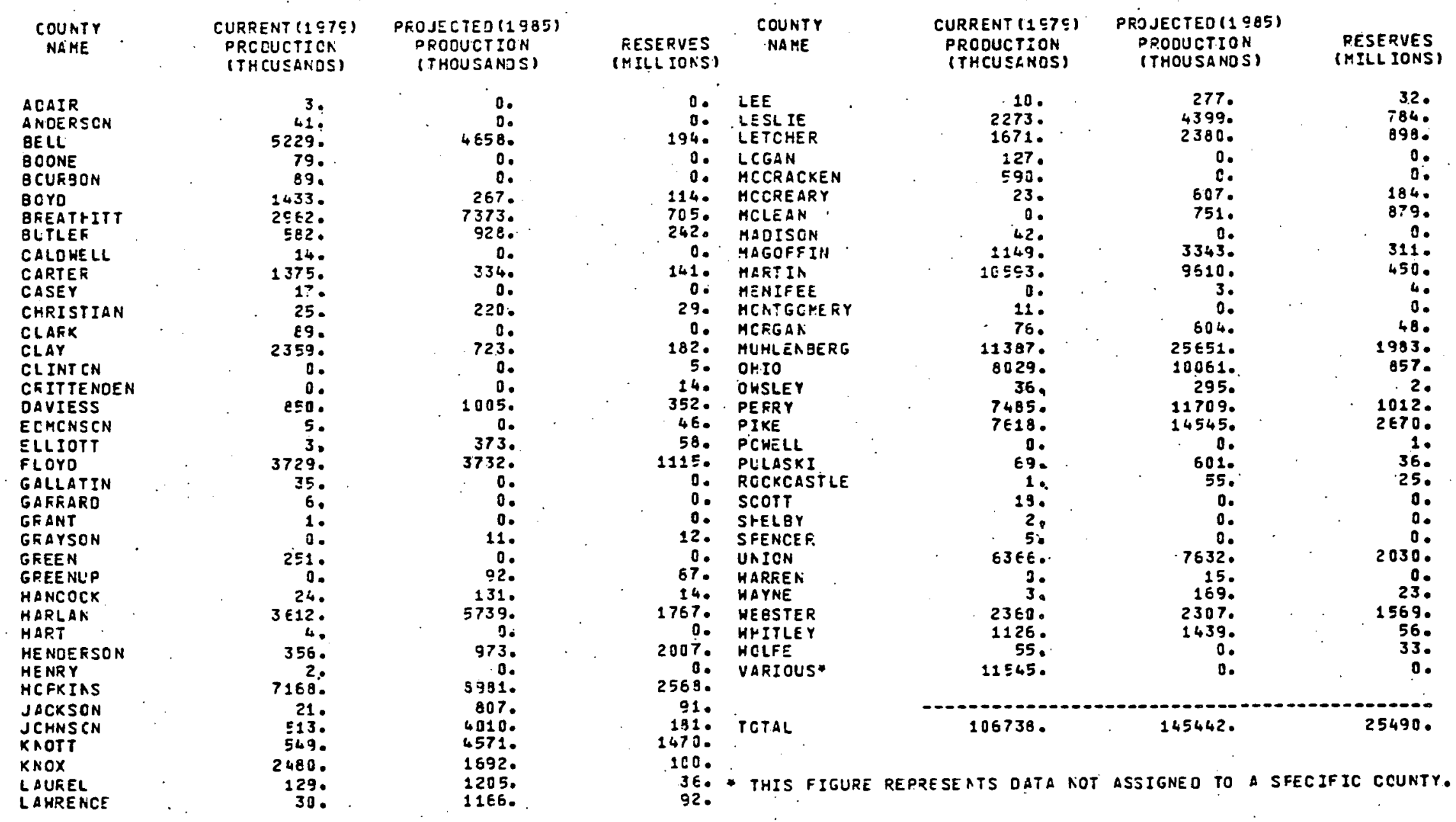




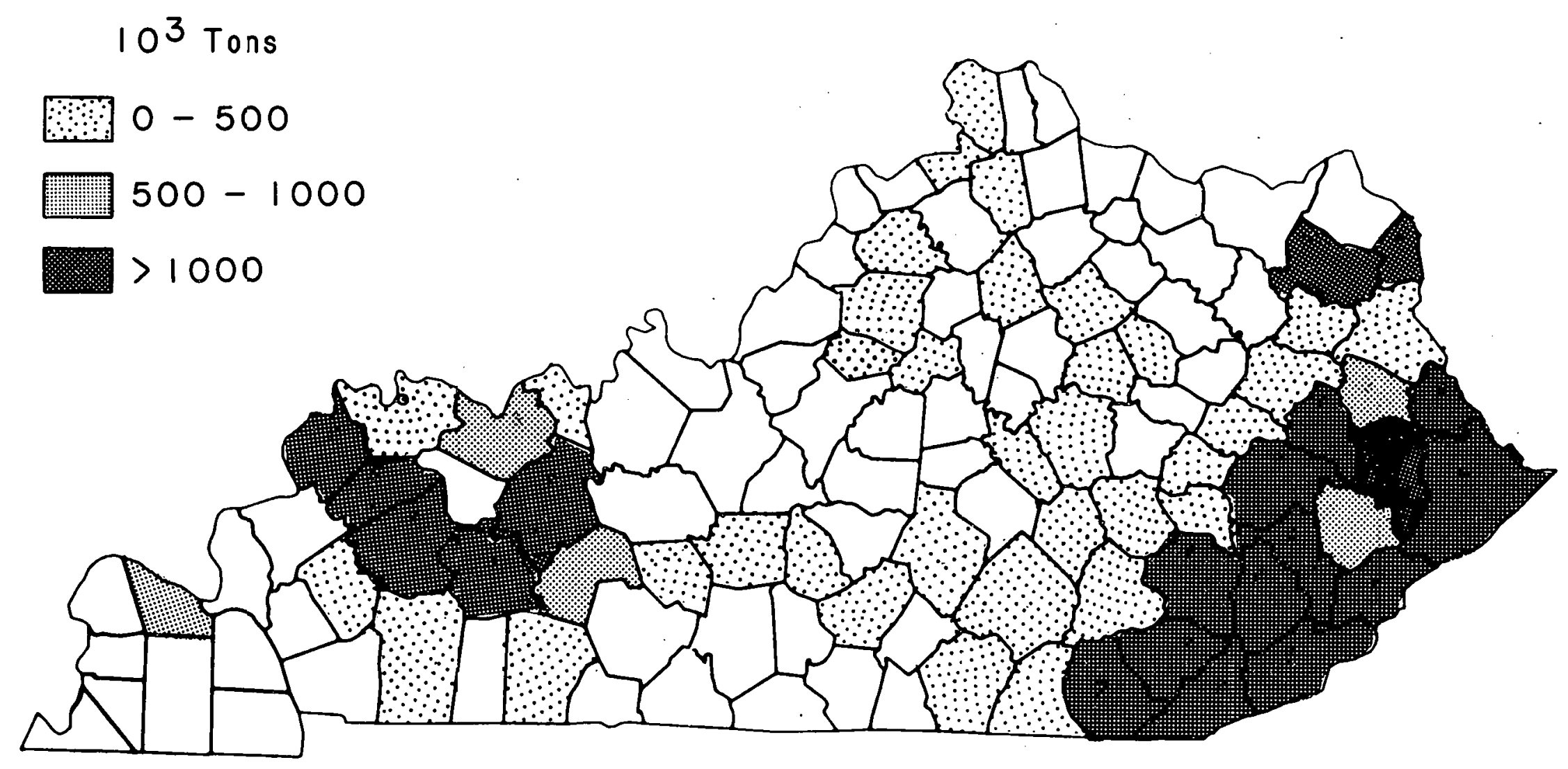

Fig. B.20 Kentucky: Coal Production in 1979 
Table B.21 Maryland: Coal Quality Data

\section{COUNTY NAMES}

$$
\begin{aligned}
& \text { A VE. SOL } \\
& \text { CONTENT } \\
& \text { (LSSIMSTU) }
\end{aligned}
$$

\author{
AVE. ASH \\ CCNTEAT \\ (PERCEAT)
}

2.58

2.80

2.13

\begin{abstract}
14.37
$1.4 . E \bar{C}$

10.50
\end{abstract}

ALLEGANY

MCNTGCHERY

$$
\begin{aligned}
& \text { QVE HEAT } \\
& \text { VALUE } \\
& \text { (BTU/LS) }
\end{aligned}
$$

\begin{abstract}
11841.
11915.

12191.
\end{abstract}

WASHABIL IT Y. DATA FERCEAT S: BTU LOSS FEMOVAL (PERCENT)

$\begin{array}{rr}29.12 & 11.91 \\ 28.80 & 4.78 \\ 12.57 & 2.69\end{array}$




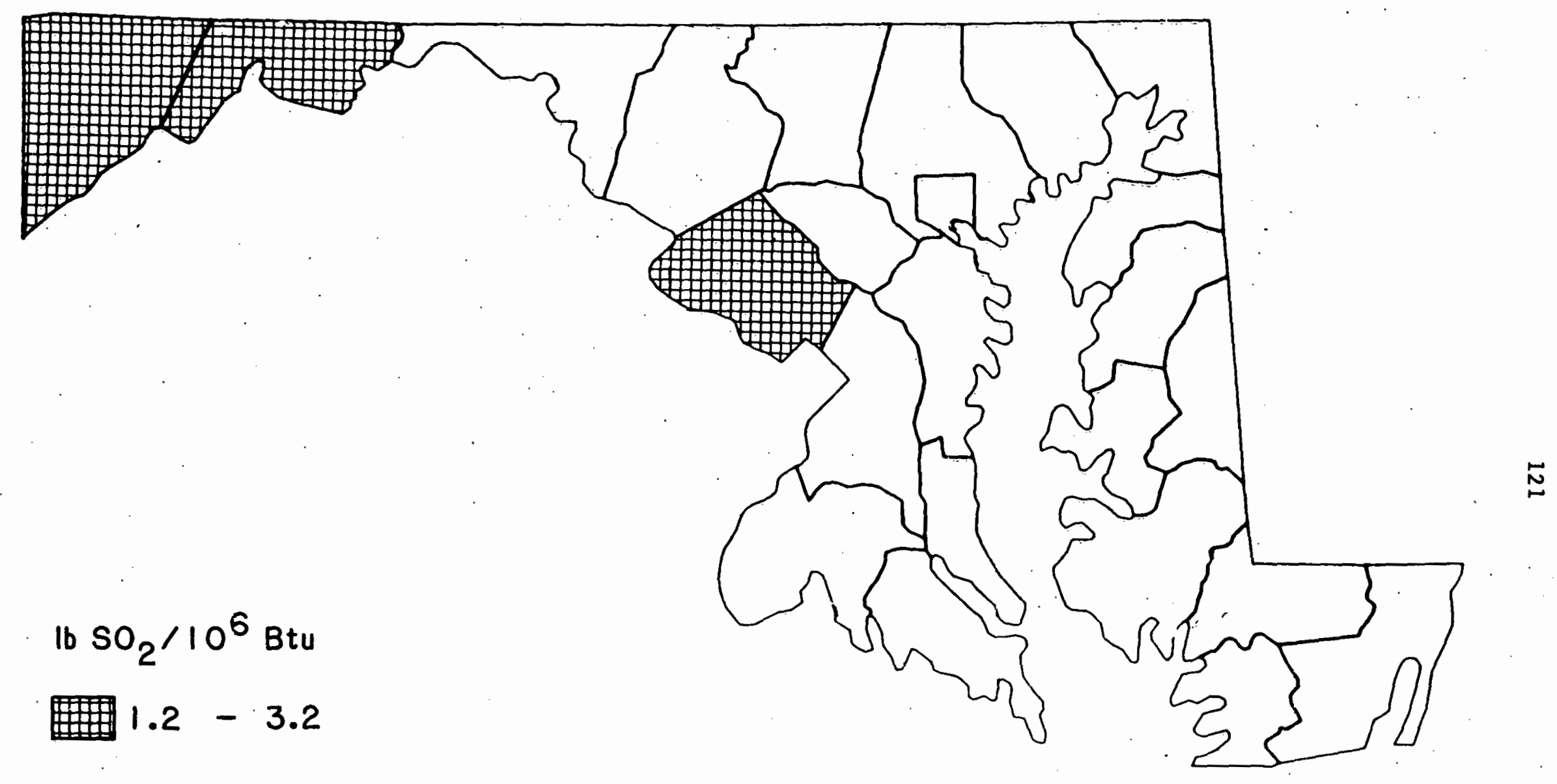

Fig. B.2l Maryland: Average Sulfur Content of Coal 
Table B.22 Maryland: Coal Production and Reserves Tonnage

\section{COUNTY \\ NAME}

\begin{abstract}
ALLEGANY GAFRETT

MCNT GCMERY

VARIOUS*
\end{abstract}

TCTAL

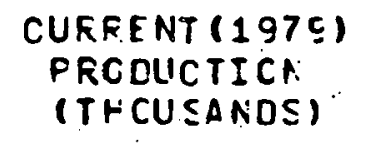

CURFENT (197C)

(THCUSANDS)

\section{FFO JECTEO (1985)}

PRODUCTION

(THCUSANOS) -
RESERVES

(NILL IONS)

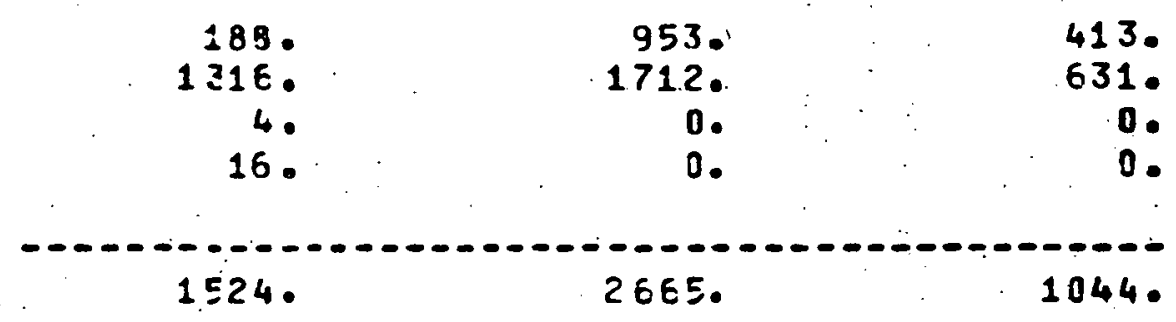

* this figure repeesents oata not assigneo to a sfecific countr. 


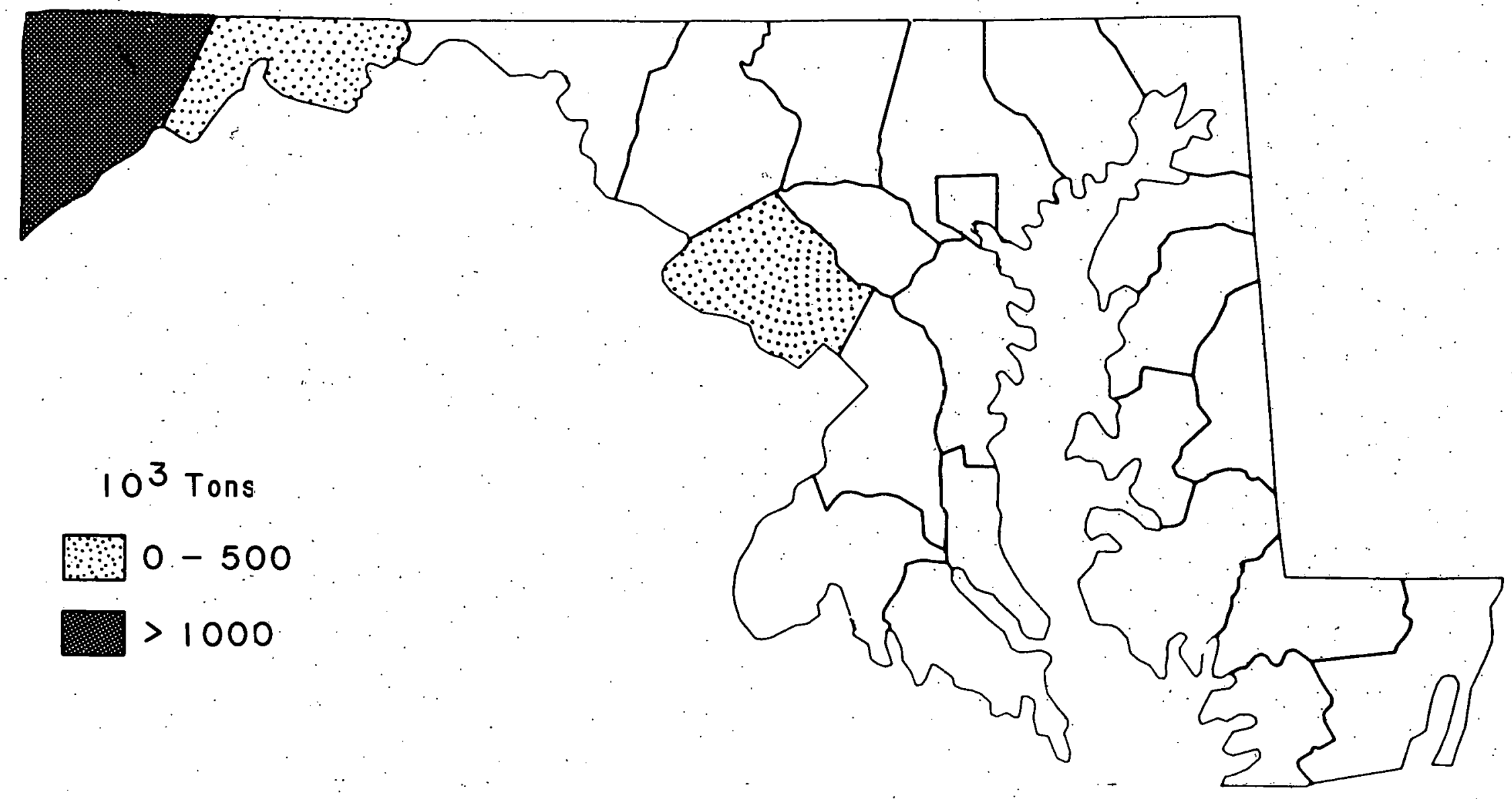

Fig. B.22 Maryland: Coal Production in 1979 
Table B.23 Missouri: Coal Quality Data

\begin{tabular}{|c|c|c|}
\hline $\begin{array}{l}\text { COUNTY } \\
\text { NAMES }\end{array}$ & $\begin{array}{l}\text { A VE, SOL } \\
\text { CONTENT } \\
\text { (LSS/MBTU) }\end{array}$ & $\begin{array}{l}\text { AVE D ASH } \\
\text { CONTENT } \\
\text { IPERCEAT }\end{array}$ \\
\hline $\begin{array}{l}\text { AUORAIN } \\
\text { BARTON } \\
\text { BOONE } \\
\text { CCCPEF } \\
\text { HENRY } \\
\text { HCWARD } \\
\text { MACON }\end{array}$ & $\begin{array}{r}8.76 \\
9.04 \\
7.56 \\
6.38 \\
11.46 \\
7.86 \\
8.10\end{array}$ & $\begin{array}{l}14.56 \\
22.22 \\
12.36 \\
14.35 \\
22.13 \\
14.54 \\
12.52\end{array}$ \\
\hline $\begin{array}{l}\text { PUTNAP } \\
\text { RANDOLFH } \\
\text { VERNON }\end{array}$ & $\begin{array}{l}6.29 \\
9.61 \\
7.81\end{array}$ & $\begin{array}{l}10.48 \\
17.14 \\
11.86\end{array}$ \\
\hline
\end{tabular}
AVE. HEAT
VALUE
(ETU/LB)

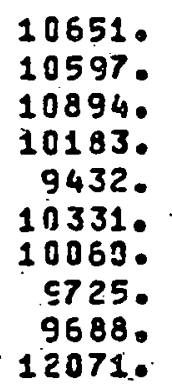

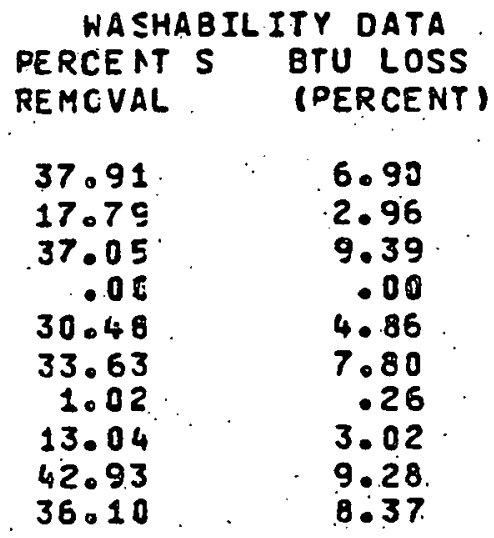




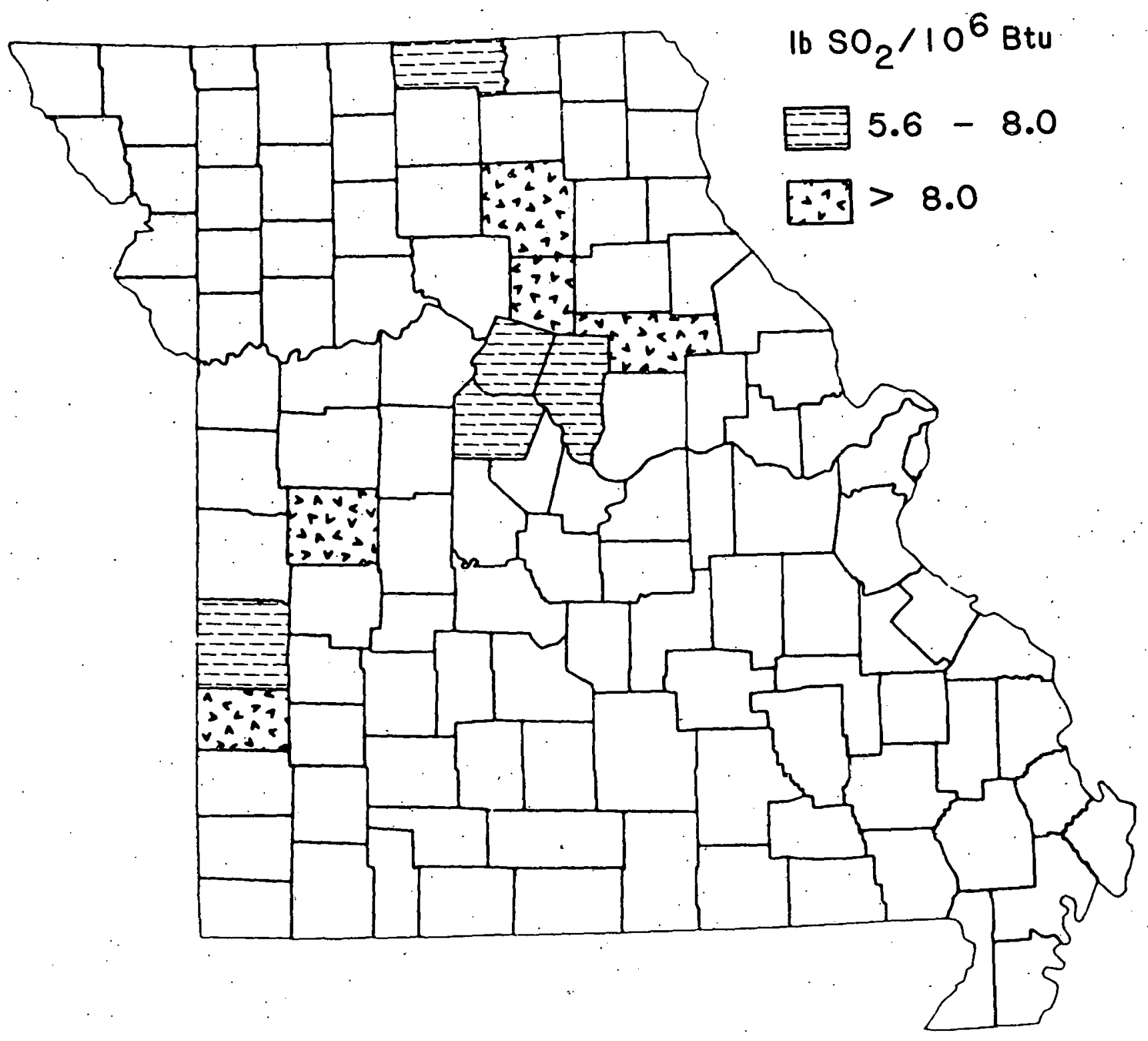

in

Fig. B.23 Missouri: Average Sulfur Content of Coal 
Table B.24 Missouri: Coal Production and Reserves Tonnage

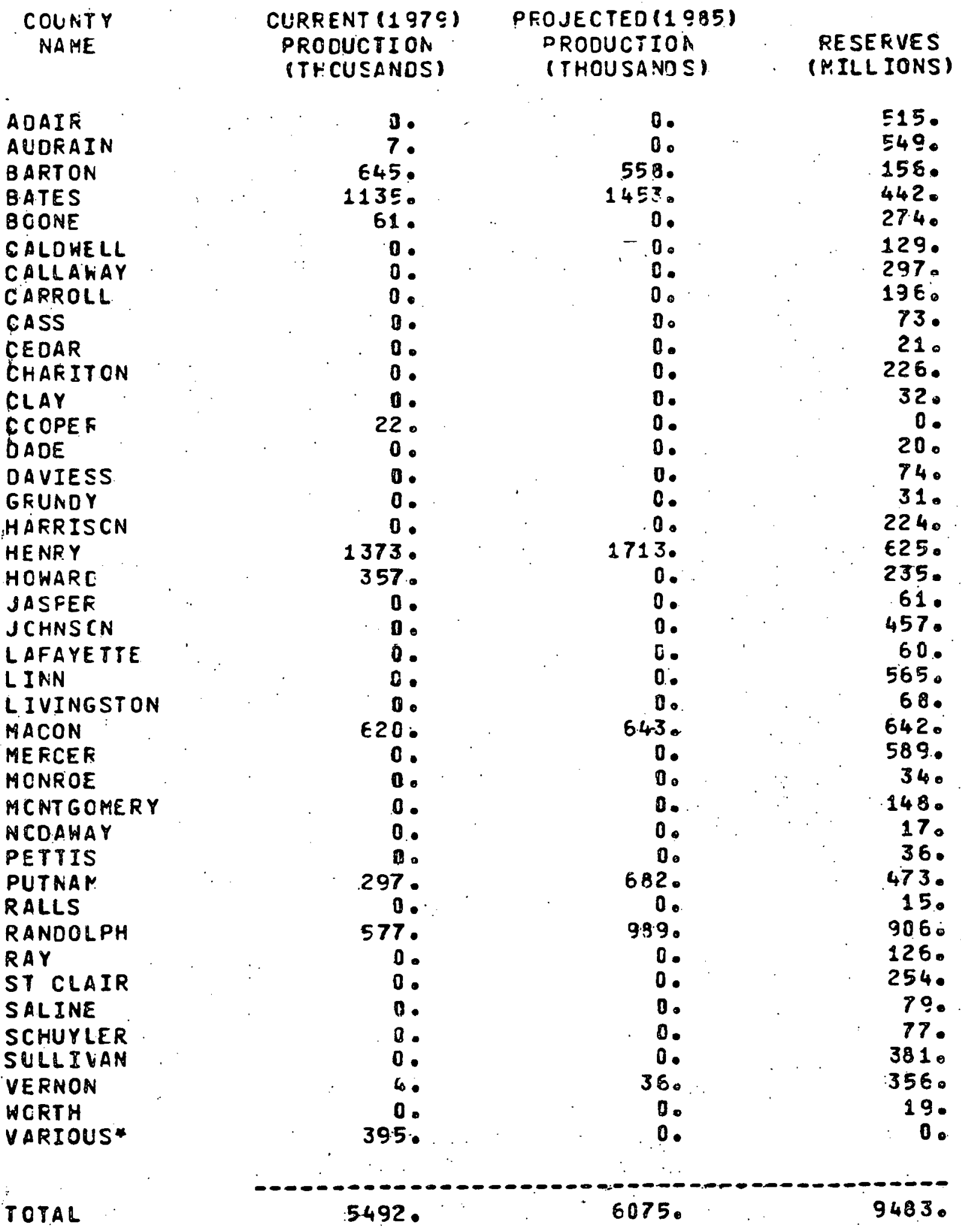

* thIS figure represents oAta not assigned to a sfecific courty. 


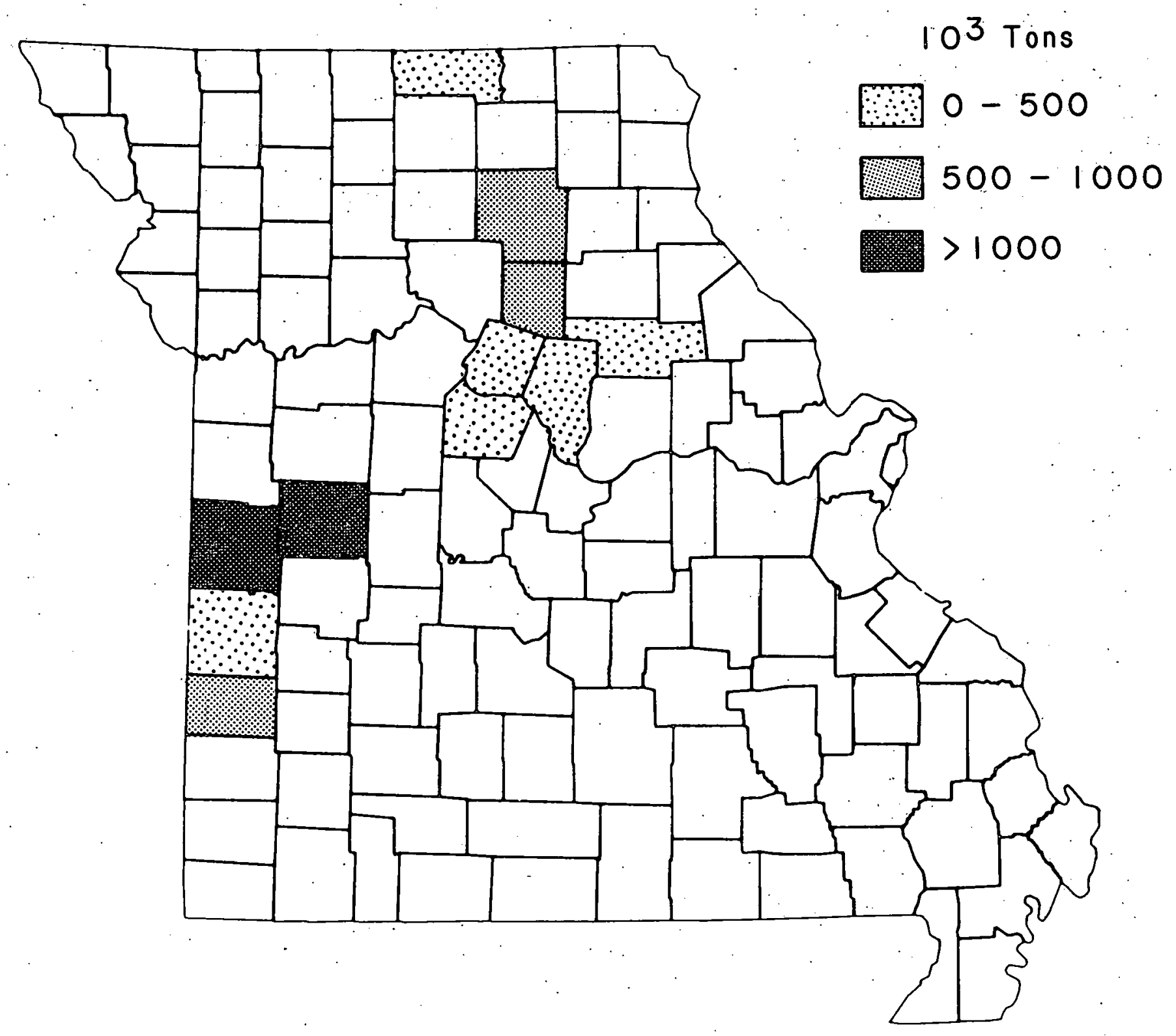

Fig. B.24 Missouri: Coal Production in 1979 
Table B.25 Montana: Coal Quality Data

\begin{tabular}{|c|c|c|c|}
\hline $\begin{array}{l}\text { COUNTY } \\
\text { NAMES }\end{array}$ & $\begin{array}{l}\text { AVE. SOL } \\
\text { CCNTENT } \\
\text { (LBS/MBTU) }\end{array}$ & $\begin{array}{l}\text { AVE } \triangle S H \\
\text { CONTENT } \\
\text { (PERCEAT) }\end{array}$ & $\begin{array}{l}\text { AVE. HEAT } \\
\text { VALUE } \\
\text { (פTU/LB) }\end{array}$ \\
\hline
\end{tabular}

\section{BIG HCRN}

BLAINE

CASCADE MUSSE LSHEL

RICHLAND

ROSEBUO

$$
\begin{array}{r}
1.17 \\
.84 \\
.81 \\
.70 \\
1.46 \\
1.82
\end{array}
$$

\begin{abstract}
9163. $94750^{\circ}$

9629.

9470 .

E502.

8746 .
\end{abstract}

WASHAGIIITY DATA

FERCENT S BTU LOSS
REMCVAL

$$
\begin{aligned}
& 36.32 \\
& 35.73 \\
& 37.00 \\
& 37.06 \\
& 34.14 \\
& 48.04
\end{aligned}
$$

2.57

2.27

2.55

2. 54

2.75

1.74 
$\therefore \quad \therefore \quad \cdots \quad l$ b SO $2 / 10^{6}$ Btu

$$
\begin{aligned}
& \square 0-1.2 \\
& \square 1.2-3.2
\end{aligned}
$$

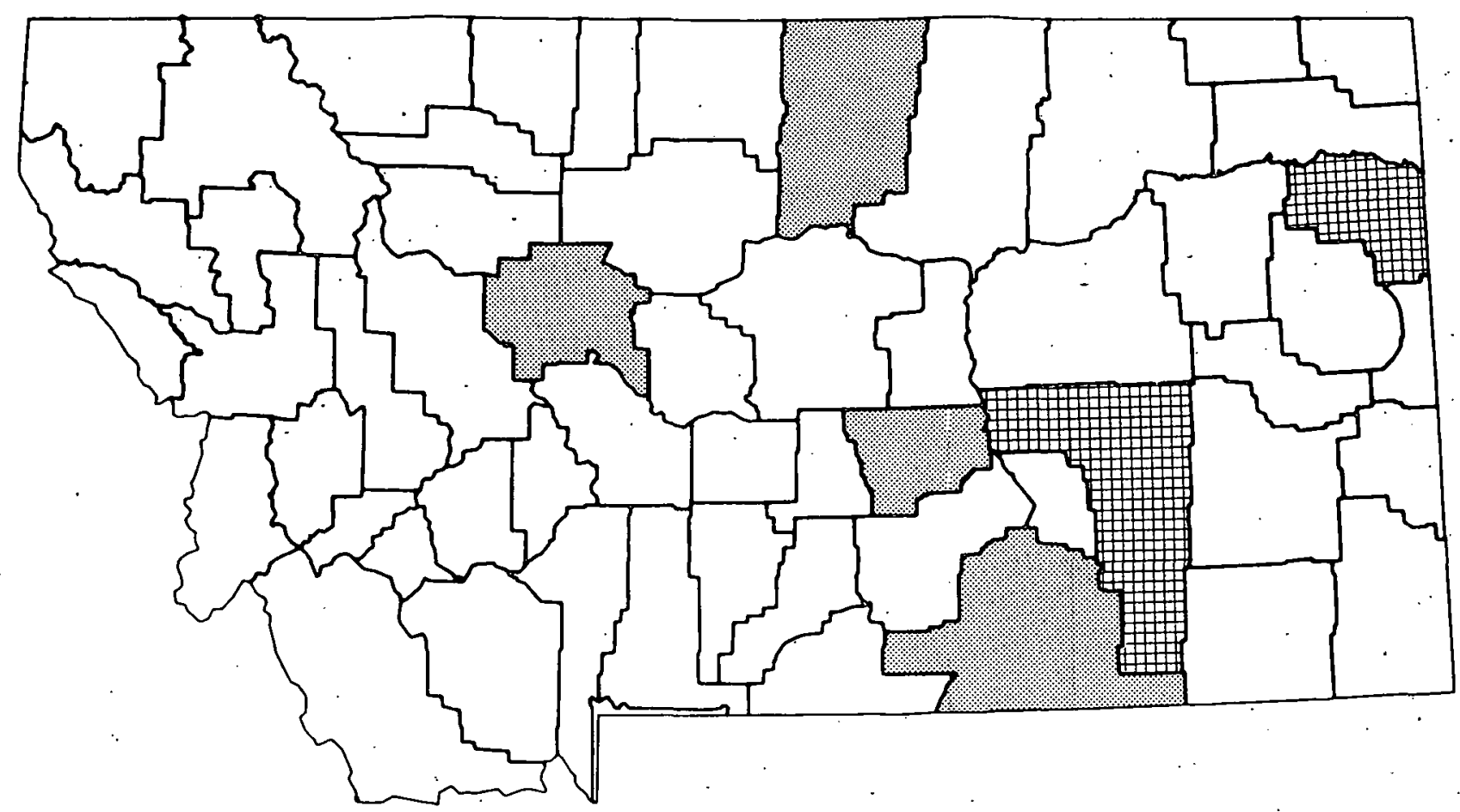

Fig. B.25 Montana: Average Sulfur Content of Coal 
Table B.26 Montana: Coal Production and Reserves Tonnage

$$
\begin{aligned}
& \text { COUNTY } \\
& \text { NARE }
\end{aligned}
$$

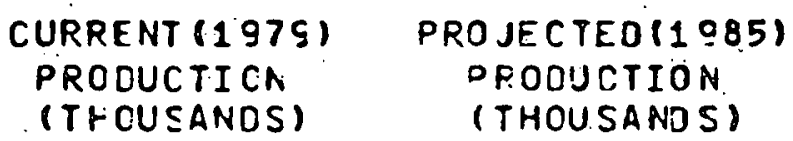

10518. 2756 .

0 .

0 。

0 .

0 .

0 .

0 .

0.

0 .

D.

0 .

0 .

D。

0.

D.

D.

0 .

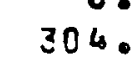

0. 12424 .

ROSEBUD

SHERIDAN

ST ILLWATER

TREASURE

W.IBAUX

YELL OWSTON

VARIOUS*
0.

D.

0.

0 .

0 .

1752 .
DPOOUCTION
(THOUSANDS)
46035

RESERVES
(MILLIONS)

38355.

18.

0.

0 .

0 .

0 .

0 .

0 .

0 .

0 .

0 .

D.

o.

0 .

3000 .

0 .

2019.

2 .

D.

302.

0 .

23615.

0 。

0 .

0 .

0 .

0 .

0.
735 .

30.9

1.

$3684^{\circ}$

1102 .

150 .

210.

137.

25.

30 .

1167.

27813 .

200 .

876.

431.

26264 .

454.

1304.

10.00 .

590.

0 .
3467 .

TOTAL 
$\therefore \quad 10^{3}$ Tons

$0-500$

$>1000$

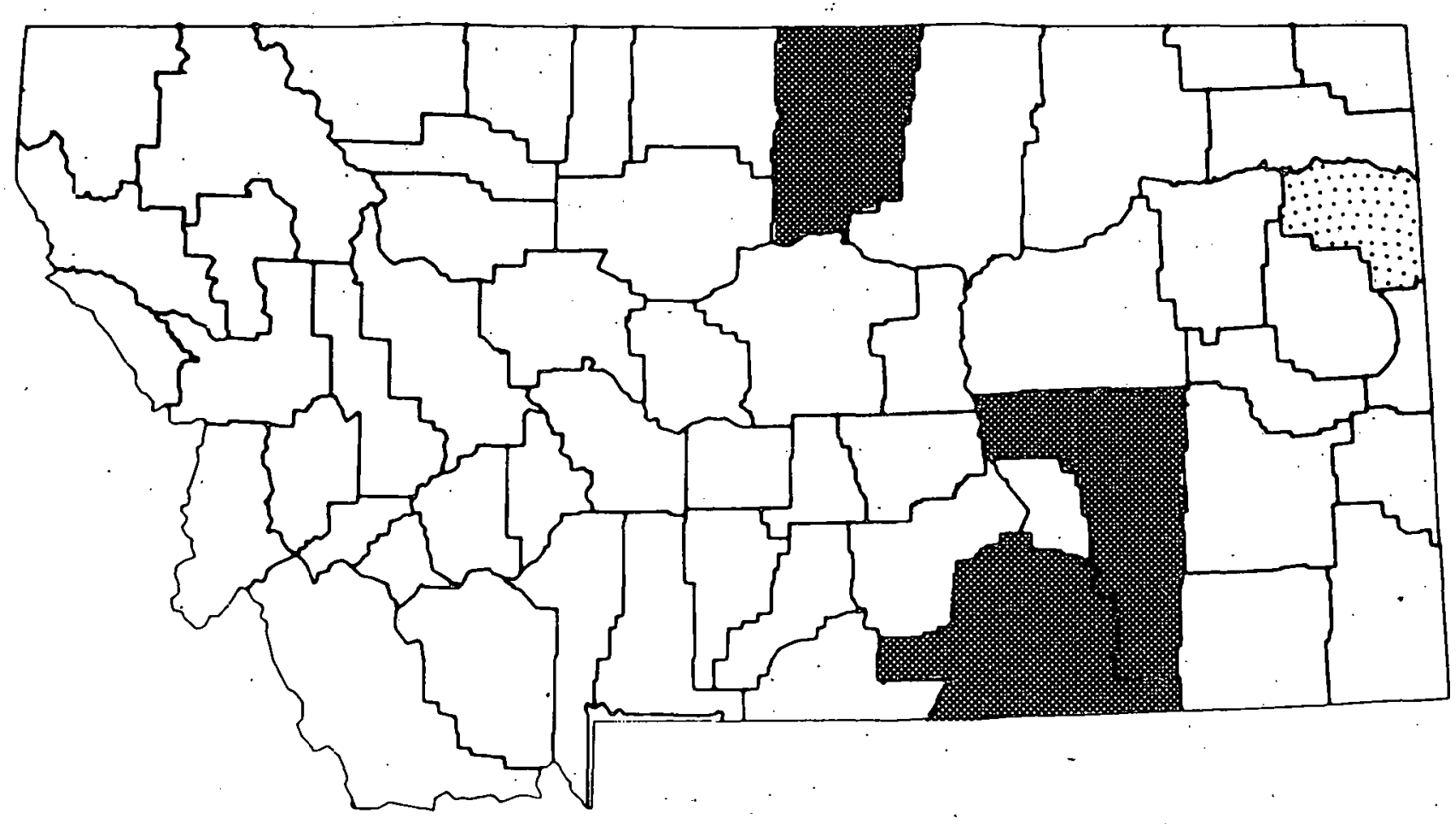

Fig. B.26 Montana: Coal Production in 1979 
Table B.27 New Mexico: Coal Quality Data

\begin{tabular}{|c|c|c|c|c|c|}
\hline $\begin{array}{l}\text { COUNTY } \\
\text { NAMES }\end{array}$ & $\begin{array}{l}\text { AVE. SO2 } \\
\text { CONTENT } \\
\text { (LBS/MBTU) }\end{array}$ & $\begin{array}{l}\text { CVE ASH } \\
\text { CONTENT } \\
\text { (PERCEAT) }\end{array}$ & $\begin{array}{l}\text { AVE. HEAT } \\
\text { VALUE } \\
\text { (BTU/LE) }\end{array}$ & $\begin{array}{l}\text { WASHAB } \\
\text { PEPCEAT S } \\
\text { REMCVAL }\end{array}$ & $\begin{array}{l}\text { ITY DATA } \\
\text { BTU LOSS } \\
\text { (OERCENT) }\end{array}$ \\
\hline $\begin{array}{l}\text { CCLFAX } \\
\text { MCKINLEY } \\
\text { SAN IUAN }\end{array}$ & $\begin{array}{r}.79 \\
: 98 \\
1.62\end{array}$ & $\begin{array}{l}14.49 \\
13.74 \\
21.15\end{array}$ & $\begin{array}{r}12058 \\
9870 \\
8905 .\end{array}$ & $\begin{array}{r}8.55 \\
17 \cdot 39 \\
21.96\end{array}$ & $\begin{array}{l}2.21 \\
5 \cdot 05 \\
5: 71\end{array}$ \\
\hline
\end{tabular}


lb $\mathrm{SO}_{2} / 10^{6} \mathrm{Btu} \square 0-1.2 \square 1.2-3.2$

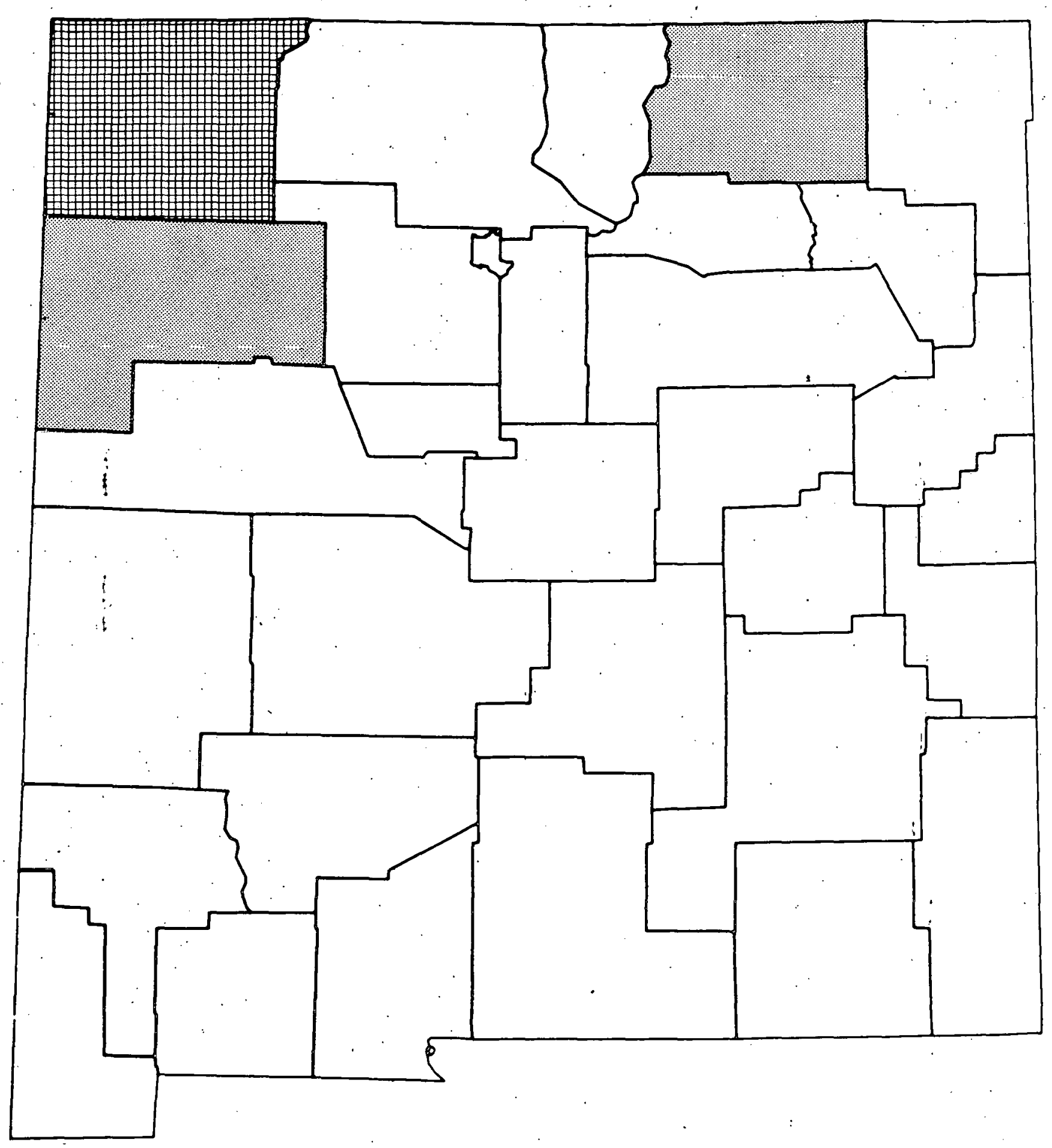

Fig. B.27 New Mexico: Average Sulfur Content of Coal 
Table B.28 New Mexico: Coal Production and Reserves Tonnage

COUNTY
NAME
CCLFAX
LINCOLN
MCKINLEY
RIC ARRIBA
SANDOVAL
SAN JUAN
SANTA FE
SCCORFO
VALENCIA

TCTAL.
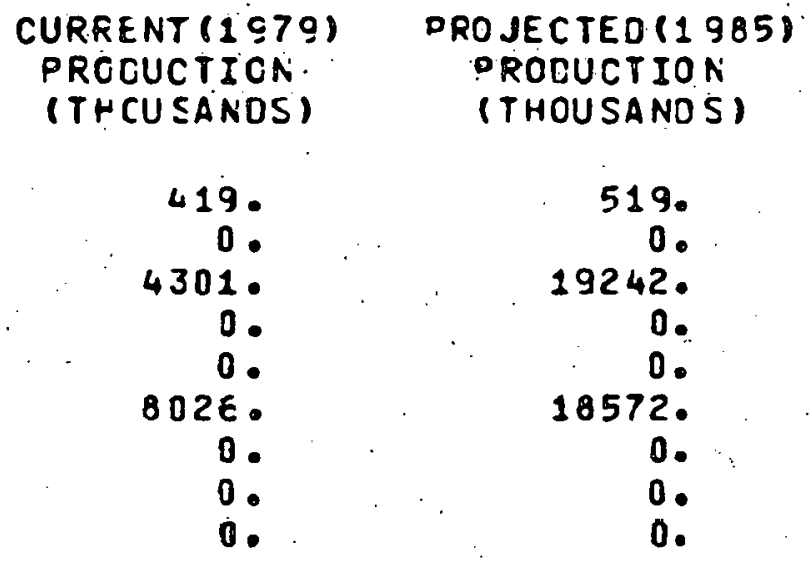

PESEFVES

(MILLIONS)

1381. 7. 363. 7. 52. 2545 11. 28. 0. 
$10^{3}$ Tons $0-500>1000$

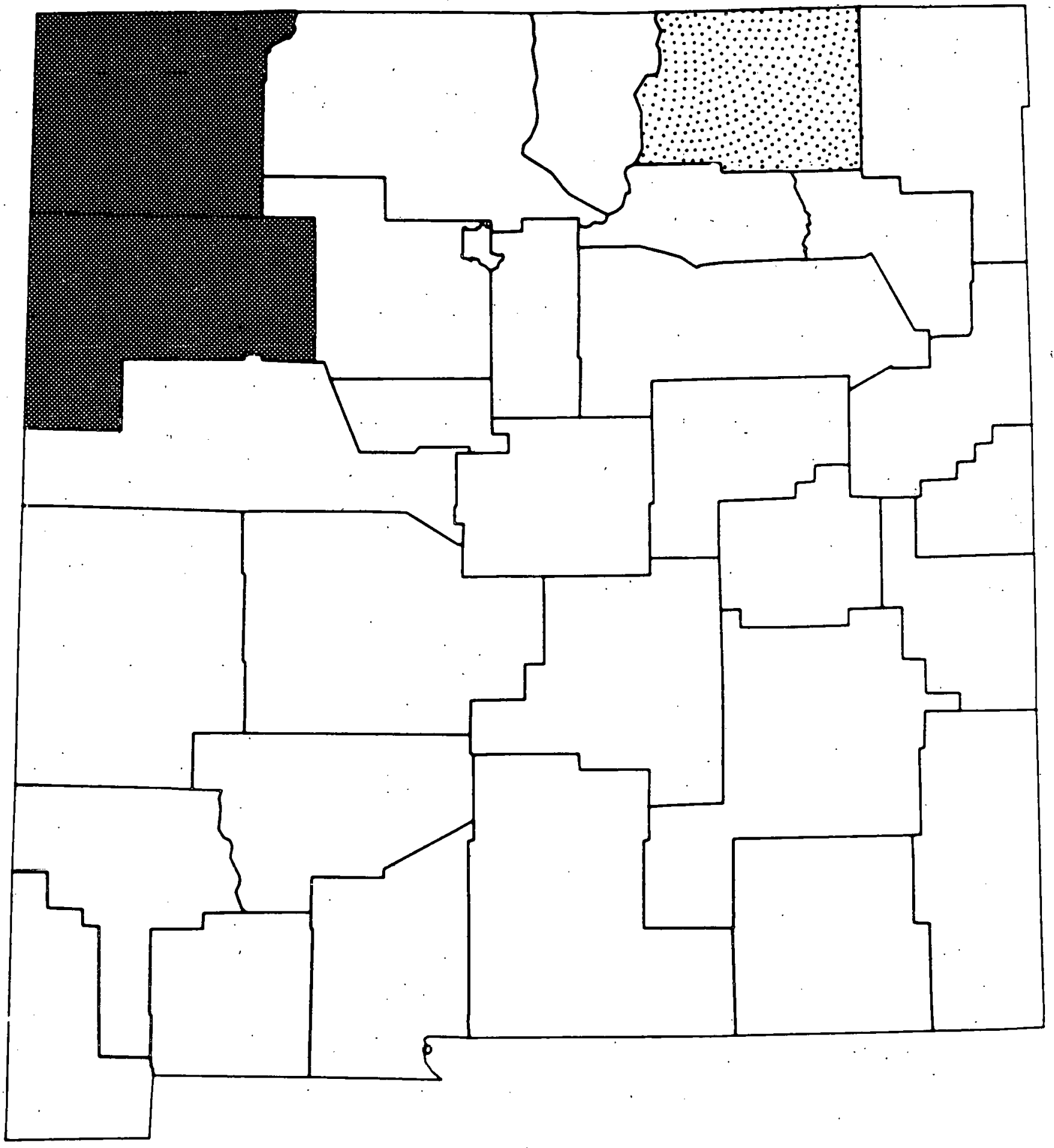

Fig. B.28 New Mexico: Coal Production in 1979 
Table B.29 North Dakota: Coal Quality Data

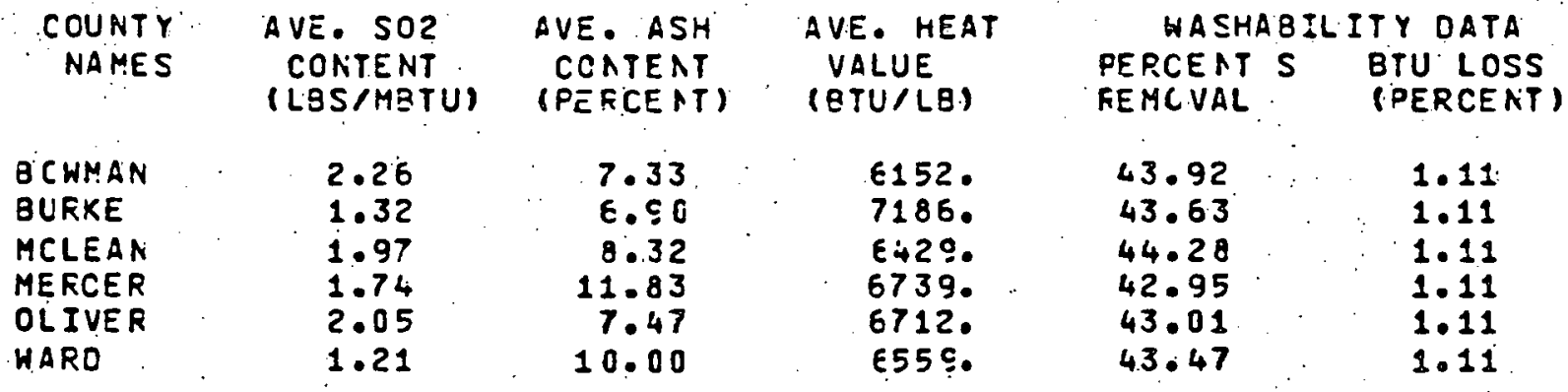


$\therefore \quad \therefore \quad \because \because \mathrm{lb}: \mathrm{SO}_{2} / 1 \mathrm{O}^{6} \mathrm{Btu}$

$1.2-3.2$

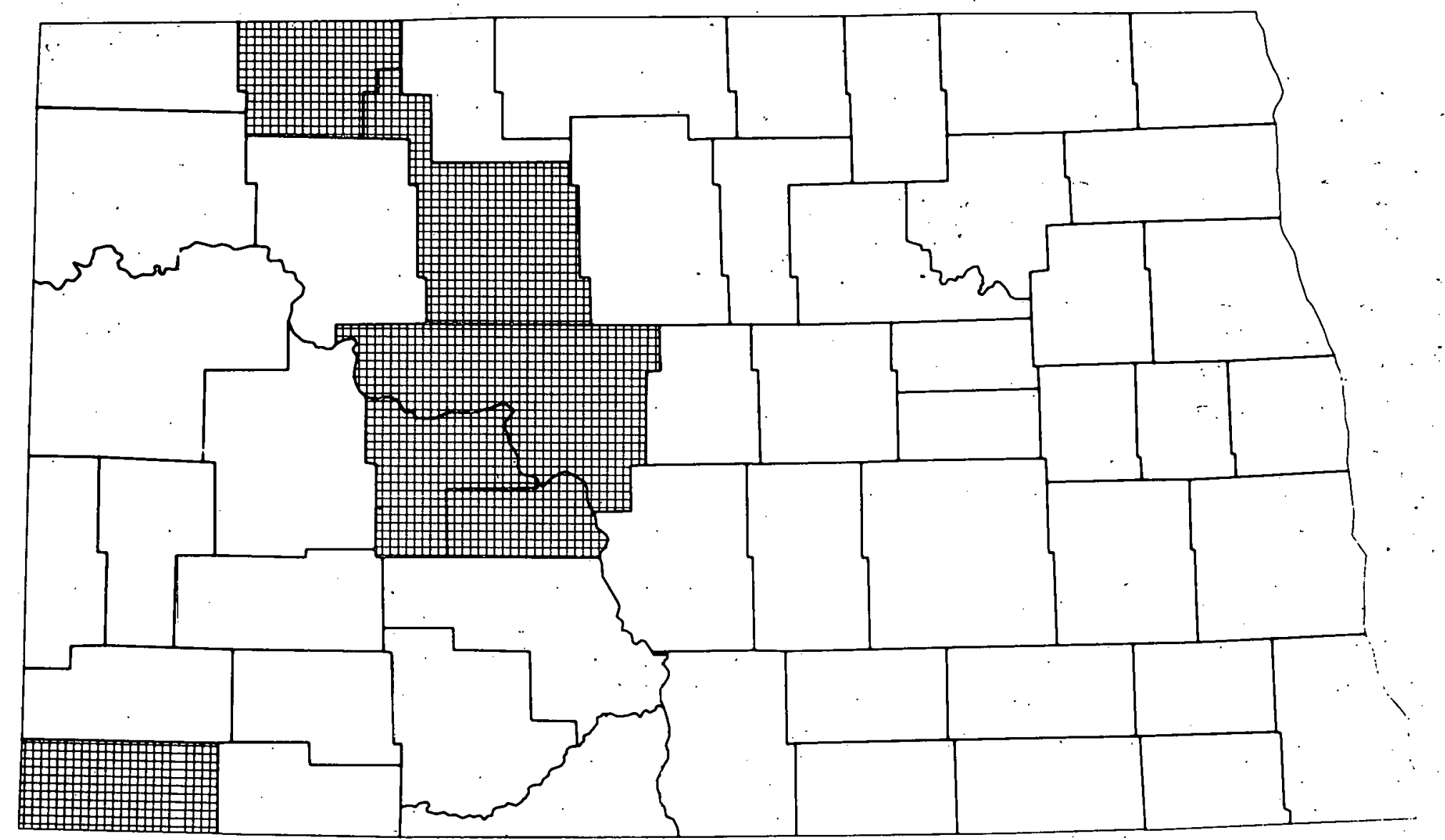

Fig. B.29 North Dakota: Average Sulfur Content of Coal 
Table B.30. North Dakota: Coal Production and Reserves Tonnage

\section{COUNTY \\ NAME}

ACAMS

BILLINGS

BCWMAN

BURKE

BURLE IGH

DIVIDE

DUNN.

GCLDEA VAL

GFANT

HETT INGER

MCHENFY

MCKENZIE

MCLEAN

MERCE R

MCET ON

MCUNT FAIL

OLIVEF

RENVILLE

SLOPE

STARK

WAPD

WILLIAMS

VARIOUS*

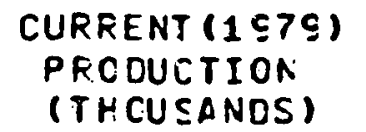

PRCDUCTION
(THCUSANOS)

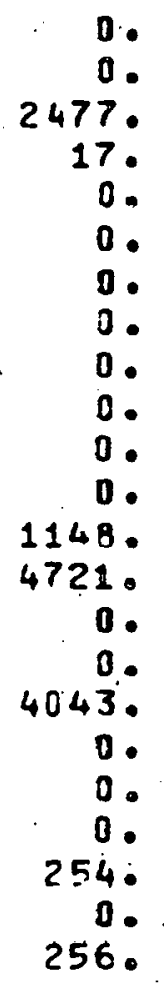

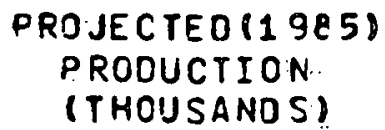

PRODUCTION.
(THOUSANOS)

RESERVES

(MILLIONS)

AL

TOTAL

12915.

43842 .

15999.

* this f fgure represents data not assigned to a specific ccunty. 


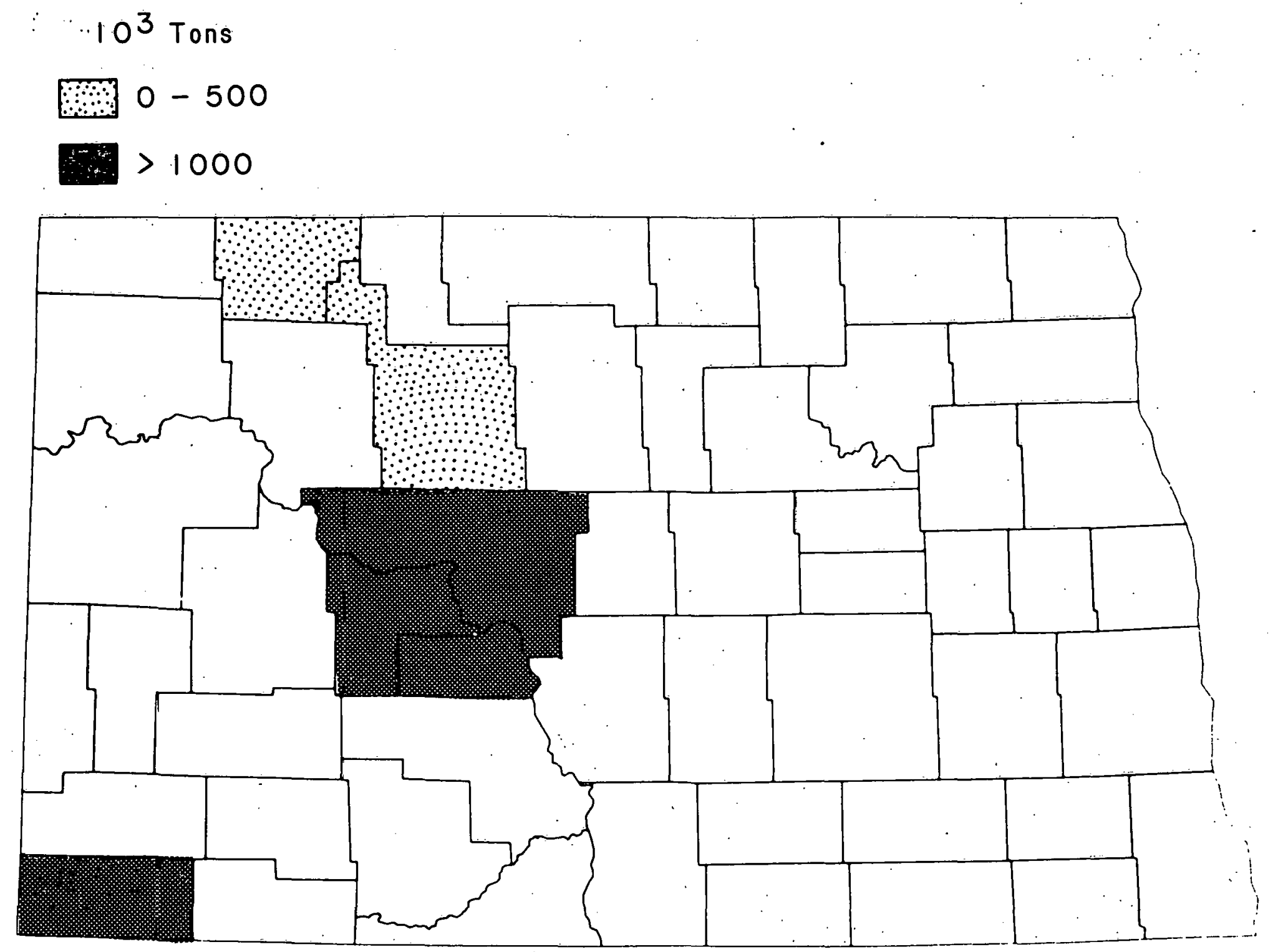

Fig. B.30 North Dakota: Coal Production in 1979 
Table.B.31 Ohio: Coal Quality Data

$\begin{array}{cccc}\text { COUNTY AVE. SO2 } & \text { AVE. ASH } & \text { AVE. HEAT } \\ \text { NAMES } & \text { CONTENT } & \text { COATENT } & \text { VALUE } \\ \text { (LBS/MBTUI } & \text { (PERCENT) } & \text { (BTU/LG) }\end{array}$

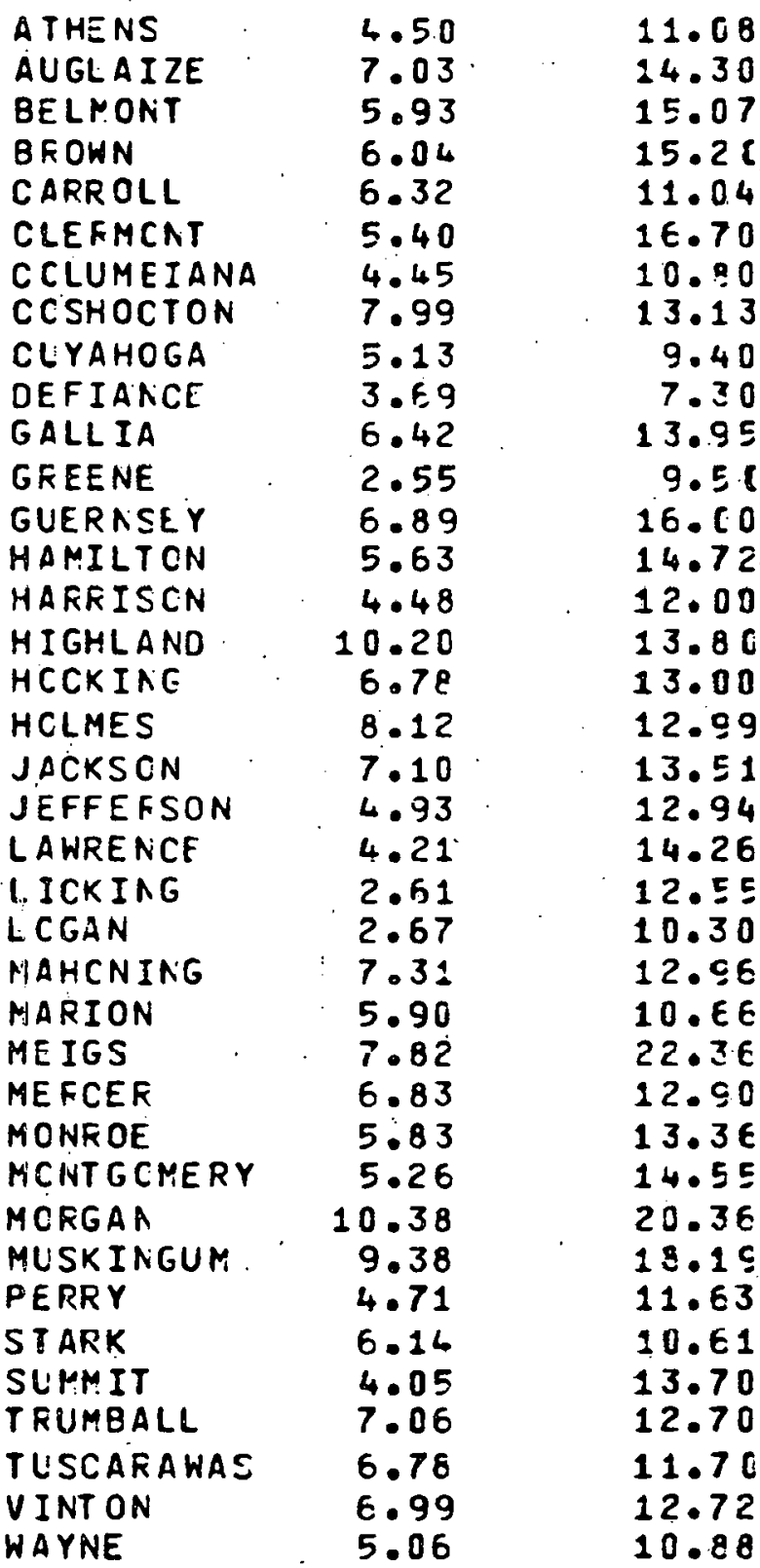

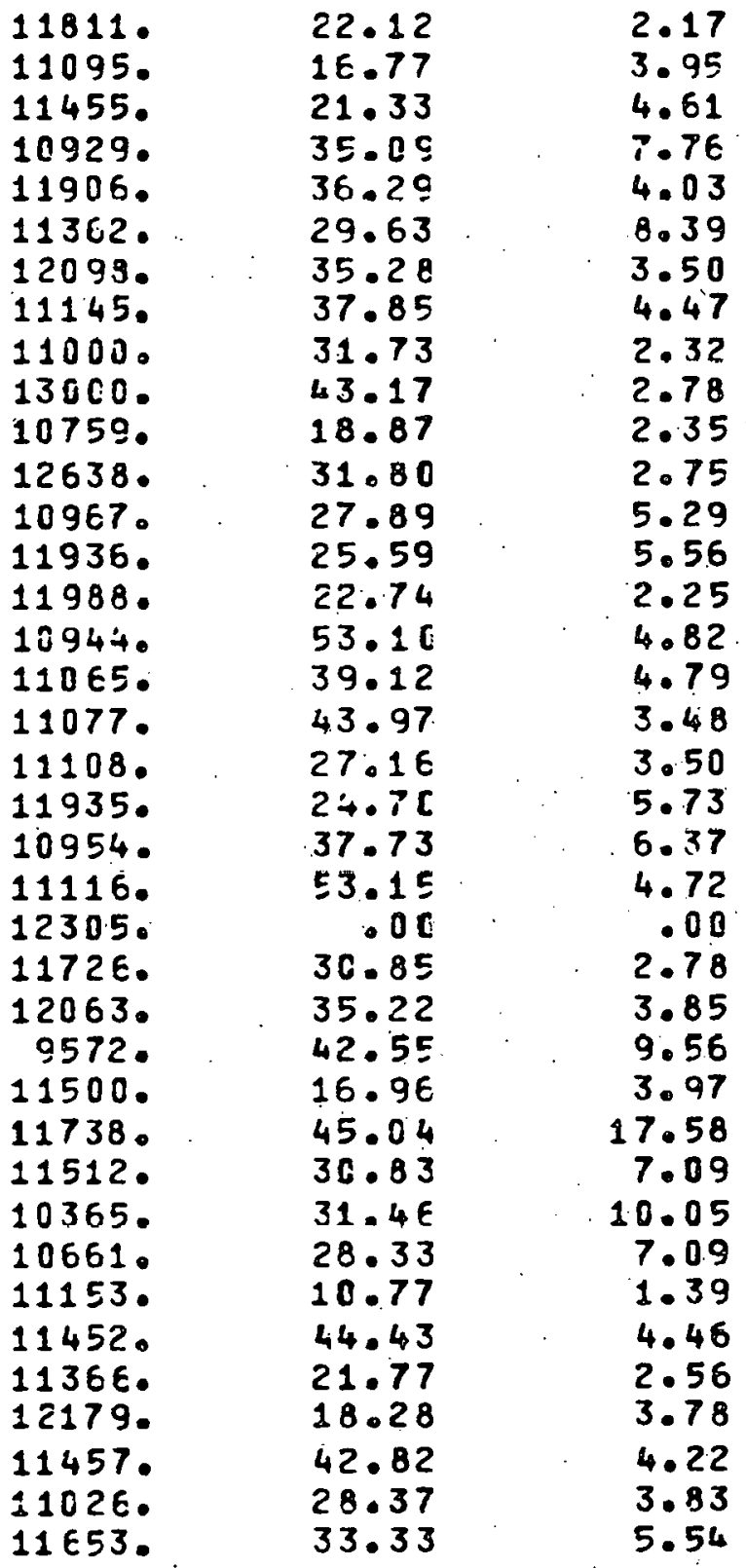

WASHABILITY DATA PERCENT S BTU LOSS REMCVAL (PERCENT) 
Ib $\mathrm{SO}_{2} / 10^{6} \mathrm{Btu}$

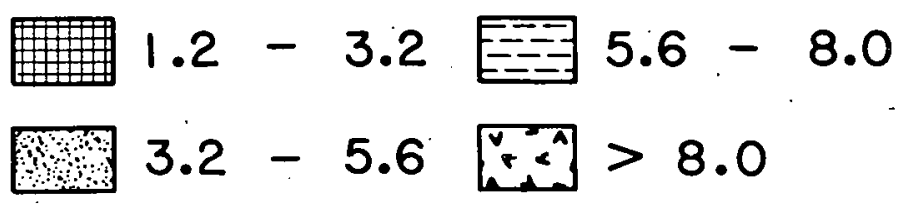

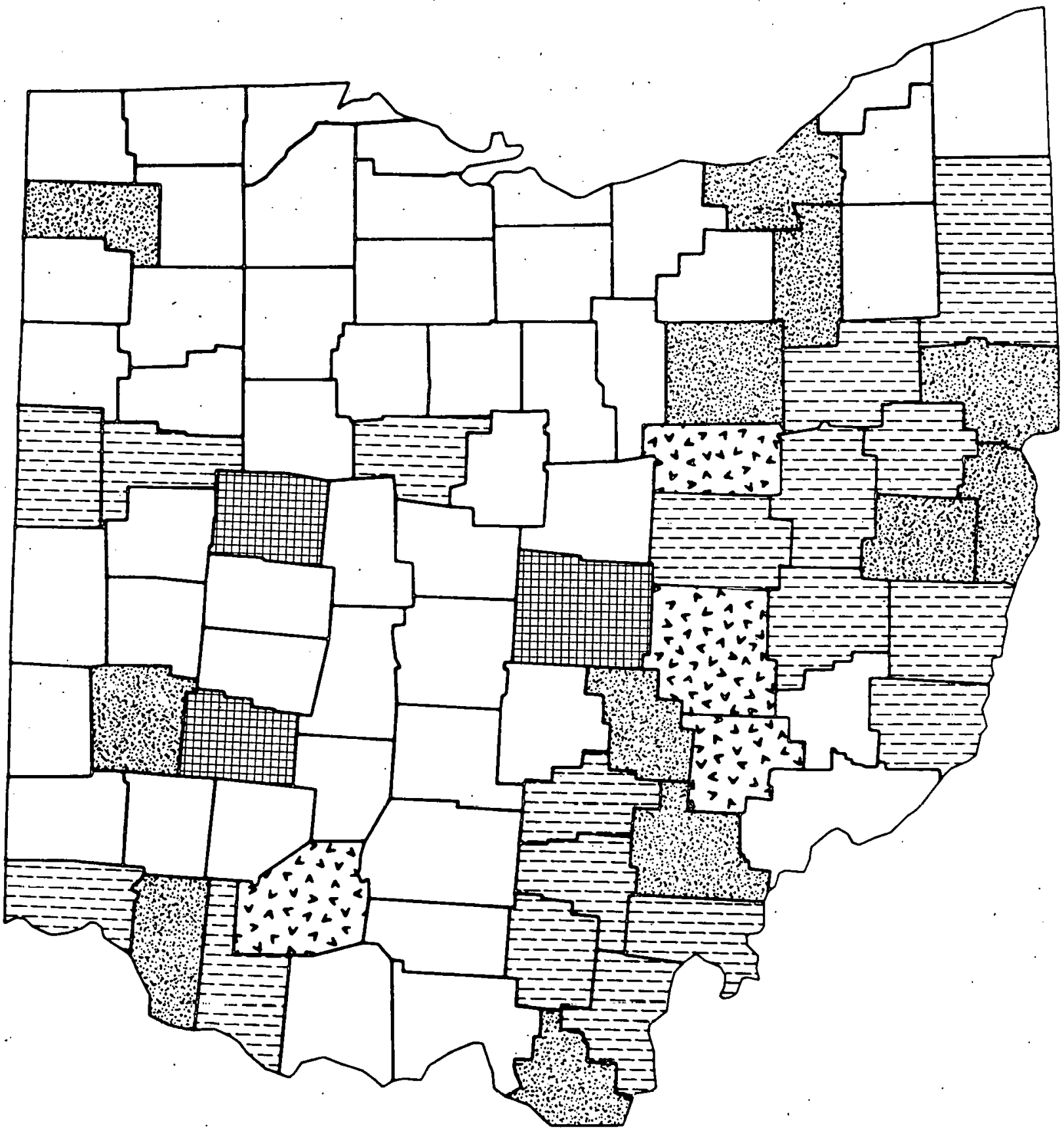

Fig. B.31 Ohio: Average Sulfur Content of Coal 
Table B. 32 Ohio: Coal Production and Reserves Tonnage

\section{COUNTY \\ NAME}

A THENS

AUGLAIZE

BELMONT

BROWN

CARFOLL

CCLUMEIANA

CCSHOCTON

CLYAHOGA

DEFIANCE

GALLIA

GREENE

GLERNSEY

HARRISCN

HIGHLAND

HCCKING

HCLMES

JACKSON

JEFFEFSON

LAWRENCE

L ICKING

LCGAN

MAIICNING

MAFION

MEIGS

ME RCER

MCNROE

MCNTGCRERY

MCRGAA

MLSKINGUM

NCBLE

PERRY

SC IOTO

STARK

TUSCARAWAS

VINTON

WASHIAGTCN

WAYNE

VARIOUS*

\section{CUREENT (1975) \\ PRCOUCTION \\ (THCUSAHOS)}

\section{PFOJECTED (1985) \\ PRODUCTION \\ (THOUSANDS)}

FESERVES

( $N$ ILL IONS)

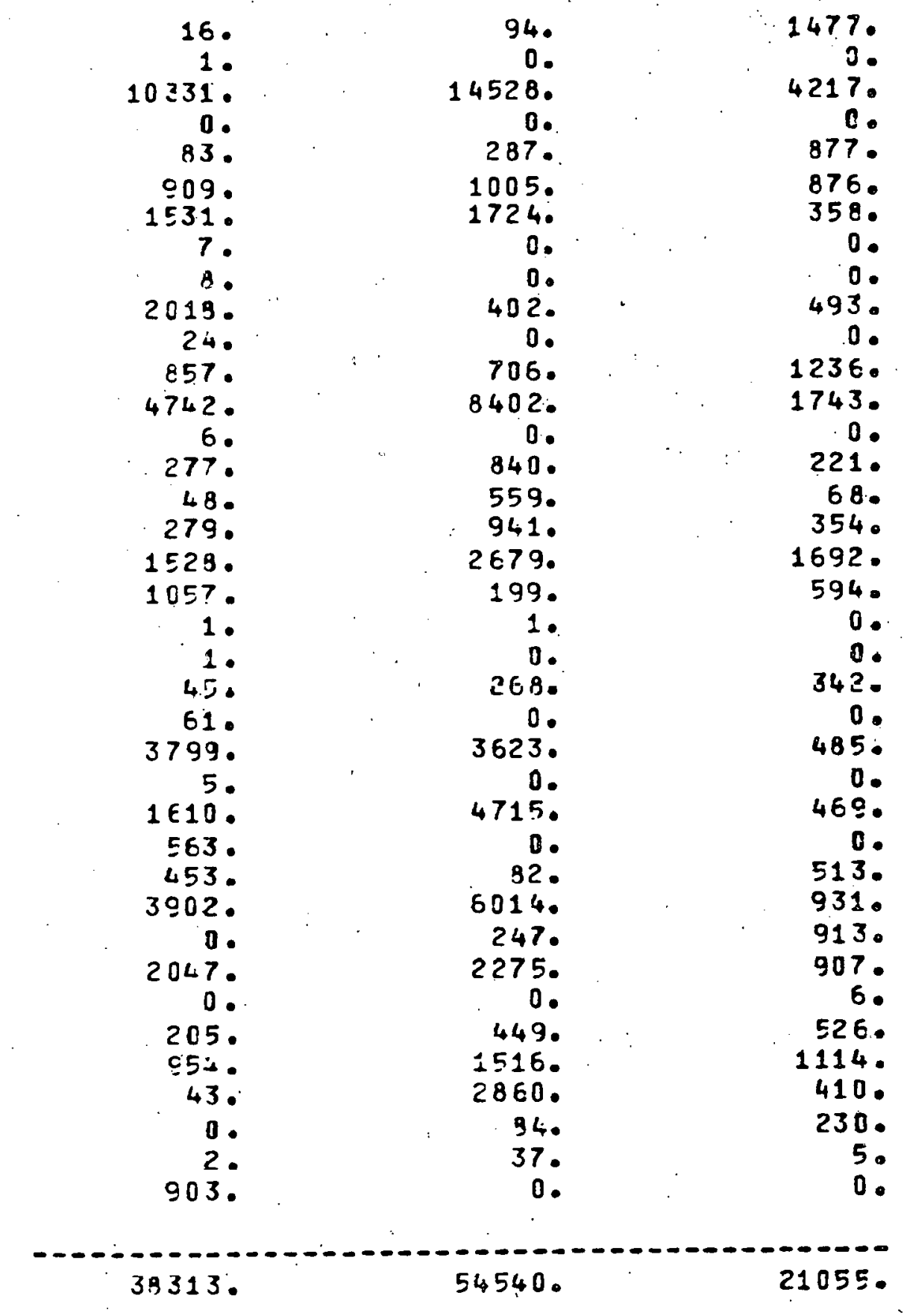

TOTAL

* this figure represeats data not assigned to a sfecific county. 


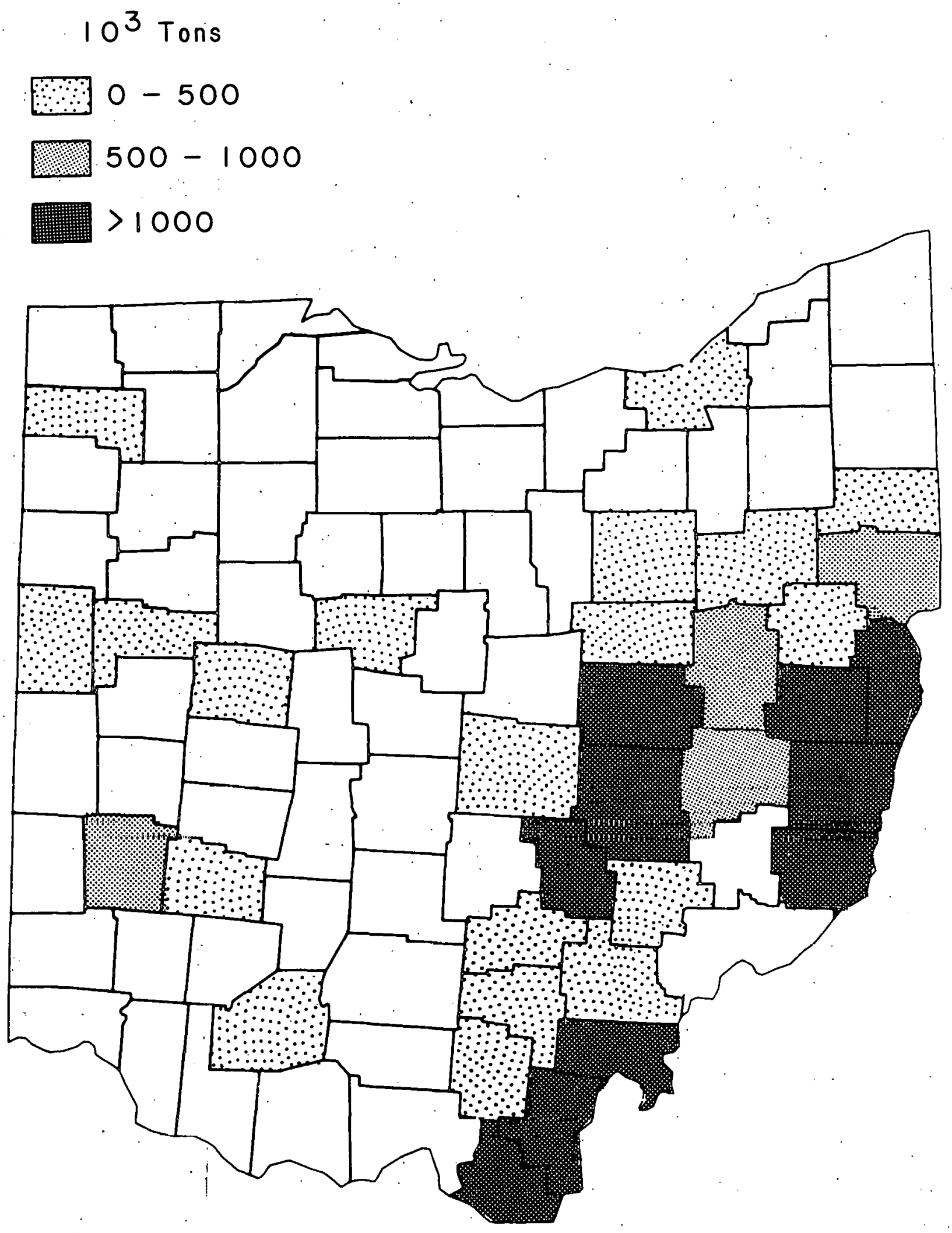

Fig. B.32 Ohio: Coal Production in 1979 
Table B.33 Oklahoma: Coal Quality Data

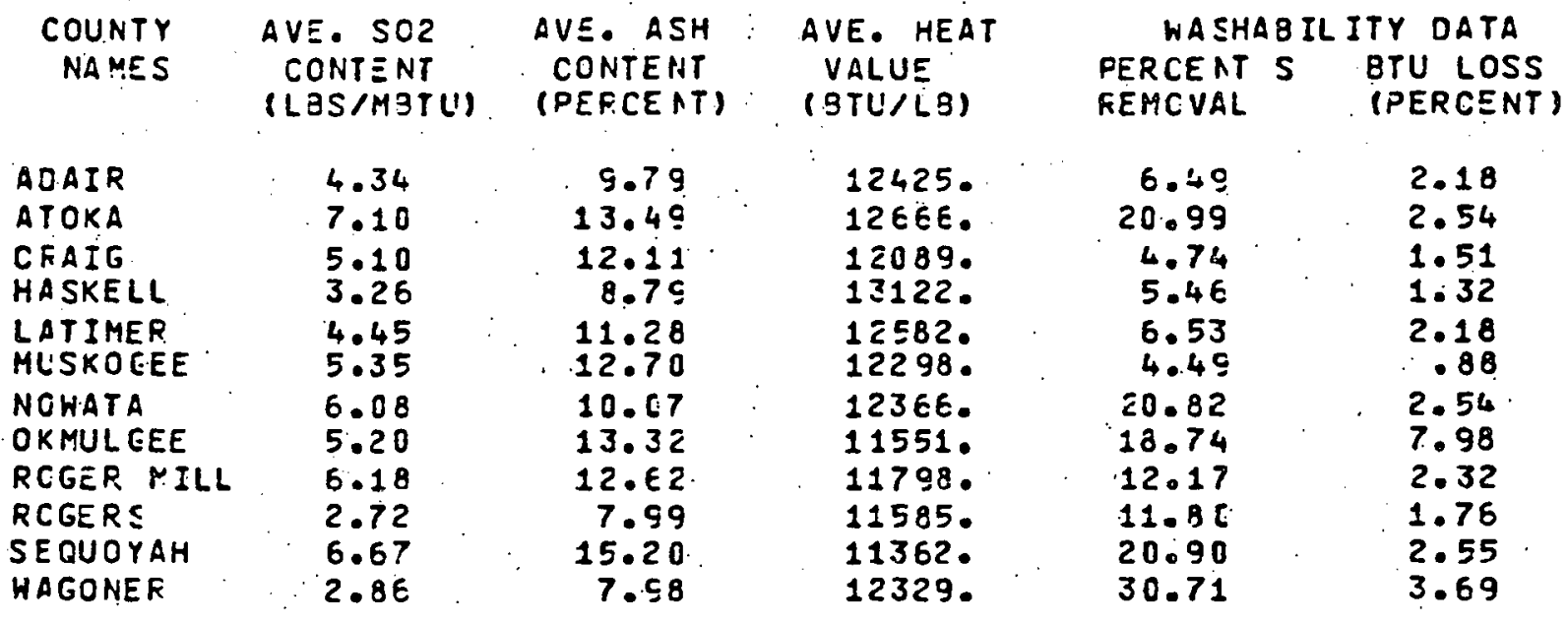




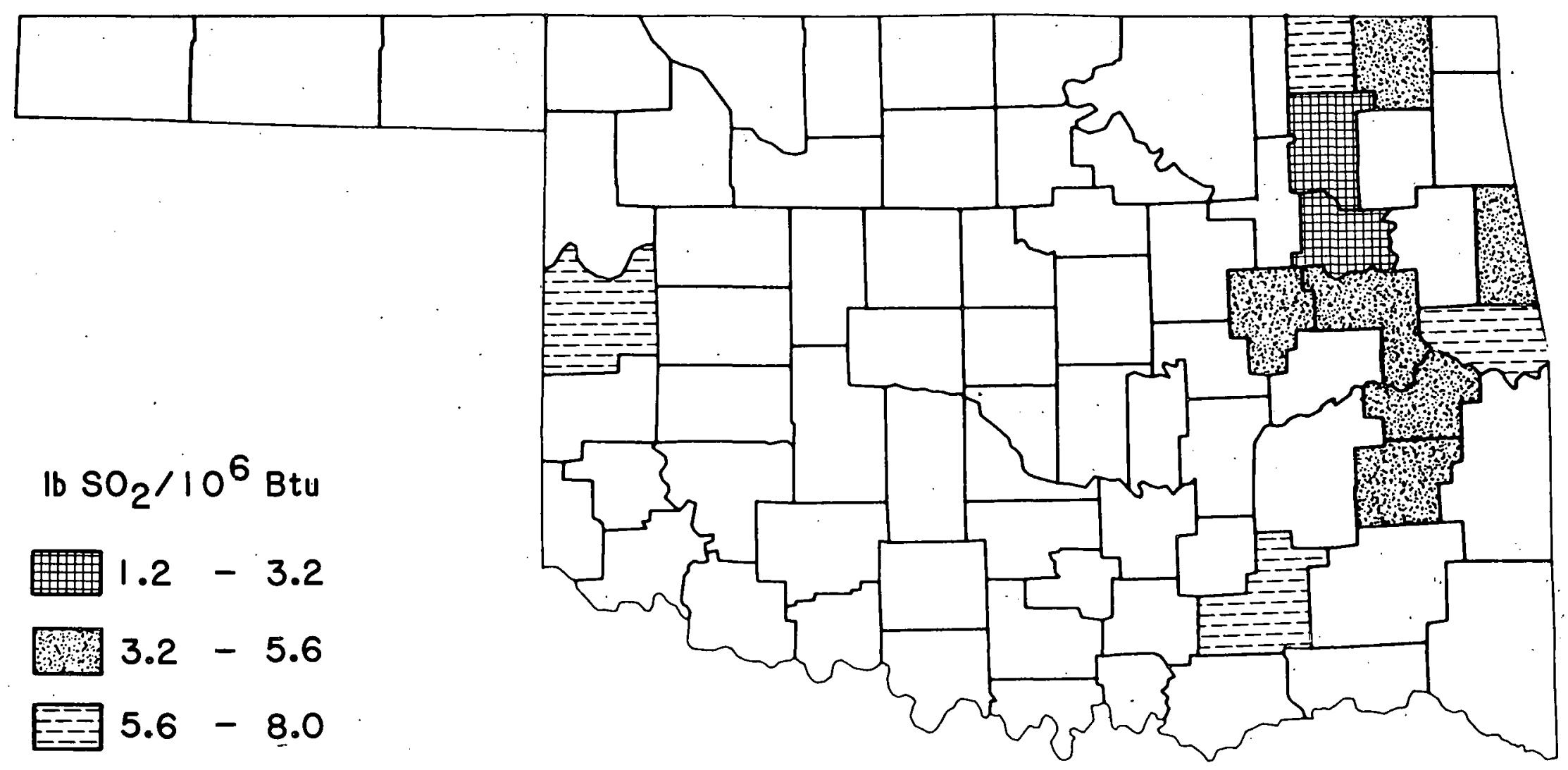

Fig. B.33 Oklahoma: Average Sulfur Content of Coal 
Table B.34 Oklahoma: Coal Production and Reserves Tonnage

\begin{tabular}{|c|c|c|c|}
\hline $\begin{array}{l}\text { COUNTY } \\
\text { NAME }\end{array}$ & $\begin{array}{l}\text { CURRENT (1979) } \\
\text { PROOUCTICA } \\
\text { (THCUSANOS) }\end{array}$ & $\begin{array}{l}\text { FROJECTED (1985) } \\
\text { PRODUCTION } \\
\text { (THOUSANOS) }\end{array}$ & $\begin{array}{l}\text { RESERVES } \\
\text { (MILLIONS) }\end{array}$ \\
\hline $\begin{array}{l}\text { ACAIR } \\
\text { ATOKA }\end{array}$ & 25. & $\begin{array}{l}0.0 \\
0 .\end{array}$ & $\begin{array}{l}0 . \\
150^{\circ}\end{array}$ \\
\hline $\begin{array}{l}\text { CCAL } \\
C F A I G \\
\text { HASKELL } \\
\text { LATIMER }\end{array}$ & $\begin{array}{r}0 . \\
518 . \\
209 . \\
49 .\end{array}$ & $\begin{array}{r}0 . \\
24540^{\circ} \\
6000 \\
13 .\end{array}$ & $\begin{array}{l}56 . \\
238 \\
140 \\
84 .\end{array}$ \\
\hline $\begin{array}{l}\text { LEFL OFE } \\
\text { MCIATCSH }\end{array}$ & 0. & 140. & $\begin{array}{r}31 \epsilon_{0} \\
6 .\end{array}$ \\
\hline $\begin{array}{l}\text { MUSKOGEE } \\
\text { NCWATA }\end{array}$ & $\begin{array}{l}72 . \\
49 .\end{array}$ & $\begin{array}{r}172 . \\
. \quad 54 .\end{array}$ & $\begin{array}{r}3 . \\
78 .\end{array}$ \\
\hline $\begin{array}{l}\text { OKFUSKEE } \\
\text { OKMUL EEE }\end{array}$ & $\begin{array}{r}0 . \\
50 .\end{array}$ & $\begin{array}{l}0 . \\
481 .\end{array}$ & 124 \\
\hline $\begin{array}{l}\text { PITTSEURG } \\
\text { RCGER MILLL }\end{array}$ & $1024^{0}$ & 40. & $\begin{array}{r}15 E \\
0\end{array}$ \\
\hline $\begin{array}{l}\text { ROGERS } \\
\text { SE QUOYAH } \\
\text { TLLSA: }\end{array}$ & $\begin{array}{l}2 . \\
5 . \\
0 .\end{array}$ & $\begin{array}{r}250 . \\
0 . \\
0 .\end{array}$ & $\begin{array}{l}50 . \\
9 . \\
9 .\end{array}$ \\
\hline $\begin{array}{l}\text { WAGONER } \\
\text { VARIOUS* }\end{array}$ & $\begin{array}{l}232 . \\
540 .\end{array}$ & $\begin{array}{r}260 . \\
0 .\end{array}$ & $\begin{array}{l}4 . \\
0\end{array}$ \\
\hline & & & \\
\hline TETAL & 2775. & $44 \sigma \varepsilon$. & 1230. \\
\hline
\end{tabular}

* this figlire represents data not assigned to a sfecific cCunty. 


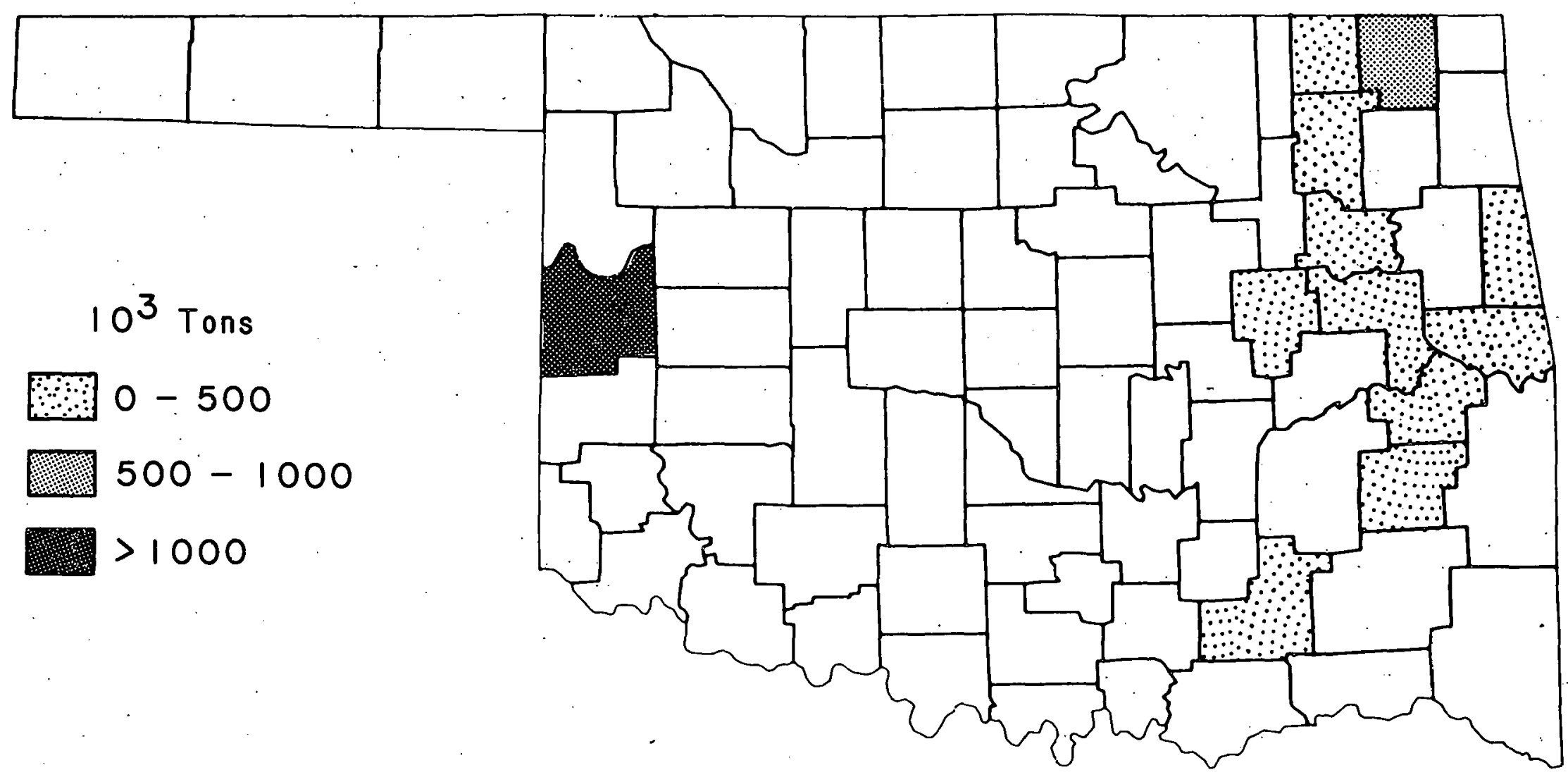

Fig. B.34 Oklahoma: Coal Production in 1979 
Table B.35 Pennsylvania: Coal Quality Data

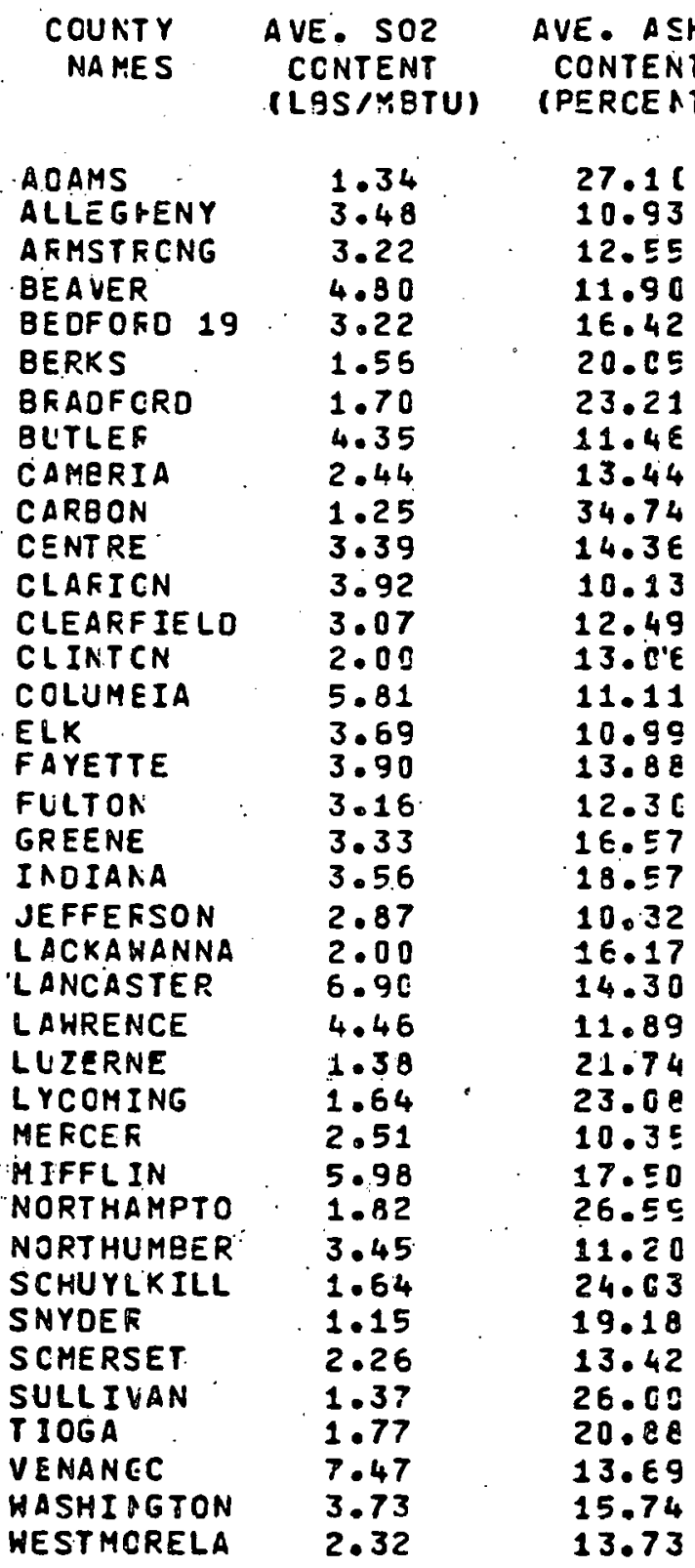

\author{
AVE. HEAT \\ VALUE \\ (BTU/LE)
}

10178 .

12459.

12282 .

11836.

$11934^{\circ}$

10131.

10869

12115.

12463.

7206 .

12378 .

12605.

12445.

12364 。

12566.

$1<592$.

11097.

12244.

11562 .

11858 .

12683.

10928 .

11282 .

11977.

90.11 .

10904.

12197.

10995.

86 ค2.

12750 .

9541.

10427.

11977 .

10186.

11180 .

$11933^{\circ}$.

11842 .

12122.
WASHABILITY DATA

PERCEAT S BTU LOSS
REMOVAL

$\begin{array}{rr}54.66 & 12.90 \\ 14.97 & 1.99 \\ 31.85 & 5.86 \\ 35.61 & 3.20 \\ 52.66 & 6.40 \\ 22.53 & 7.01 \\ 38.77 & 12.90 \\ 24.34 & 7.03 \\ 9.93 & 1.56 \\ 59.54 & 15.48 \\ 23.79 & 4.76 \\ 21.59 & 1.31 \\ 33.44 & 3.94 \\ 3.10 & .56 \\ 36.44 & 4.81 \\ 27.42 & 3.76 \\ 20.20 & 8.87 \\ 27.36 & 3.51 \\ 9.53 & 3.05 \\ 28.09 & 5.01 \\ 18.54 & 2.35 \\ 14.56 & 4.71 \\ 38.80 & 6.13 \\ 31.96 & 4.46 \\ 26.62 & 8.48 \\ 35.70 & 11.16 \\ 13.29 & 1.73 \\ 8.77 & 3.77 \\ 49.93 & 12.91 \\ 14.76 & 3.03 \\ 41.74 & 10.33 \\ 31.81 & 9.69 \\ 23.67 & 3.80 \\ 21.04 & 9.00 \\ 55.51 & 12.05 \\ 53.77 & 2.76 \\ 14.69 & 5.72 \\ 22.19 & \\ & \end{array}$




\section{Ib $\mathrm{SO}_{2} / 10^{6} \mathrm{Btu}$}
$\square 0-1.2 \square 3.2-5.6$
$1.2-3.2$ E E $5.6-8.0$

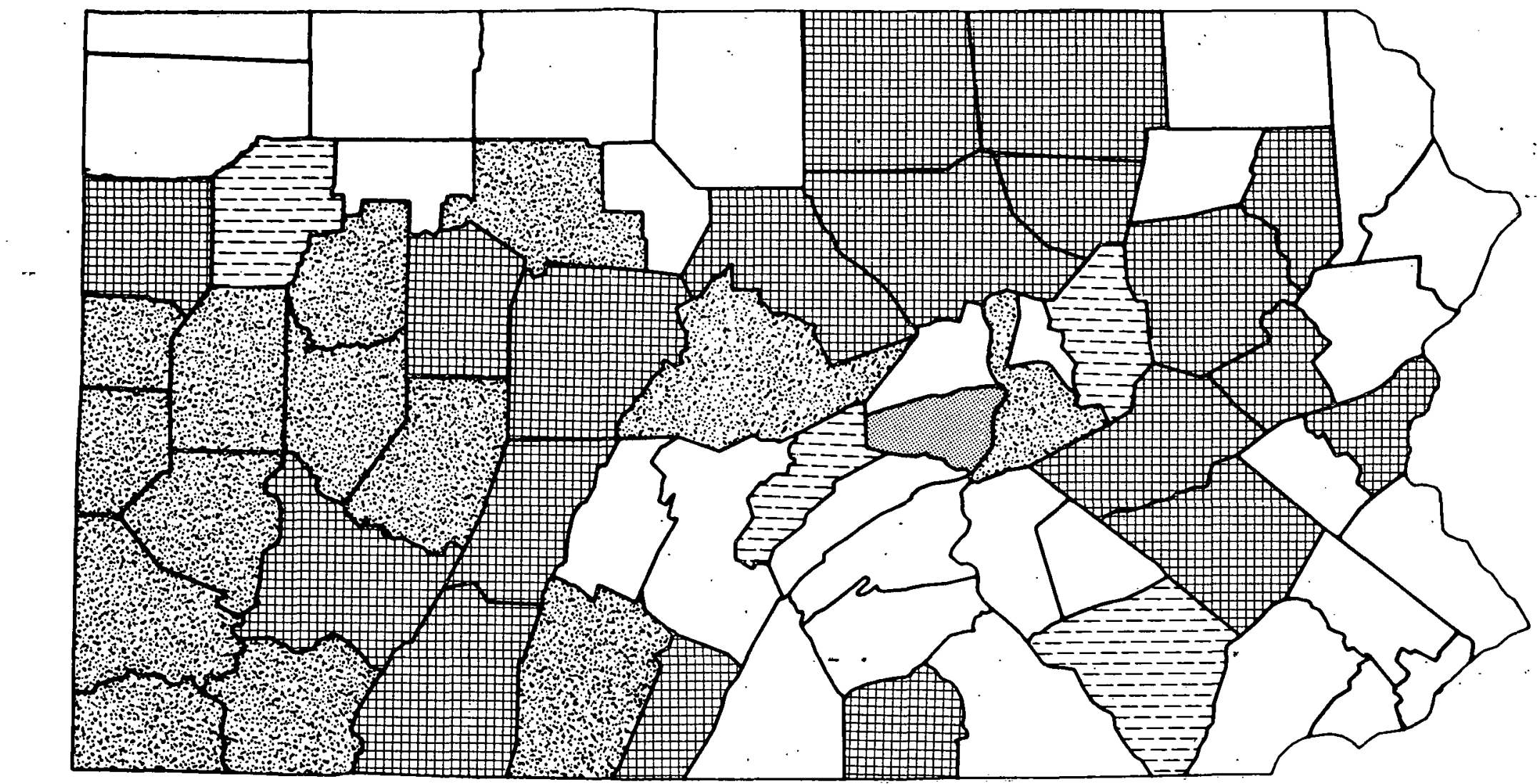

Fig. B.35 Pennsylvania: Average Sulfur Content of Coal 
Table B.36 Pennsylvania: Coal Production and Reserves Tonnage

COUNTY
NAME

AOAMS

ALLEG FENY

AFMSTRCNG

BEAVER

BEDFOFO 19

BERKS

BLAIR

BFADF CRO

BUTLEK

CAMERIA

CAMERCN

CARBON

CENTRE

CLAFICN

CLEARF IELO

CLINT CN

CCLUMEIA

ELK

FAYETTE

FLLTON

GREENE

HUNT INGDON

IADIANA

JEFFE FSON

LACKAWANNA

LANCASTER

L A HRENCE

LUZERNE.

LYCCMING

MCKEAA

MERCER

MIFFL IN

NCET HAMPTO

SCHUYLKILL

SNYOEK

SCMERSET

SULL IVAN

T IOG A

VENANCO

WASHIAGTON

WEST MCRELA

VARIOUS*

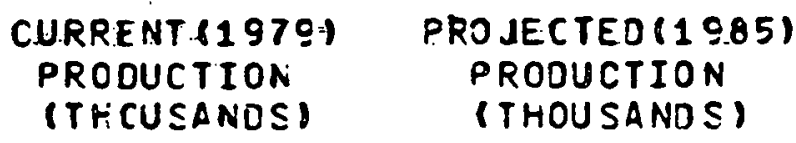

PRODUCTION
(THOUSANOS)

RESERVES

(R. ILL IONS)

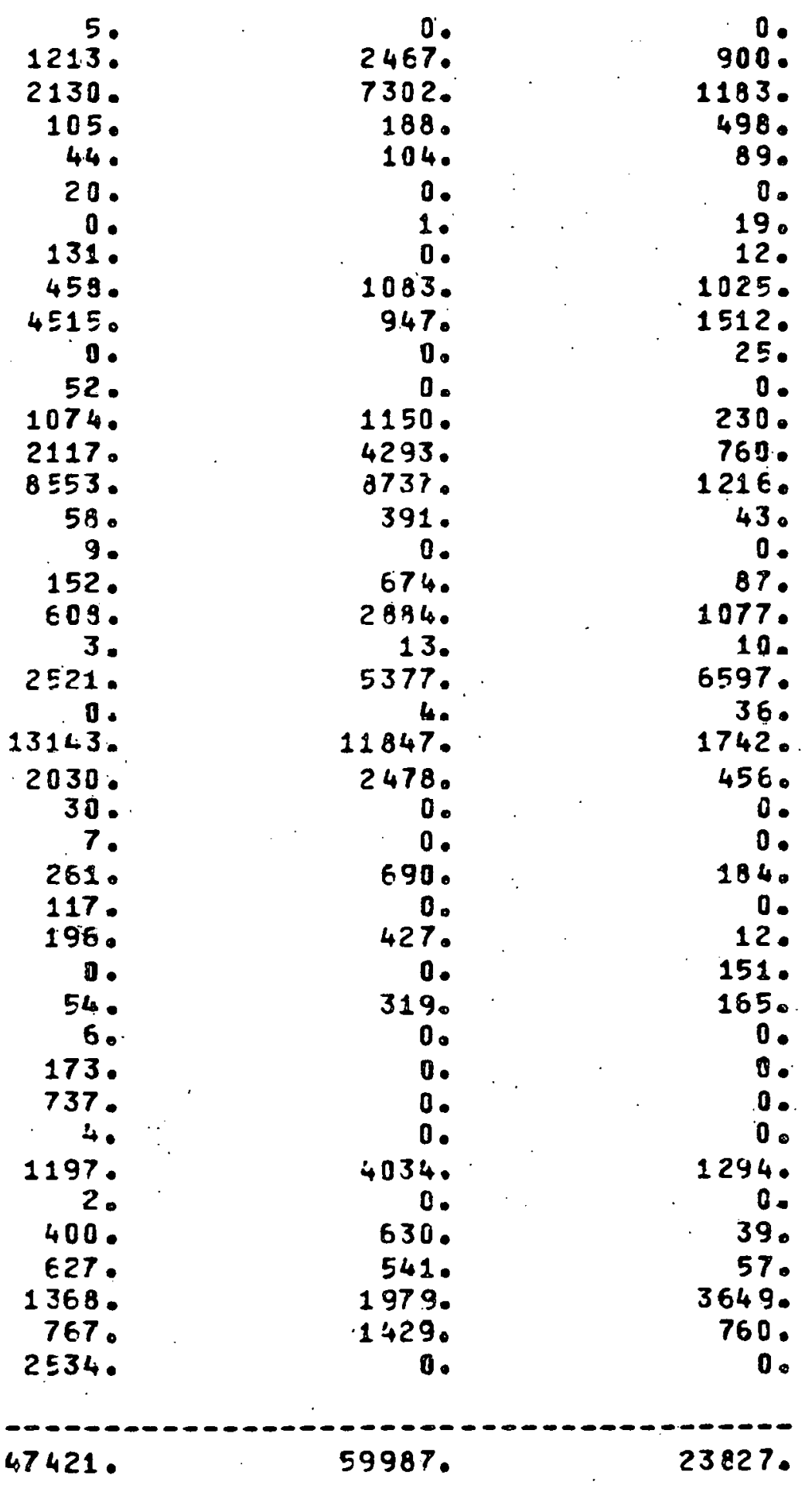

TOTAL

* thIS figuRE REPRESEATS DATA nOt ASSIGNED to a SFECIFic COUNTY. 
$10^{3}$ Tons

W $0-500$

500- 1000

$>1000$

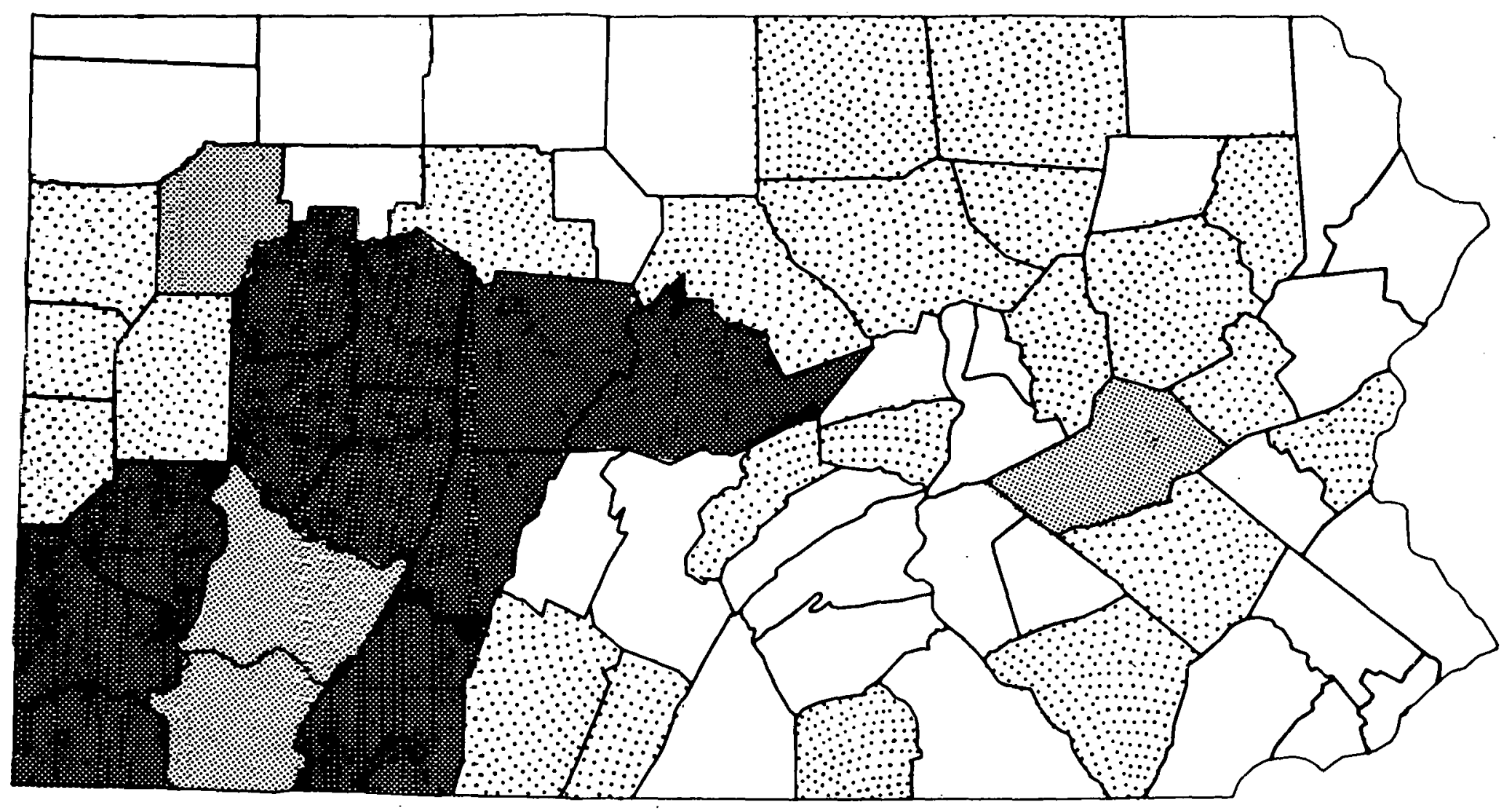

Fig. B.36 Pennsylvania: Coal Production in 1979 
Table B.37 Tennessee: Coal Quality Data

\begin{tabular}{|c|c|}
\hline $\begin{array}{l}\text { COUNTY } \\
\text { NAMES }\end{array}$ & $\begin{array}{l}\text { AVE } \\
\text { CONTE } \\
\text { CLBS/Y }\end{array}$ \\
\hline $\begin{array}{l}\text { ADERSCN } \\
\text { BENTON } \\
\text { BLEOSCE } \\
\text { SAMPBELL } \\
\text { SLAIBCRNE }\end{array}$ & \\
\hline $\begin{array}{l}\text { LMEERLAND } \\
\text { ENTRESS } \\
\text { RUNDY } \\
\text { AWKIAS } \\
\text { AFION } \\
\text { CFGAN } \\
\text { VERTON } \\
\text { HEA } \\
\text { CANE. } \\
\text { CEERTSON } \\
\text { COTT } \\
\text { EQUATCHIE } \\
\text { AN BUREN }\end{array}$ & 1. \\
\hline
\end{tabular}

AVE. ASH AVE. HEAT
COATENT MALUE
(PERCEAT) (BTU/LB)

$15.6 \mathrm{C}$

17.2 .0

12.95

12.30

$10 . E 3$

.12 .14

13.71

13.73

$12 . E 0$

13.79

13.05

17.10

16.03

11.14

14.70

12.42

13.21

11.43
11842.

11550 .

11941.

12081.

$12248^{\circ}$.

12281.

11820 .

12117.

12533.

12071:

12205.

11700 .

11880.

12554.

11753 .

12110 .

12458 .

12078 .

WASHABIL ITY DATA
PERCEAT S BTU LOSS
REMCVAL

23.63
28.66
17.92
17.58
6.51
9.38
16.77
9.38
.08
9.46
14.95
9.41
16.45
7.50
9.58
7.97
9.32
21.89

2.82

3.24

3.24

2.53

1.12

.87

2. 64

1.20

.00

1.30

2.38

1.21

3.44

- 90

1.20

.25

1.20

2.47 
Ib $\mathrm{SO}_{2} / 10^{6} \mathrm{Btu}$

$1.2-3.2$
$3.2-5.6$

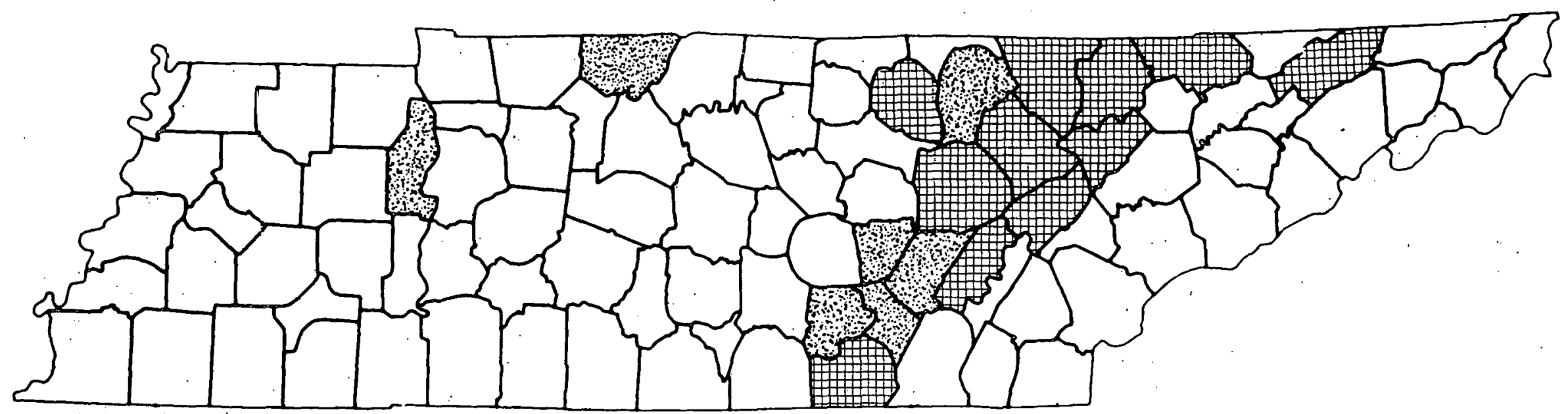

Fig. B.37 Tennessee: Average Sulfur Content in Coal 
Table B.38 Tennessee: Coal Production and Reserves Tonnage

$\begin{array}{lcc}\text { COUNTY } & \text { CURFENT (1979) } & \text { PROJECTEO(1985) } \\ \text { NAME } & \text { PRODUCTION } & \text { PROCUCTION } \\ & \text { (THCUSANDS) } & \text { (THOUSANDS) }\end{array}$

A A OERSON

BENT ON

BLEDSCE

CAMPBE LL

CLAIBCRNE

CUMBERLAND

FENTRESS

GRUNDY

HAMILTON

MAEION

MCFGAN

OVEFTON

PICKETT

PUTAAF

RHEA

RCANE

RCBERTSON

SCOTT

SE OUAT C.H IE

VAN BUREN

WFITE

VARIOUS*

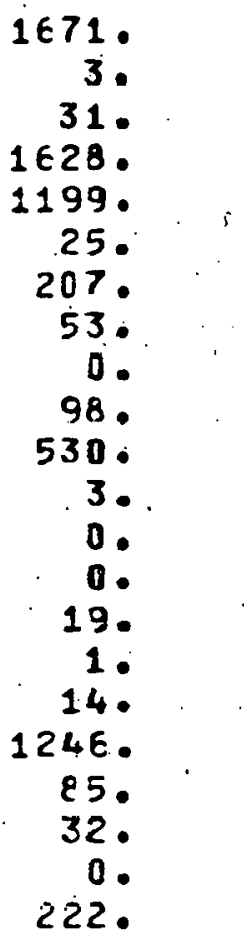

1670.

148.

1620 .

1201.

114.

492 .

53.

0.

538.

632 .

33.

0 .

94.

0.

67.

0.

1275.

791.

108 .

0.

0.

RESERVES

(MILL IONS)

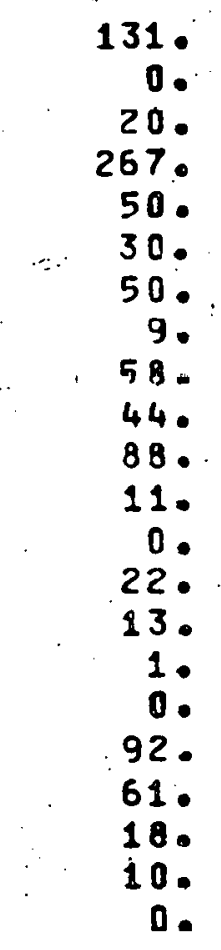

TCTAL

$7 C \in 8$.

8835 .

976.

* this figure represents data nOt assigred to a sfecific cCUATY. 
$10^{3}$ Tons

$\because 0-500$

? $500-1000$

> $>1000$

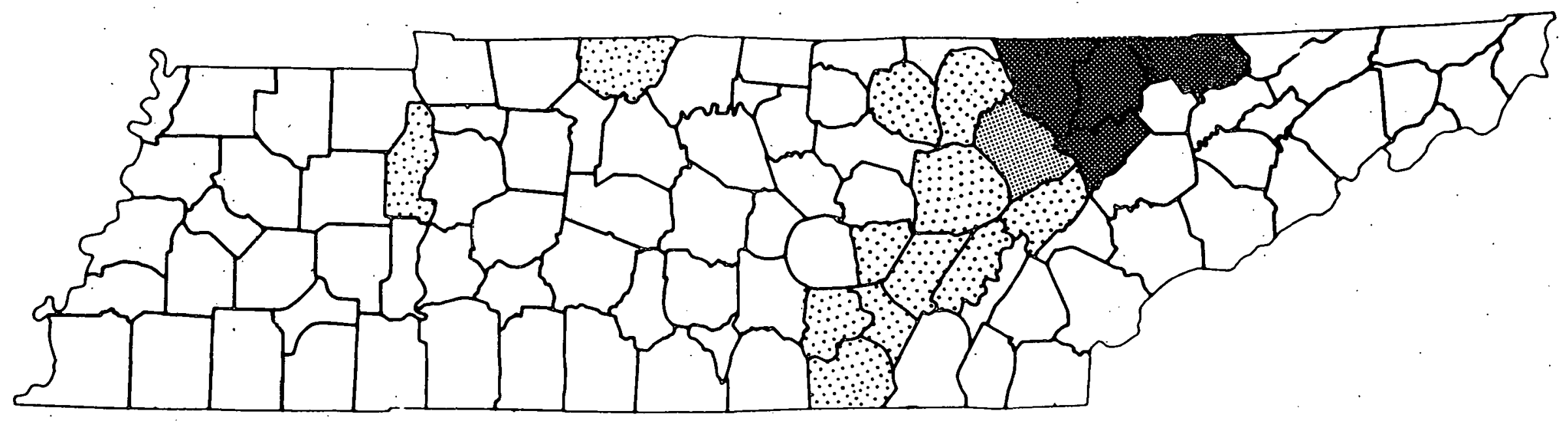

vs

Fig. B.38 Tennessee: Coal Production in 1979 
Table B.39 Texas: Cóal Quality Data

COUNTY
NAMES
FREESTONE
HCFKINS
PANELA

\begin{tabular}{|c|c|}
\hline $\begin{array}{l}\text { AVE SCO SC2 } \\
\text { CCNTENT } \\
\text { (LSS/METU) }\end{array}$ & $\begin{array}{l}\text { AVE ASH } \\
\text { COATENT } \\
\text { (PERCEAT) }\end{array}$ \\
\hline $\begin{array}{l}1.73 \\
1.96 \\
2.66\end{array}$ & $\begin{array}{l}10.40 \\
14.36 \\
10.00\end{array}$ \\
\hline
\end{tabular}
AVE. HEAT
VALUE
(BTU/LB)

6923.

6117.

ETES:
WASHABILITY DETA FERCEAT $S$ BTU LOSS REMCVAL

(PEP.CENT)

18.42

18.42

18.85
7.99

7.99

7.99 


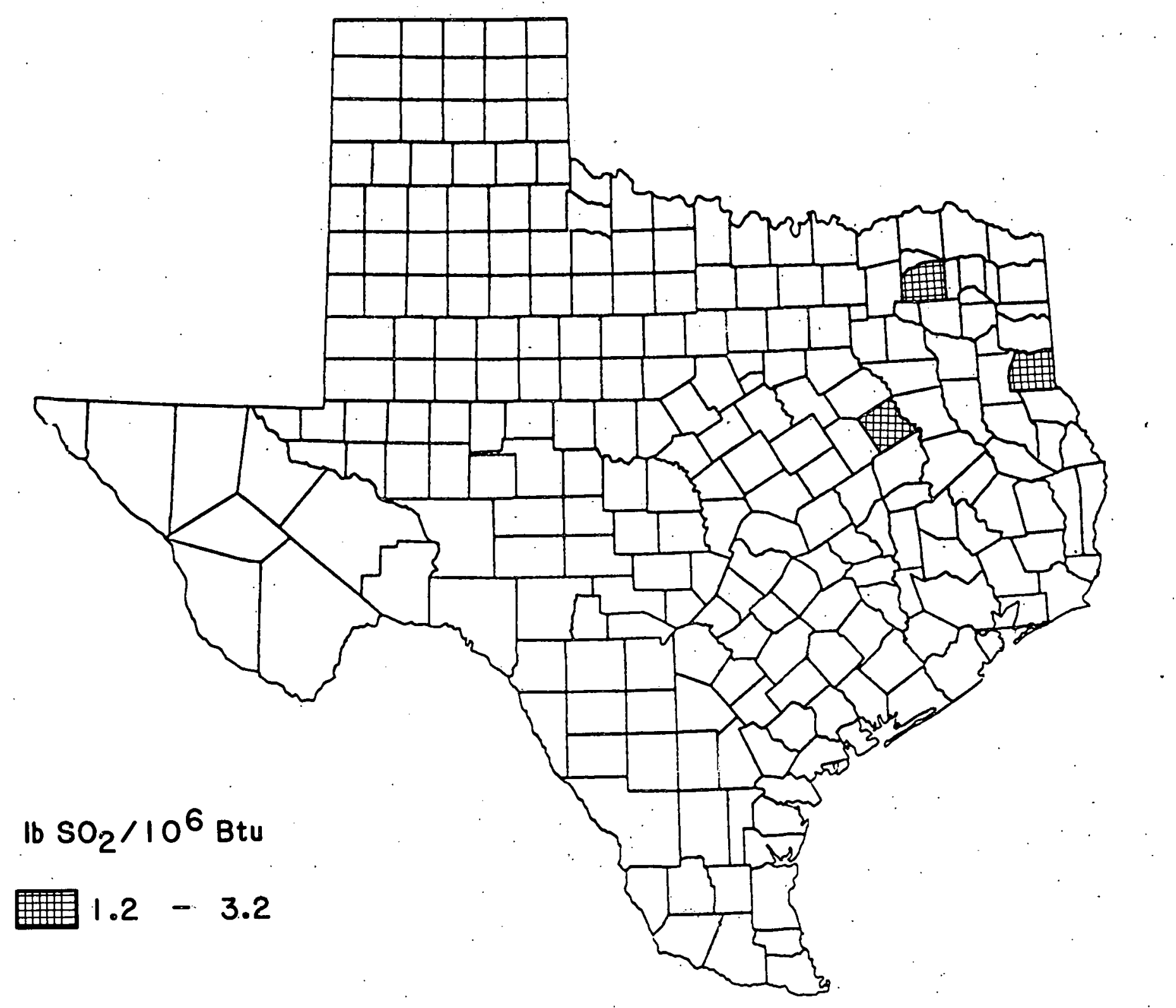

Fig. B.39 Texas: Average Sulfur Content of Coal 
Table B.40 Texas: Coal Production and Reserves Tonnage

\section{COUNTY \\ NAME}

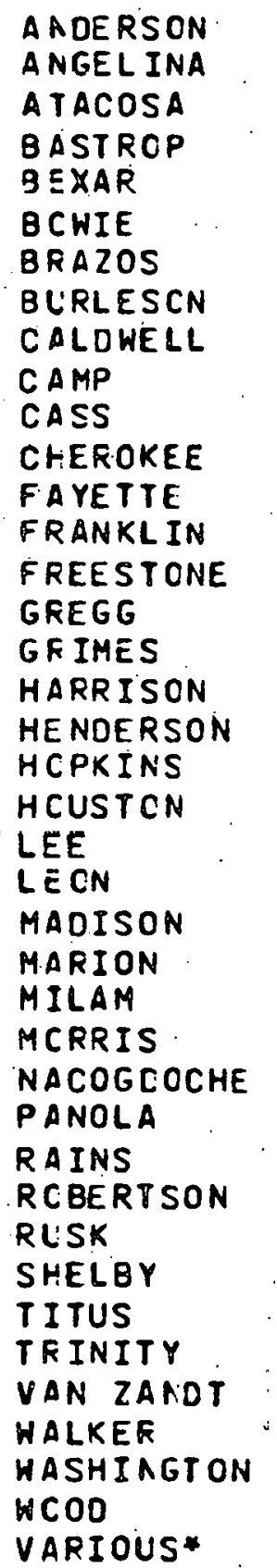

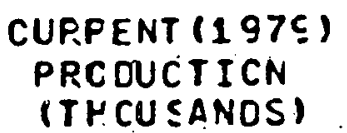

(THCU SANOS)

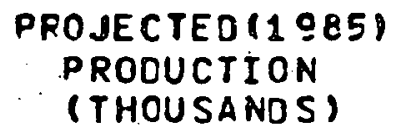

(THOUSANDS)
RESERVES

(PILL IONS)

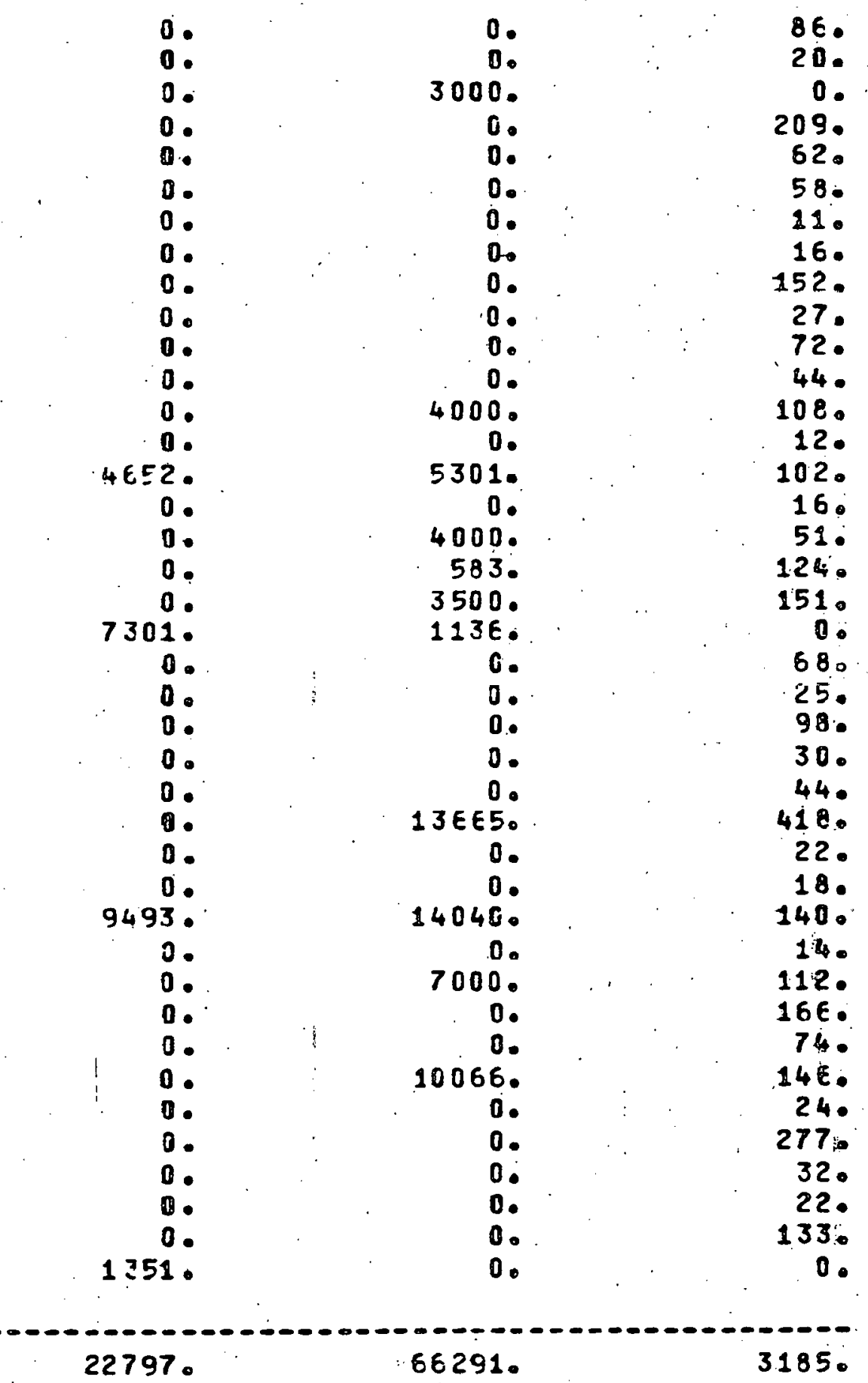

TOTAL 


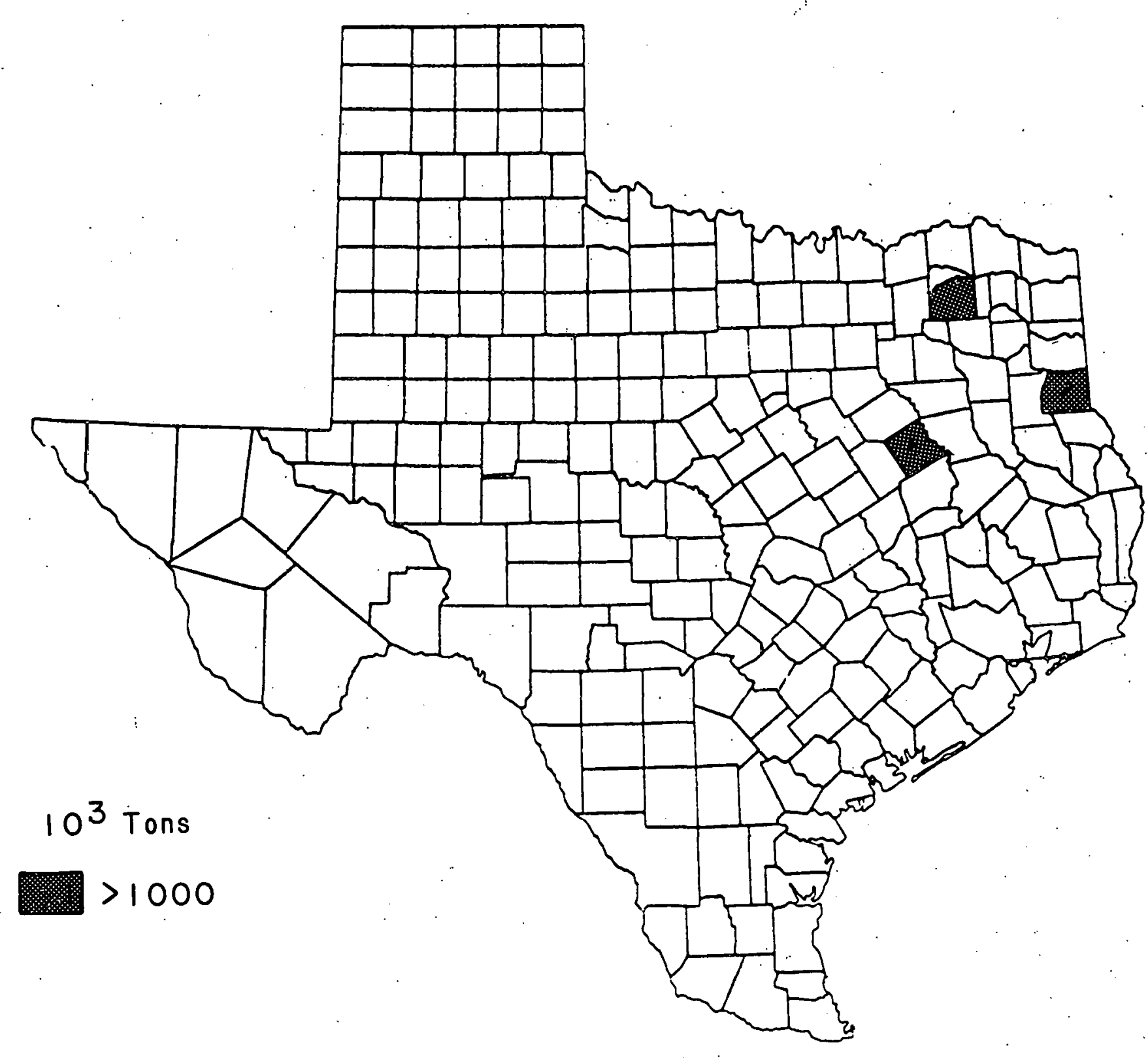

Fig. B.40 Texas: Coal Production in 1979 
Table B.4l Utah: Coal Quality Data

COUNTY.
NAMES
CARSON
ERERY
SALT LAKE
SEVIER
UTAH

$\begin{array}{lll}\text { AVE SC2 } & \text { AVE.ASH } & \text { AVE. HEAT } \\ \text { CCNTENT } & \text { CONTENT } & \text { VALUE } \\ \text { (LSSIMETU) } & \text { (PERCEATI } & \text { (BTU/LE) }\end{array}$

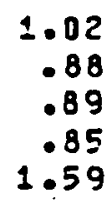

9. 67

10.89

7.00

9.64

18.55
11731 .

11742 .

11708 .

11176

10170 .
WASHAB IL ITY DATA PERCEAT $S$. BTU LOSS FEMCVAL

(PERCENT )

$$
\begin{array}{r}
9.36 \\
3.39 \\
5.87 \\
10.25 \\
5.16
\end{array}
$$

$$
\begin{array}{r}
2.40 \\
.72 \\
1.36 \\
2.62 \\
2.40
\end{array}
$$




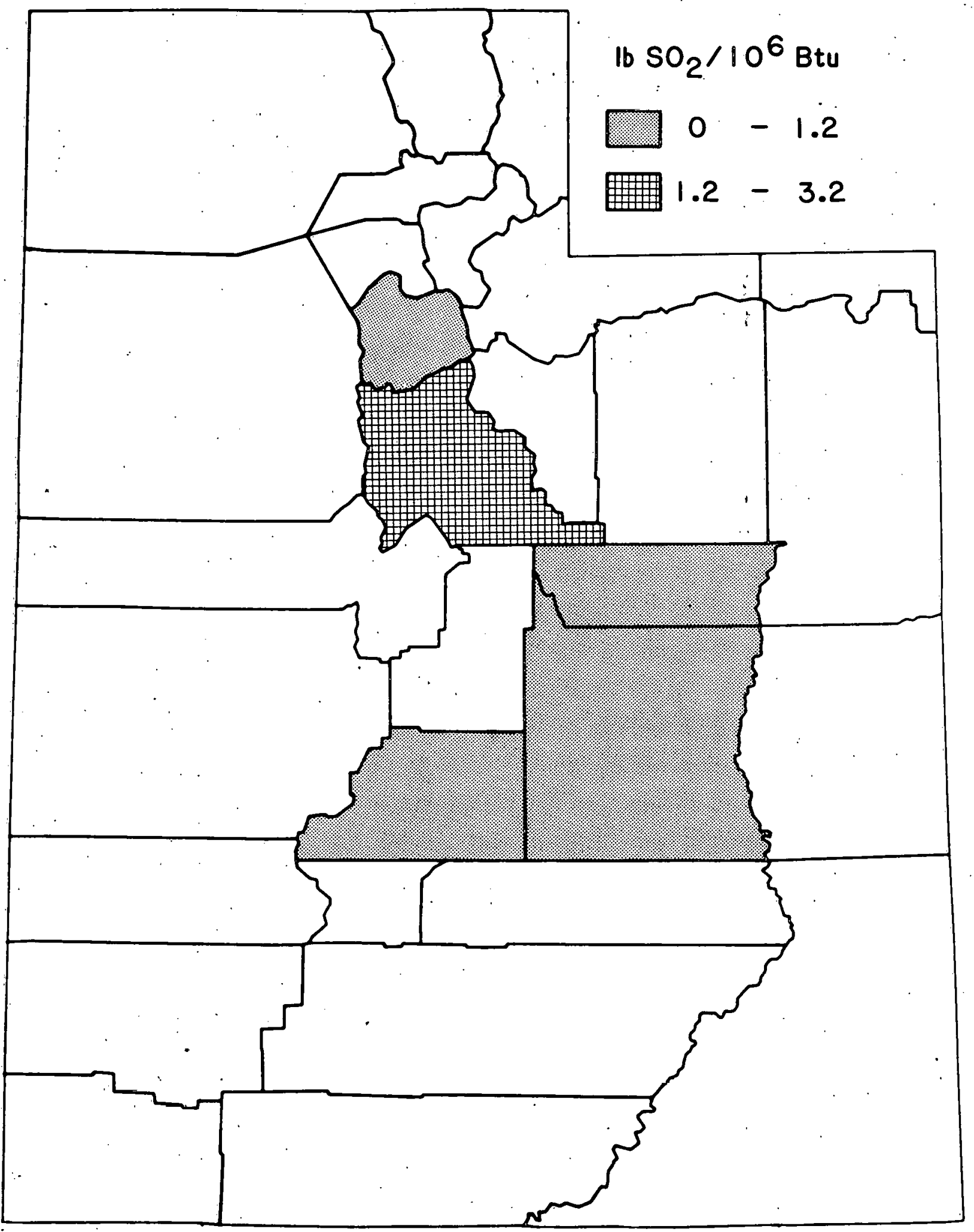

Fig. B.4l Utah: Average Sulfur Content of Coal 
Table B.42 Utah: Coal Production and Reserves Tonnage

COUNTY

NAME

CARBON

ERERY

GARF IELD

I RON

KANE

SEVIER

UINTAH

UTAH

HAYNE

VARIOUS*

TOTAL
CURFENT (197C) PFO JECTEO(1985)

PRCDUCTICN

(THCUSANDS)

(THCUSANOS)
15855.

$16061 \%$

0 .

0 .

0 。

6853.

C.

1000

0 .
RESEFVES

(PILL IONS)

$$
\begin{array}{r}
2520 \\
3375 \\
0 \\
0 \\
0 \\
103 \\
0 \\
6 \\
0 \\
964
\end{array}
$$

6968 .

39769.

4041 .

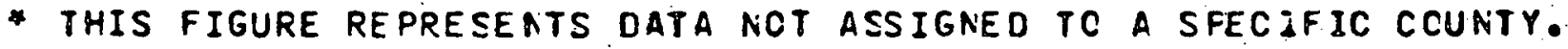




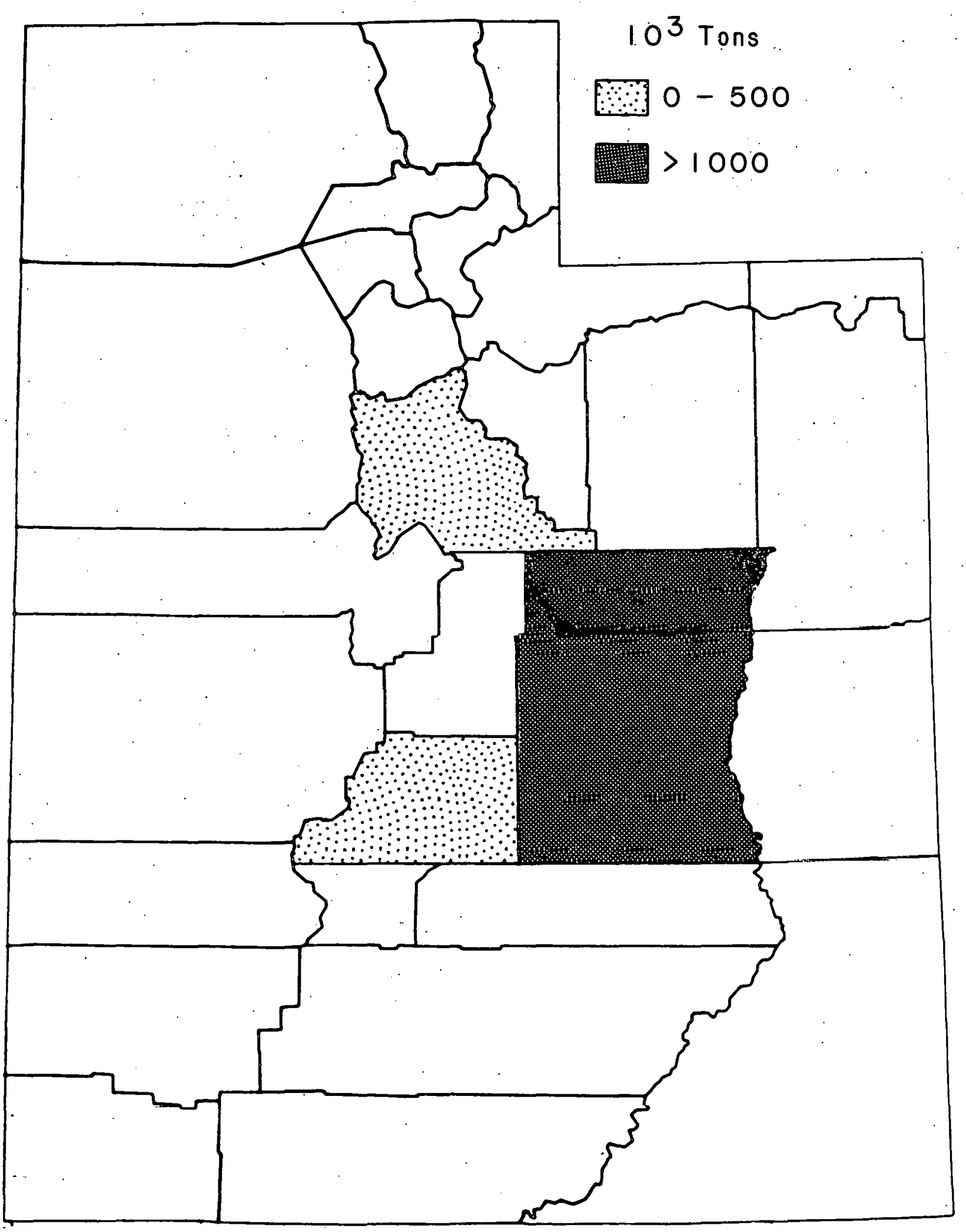

Fig. B.42 Utah: Coal Production in 1979 
Table B.43 Virginia: Coal Quality Data

$\begin{array}{lr}\text { COUNTY } & \text { AVE SOR } \\ \text { NAMES } & \text { CONTENT } \\ \text { ILBS/MBTU } & \\ \text { ALLEGHENY } & 1.69 \\ \text { BLANO } & 1.56 \\ \text { BUCHANAN } & 1.7 E \\ \text { CAMFEELL } & 1.02 \\ \text { OICKEASON } & 2.32 \\ \text { FAIRFAX } & 1.67 \\ \text { GREENESVIL } & 1.55 \\ \text { LEE } & 1.99 \\ \text { RUSSELL } & 1.33 \\ \text { TAZENELL } & 1.32 \\ \text { WISE } & 1.46\end{array}$

$$
\begin{array}{ll}
\text { AVE. ASH } & \text { AVE RIEAT } \\
\text { CONTENT } & \text { VALUE } \\
\text { (PERCEAT) } & \text { (BTU/LS) }
\end{array}
$$

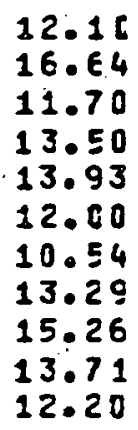

11250 . 116450 12432 . 12560 . 12303. 12000 . 12760 . 12161. 1.2163。 12269. 12329.
WASHABIL ITYY DATA FERCEAT S BTU LOSS REMCVAL (PERCENT)

16.95
14.02
9.52
16.41
17.70
16.66
.00
15.57
5.49
13.04
6.96

4.74

4.91

2.99

4.69

5.62

4.66

.00

4.50

2.89

3.77

2.52 


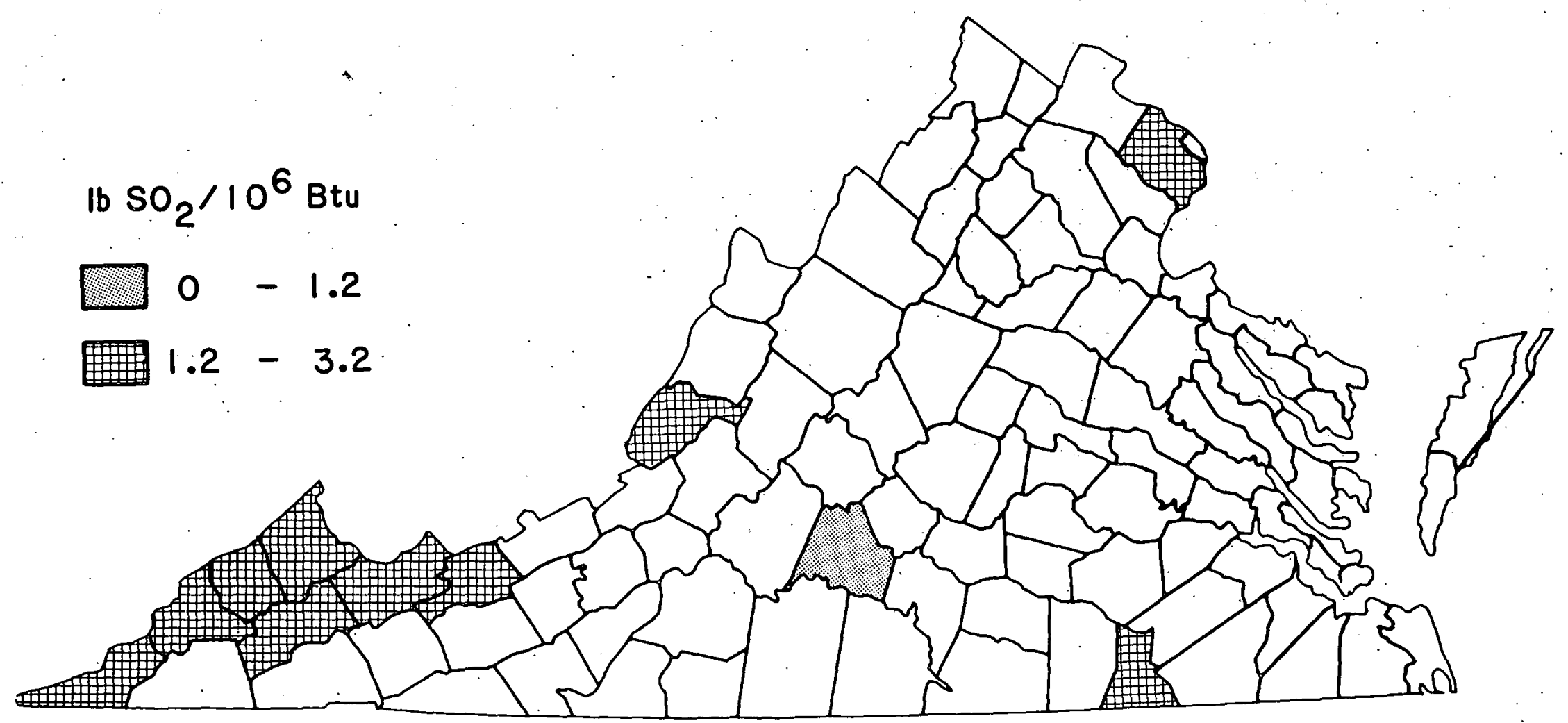

s

Fig. B.43 Virginia: Average Sulfur Content of Coal 
Table B.44 Virginia: Coal Production and Reserves Tonnage

COUATY

NAME

ALLEGHENY

BLCHA PAN

CAMPEELL

O ICKEASON

F A IRFAX

GREENESVIL

LEE

MCNT GCMERY

PLLASKI

RUSSELL.

SCOTT

T DZE HELL

WISE

VARIOUS*

TOTAL

$\begin{array}{lc}\text { CURRENT (1979) } & \text { PROJECTEO(1985) } \\ \text { PRCOUCTION } & \text { ORODUCTION } \\ \text { (THCUSANOS) } & \text { (THCUSANOS) }\end{array}$

(THCUSANOS)
RESERVES

(MILL JONS)

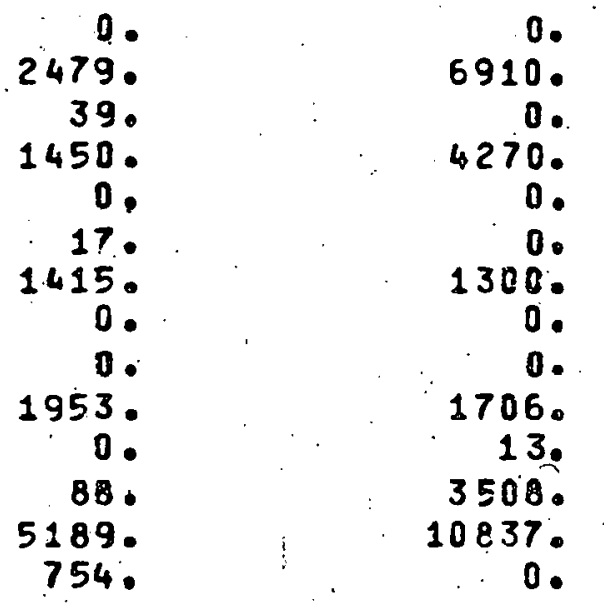

1073

0.

577 .

0 .

0.

229.

72 .

65.

455 。

44.

213.

907 .

0 .

* this figure represents data not assigneo to a specific county. 


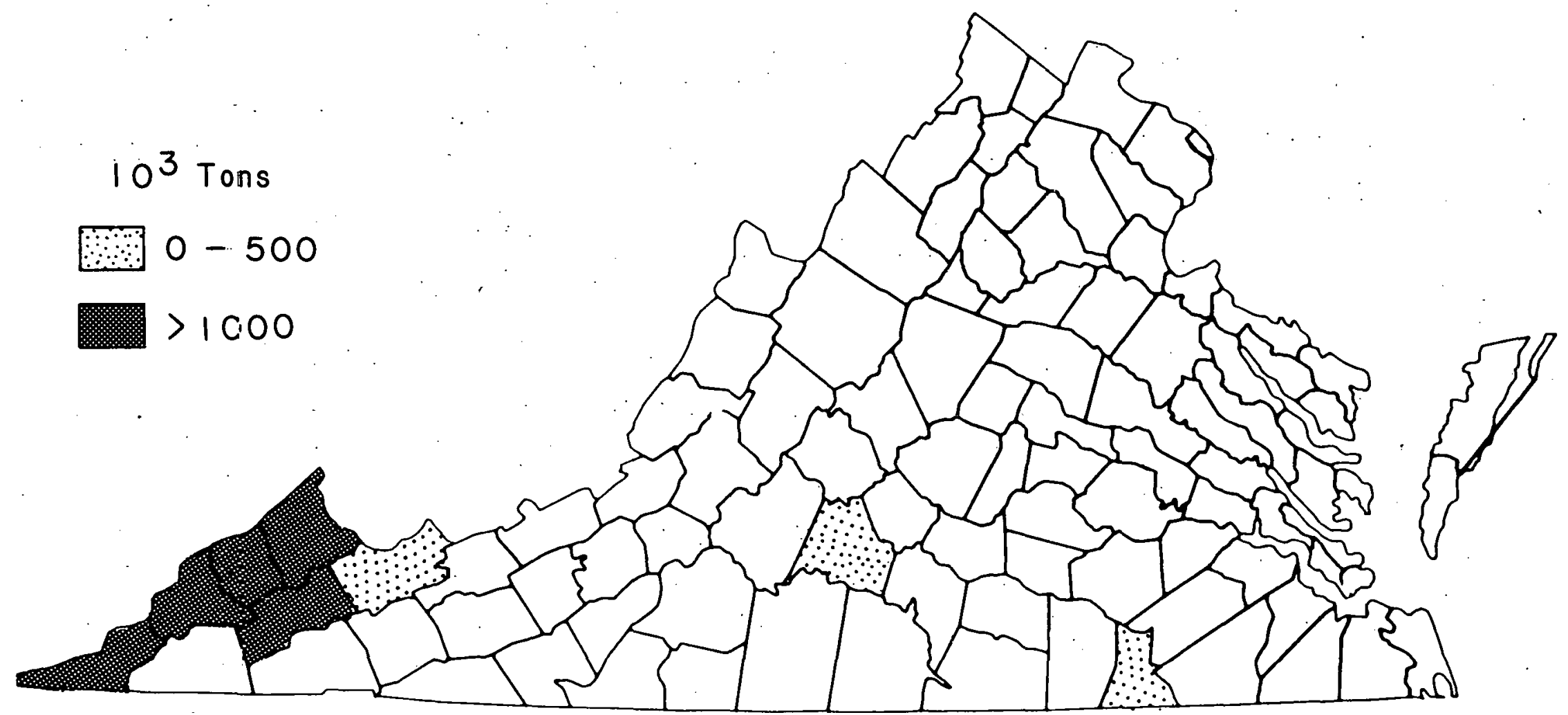

Fig. B.44 Virginia: Coal Production in 1979 
Table B.45. Washington: Coal Quality Data

$\begin{array}{cccc}\text { COUNTY } & \text { AVE. SO2 } & \text { LVE. ASH } & \text { AVE. HEAT } \\ \text { NAMES } & \text { COATENT } & \text { CONTENT } & \text { VALUE } \\ \text { (LBS/METU) } & \text { (PEFCENT) } & \text { (BTU/LB) } \\ \text { LEWIS } & 2.19 & 15.95 & \end{array}$

WASHABILITY OATA
PERCEAT S BTU LOSS
FENCVAL S (PERCENT)
.78




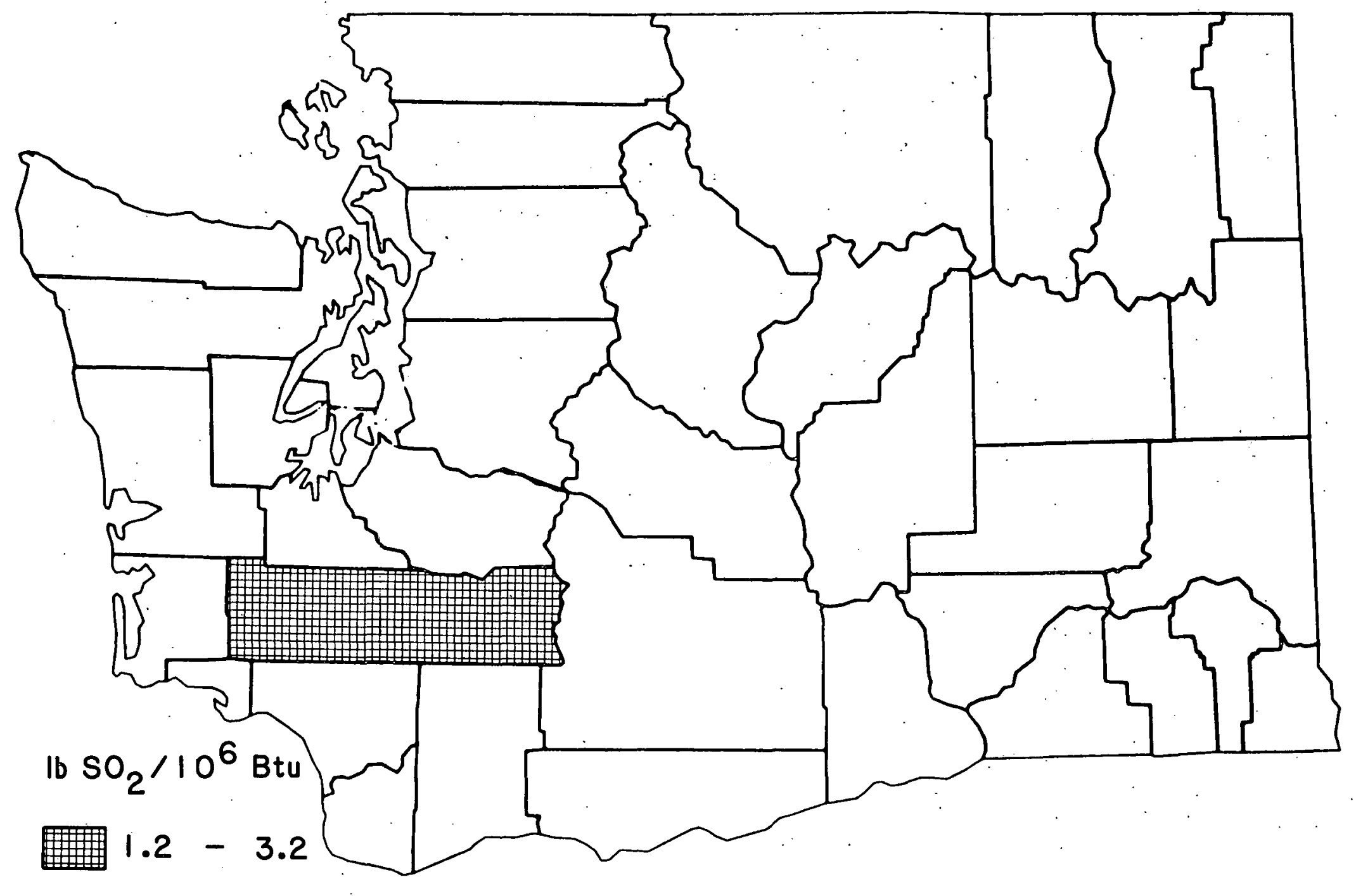

Fig. B.45 Washington: Average Sulfur Content of Coal 
Table B.46 Washingtion: Coal Production and Reserves Tonnage

\section{COUNTY}

NAME

KING

KITTITAS

LEWIS

PIERCE

THURSTCN

HFATCCM

VARIOUS*

TCTAL

\section{CURRENT (1979) PROJECTEO(1985)}

PRODUCTION

(THCUSANOS)
PROOUCTION

(THOUSANDS)
RESEPVES

(NILLIONS)

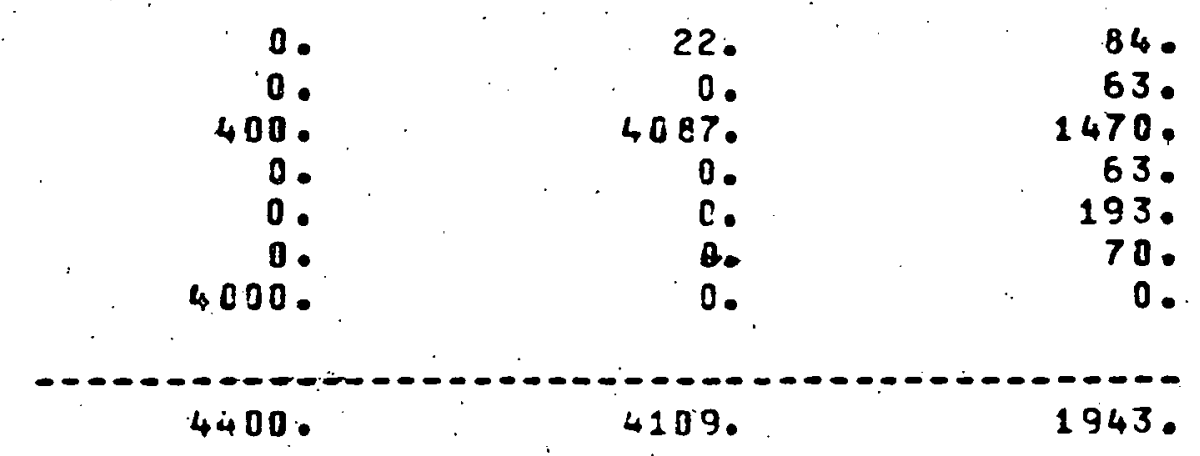

* this figure represents data not assigned to a specific county. 


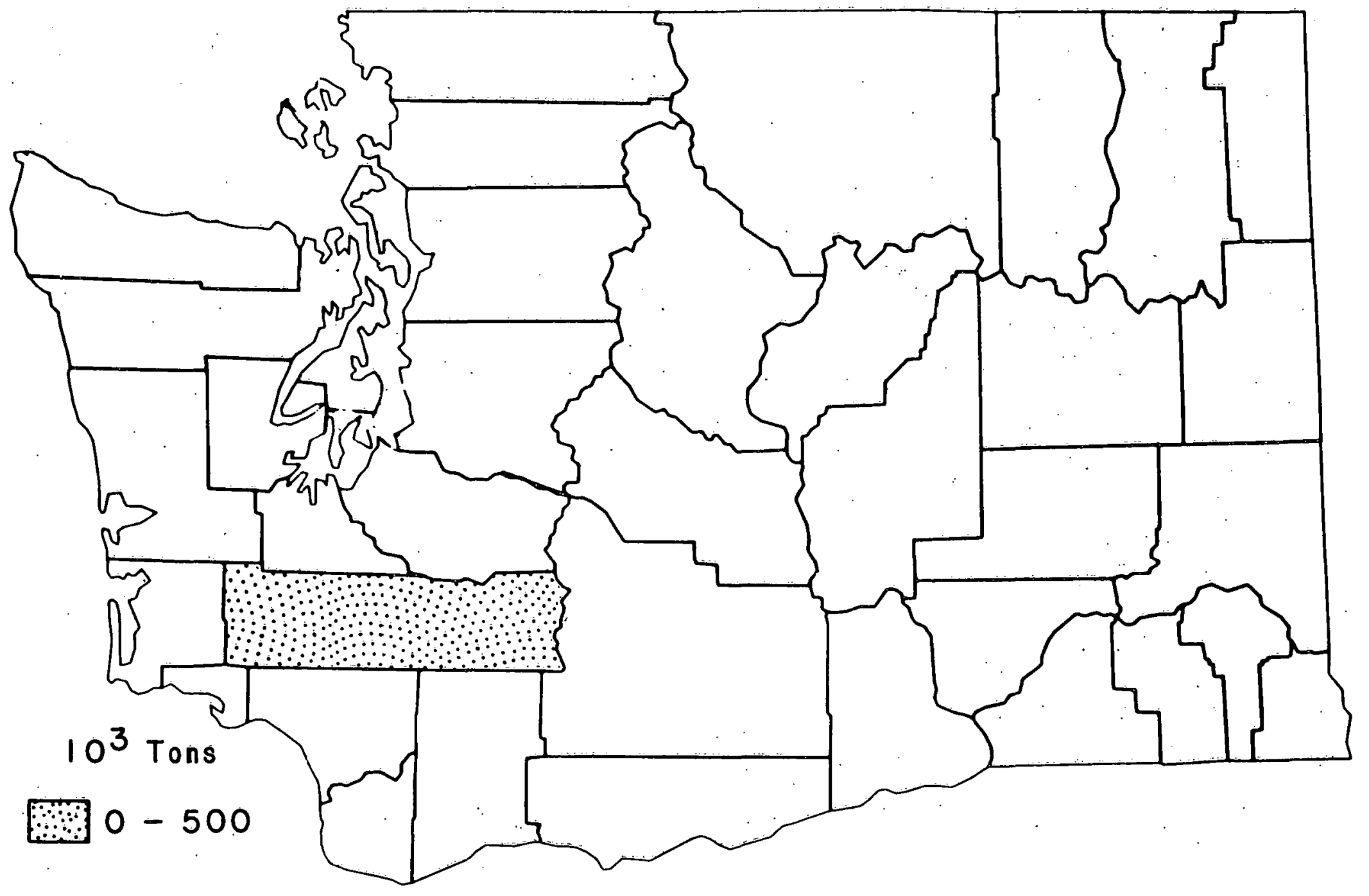

Fig. B.46 Washington: Coa1 Production in 1979 
Table B.47 West Virginia: Coal Quality Data

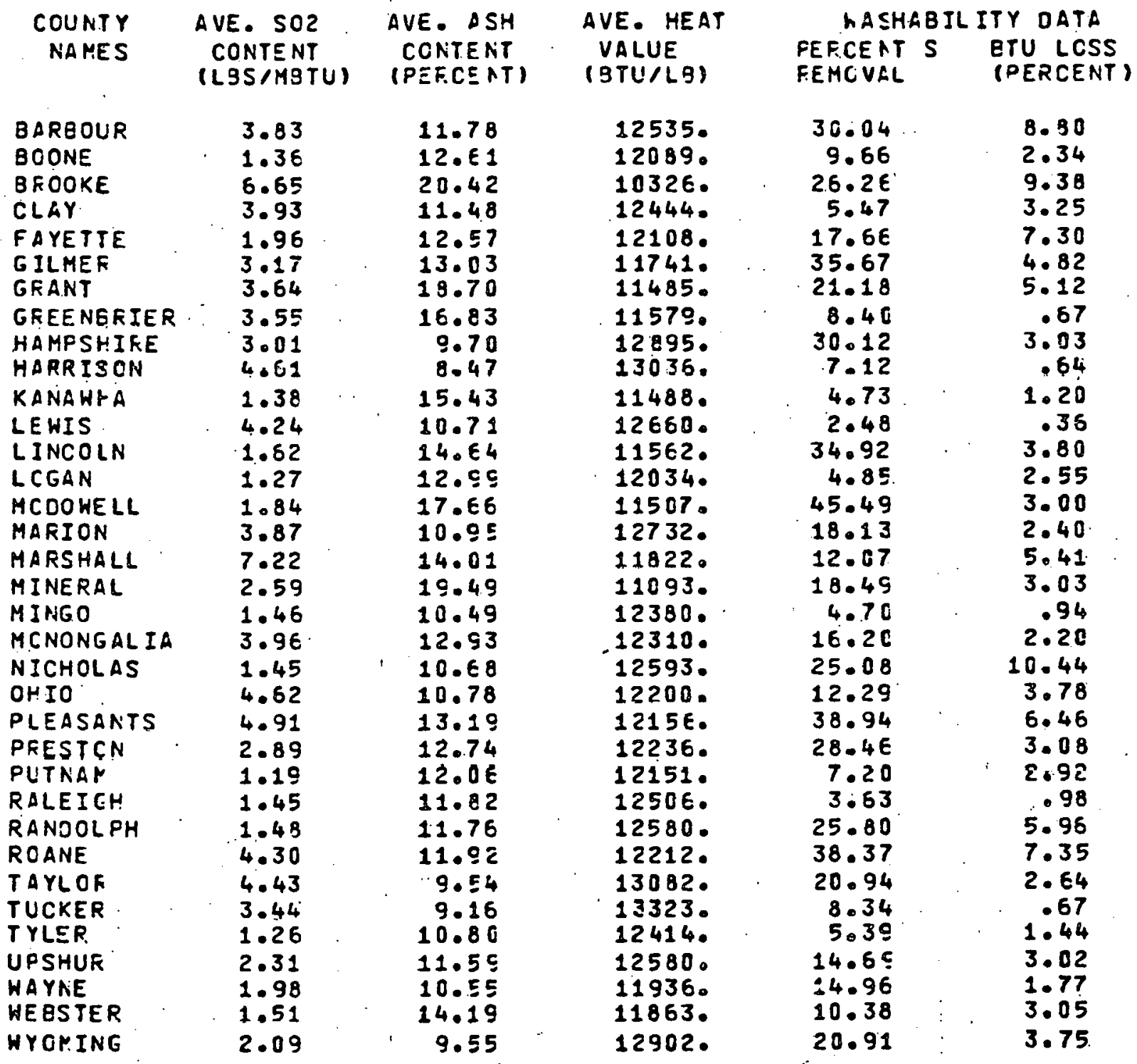




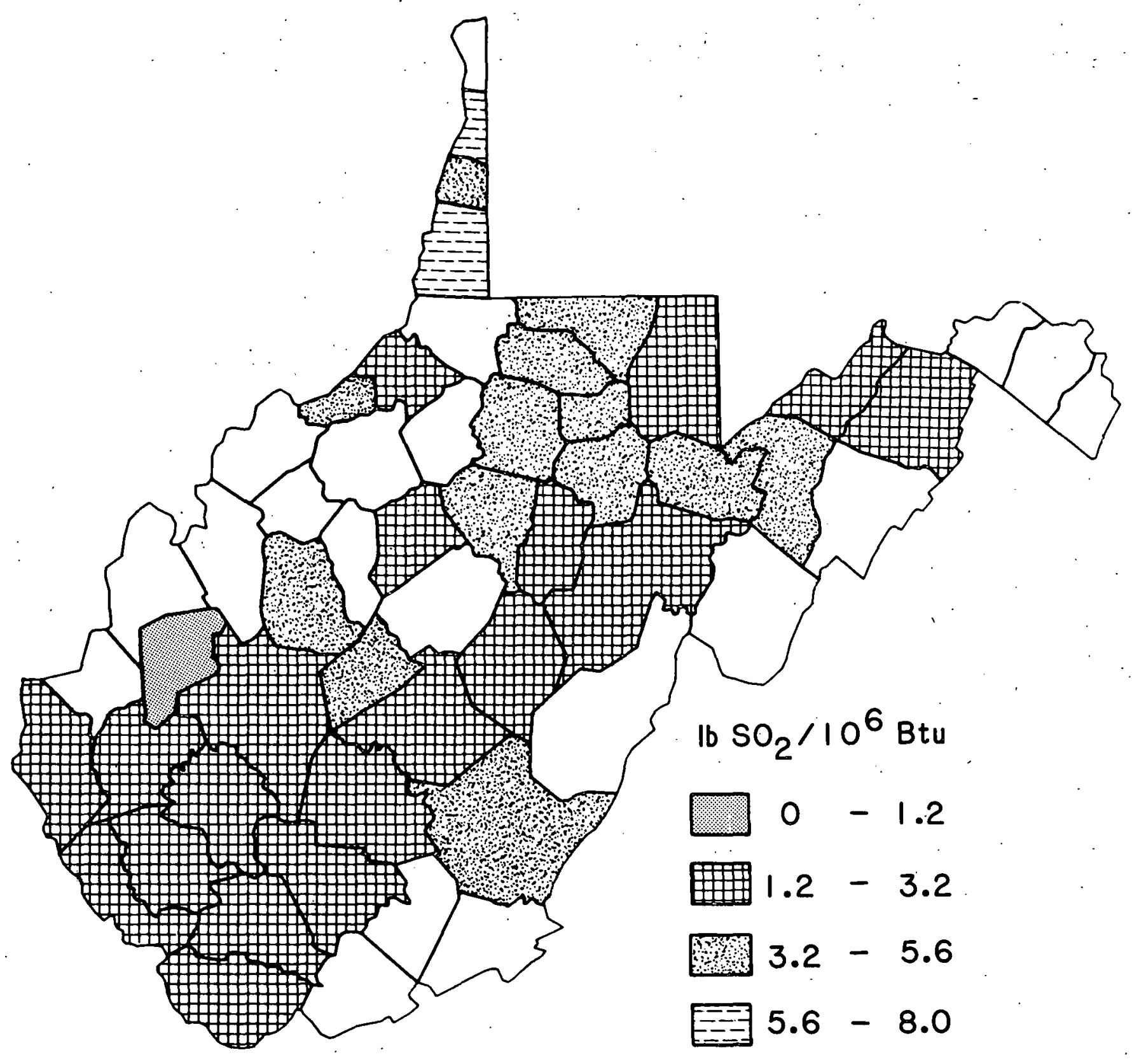

Fig. B.47 West Virginia: Average Sulfur Content of Coal 
Table B.48 West Virginia: Coal Production and Reserves Tonnage

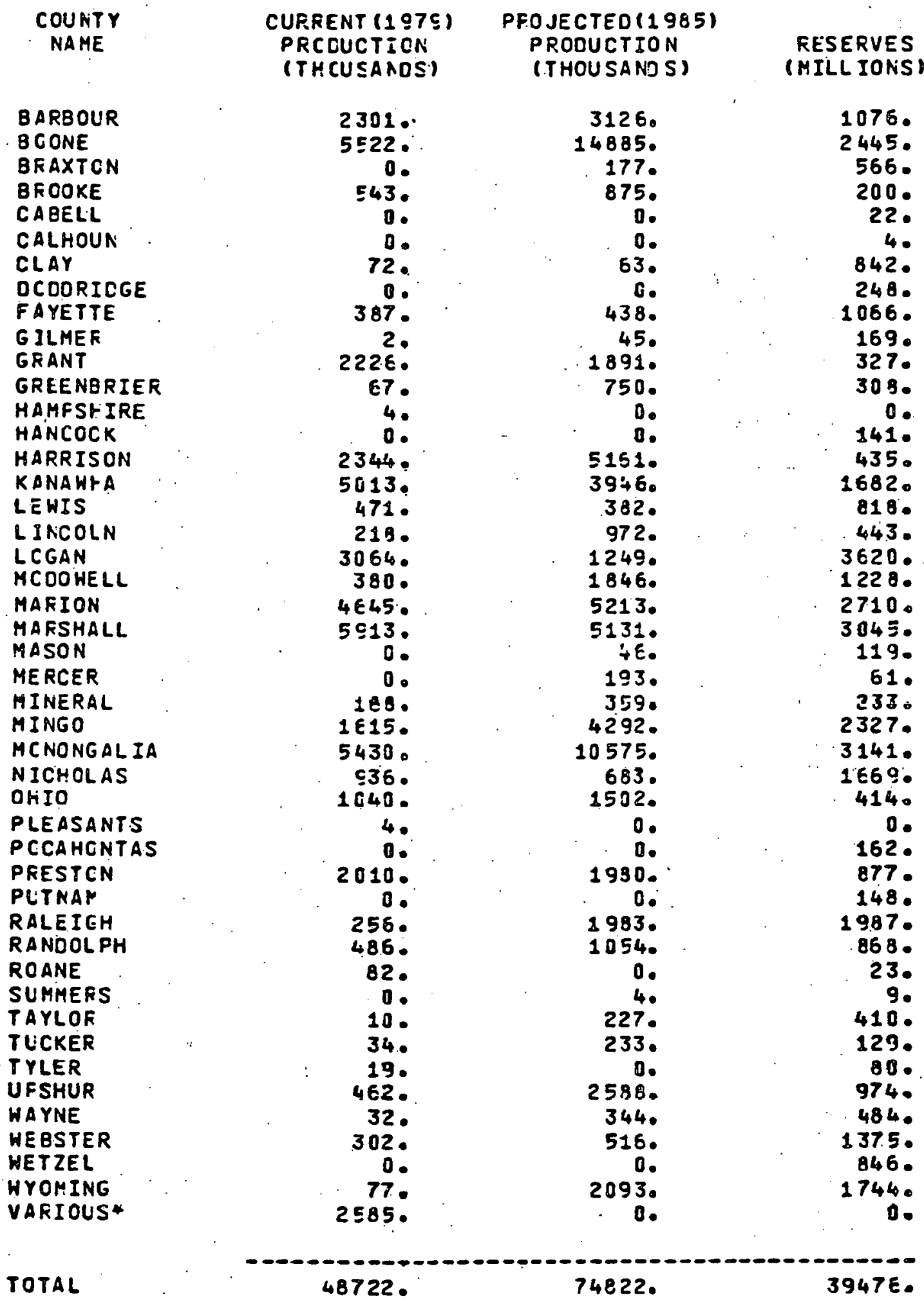

* thIS fIgURE REPRESEATS DATA NOT ASSIGNEO TO A SFECIFIC CCUNTY. 


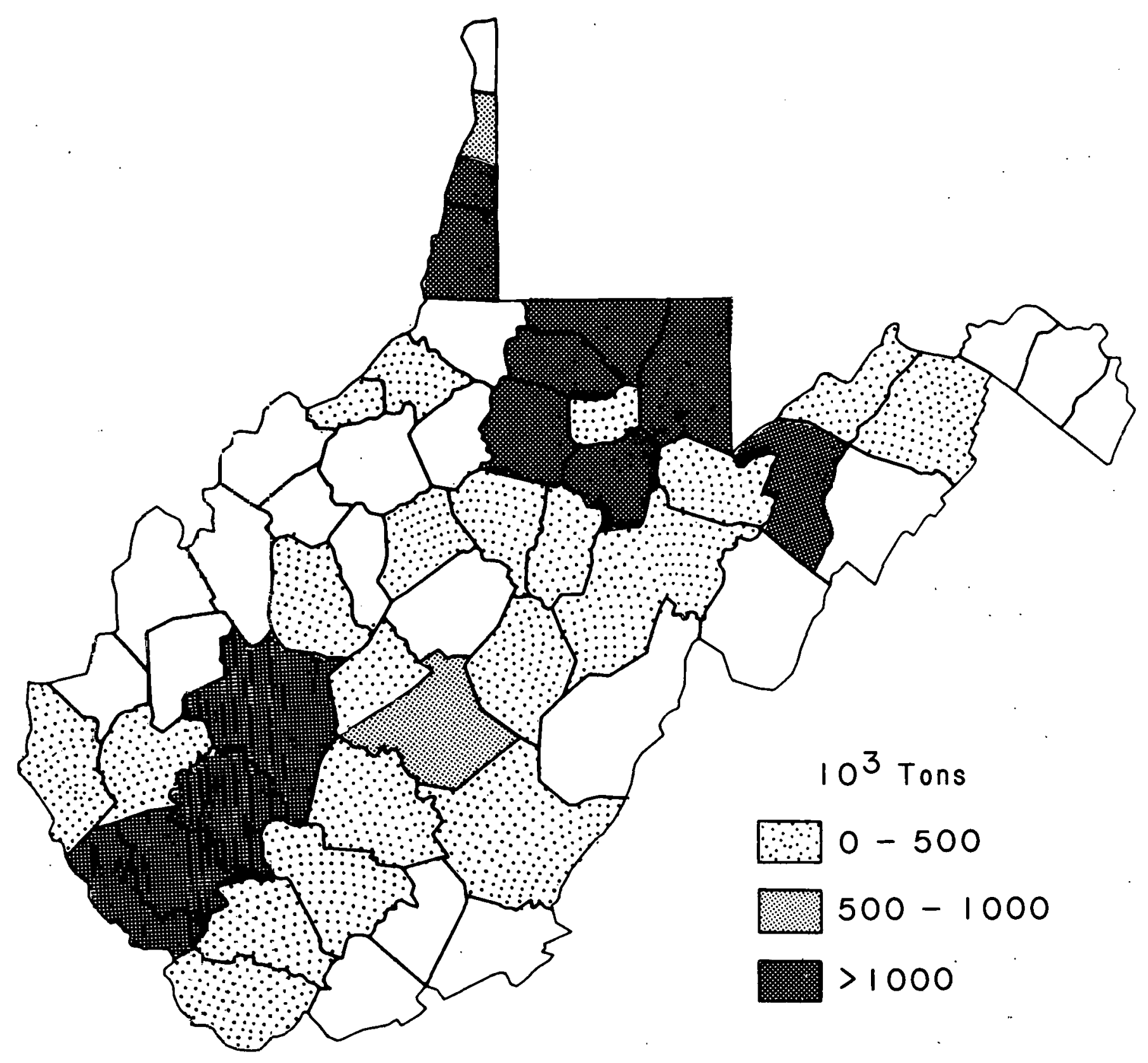

Fig. B.48 West Virginia: Coal Production in 1979 
Table B.49 Wyoming: Coal Quality Data

$\begin{array}{lcr}\begin{array}{c}\text { COUNTY } \\ \text { NAMES }\end{array} & \begin{array}{c}\text { AVE SOL } \\ \text { CONTENT } \\ \text { (LES/MBTU) }\end{array} & \begin{array}{r}\text { AVE ASH } \\ \text { COATENT } \\ \text { (PERCENT }\end{array} \\ \text { BIG HCEN } & 1.01 & 4.08 \\ \text { CAMPEELL } & .94 & 5.41 \\ \text { CARZON } & 1.42 & 11.31 \\ \text { CCNVERSE } & 1.11 & 8.68 \\ \text { LINCOLN } & 1.09 & 5.20 \\ \text { PARK } & .85 & 5.15 \\ \text { SHEETWATER } & 1.06 & 11.11\end{array}$
AVE. HEAT
VALUE
(BTU/LB)

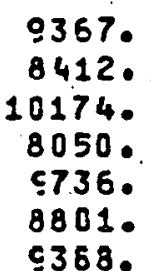

9367.

8412.
10174.

8050 .

8801.

c368.
WASHABILITY OATA FERCEAT S BTU LOSS REMCVAL

(PERCENT)

$$
\begin{array}{r}
6.18 \\
10.21 \\
3.24 \\
8.51 \\
21.64 \\
1.80 \\
12.96
\end{array}
$$

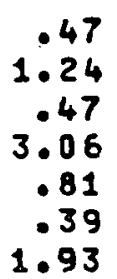

.47 .47 .06 .39 1.93 


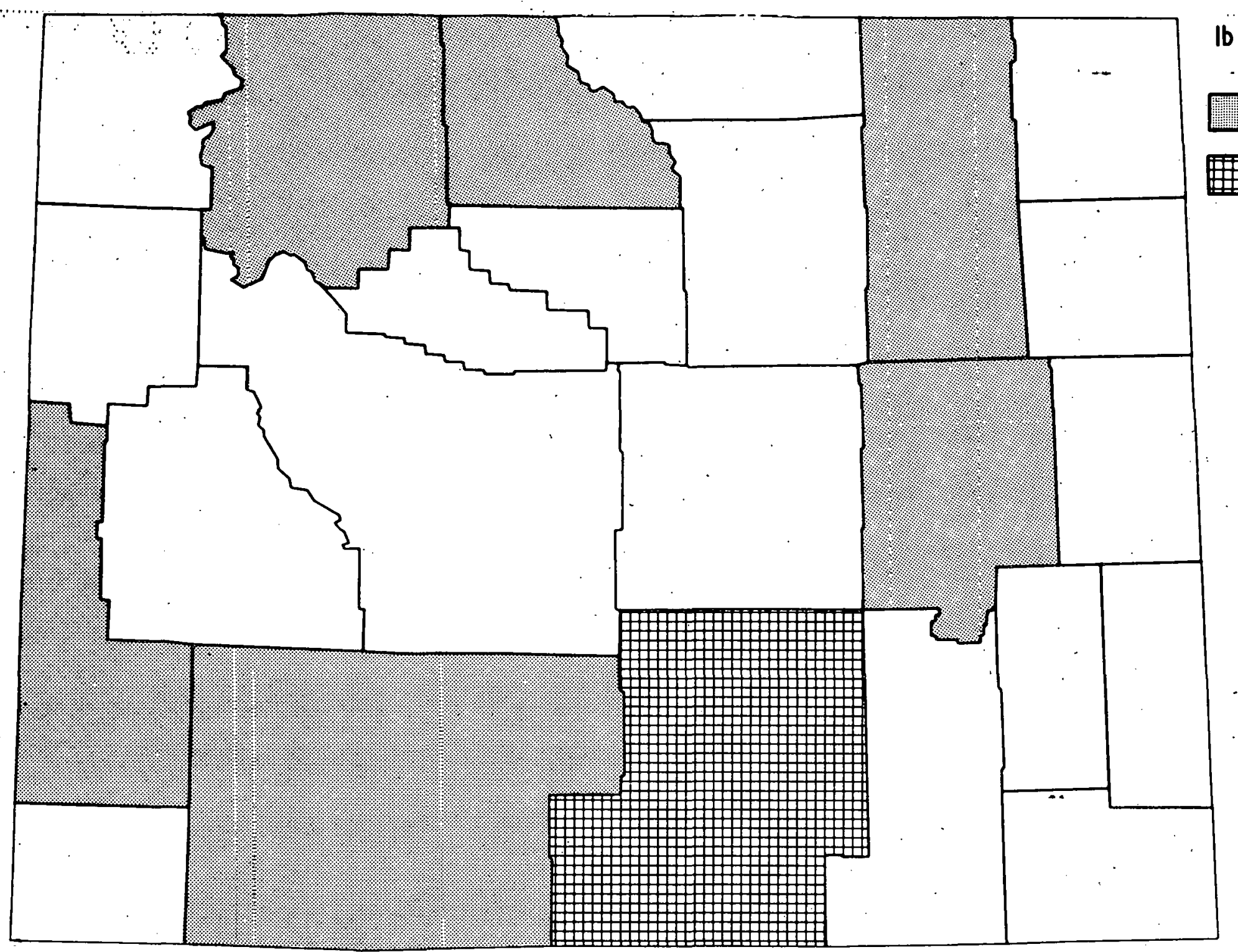

$16 \mathrm{SO}_{2} / 10^{6} \mathrm{Btu}$

$\begin{array}{lll}0 & -1.2\end{array}$

$1.2-3.2$

Fig. B.49 Wyoming: Average Sulfur Content of Coal 
Table B.50 Wyoming: Coal Production and Reserves Tonnage

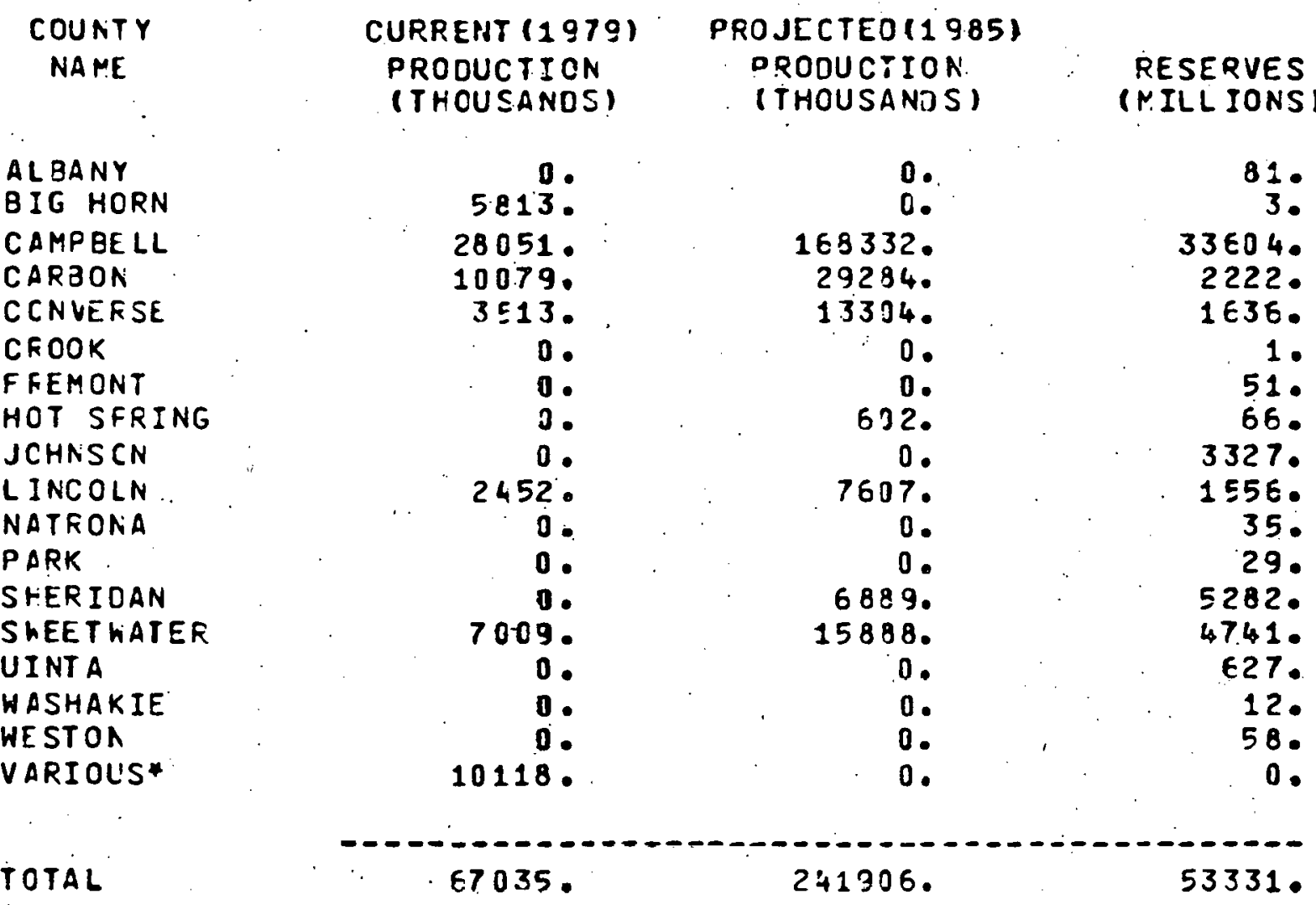

* this figure represents data not assigned to a sfecific ccuntr. 


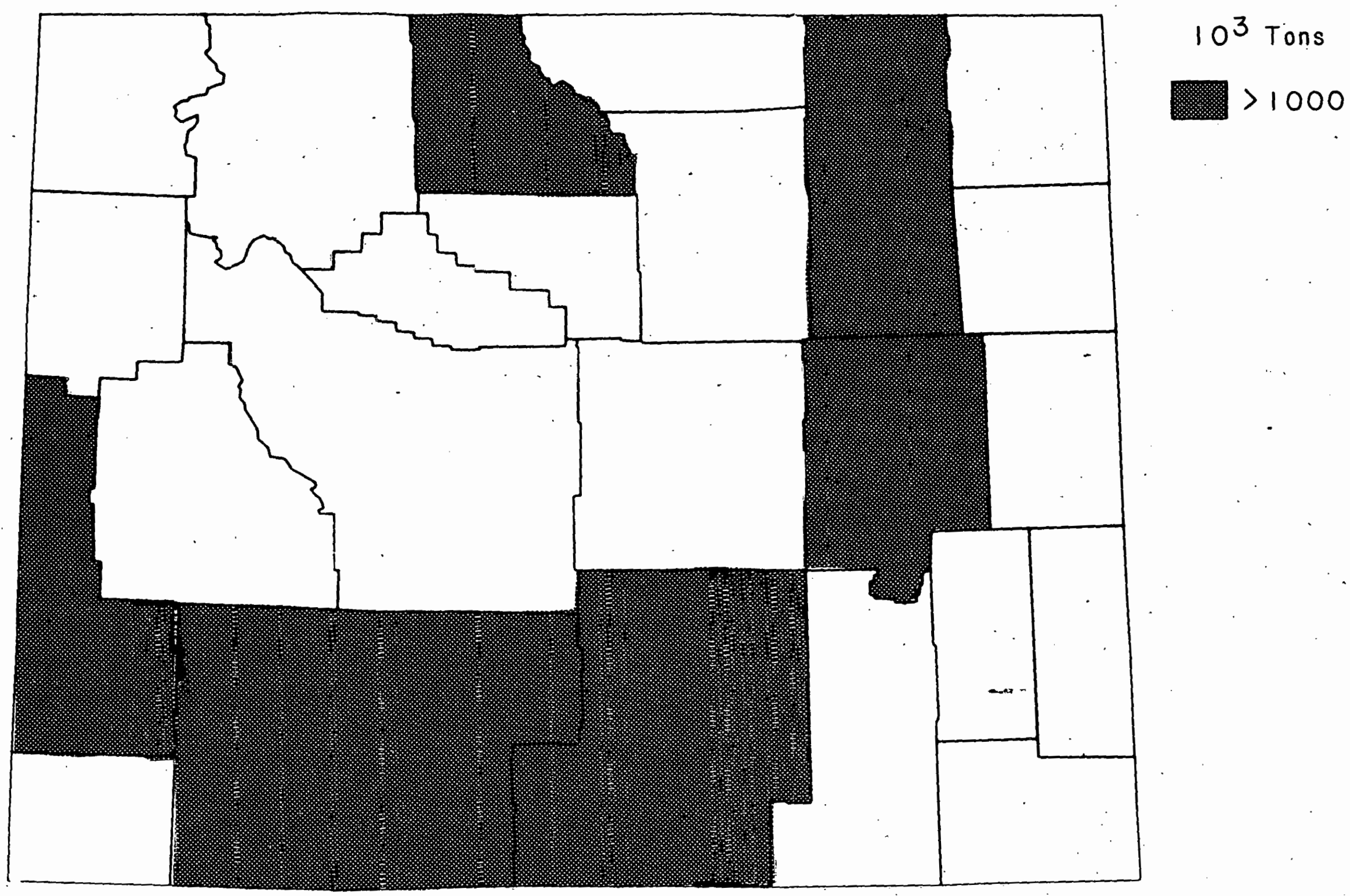

Fig. B.50 Wyoming: Coal Production in 1979 
Table B.51 Michigan: Coal Production and Reserves Tonnage

\begin{tabular}{|c|c|c|c|}
\hline $\begin{array}{l}\text { COUNTY } \\
\text { NAME }\end{array}$ & $\begin{array}{l}\text { CUREENT (197S) } \\
\text { PRCCUCTICA } \\
\text { (THCUSANOS) }\end{array}$ & $\begin{array}{l}\text { FRO JECTED (1985) } \\
\text { PRODUCTION } \\
\text { (THOUSANDSI }\end{array}$ & $\begin{array}{l}\text { FESERVES } \\
\text { (PILLION'S) }\end{array}$ \\
\hline $\begin{array}{l}\text { BAY } \\
\text { GENESSEE }\end{array}$ & 0. & 0. & 56. \\
\hline $\begin{array}{l}\text { HURON } \\
\text { SAGINAW } \\
\text { SHIAWASSEE }\end{array}$ & $\begin{array}{l}0 . \\
0: \\
0 .\end{array}$ & $\begin{array}{l}0 . \\
0 . \\
0 .\end{array}$ & $\begin{array}{r}6 \\
27 \\
2\end{array}$ \\
\hline TUSCOLA & 0 . & 0. & 20. \\
\hline
\end{tabular}

Table B.52 Oregon: Coal Production and Reserves Tonnage

\begin{tabular}{|c|c|c|c|}
\hline $\begin{array}{l}\text { COUNTY } \\
\text { NAME }\end{array}$ & $\begin{array}{l}\text { CURFENT (1970) } \\
\text { PRCDUCTION } \\
\text { (THCUSANOS) }\end{array}$ & $\begin{array}{l}\text { PRO JECTEO }(1985) \\
\text { PRODUCTION } \\
\text { (THOUSANDS) }\end{array}$ & $\begin{array}{l}\text { RESERVES } \\
\text { (MILLIONS) }\end{array}$ \\
\hline $\cos$ & o. & 0. & 2. \\
\hline
\end{tabular}

Table B.53 South Dakota: Coal production and Reserves Tuniage

$\begin{array}{ccc}\text { COURTY } & \text { CURFENT(197S) } & \text { PROJECTEO(1985) } \\ \text { NAME } & \text { PRCOUCTICN } & \text { PFODUCTION } \\ & \text { (THCUSANDS) } & \text { (THOUSANOS) }\end{array}$

RF.SERVES

(MILL IONS)

CORSON

DEWEY

HARDING

PERKINS

ZEISACH

$\begin{array}{lll}0 & 1 & 0 . \\ 0 & & 0 . \\ 0 & 0 \\ 0 & 0 & 0 . \\ 0 & & 0 .\end{array}$

30.

130.

227.

40 .

1.

TOTAL

0 .

0.

428. 
$-$ 


\section{THIS PAGE}

WAS INTENTIONALLY

LEFT BLANK 


\section{APPENDIX C}

MAPS OF. PSD CLASS I AREAS

The following maps present the boundaries of each mandatory prevention of significant deterioration Class I area, on a state-by-state basis. A cover sheet for each state lists the names of the Class I areas, their acreage, and their location on the map. Several Class I areas (e.g., Yellowstone National Park) have acreage in more than one state and appear on more than one map. 
Table C.1. Alabama: PSD Class I Area

\begin{tabular}{ccc}
\hline Location & Area Name & Acreage \\
\hline 1 & Sipsey Wilderness & 12,646 \\
\hline
\end{tabular}




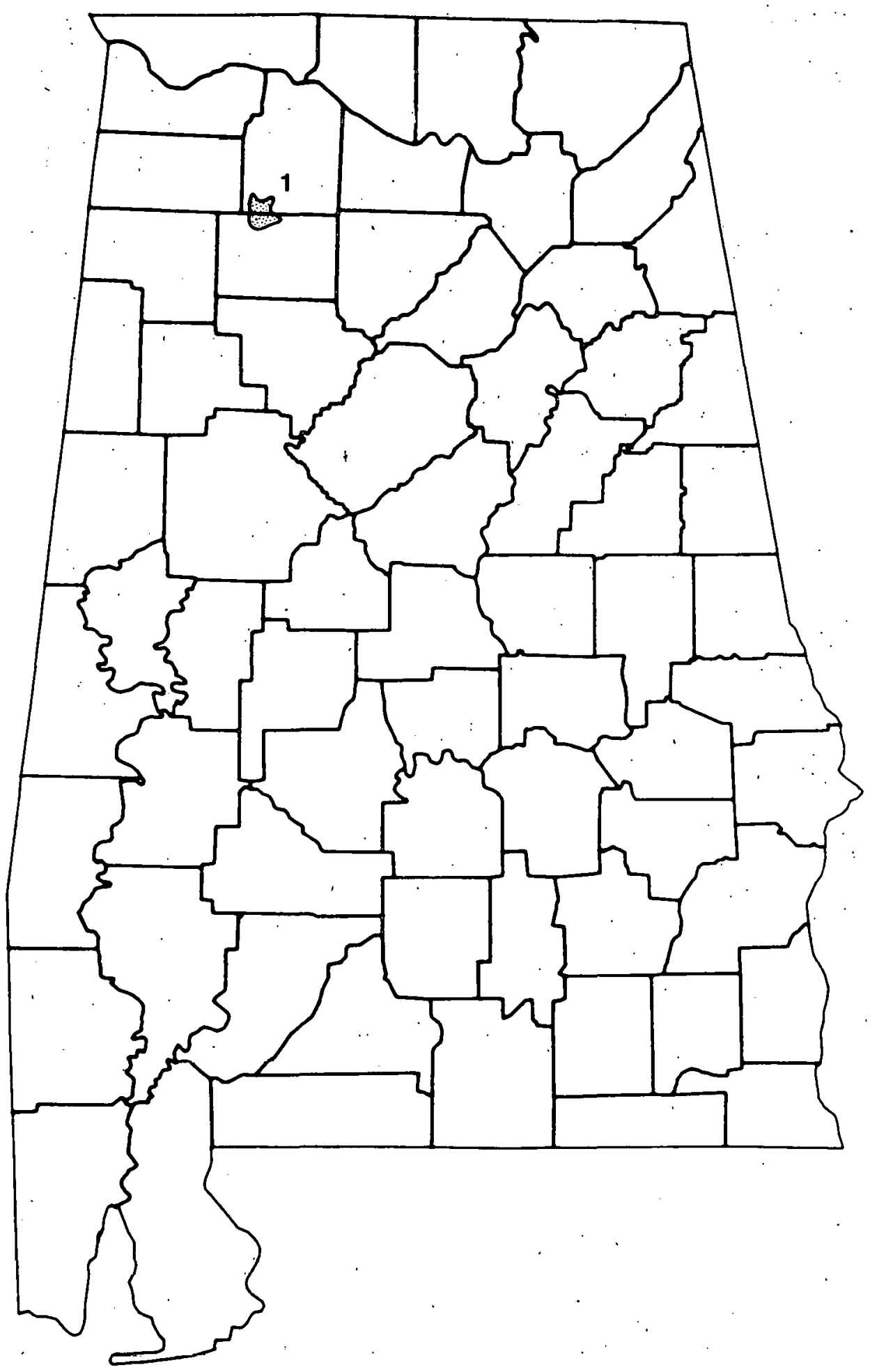

Fig. C.1 Alabama: PSD Class I Areas 
Table C.2 Arizona: PSD Class I Areas

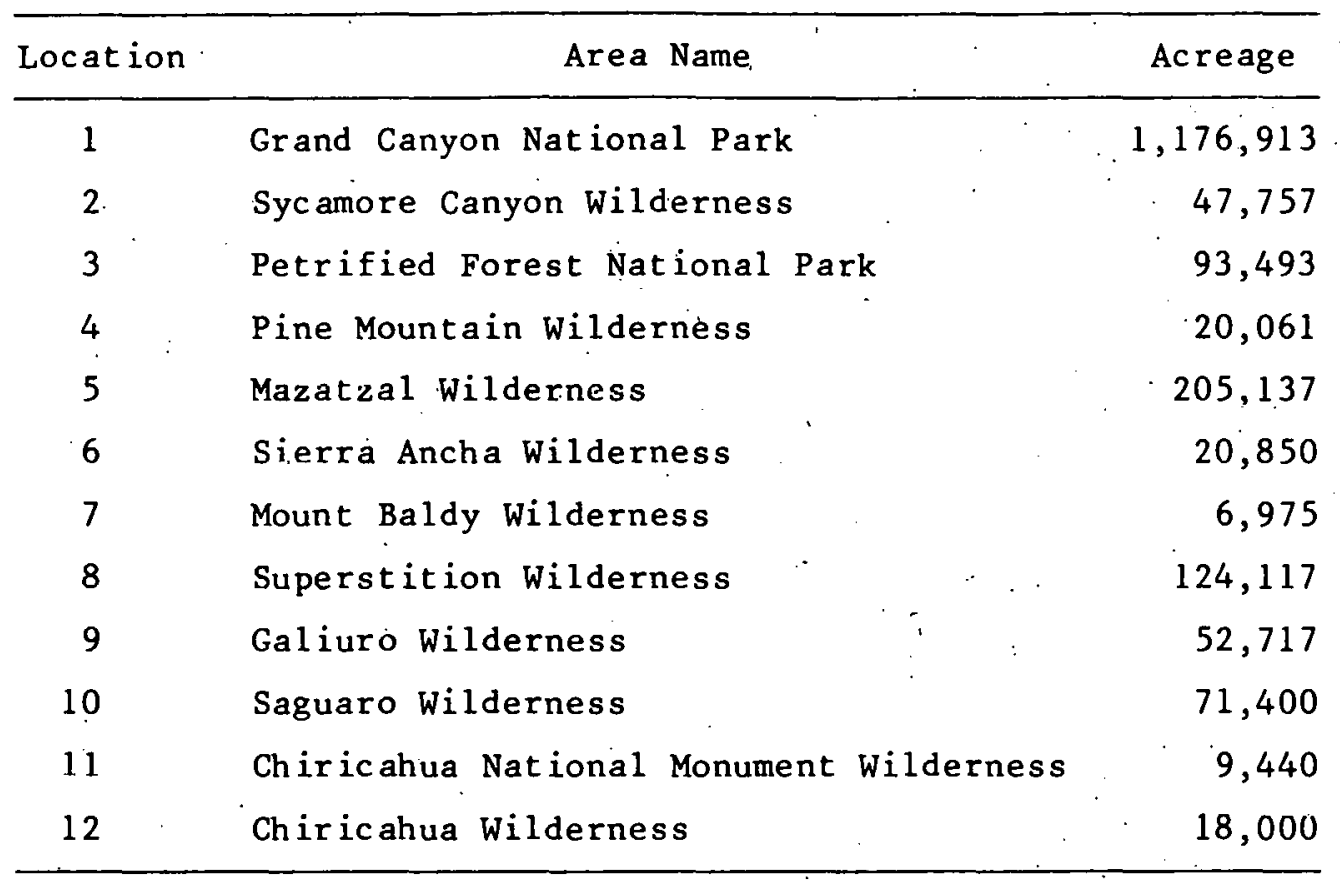




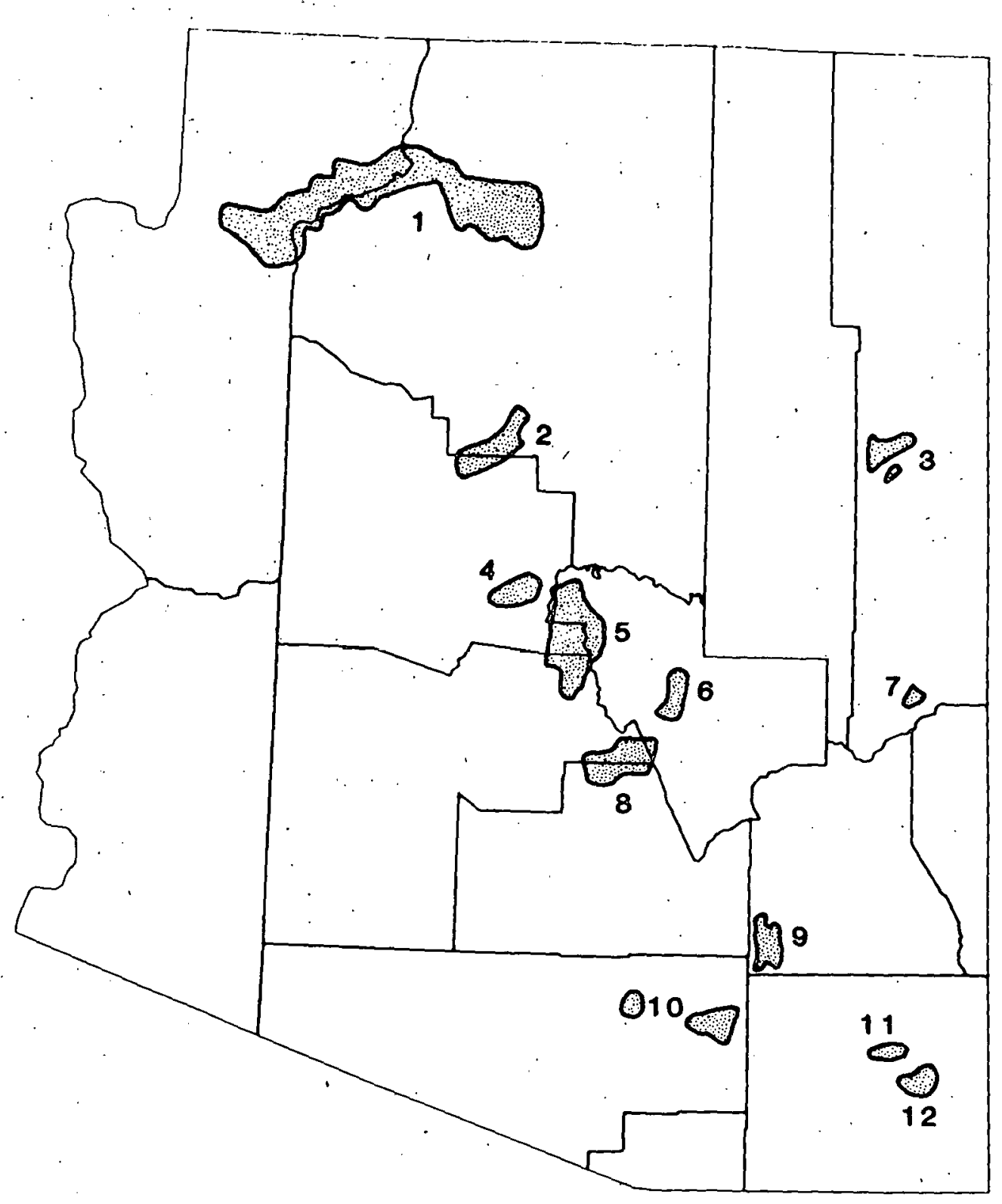

Fig. C.2 Arizona: PSD Class I Areas 
Table C.3 Arkansas: PSD Class I Areas

\begin{tabular}{ccr}
\hline Location & Area Name & Acreage \\
\hline 1 & Upper Buffalo Wilderness & 9,912 \\
2 & Caney Creek Wilderness & 14,344 \\
\hline
\end{tabular}




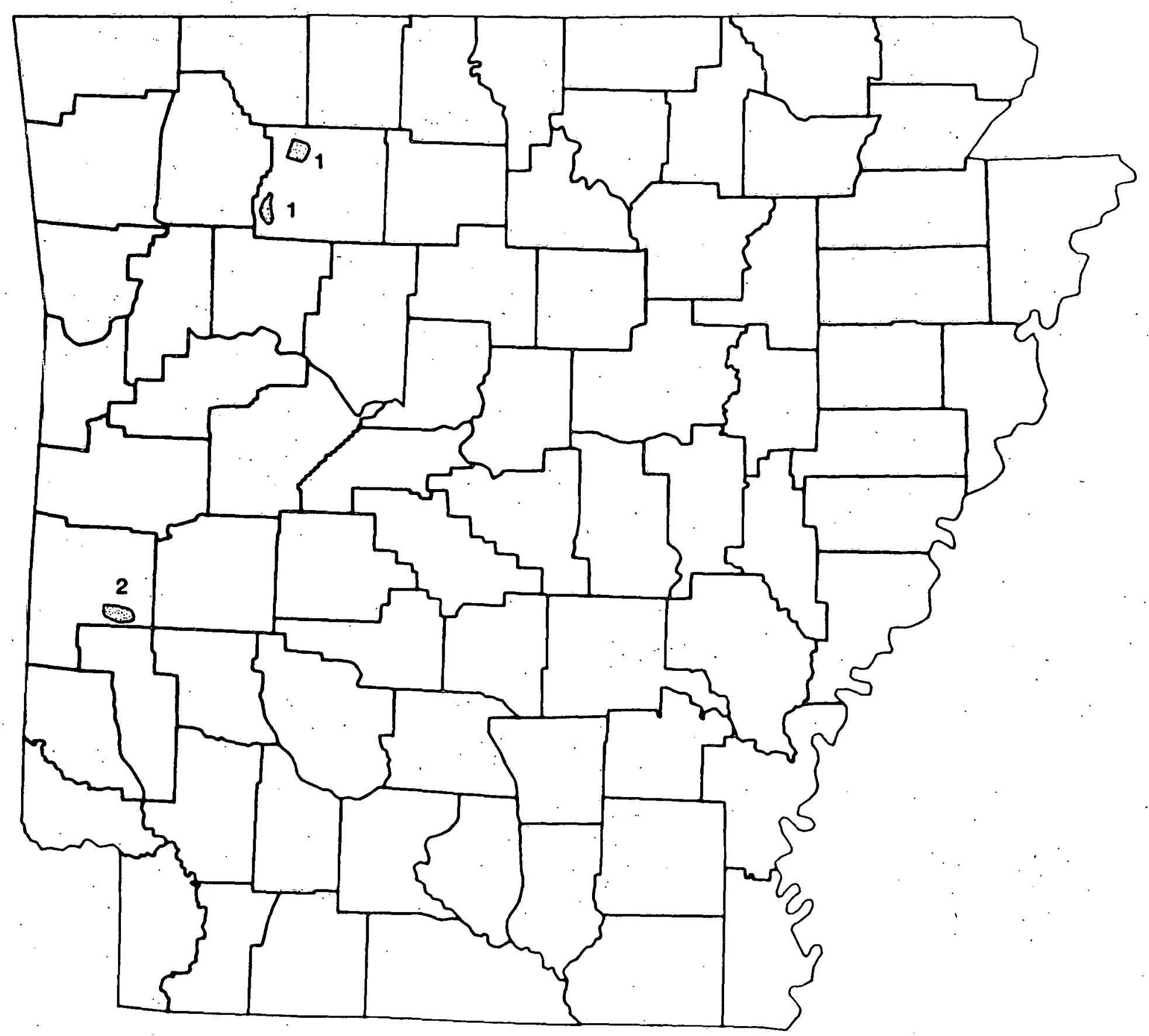

Fig. C.3 Arkansas: PSD Class I Areas 
Table C.4. California: PSD Class I Areas

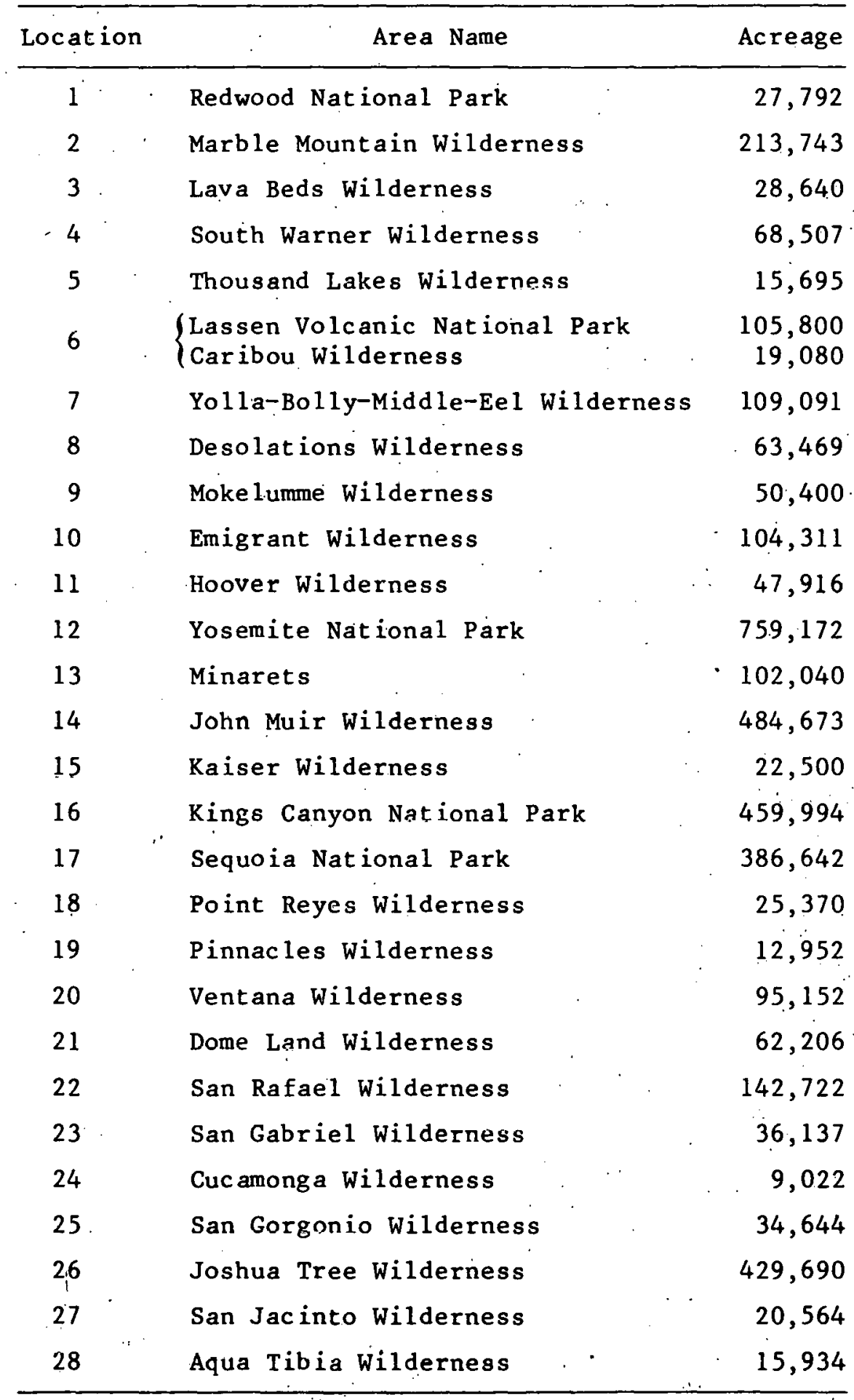




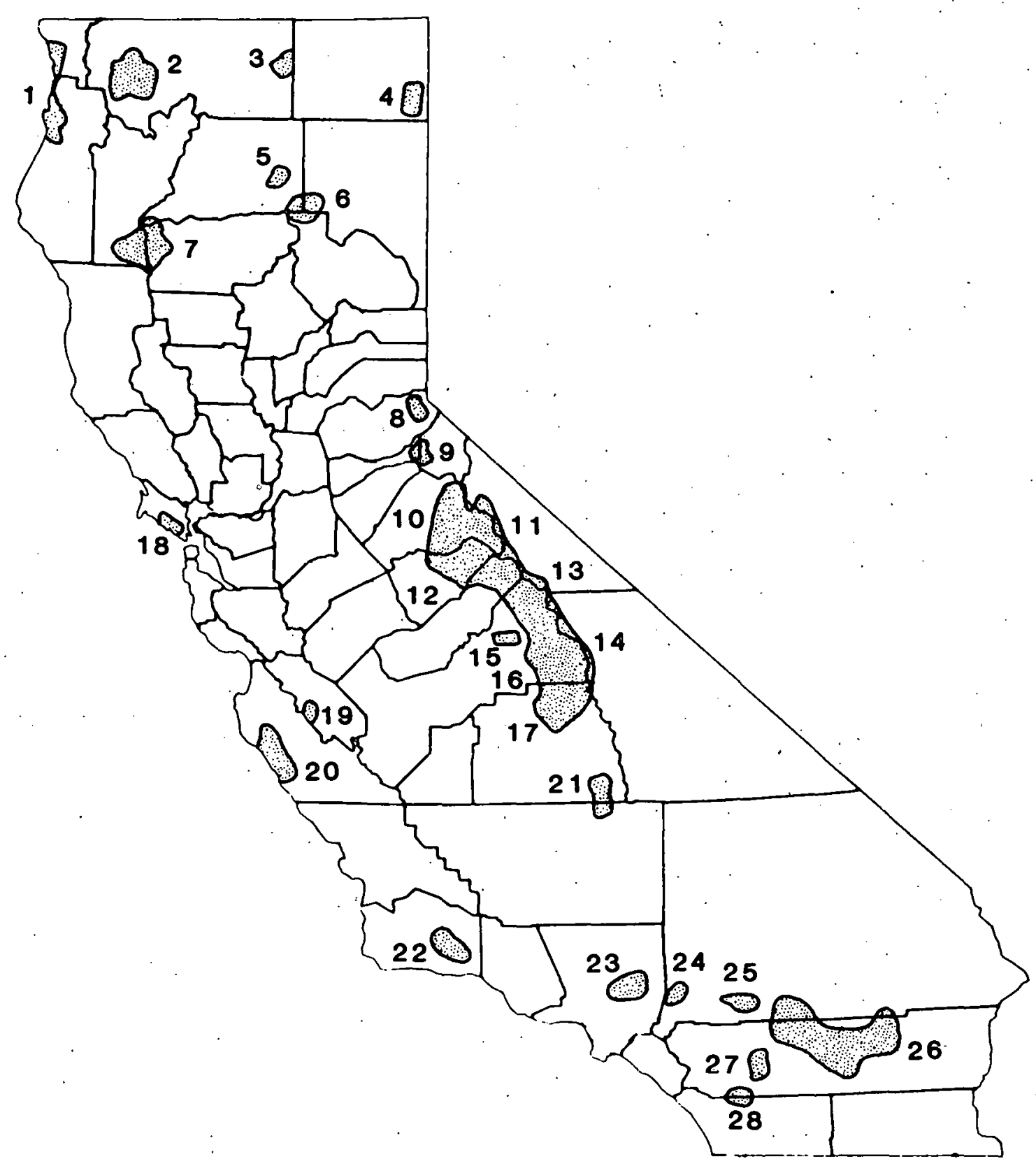

Fig. C.4 California: PSD Class I Areas 
Table C.5 Colorado: PSD Class. I Areas

\begin{tabular}{rlr}
\hline Location & \multicolumn{1}{c}{ Area Name } & Acreage \\
\hline 1 & Mount Zirkel Wilderness & 72,472 \\
2 & Rawah Wilderness & 26,674 \\
3 & Rocky Mountain National Park & 283,138 \\
4 & Flat Tops Wilderness & 235,230 \\
5 & Eagles Nest Wilderness & 133,910 \\
6 & Maroon-Bells-Snownass Wilderness & 71,060 \\
7 & West Elks Wilderncoo & $61,41.2$ \\
8 & Black Canyon of the Gunnison Wilderness & 11,180 \\
9 & La Garita Wilderness & 48,486 \\
10 & Weminuche Wilderness & 400,907 \\
11 & Great Sand Dunes Wilderness & 33,450 \\
12 & Mesa Verde National Park & 51,488 \\
\hline
\end{tabular}




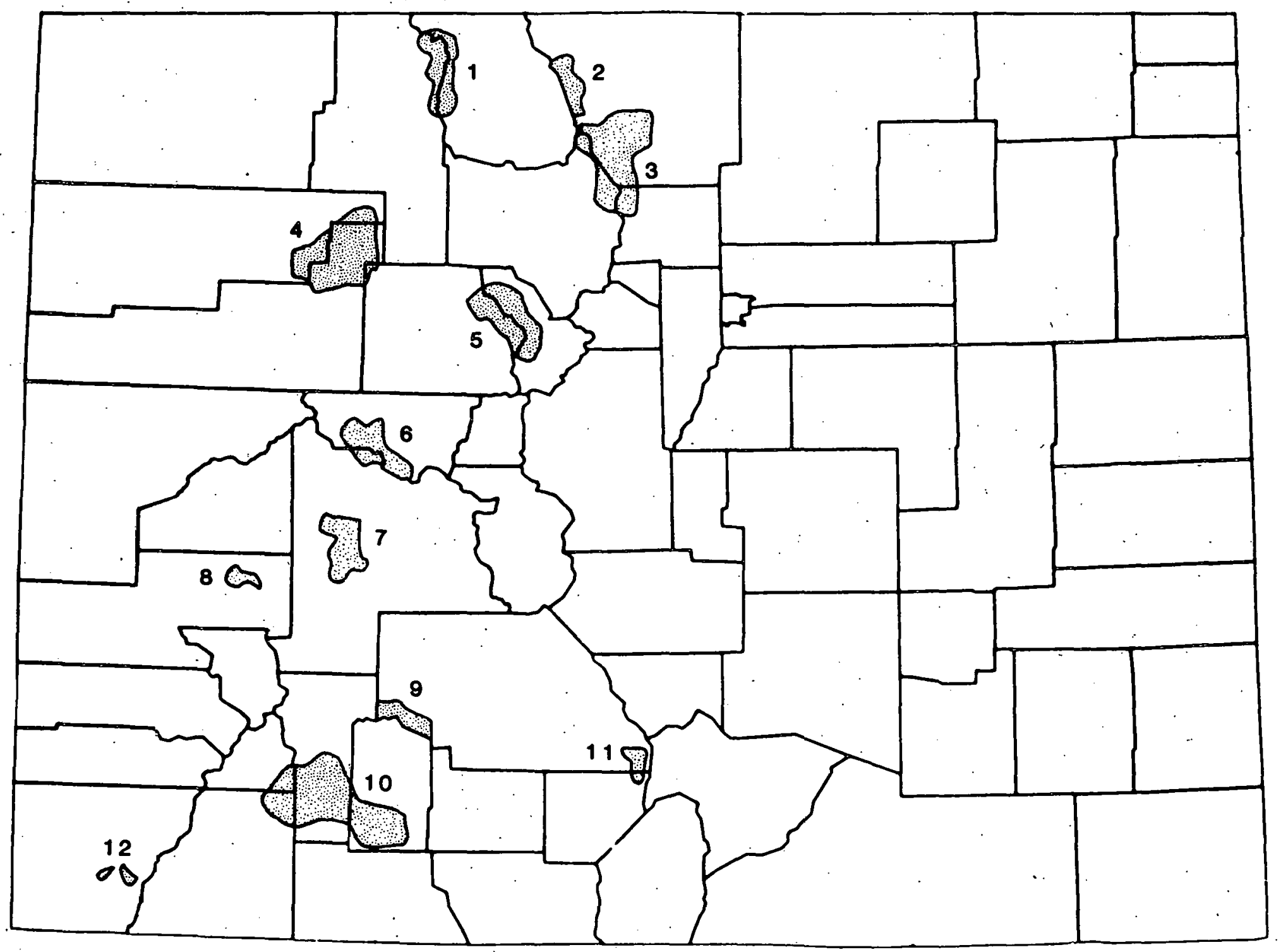


Table C.6" Florida: PSD Class I Areas

\begin{tabular}{clr}
\hline Location & \multicolumn{1}{c}{ Area Name } & \multicolumn{1}{c}{ Acreage } \\
\hline 1 & Bradwel1 Bay Wilderness & 22,000 \\
2 & St. Marks Wilderness & 17,745 \\
3 & Chassahowitzka Wilderness & 23,360 \\
4 & Everglades National Park & $1,397,429$ \\
\hline
\end{tabular}




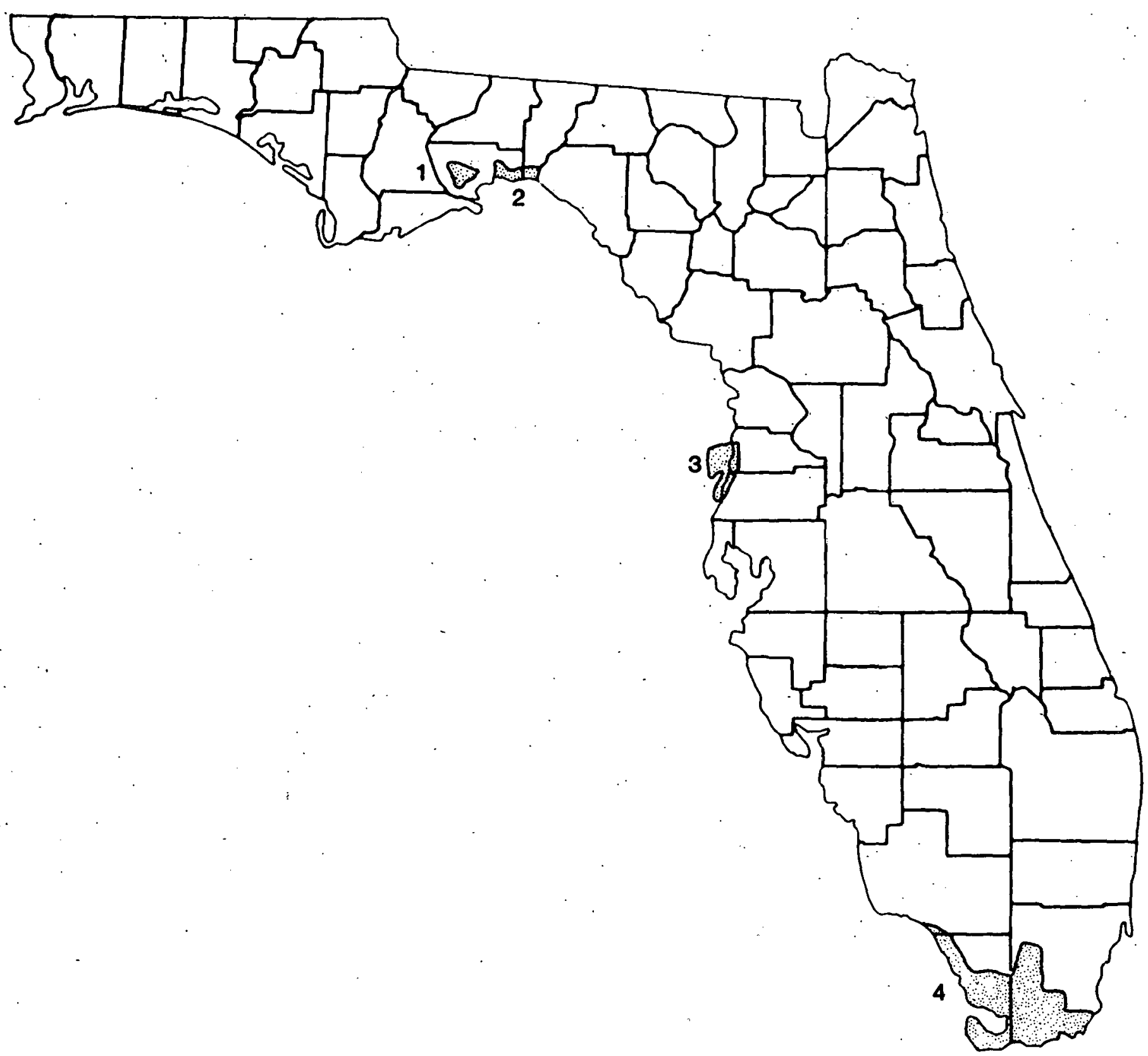

Fig. C.6 Florida: PSD Class I Areas 
196

Table. C.7 Georgia: PSD Class I Areas

\begin{tabular}{clr}
\hline Location & \multicolumn{1}{c}{ Area Name } & Acreage \\
\hline 1 & Cohotta Wilderness & 33,776 \\
2 & Wolf Island Wilderness & 5,126 \\
3 & Okefenokee Wilderness & 343,850 \\
\hline
\end{tabular}


197

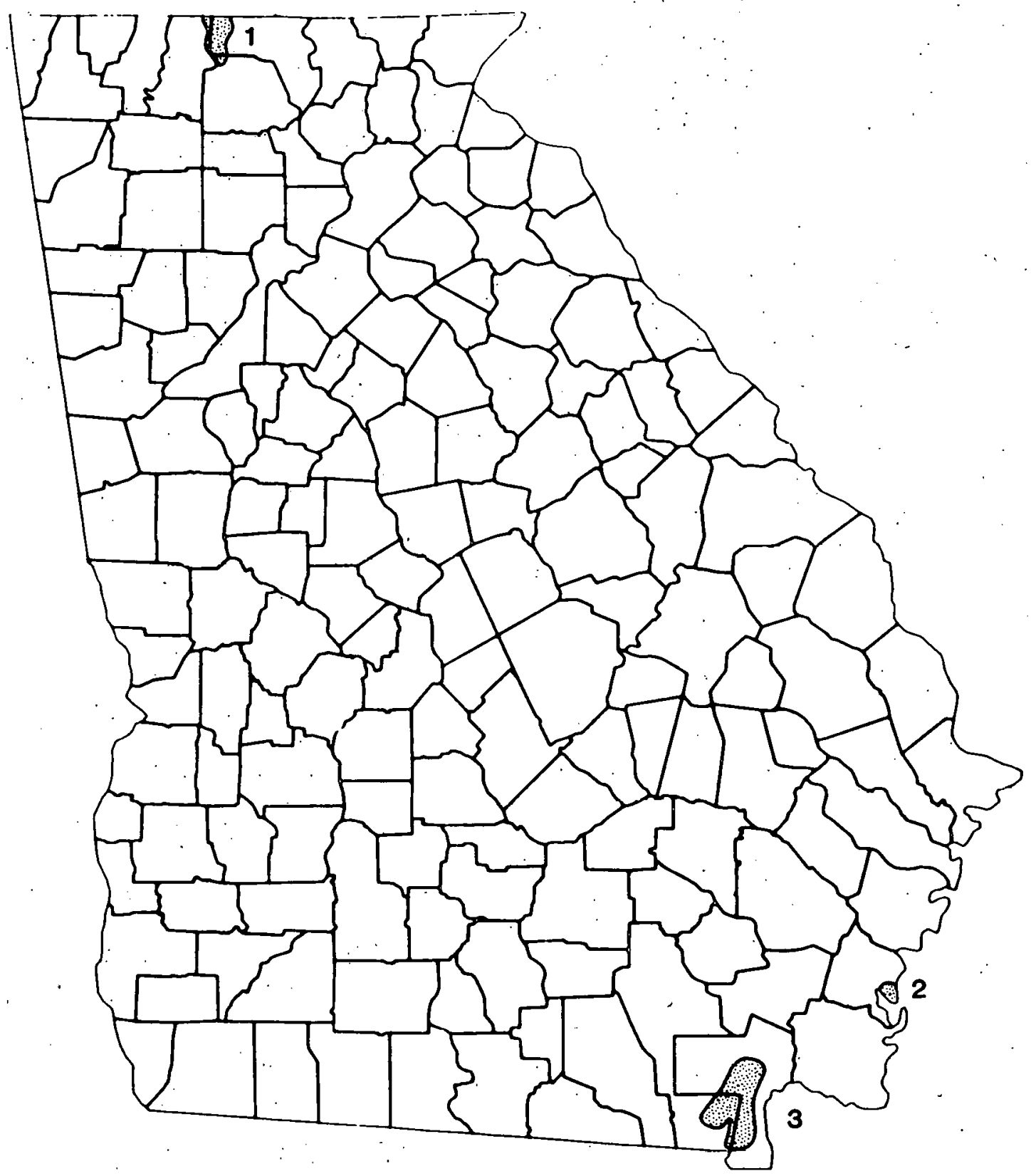

Fig. C.7 Georgia: PSD Class I Areas 
Table C.8: Idaho: PSD Class I Areas

\begin{tabular}{clc}
\hline Location & \multicolumn{1}{c}{ Area Name } & Acreage \\
\hline 1 & Selway-Bitterroot Wilderness & $983,417^{\mathrm{a}}$ \\
2 & Hells Canyon Wilderness & $83,800^{\mathrm{b}}$ \\
3 & Sawtooth Wilderness & 216,383 \\
4 & Craters of the Moon Wilderness & 43,243 \\
5 & Yellowstone National Park & $31,488^{\mathrm{c}}$ \\
\hline
\end{tabular}

aselway-Bitterroot Wilderness, 1,232,310 acres overall, includes an area in Montana.

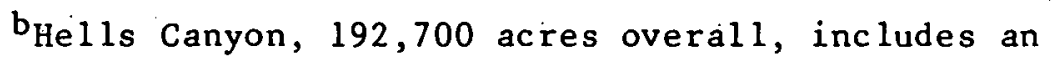
area in Oregon.

cyellowstone National Park, 2,219,737 acres overall, includes areas in Montana and Wyoming. 


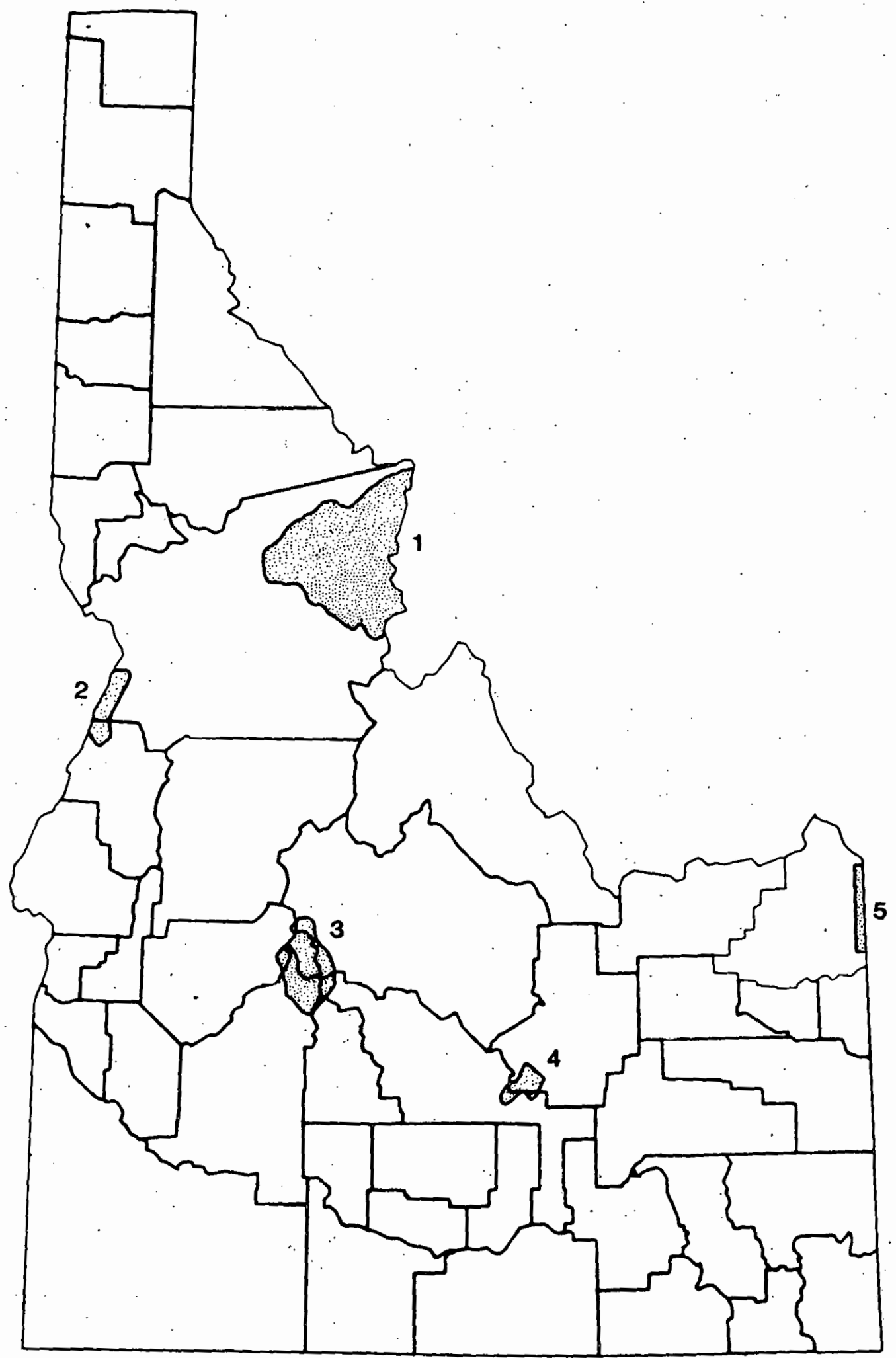

Fig. C.8 Idaho: PSD Class I Areas 
Table C.9 Kentucky: PSD Class I Area

\begin{tabular}{ccc}
\hline Location & Area Name & Acreage \\
\hline 1 & Mammoth Cave & 51,303 \\
\hline
\end{tabular}




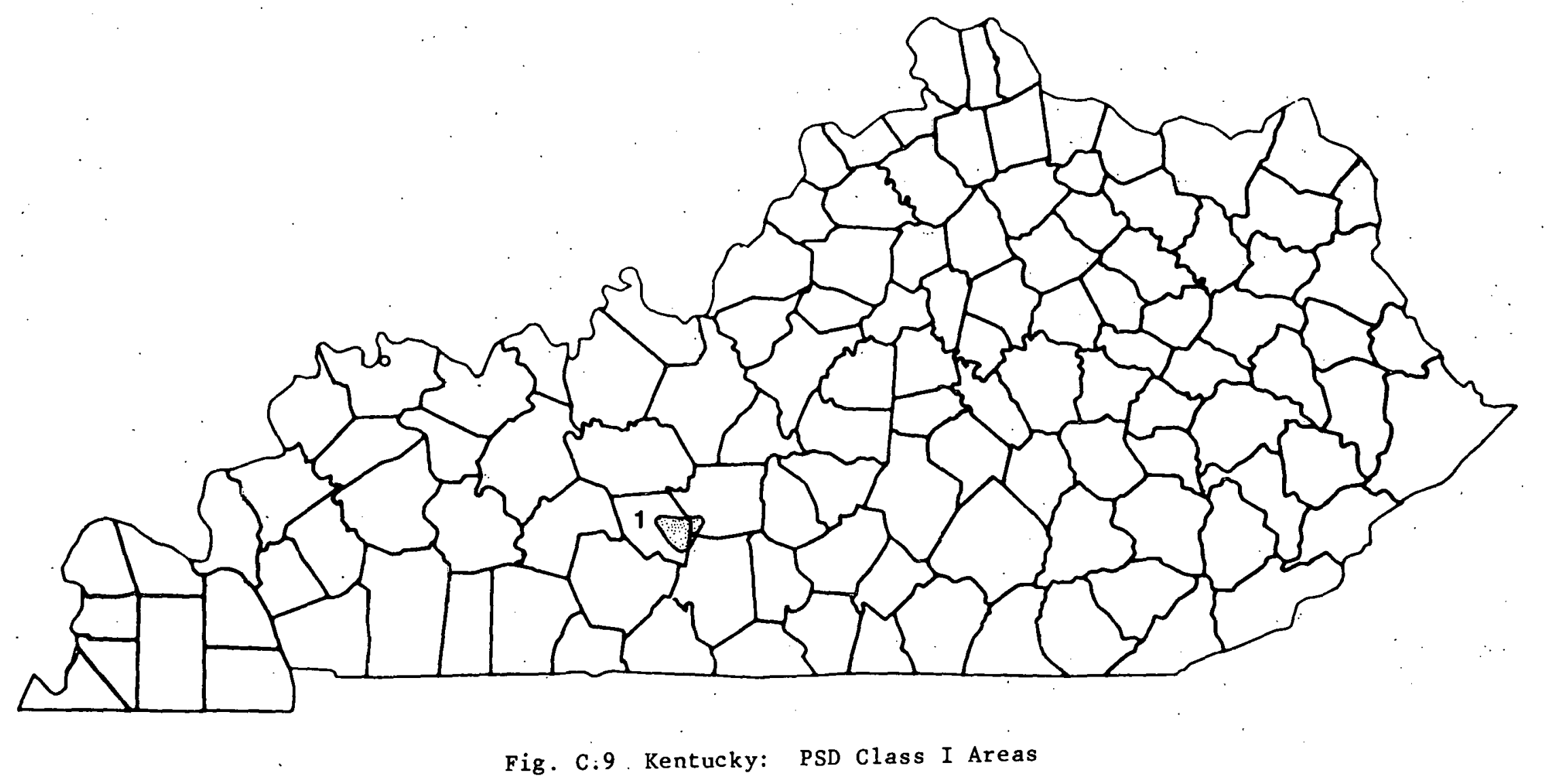


Table C.10 Louisiana: PSD Class I Area

\begin{tabular}{ccc}
\hline Location & Area Name & Acreage \\
\hline 1 & Breton Wilderness & $5,000+$
\end{tabular}




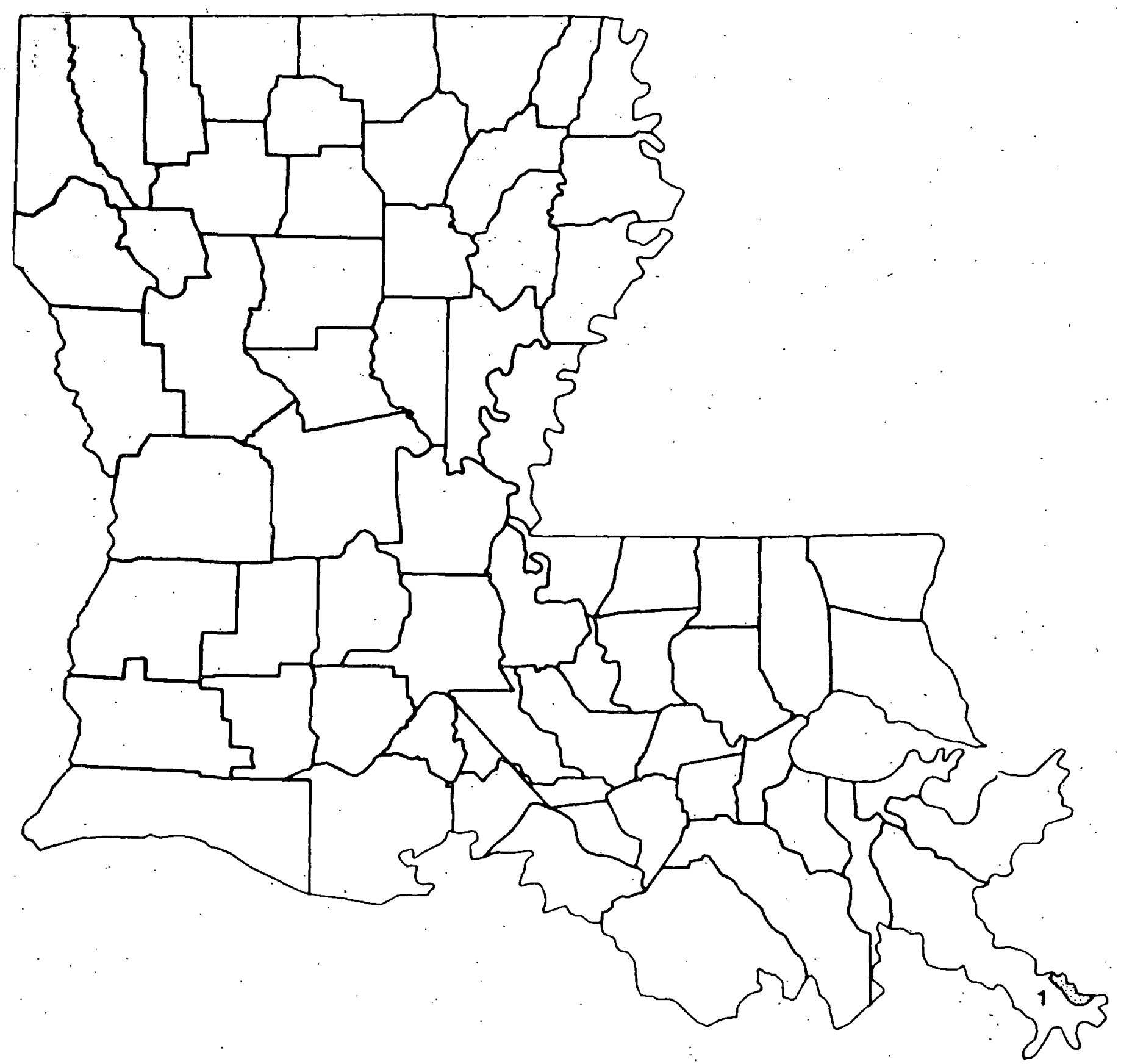

ڤั

Fig. C.10 Louisiana: PSD Class I Area 
Table C.1l Maine: PSD Class I Areas

\begin{tabular}{ccc}
\hline Location & Area Name & Acreage \\
\hline 1 & Moosehorn Wilderness & 7,501 \\
2 & Acadia Nat ional Park & 37,503 \\
\hline
\end{tabular}


205

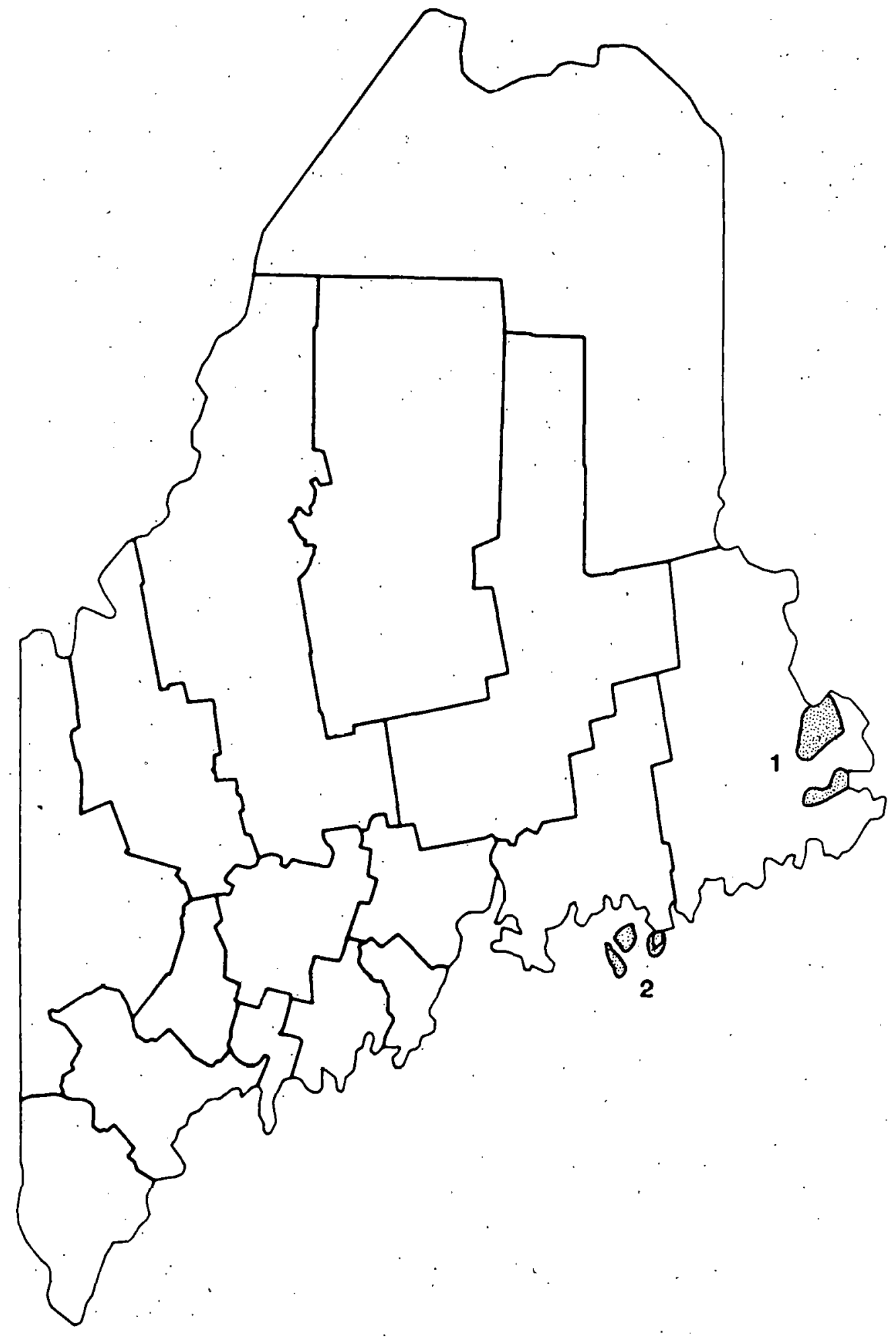

Fig. C.11 Maine: PSD Class I Areas 
Table C.12 Michigan: PSD Class I Areas

\begin{tabular}{clr}
\hline Location & \multicolumn{1}{c}{ Area Name } & Acreage \\
\hline 1 & Isle Royale National Park & 542,428 \\
2 & Seney Wilderness & 25,150
\end{tabular}




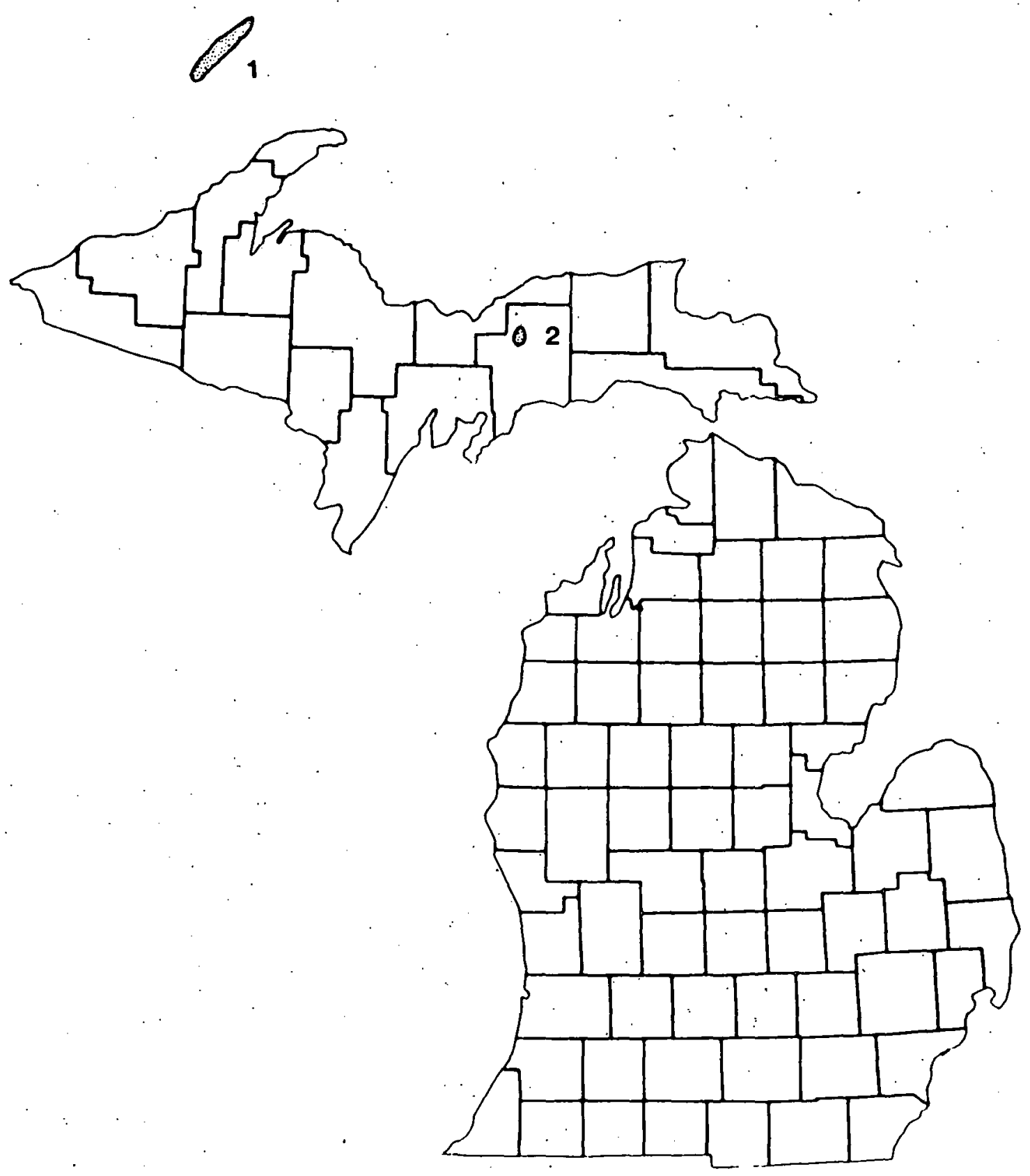

Fig. C.12 Michigan: PSD Class I Areas 
208

Table C.13 Minnesota: PSD Class I Areas

\begin{tabular}{cccc}
\hline Location & \multicolumn{1}{c}{ Area Name } & Acreage \\
\hline 1 & & Voyageurs National Park & 114,964 \\
2 & $\cdots$ & Boundary Waters Canoe Area Wilderness & 747,840 \\
\hline
\end{tabular}




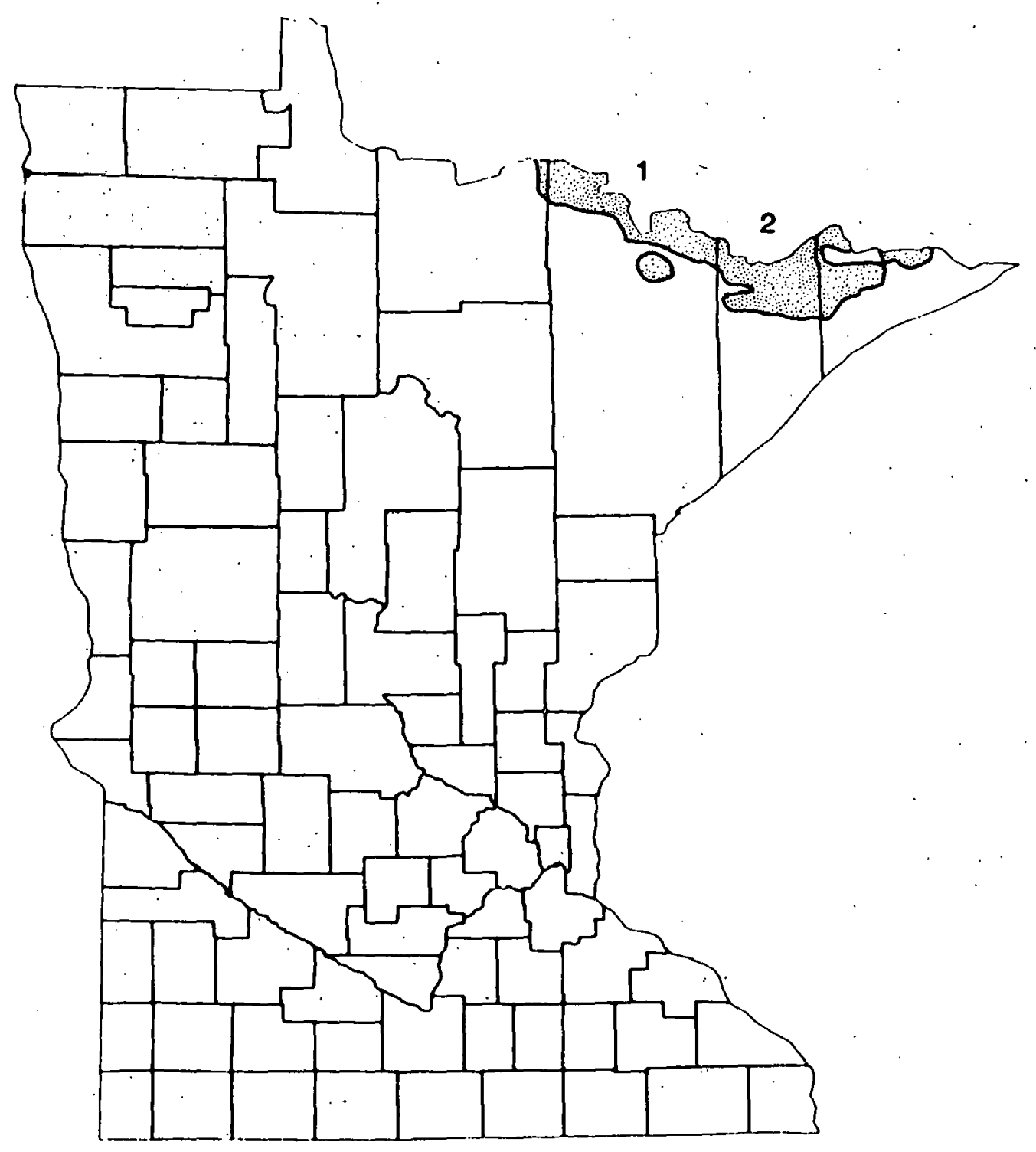

Fig. C.13 Minnesota: PSD Class I Areas 
Table C.14 Missouri: PSD Class I Areas

\begin{tabular}{clr}
\hline Location & \multicolumn{1}{c}{ Area Name } & Acreage \\
\hline 1 & Mingo Wilderness & 8,000 \\
2 & Hercules-Glades Wilderness & 12,315 \\
\hline
\end{tabular}




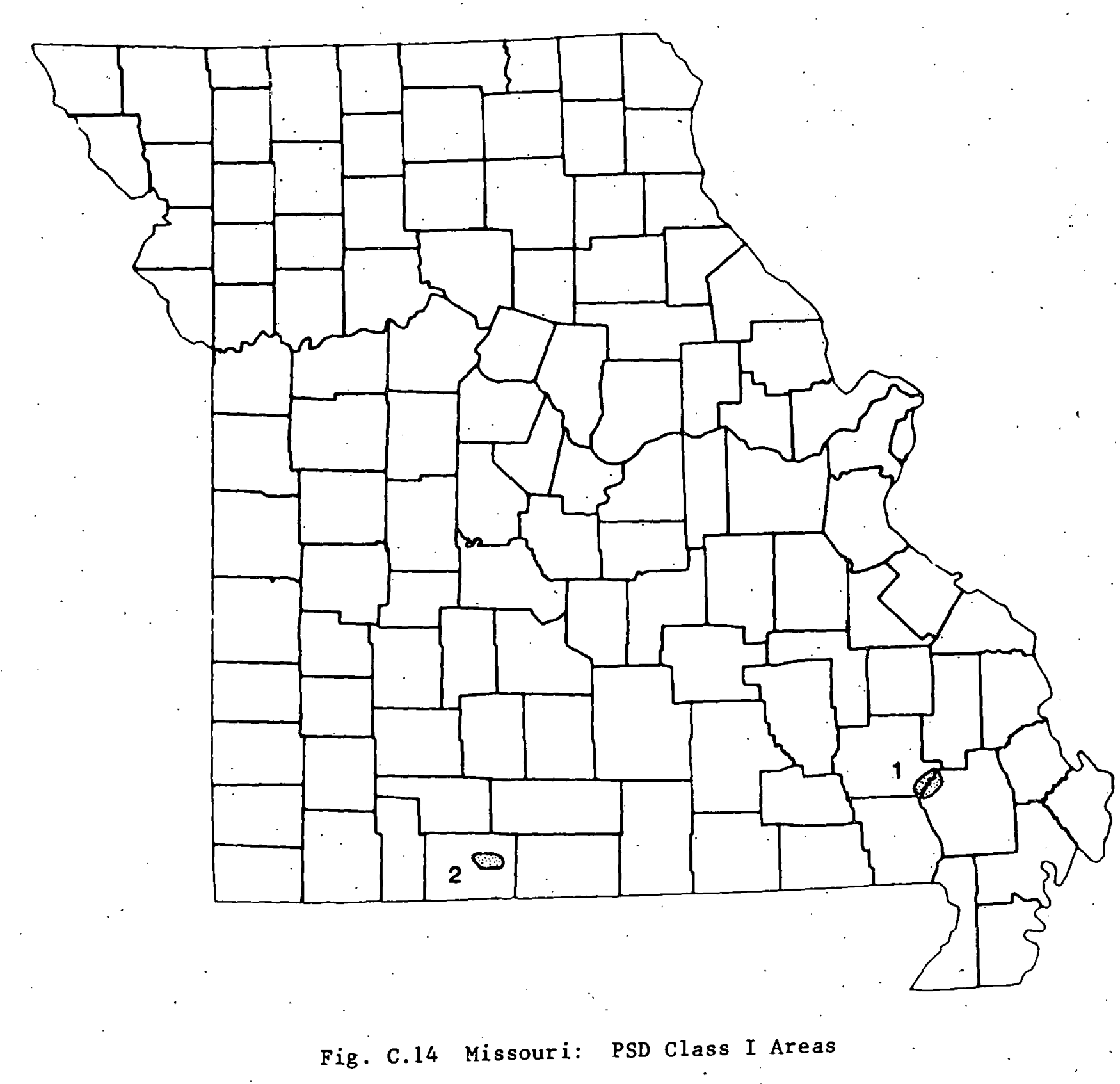


Table C.15 Montana: PSD Class I Areas

\begin{tabular}{clr}
\hline Location & \multicolumn{1}{c}{ Area Name } & Acreage \\
\hline 1 & Glacier National Park. & $1,012,599$ \\
2 & Cabinet Mountains Wilderness & 94,272 \\
3 & Bob Marshall Wilderness & 950,000 \\
4 & U.L : Bend Wilderness & 20,890 \\
5 & Medicine Lake Wilderness & 11,366 \\
6 & Mission Mountain Wildernes's & 73,877 \\
7 & Scapogoat wilderness & 239,295 \\
8 & Gates of the Mountain Wilderness & 28,562 \\
9 & Anaconda-Pintlar Wilderness & 157,803 \\
10 & Red Rock Lakes Wilderness & 32,350 \\
11 & Yellowstone National Park & $167,624^{a}$ \\
12 & Northern Cheyenne Reservationb & 444,157 \\
\hline
\end{tabular}

aYel lows tone National Park, 2,219,737 acres overall, includes areas in Idaho and Wyoming.

bNorthern Cheyenne Reservation has been redesignated Slass I; it was not a mandatory Class I area. 


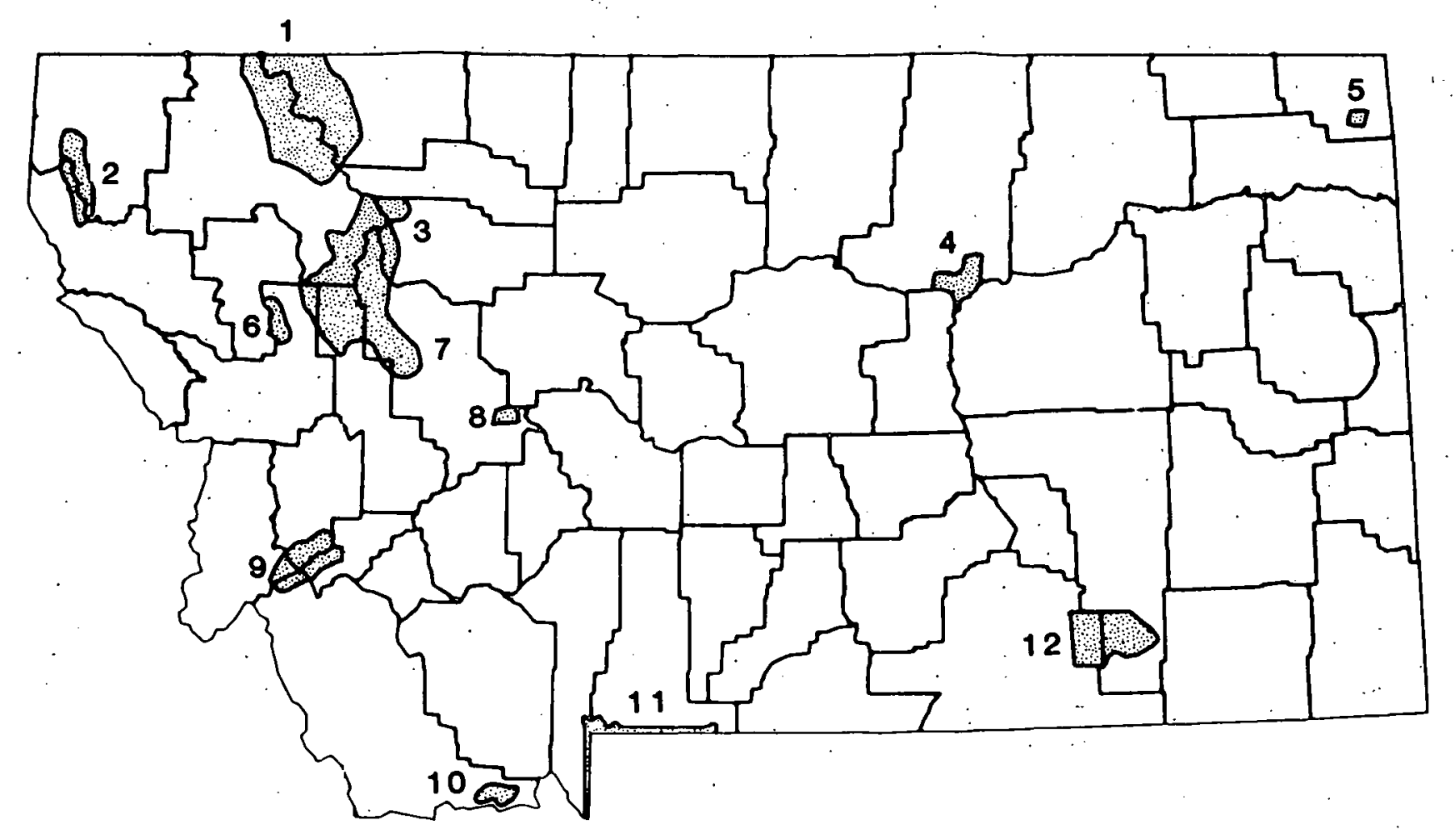

Fig. C.15. Montana: PSD Class I Areas 
214

Table C.16 Nevada: PSD Class I Area

\begin{tabular}{cccc}
\hline Location & Area Name & Acreage \\
\hline 1 & Jarbidge Wilderness & 64,667 \\
\hline
\end{tabular}




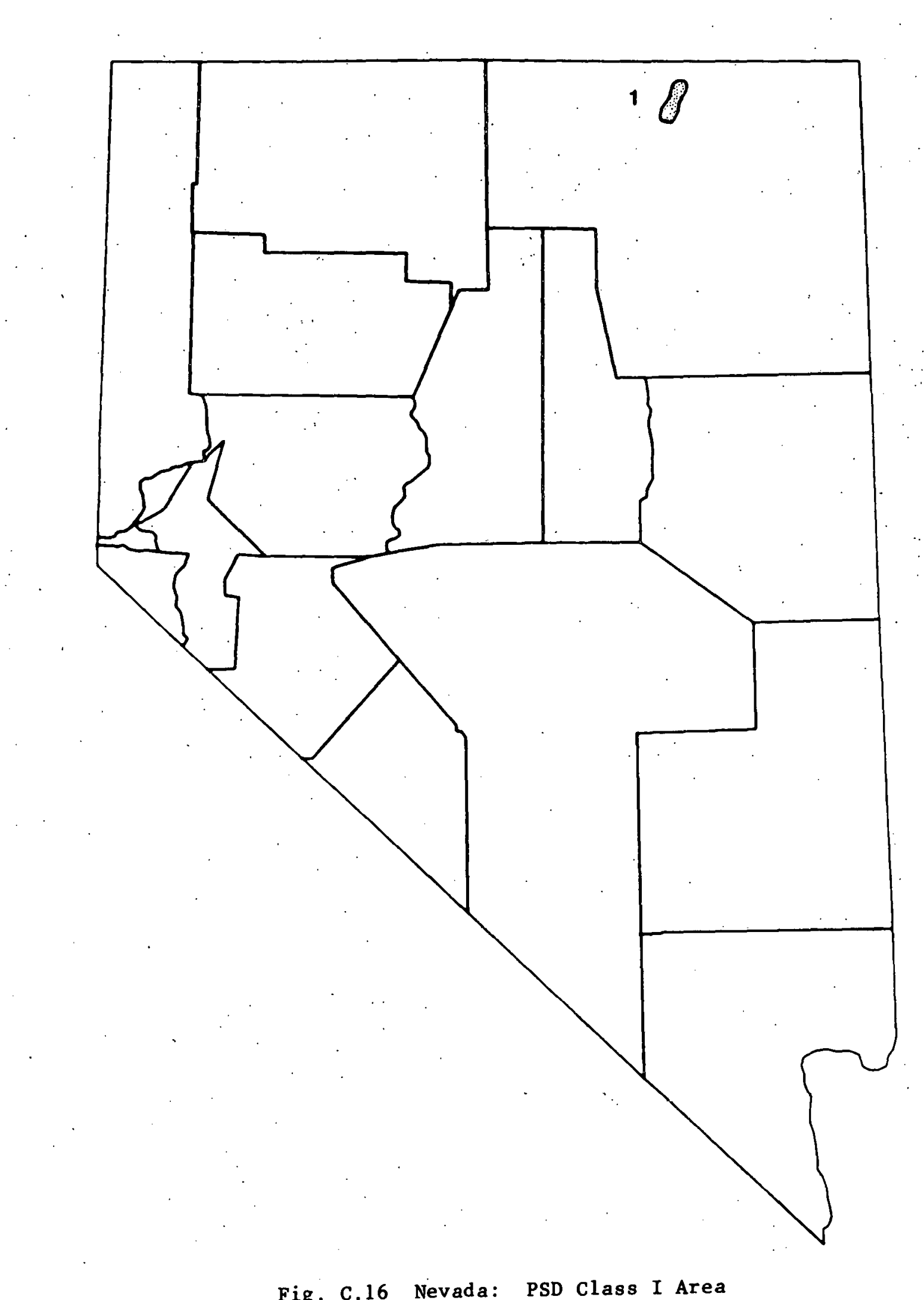


Table C.17 New Hampshire: PSD Class I Areas

\begin{tabular}{clr}
\hline Location & \multicolumn{1}{c}{ Area Name } & Acreage \\
\hline 1 & Great Gulf Wilderness & 5,552 \\
2 & Presidential Range - Dry River Wilderness & 20,000
\end{tabular}


217

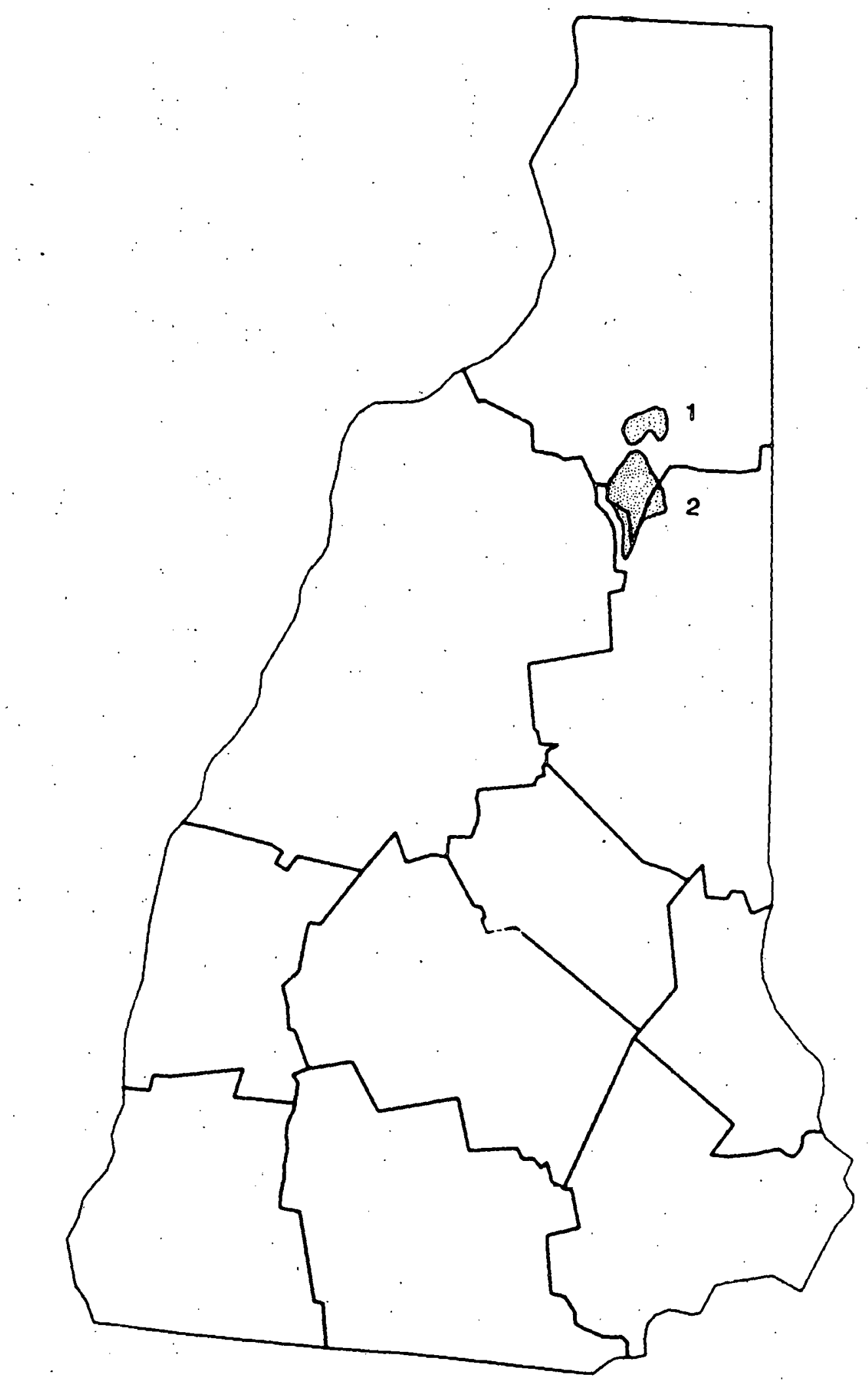

Fig. C.17 New Hampshire: PSD Class I Areas 
Table C.18 New Jersey: PSD Class I Area

\begin{tabular}{ccc}
\hline Location & Area Name & Acreage \\
\hline 1 & Brigantine Wilderness & 6,603 \\
\hline
\end{tabular}




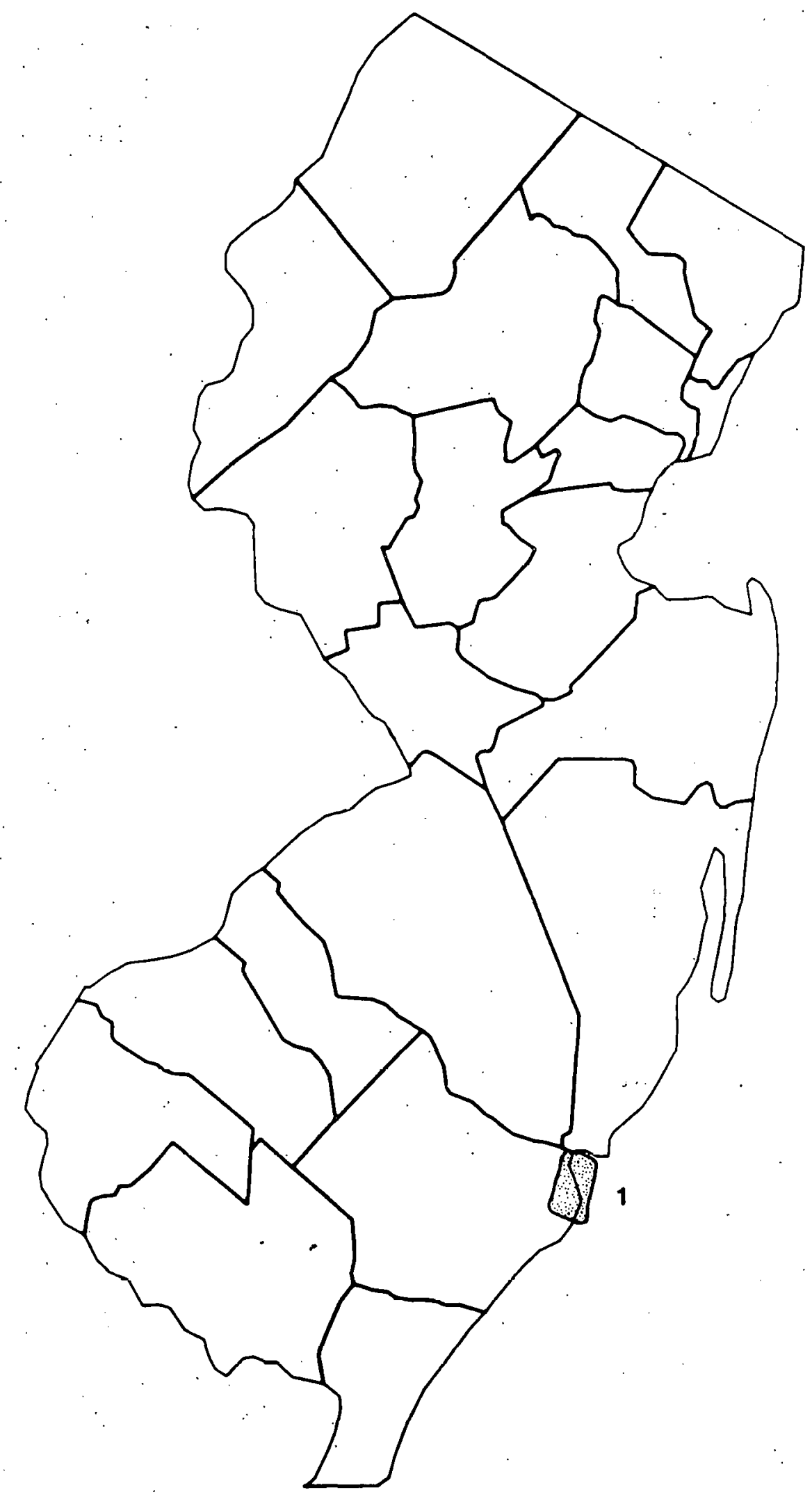

Fig. C.18 New Jersey: PSD Class I Area 
Table C.19 New Mexico: PSD Class I Areas

\begin{tabular}{|c|c|c|}
\hline Location & Area Name & Acreage \\
\hline 1 & San Pedro Parks Wilderness & 41,132 \\
\hline 2 & Wheeler Peak Wilderness & 6,027 \\
\hline 3 & Bandelier Wilderness & 23,267 \\
\hline 4 & Pecos Wilderness & 167,416 \\
\hline 5 & Bosque del Apache Wilderness & 60,850 \\
\hline 6 & White Mountain Wilderness & 31,171 \\
\hline 7 & Ealt Crook Wildorness & 8,500 \\
\hline 8 & Gila Wilderness & 433,690 \\
\hline 9 & Carlsbad Caverns National Park & 46,435 \\
\hline
\end{tabular}




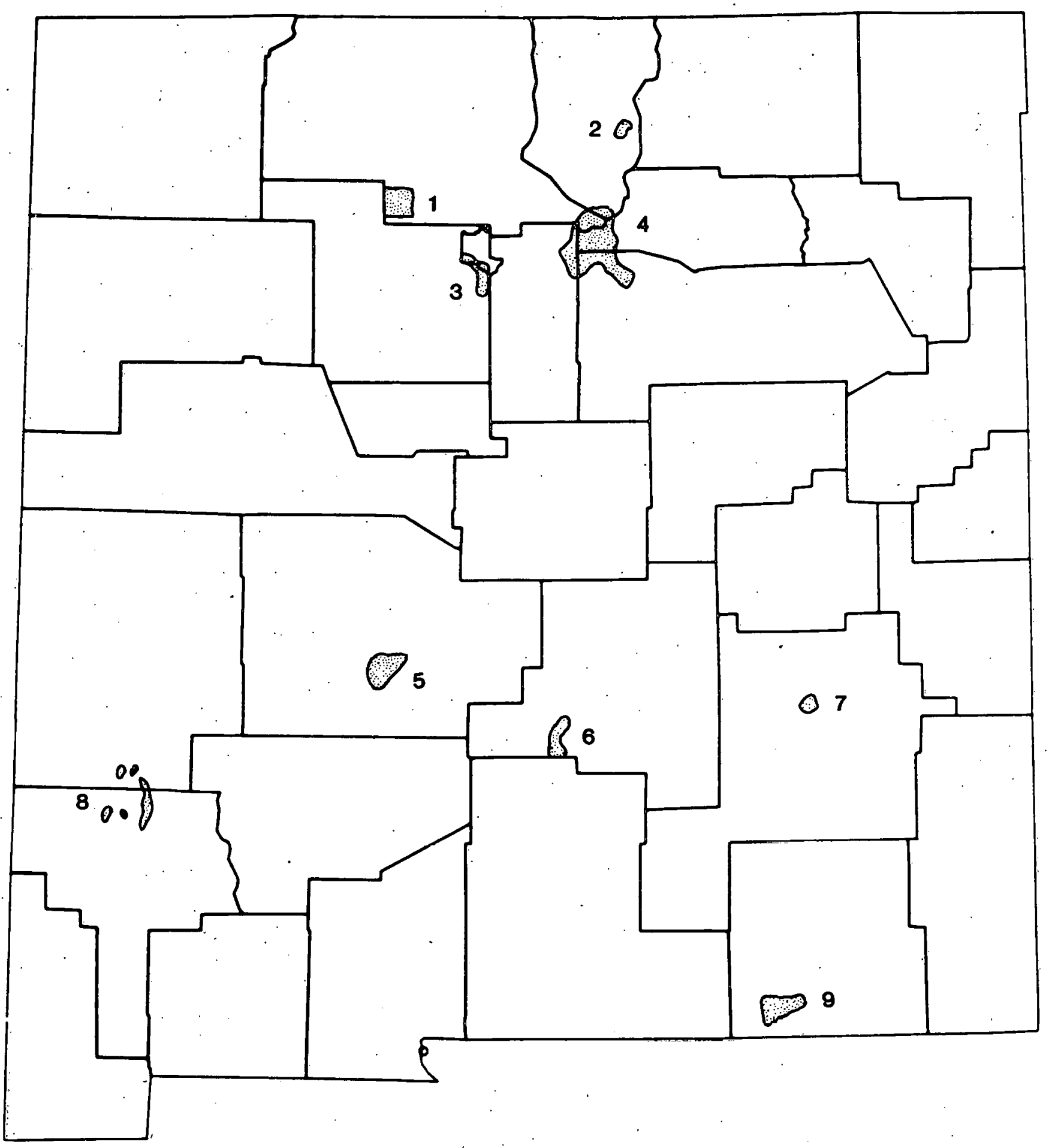

Fig. C.19 New Mexico: PSD Class I Areas 
Table C. 20 North Carolina: PSD Class I Areas

\begin{tabular}{clr}
\hline Location & \multicolumn{1}{c}{ Area Name } & Acreage \\
\hline 1 & Joyce-Kilmer-Slickrock Wilderness & $10,201^{\mathrm{a}}$ \\
2 & Great Smokey Mountains National Park & $273,551^{\mathrm{b}}$ \\
3 & Linville Gorge Wilderness & 7,575 \\
4 & Shining Rock Wilderness & 13,350 \\
5 & Swanquarter Wilderness & 9,000 \\
\hline
\end{tabular}

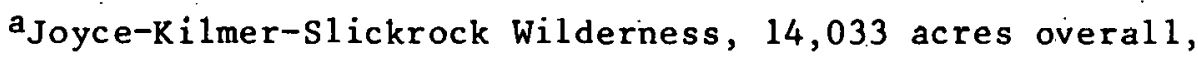
includes an area in Tennessee.

${ }^{b}$ Great Smokey Mountains National Park, 514,758 acres overall, includes an area in Tennessee. 


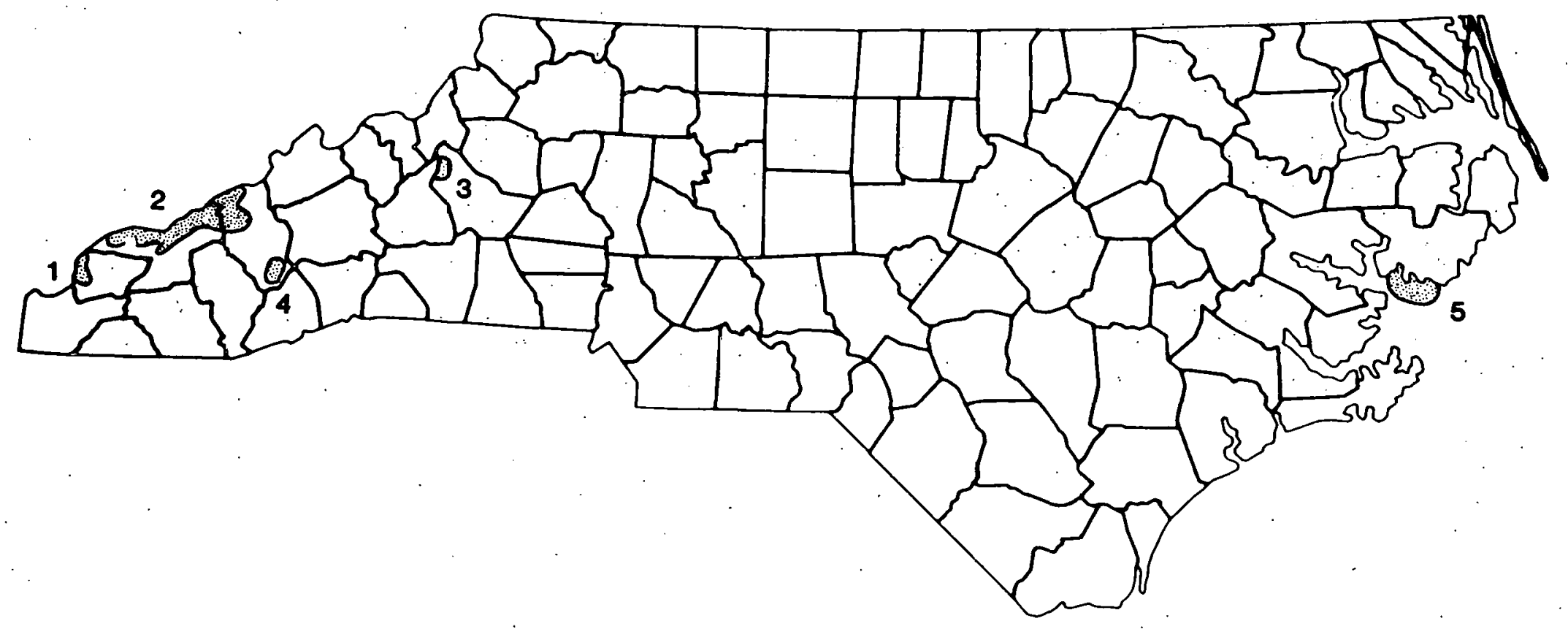

Fig. C.20 North Carolina: PSD Class I Areas 
Table C.21 North Dakota: PSD C.lass I Areas

\begin{tabular}{clr}
\hline Location & \multicolumn{1}{c}{ Area Name } & Acreage \\
\hline $1 \ldots$ & Lostwood Wilderness & 5,557 \\
2 & Theodore Roosevelt National Park & 69,675 \\
\hline
\end{tabular}




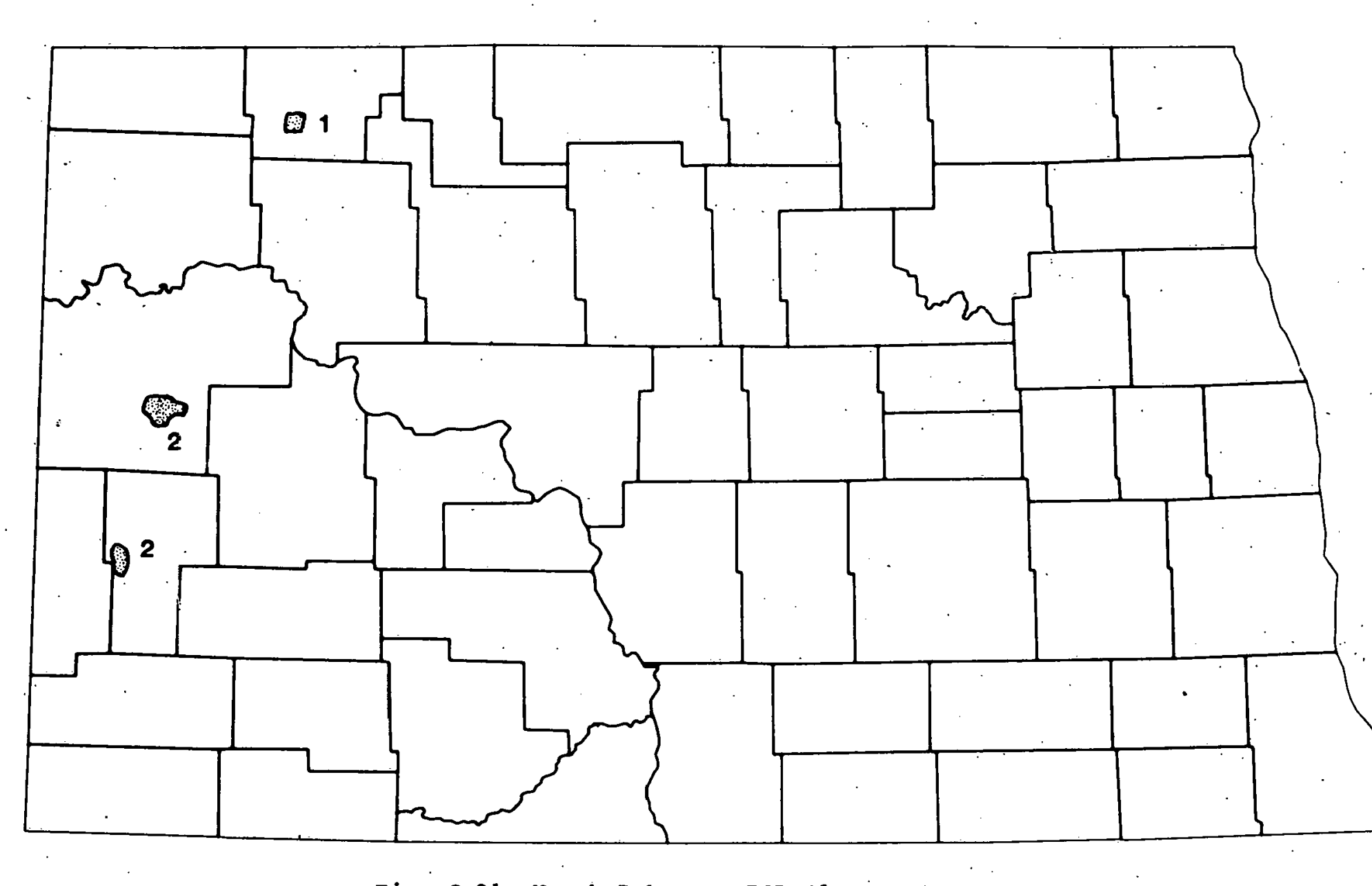


Table C.22 Oklahoma: PSD. Class I Area

\begin{tabular}{ccc}
\hline Location & Area Name & Acreage \\
\hline 1 & Wichita Mountains Wilderness & 8,900 \\
\hline
\end{tabular}




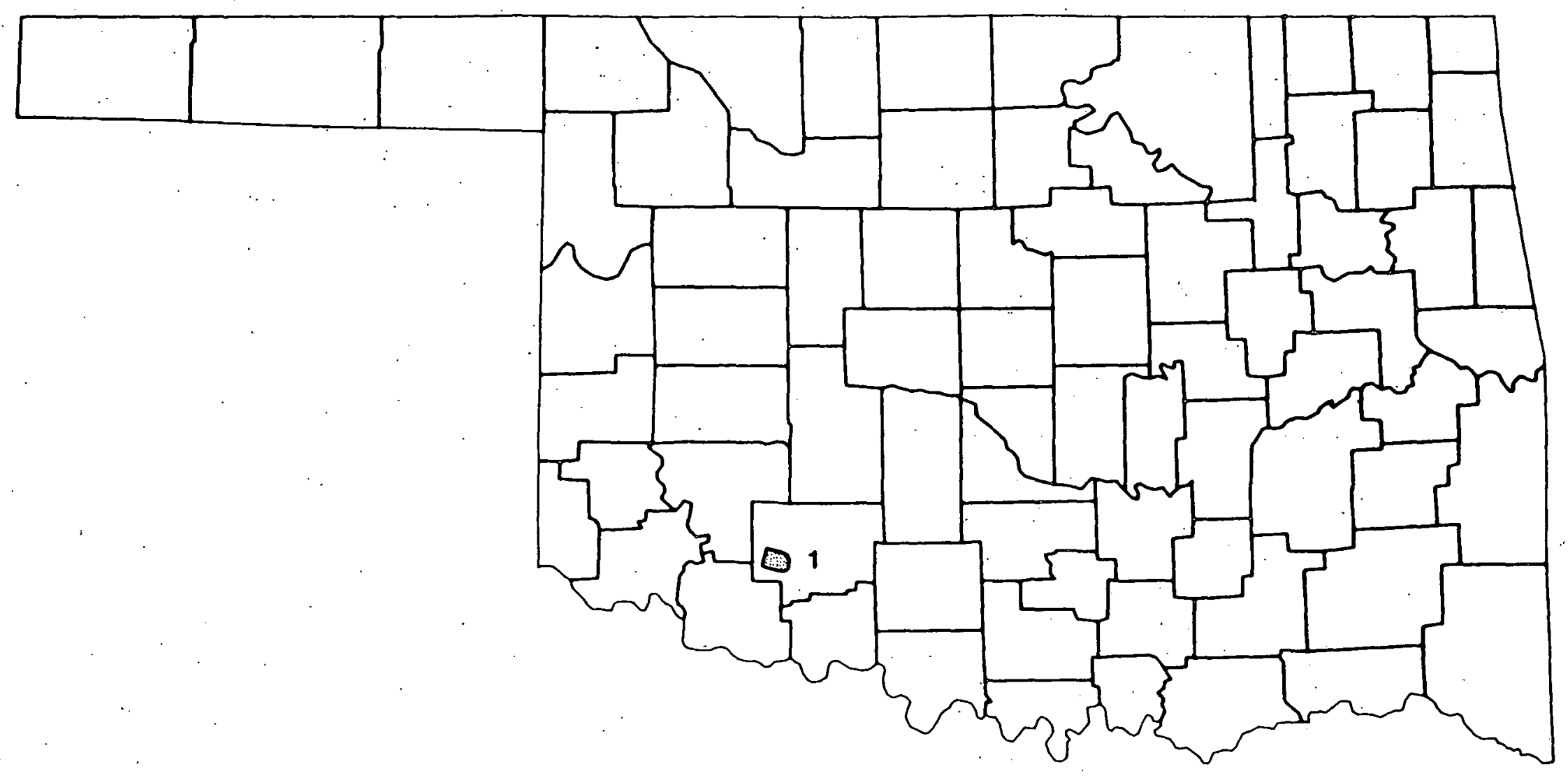

Fig. C.22 Oklahoma: PSD Class I Area 
Table C.23 Oregon: PSD Class I Areas

\begin{tabular}{clc}
\hline Location & \multicolumn{1}{c}{ Area Name } & Acreage \\
\hline 1 & Mount Hood Wilderness & 14,160 \\
2 & Hells Canyon & $108,900^{\mathrm{a}}$ \\
3 & Eagle Cap Wilderness & 293,476 \\
4 & Mount Jefferson Wilderness & 100,208 \\
5 & Mount Washington & 46,116 \\
6 & Three Sisters Wilderness & 199,902 \\
7 & Strawberry Mountain Wilderness & 33,003 \\
8 & Diamond Peak Wilderness & 36,637 \\
9 & Crater Lake National Park & 160,290 \\
10 & Kalmiopsis & 76,900 \\
11 & Mountain Lakes Wilderness & 23,071 \\
12 & Gearhart Mountain Wilderness & 18,709 \\
\hline
\end{tabular}

${ }^{a}$ Hells Canyon, 192,700 acres overall, includes an area in Idaho. 


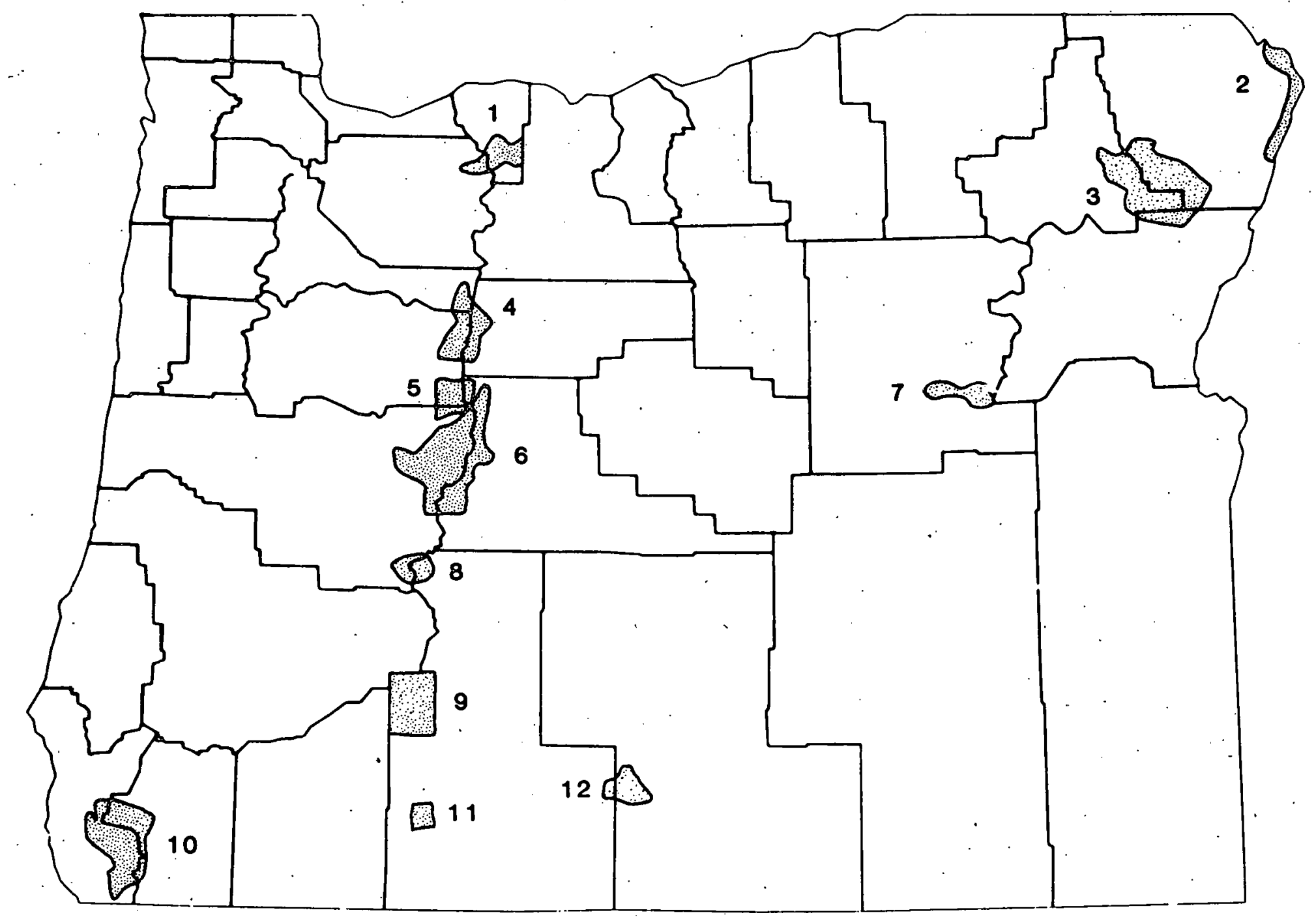

Fig. C.23 Oregon: PSD Class I Areas 
Table C.24 South Carolina: PSD Class I Area

\begin{tabular}{cccc}
\hline Location & Area Name & Acreage \\
\hline 1 & Cape Romain Wilderness & 28,000 \\
\hline
\end{tabular}




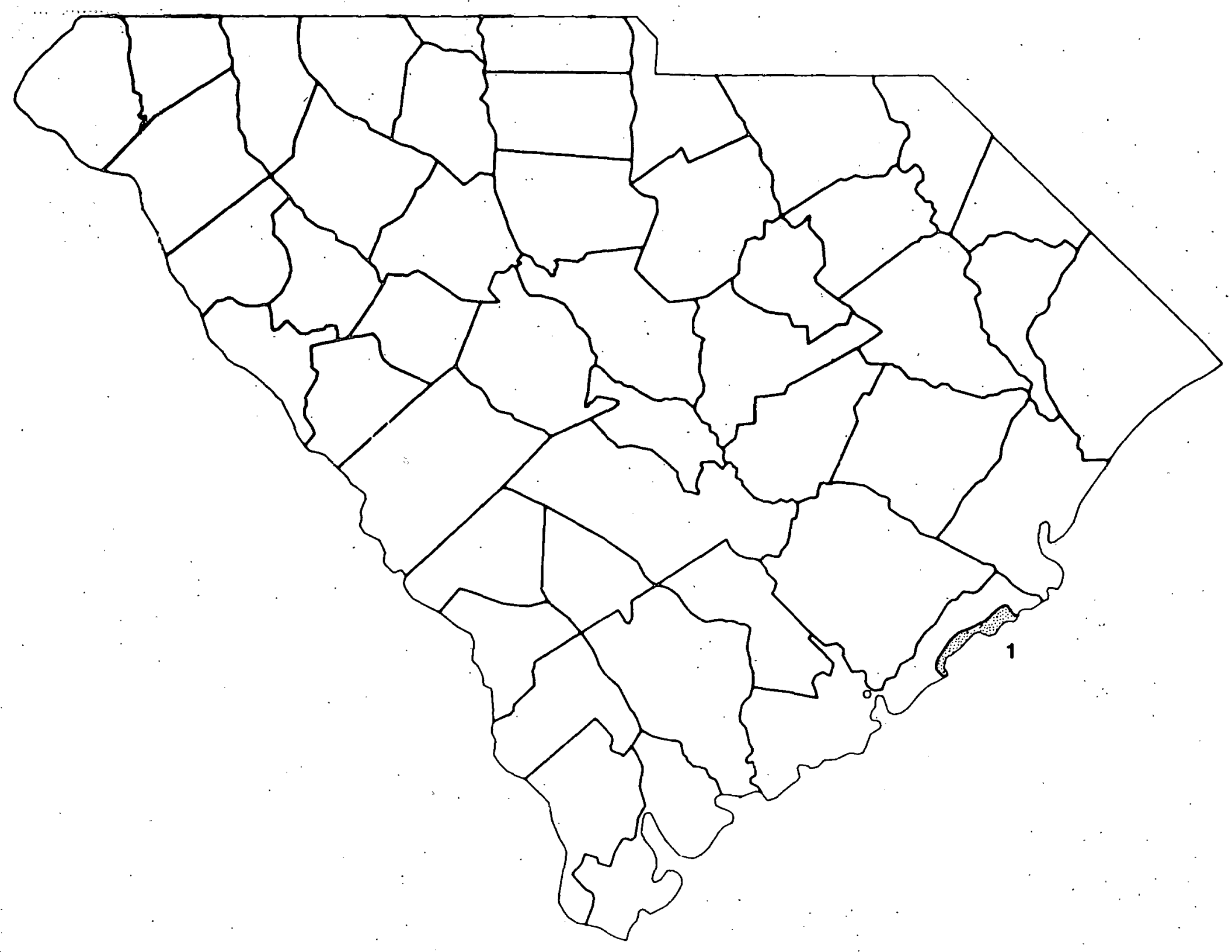

Fig. C.24 South Carolina: PSD Class I Areas 
Table C.25 South Dakota: PSD Class. I Areas

\begin{tabular}{clr}
\hline Location & \multicolumn{1}{c}{ Area Name } & Acreage \\
\hline 1 & Wild Cave National Park & 28,060 \\
2 & Bad lands Wilderness & 64,250
\end{tabular}




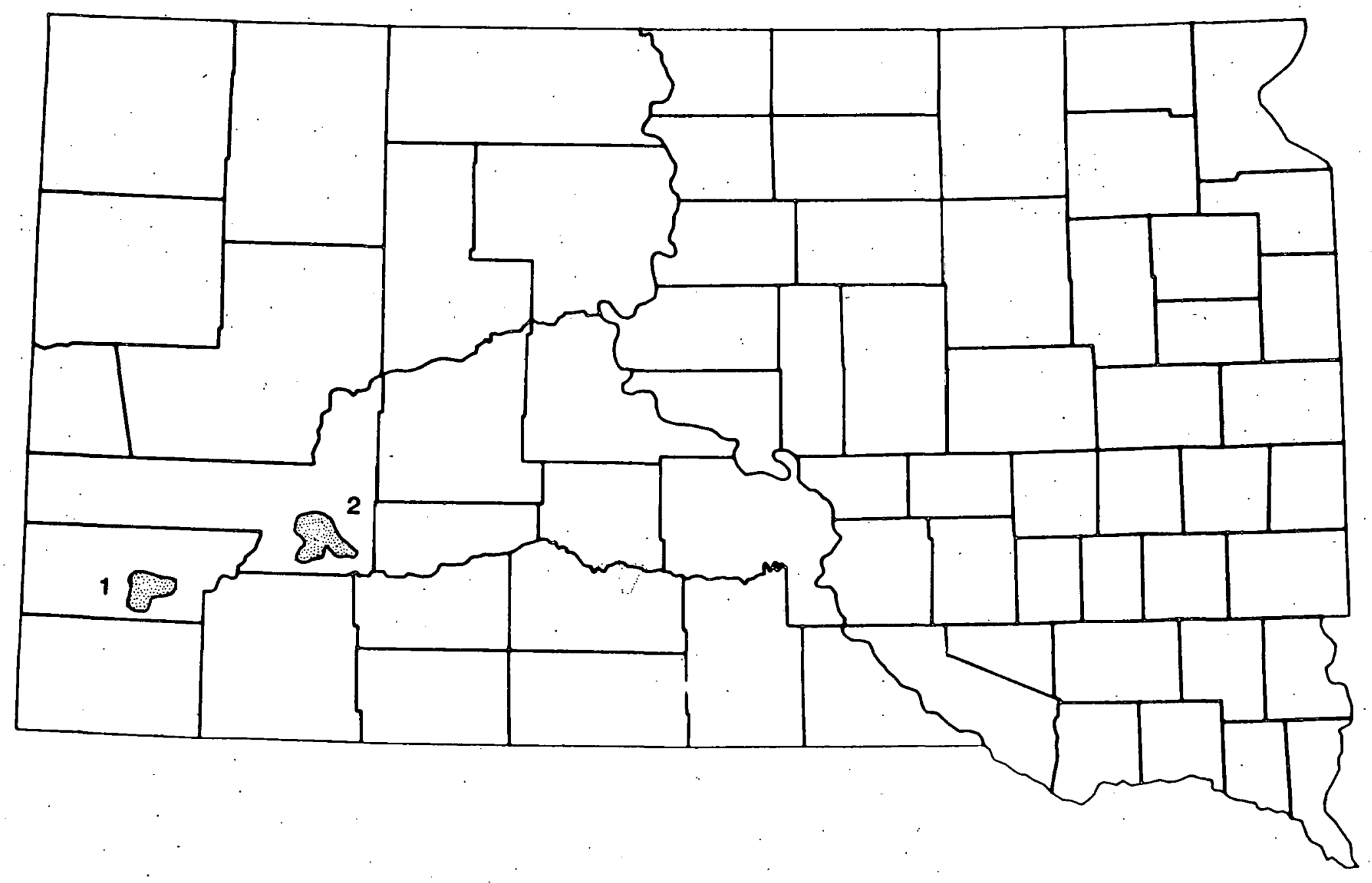

Fig. C:25 South Dakota: PSD Class I Areas 


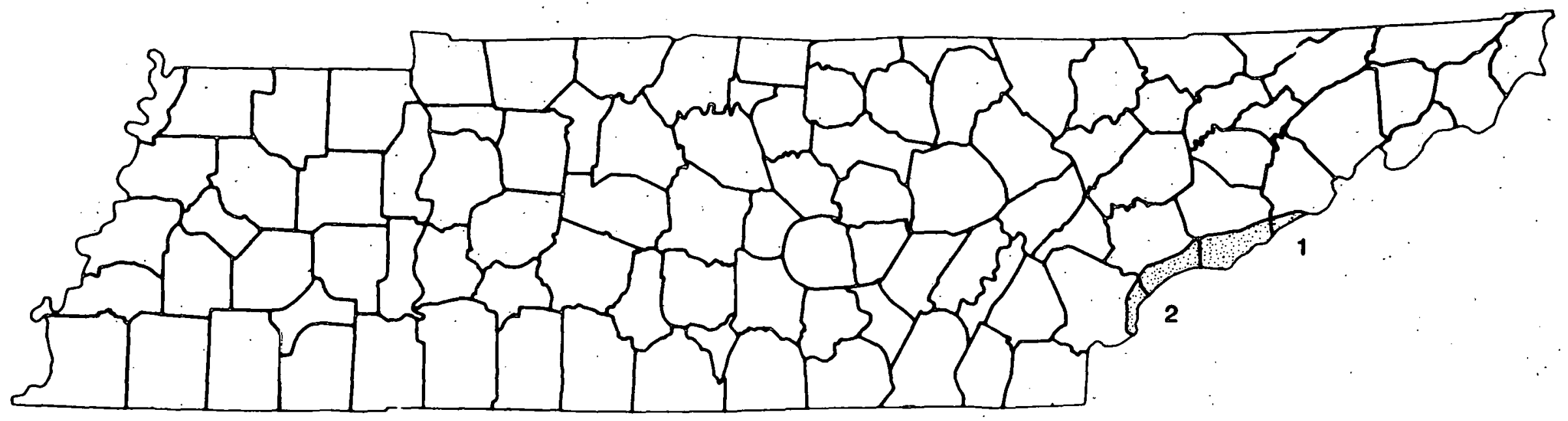

Fig. C.26 Tennessee: PSD Class I Areas 
Table C.27 Texas: PSD Class I Areas

\begin{tabular}{clrr}
\hline Location & \multicolumn{1}{c}{ Area Name } & Acreage \\
\hline 1 & Guadalupe Mountains National Park & 76,292 \\
2 & Big Bend National Park & $\ddots$ & 708,118 \\
\hline
\end{tabular}




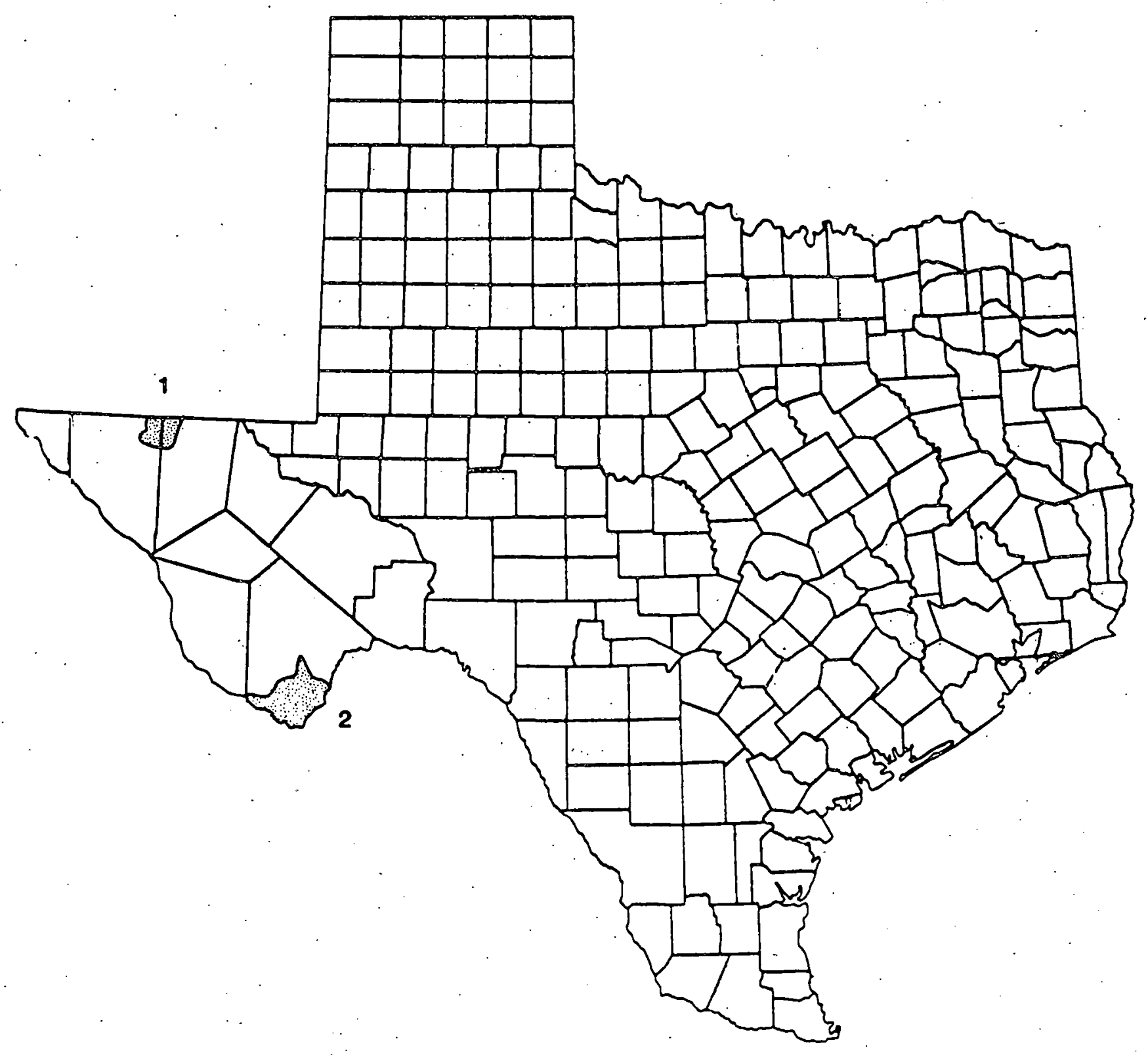

Fig. C.27 Texas: PSD Class I Areas 
Tab.le C.28' Utah: PSD Class I Areas

\begin{tabular}{clr}
\hline Location & \multicolumn{1}{c}{ Area Name } & Acreage \\
\hline 1 & Arches National Park & 65,098 \\
2 & Capitol Reef National Park & 221,896 \\
3 & Canyonlands National Park & 337,570 \\
4 & Bryce Canyon National Park & 35,832 \\
5 & Zion National Park , & 142,462
\end{tabular}


239

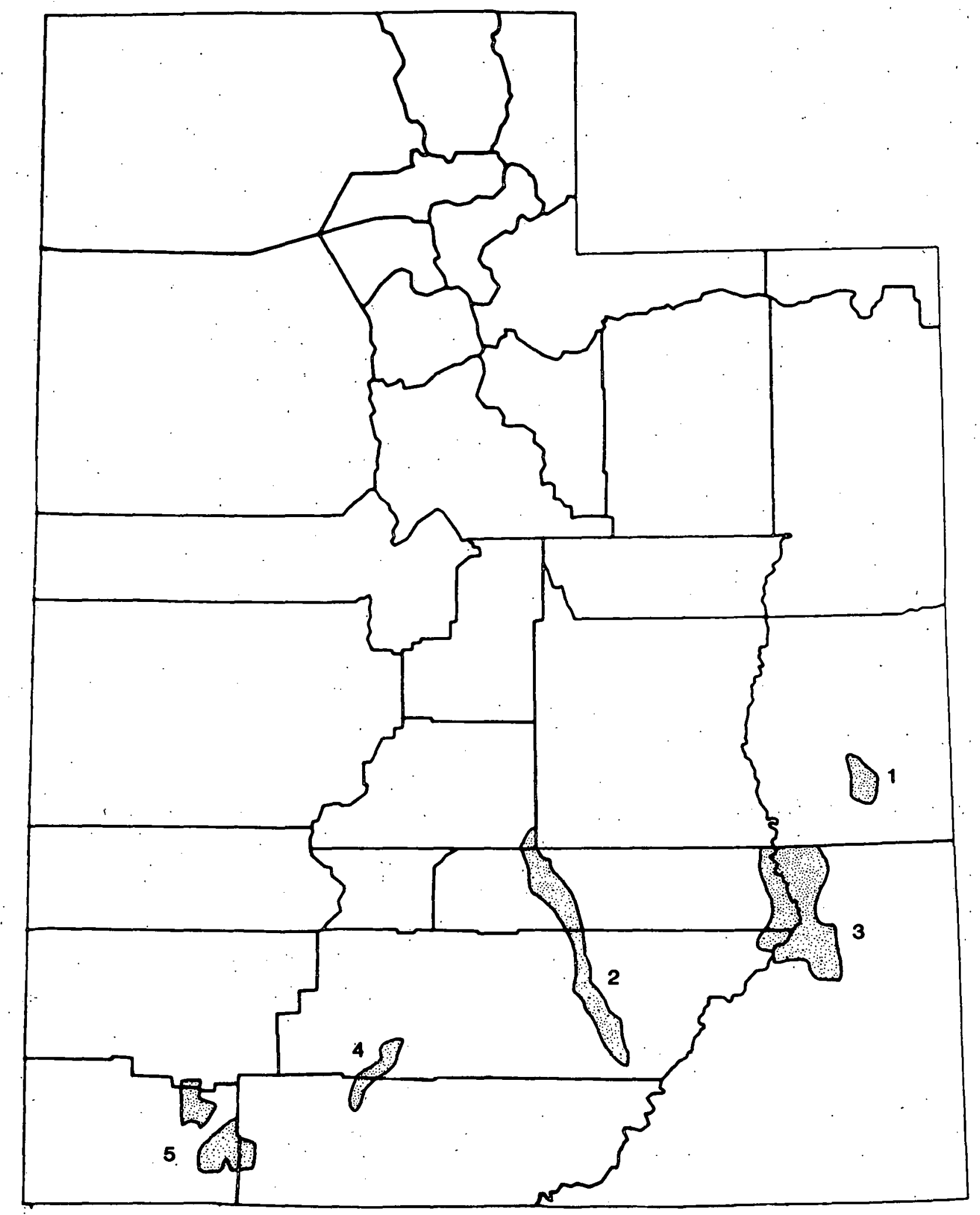

Fig. C.28 Utah: PSD Class I Areas. 
240

Table C.29. Vermont: PSD Class I Area

\begin{tabular}{cccc}
\hline Location & Area Name & Acreage \\
\hline 1 & Lyle Brook Wilderness & 12,430 \\
\hline
\end{tabular}




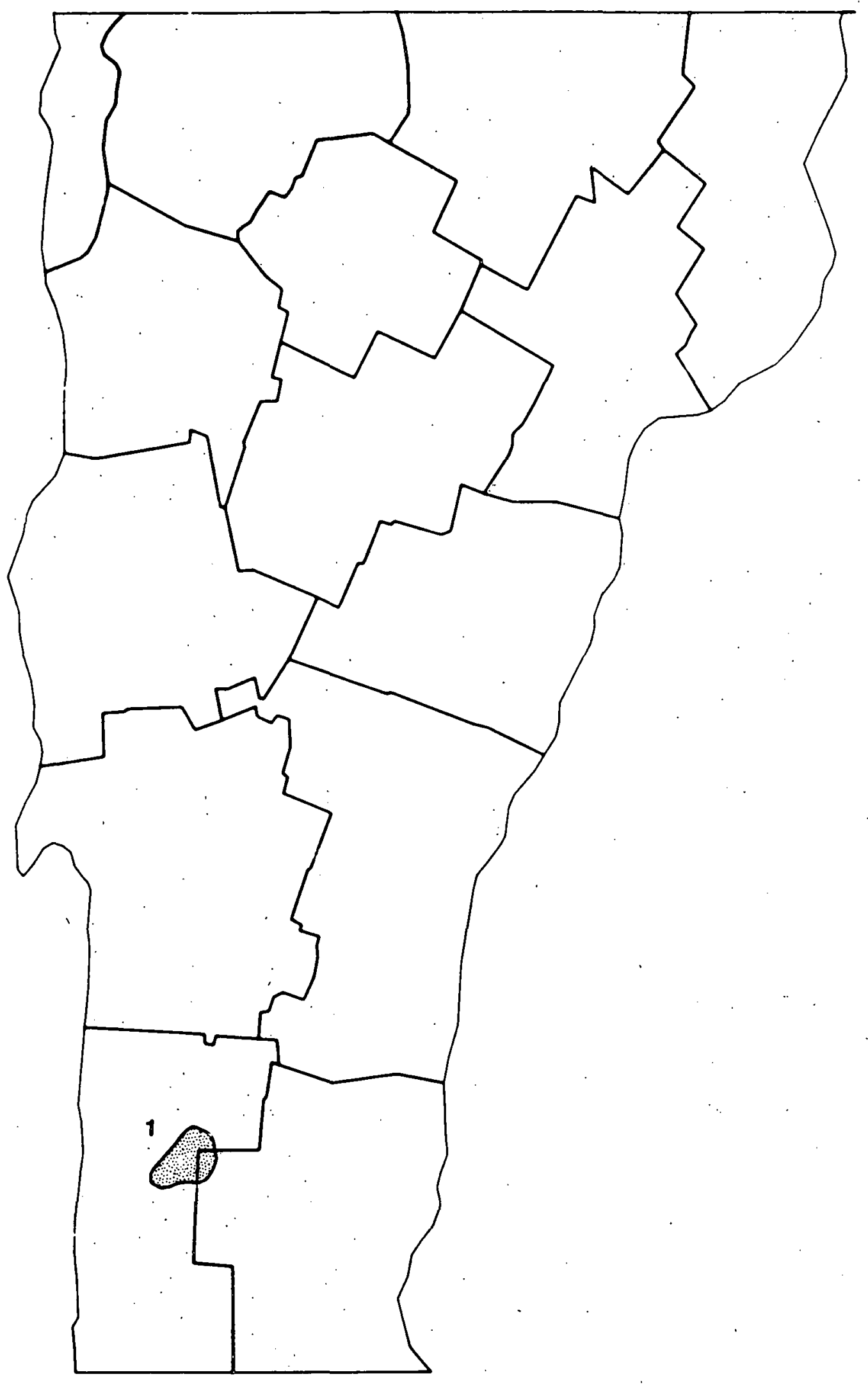

Fig. C.29 Vermont: PSD Class I Area 
Table C.30 Virginia: PSD Class I Areas

\begin{tabular}{ccc}
\hline Location & Area Name & Acreage \\
\hline 1 & Shenandoah National Park & 190,535 \\
2 & James River Face Wilderness & 8,703 \\
\hline
\end{tabular}




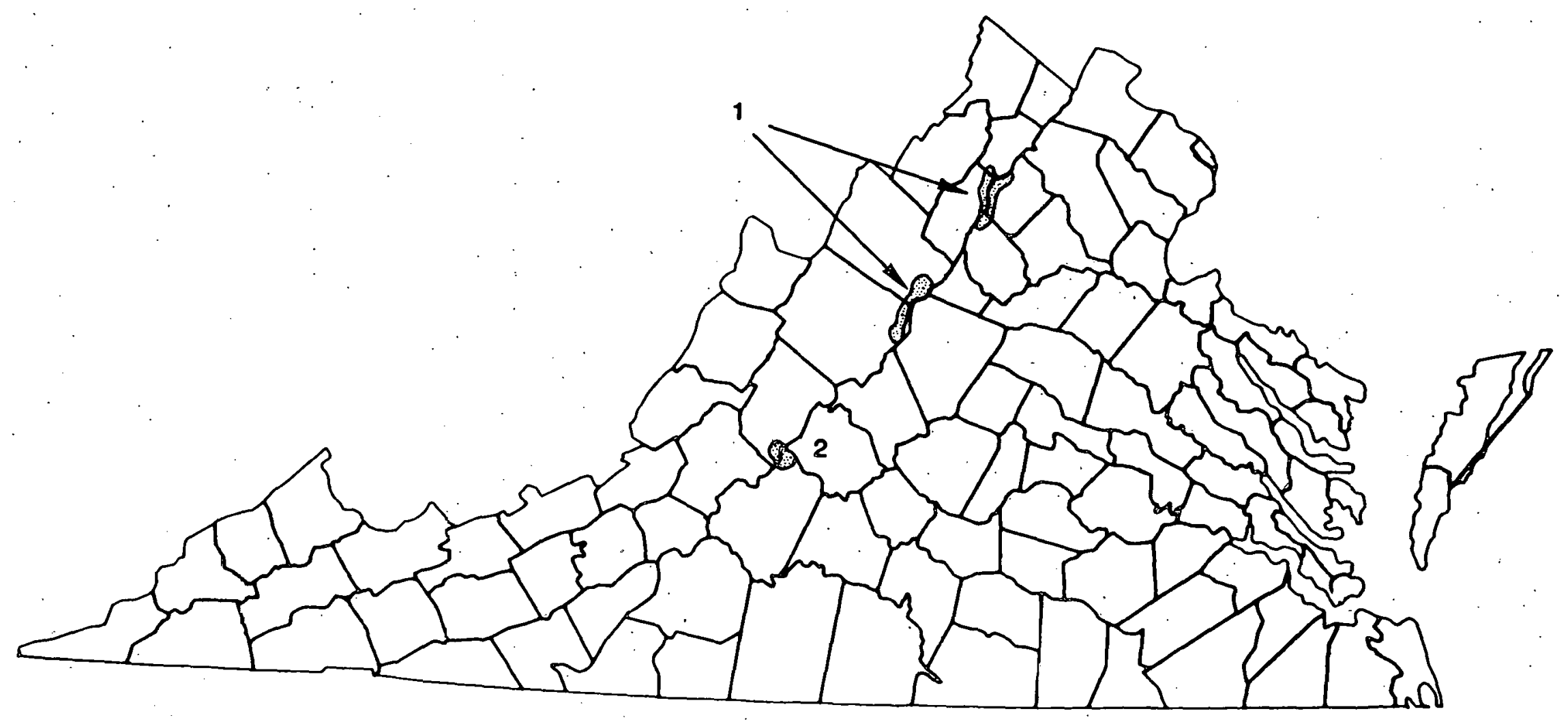

Fig. C. 30 Virginia: PSD Class I Areas 
Table C.31 Washington: PSD Class "I Areas:

\begin{tabular}{clr}
\hline Location & \multicolumn{1}{c}{ Area Name } & Acreage \\
\hline 1 & North Cascades National Park & 503,277 \\
2 & Pasayten Wilderness & 505,524 \\
3 & Glacier Peak Wilderness & 464,258 \\
4 & Olympic National Park & 892,578 \\
5 & Alpine Lakes Wilderness & 303,508 \\
6 & Mount Rainier National Park & 235,239 \\
7 & Goat Rocks Wilderness & 82,680 \\
8 & Mount Adams Wilderness & 32,356 \\
\hline
\end{tabular}




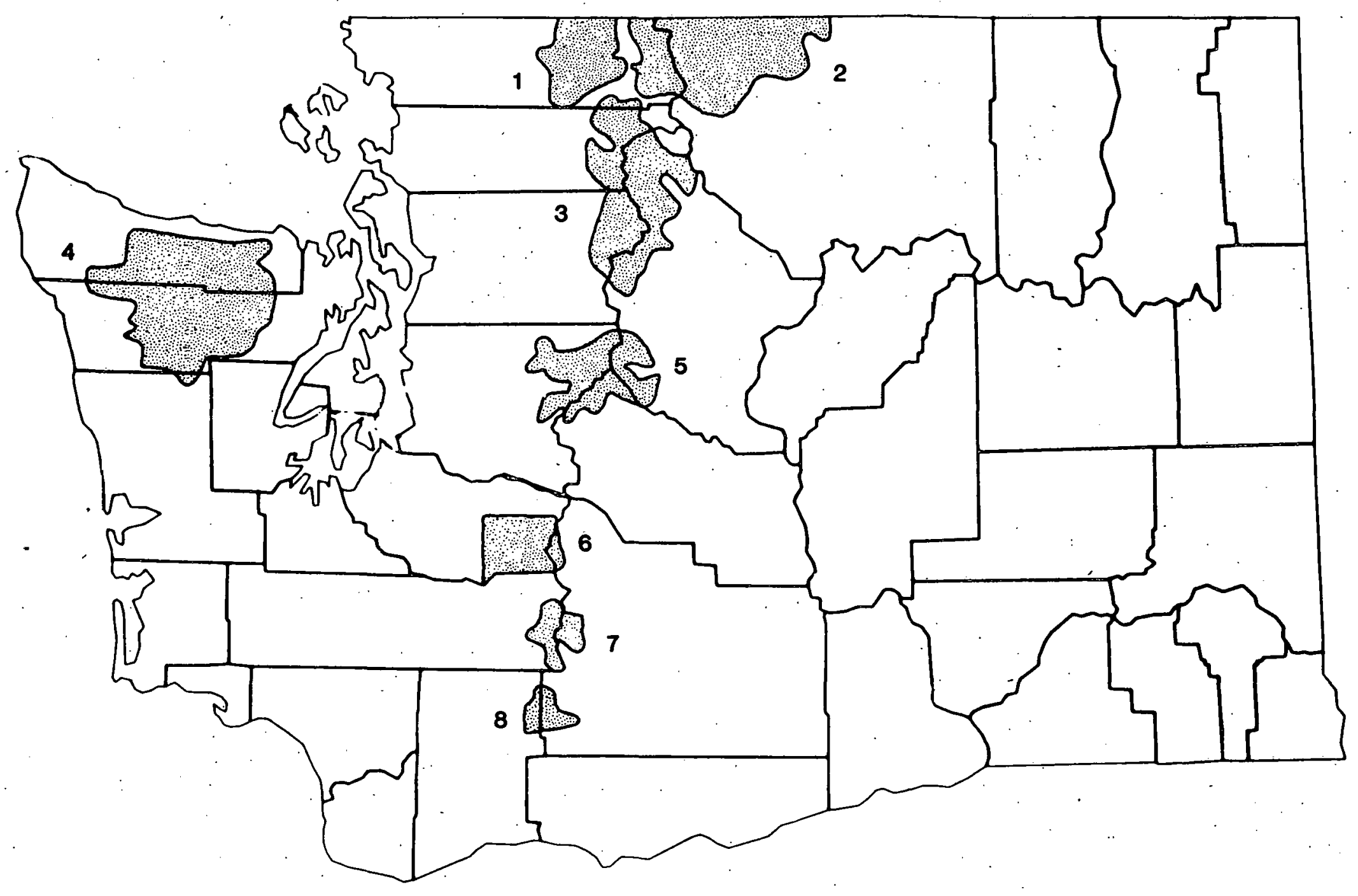

Fig. C.31 Washington: PSD Class I Areas 
Table C.32 West Virginia: PSD Class I Areas

\begin{tabular}{ccc}
\hline Location & Area Name & Acreage \\
\hline 1 & Otter Creek Wilderness & 20,000 \\
2 & Dolly Sods Wilderness & 10,215
\end{tabular}




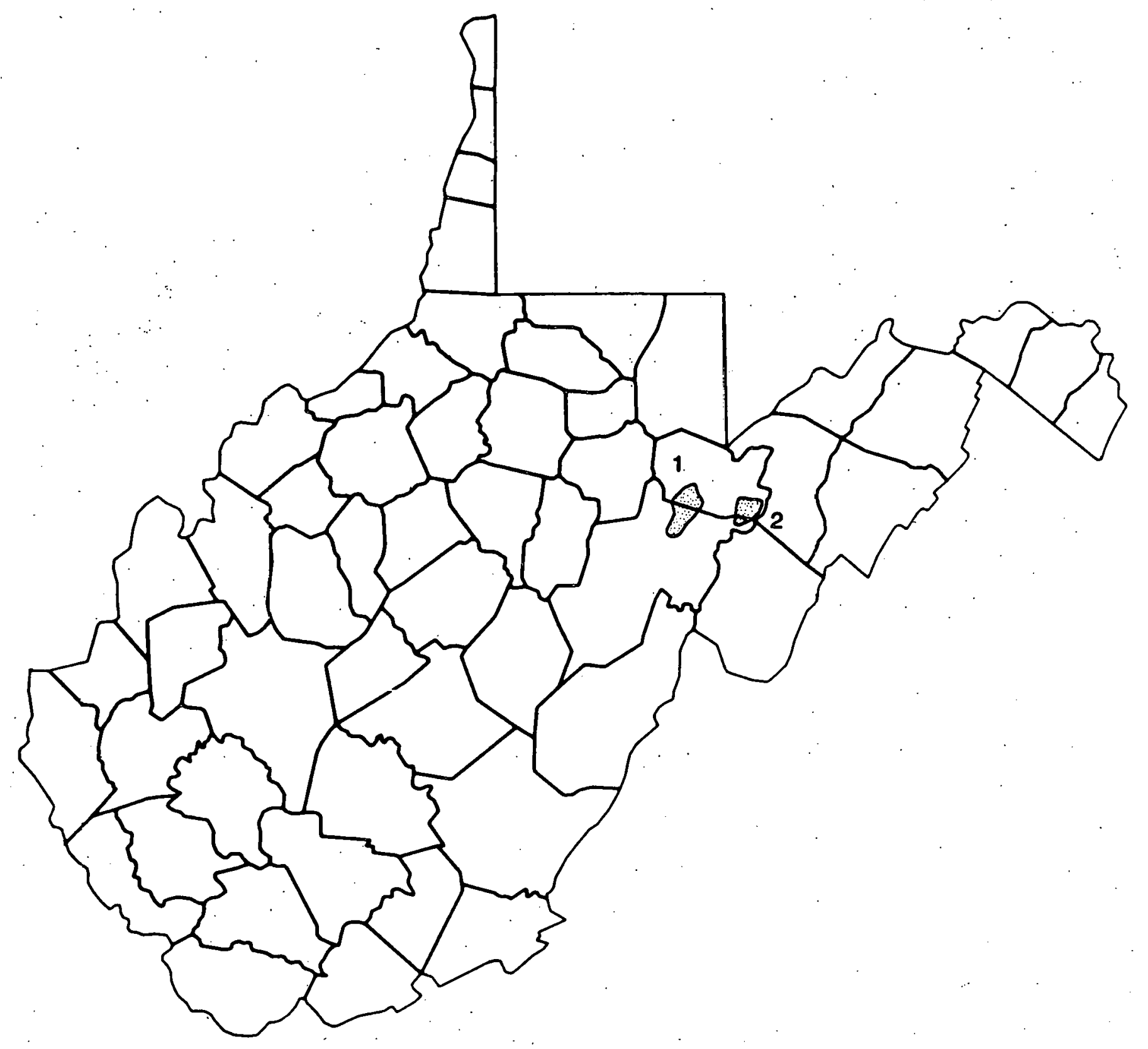

Fig.:C. 32 West Virginia: PSD Class I Areas 
248

Table C.33 Wisconsin: PSD Class I Area

\begin{tabular}{ccc}
\hline Location & Area Name & Acreage \\
\hline 1 & Rainbow Lake Wilderness & 6,583 \\
\hline
\end{tabular}


249

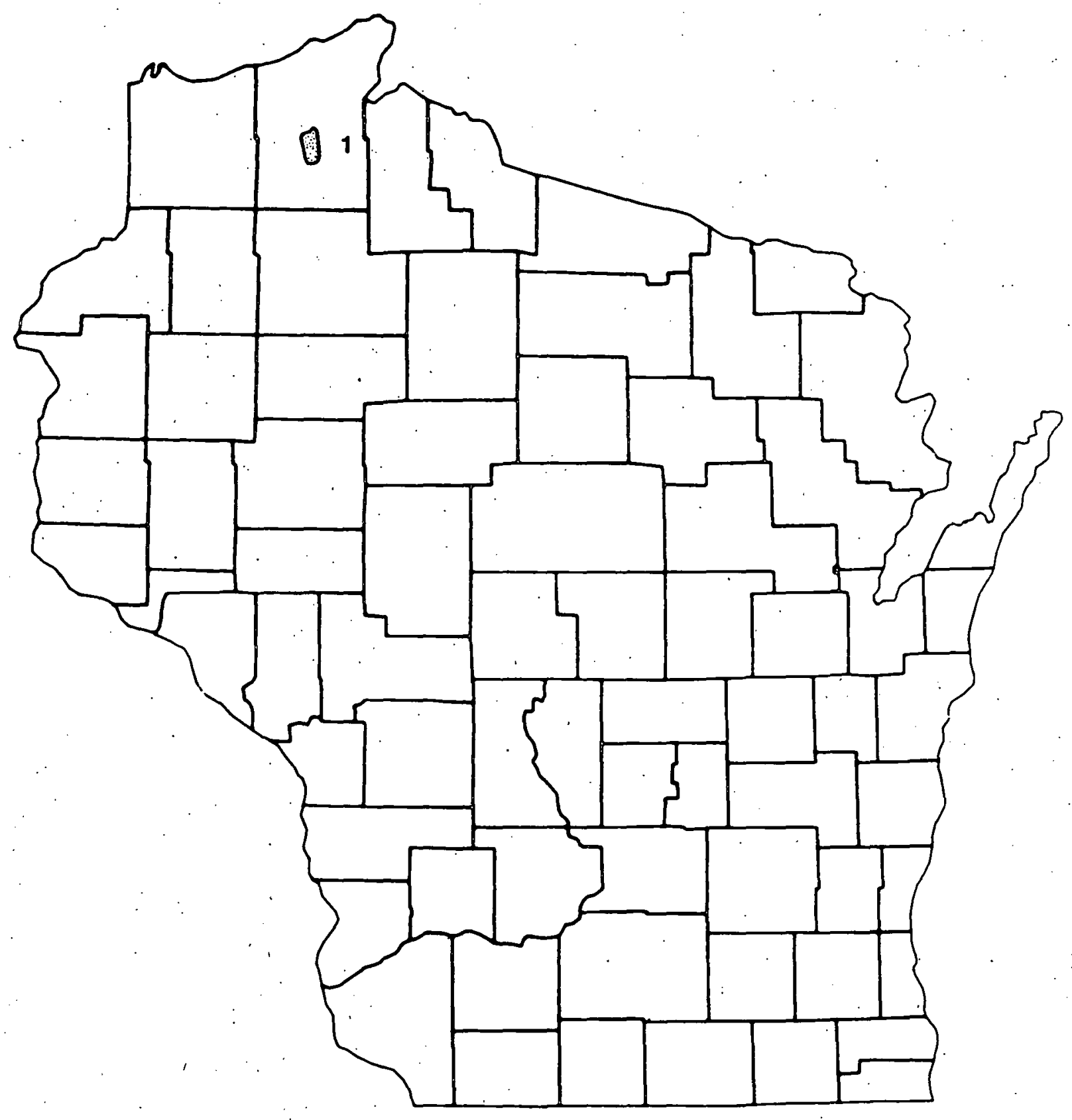

Fig. C.33 Wisconsin: PSD Class I Area 
Table C.34 Wyoming: PSD Class I Areas

\begin{tabular}{clc}
\hline Location & \multicolumn{1}{c}{ Area Name } & Acreage \\
\hline 1 & Yellowstone National Park & $2,020,625^{a}$ \\
2 & North Absaroka Wilderness & 351,104 \\
3 & Grand Teton National Park & 305,504 \\
4 & Teton Wilderness & 557,311 \\
5 & Washakie Wilderness & 686,584 \\
6 & Bridger Wilderness & 392,160 \\
7 & Fitzpatrick Wilderness & 191,103 \\
\hline
\end{tabular}

aYellowstone National Park, 2,219,737 acres overall, includes regions in Idaho and Montana. 

THIS PAGE

WAS INTENTIONALLY

LEFT BLANK 


$$
=
$$


THIS PAGE

\section{WAS INTENTIONALLY LEFT BLANK}




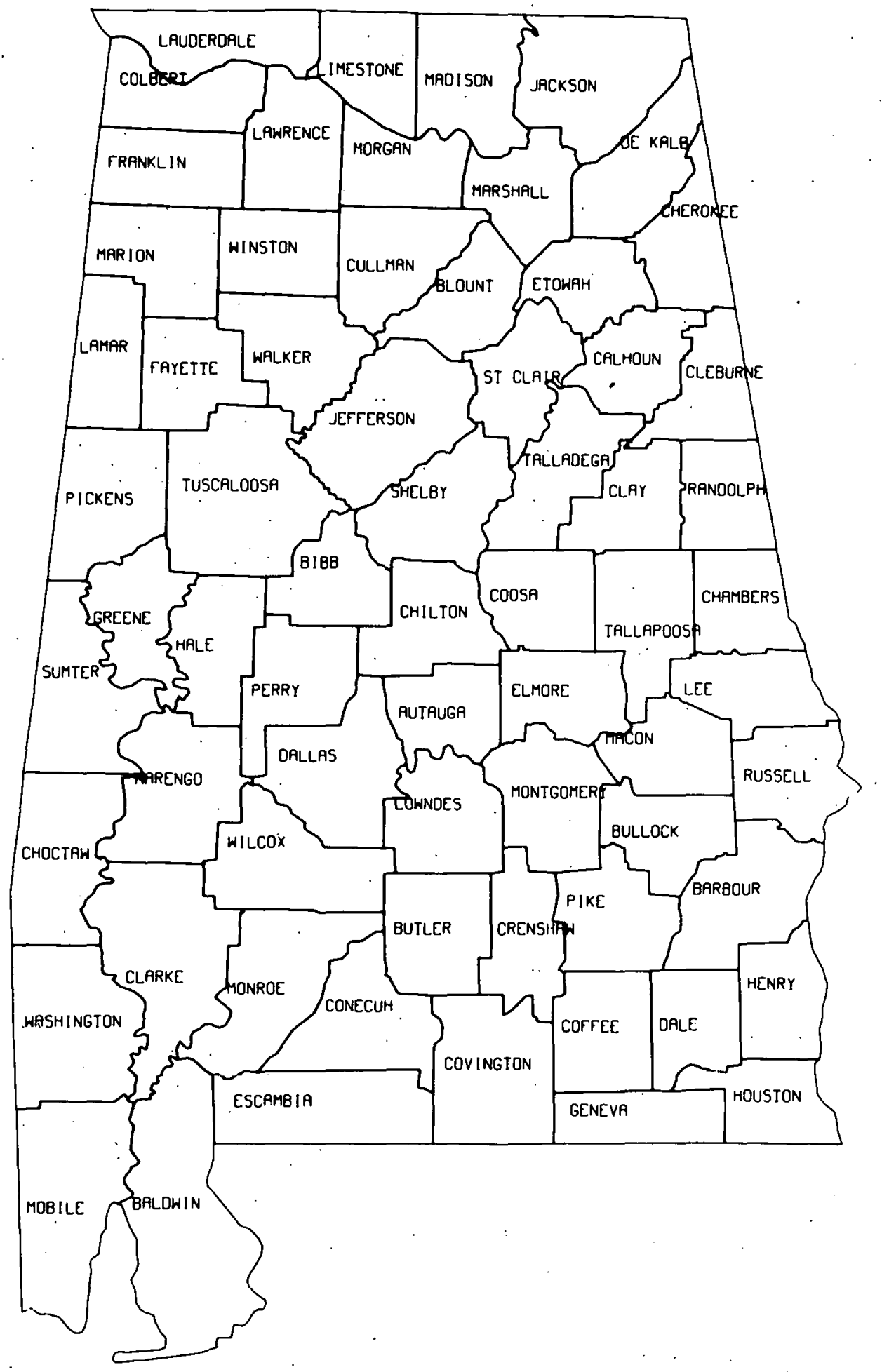

Fig. D.1 Alabama: Key to Counties 


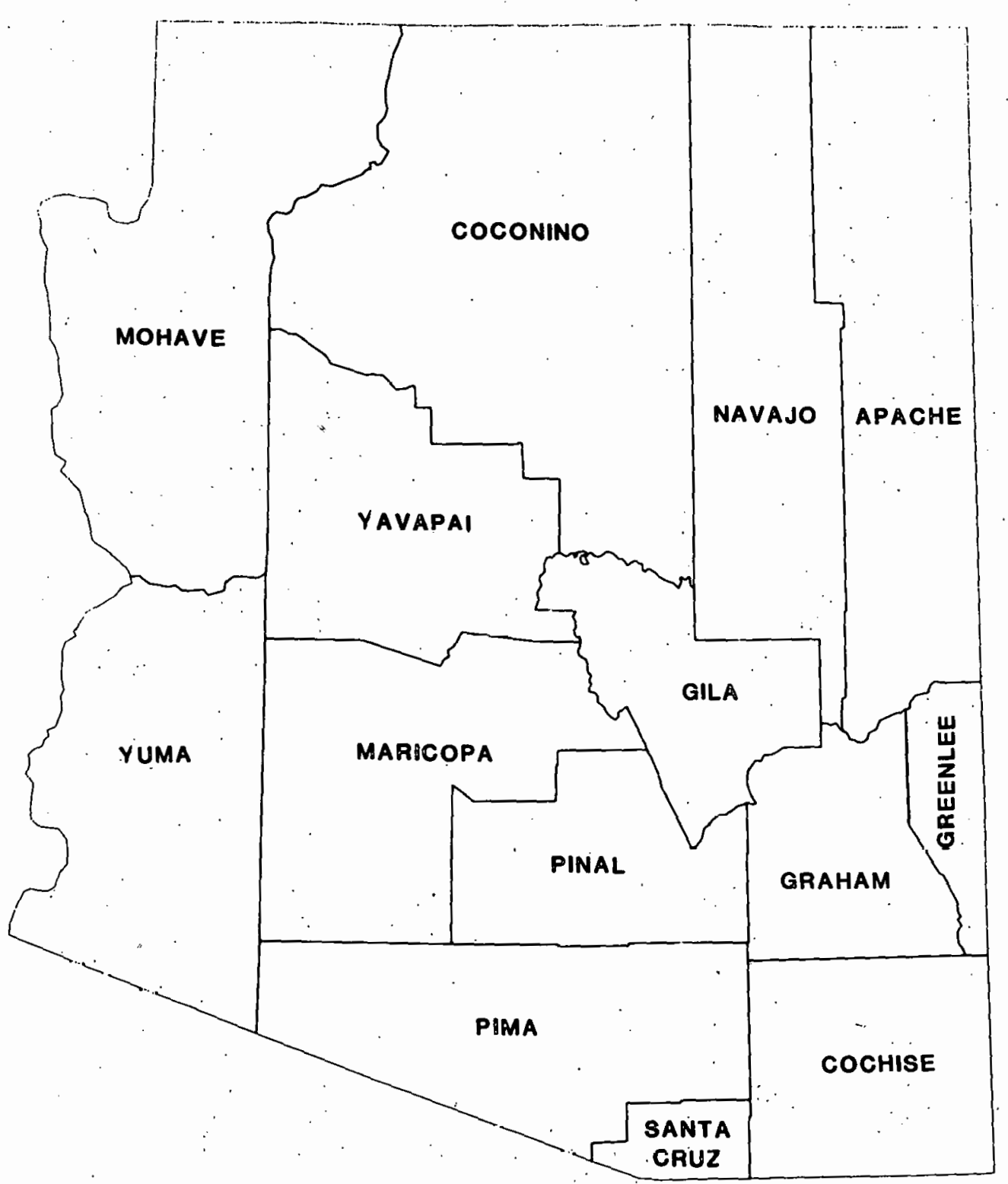

Fig. D.2 Arizona: Key to Counties 


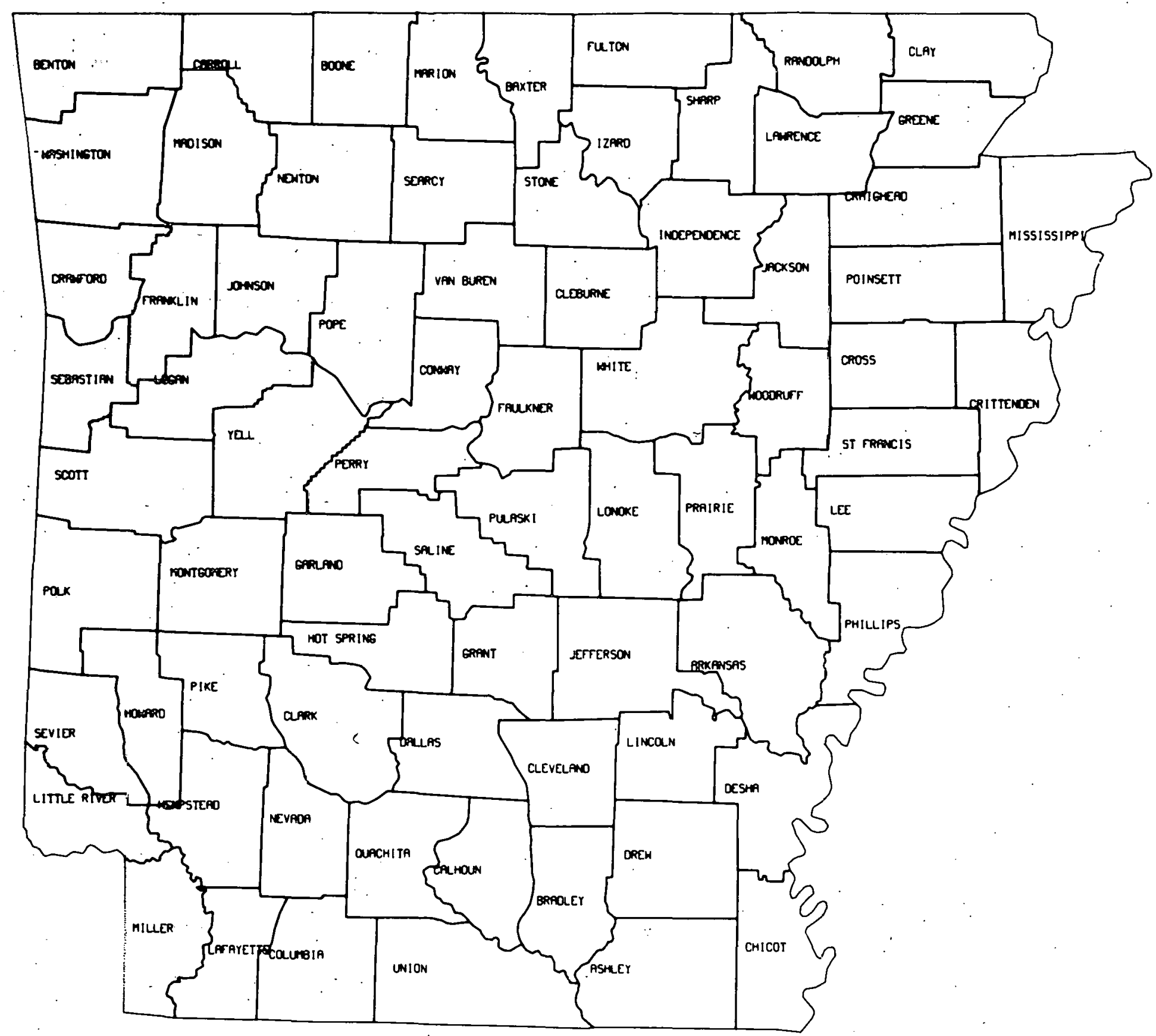

Fig. D.3 Arkansas: Key to Counties 


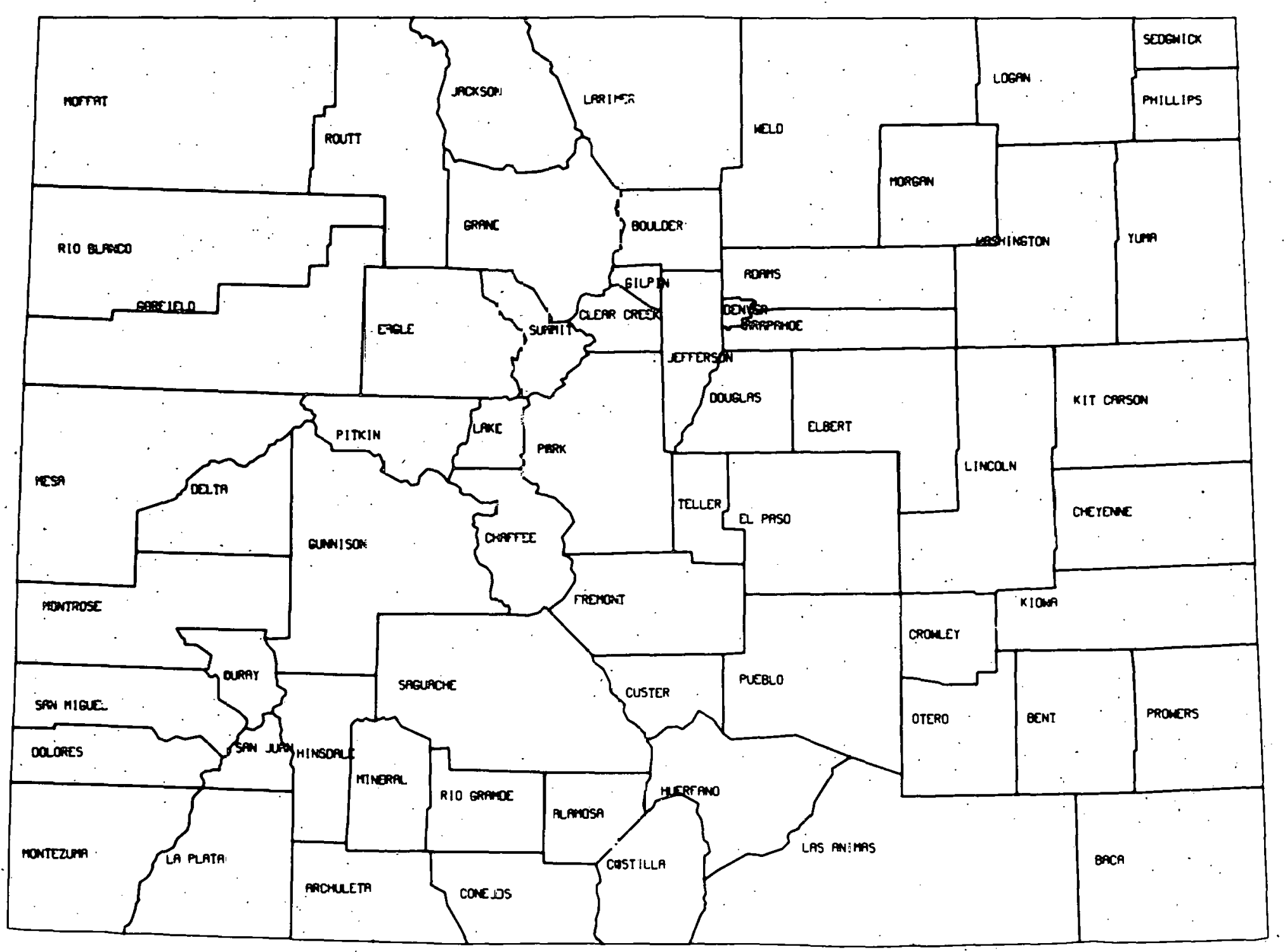

Fig. D.4 Solorado: Key to Counties 


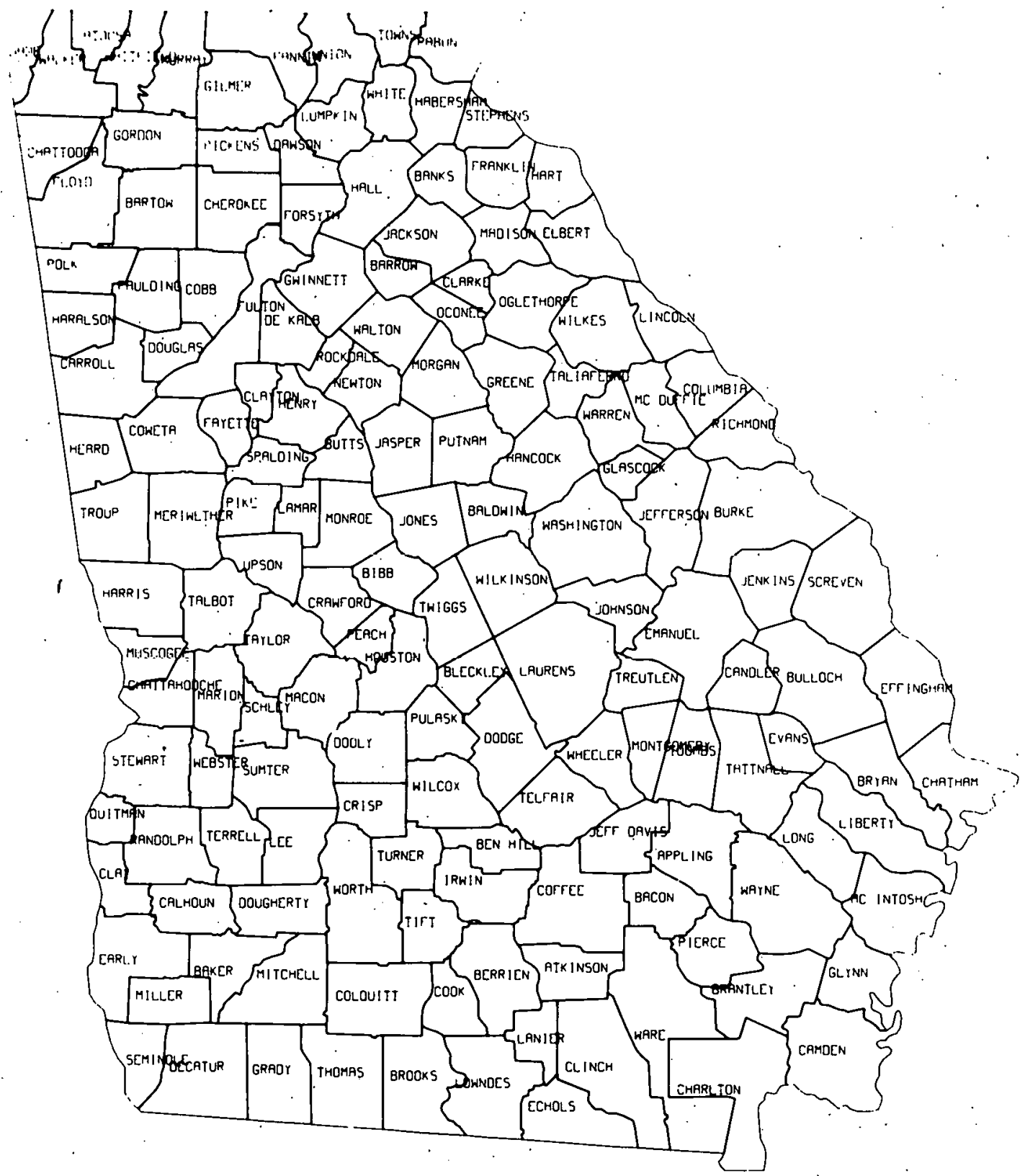

Fig. D.5 Georgia: Key to Counties 


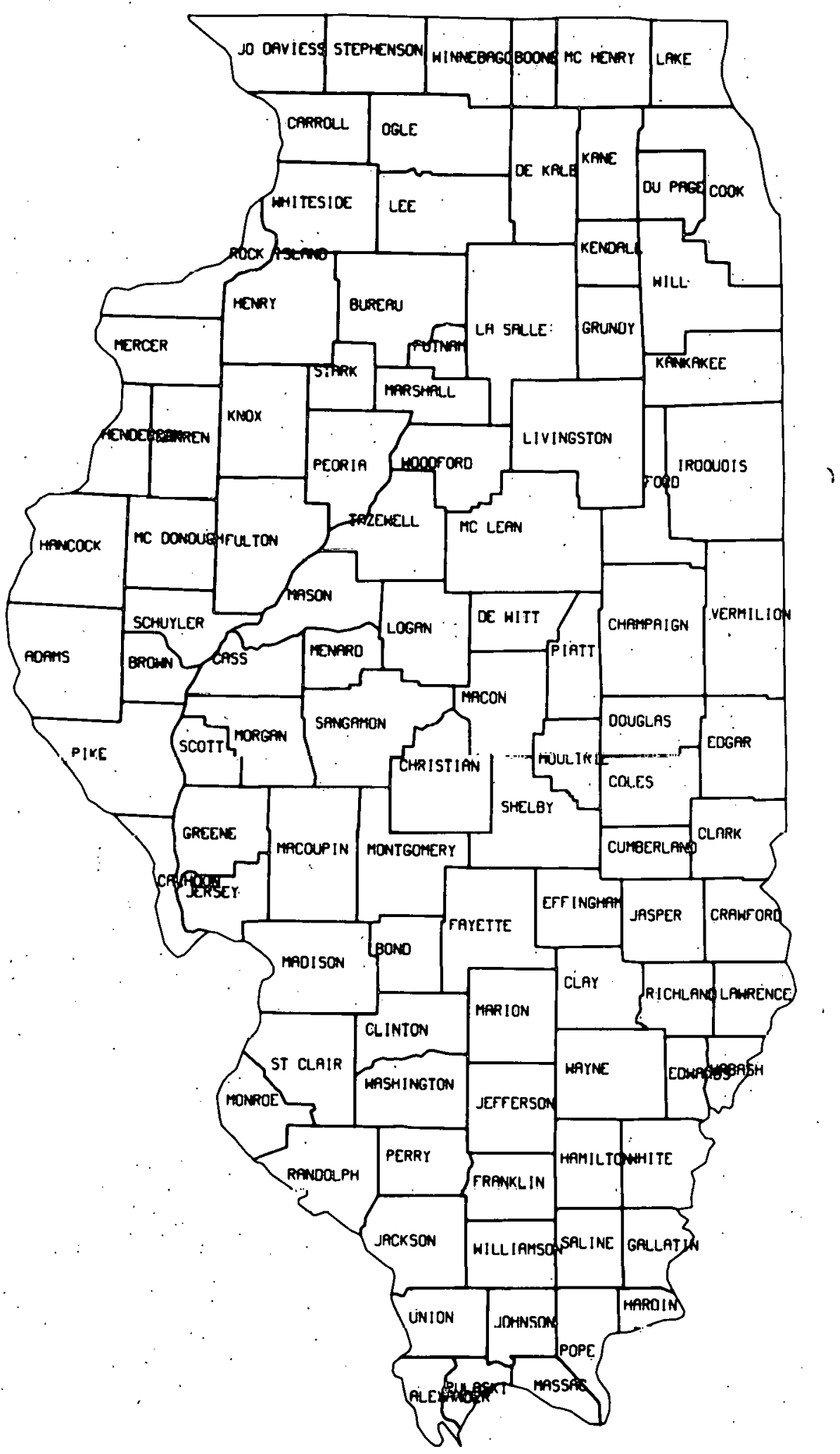

Fig. D.6 Illinois: Key to Counties 


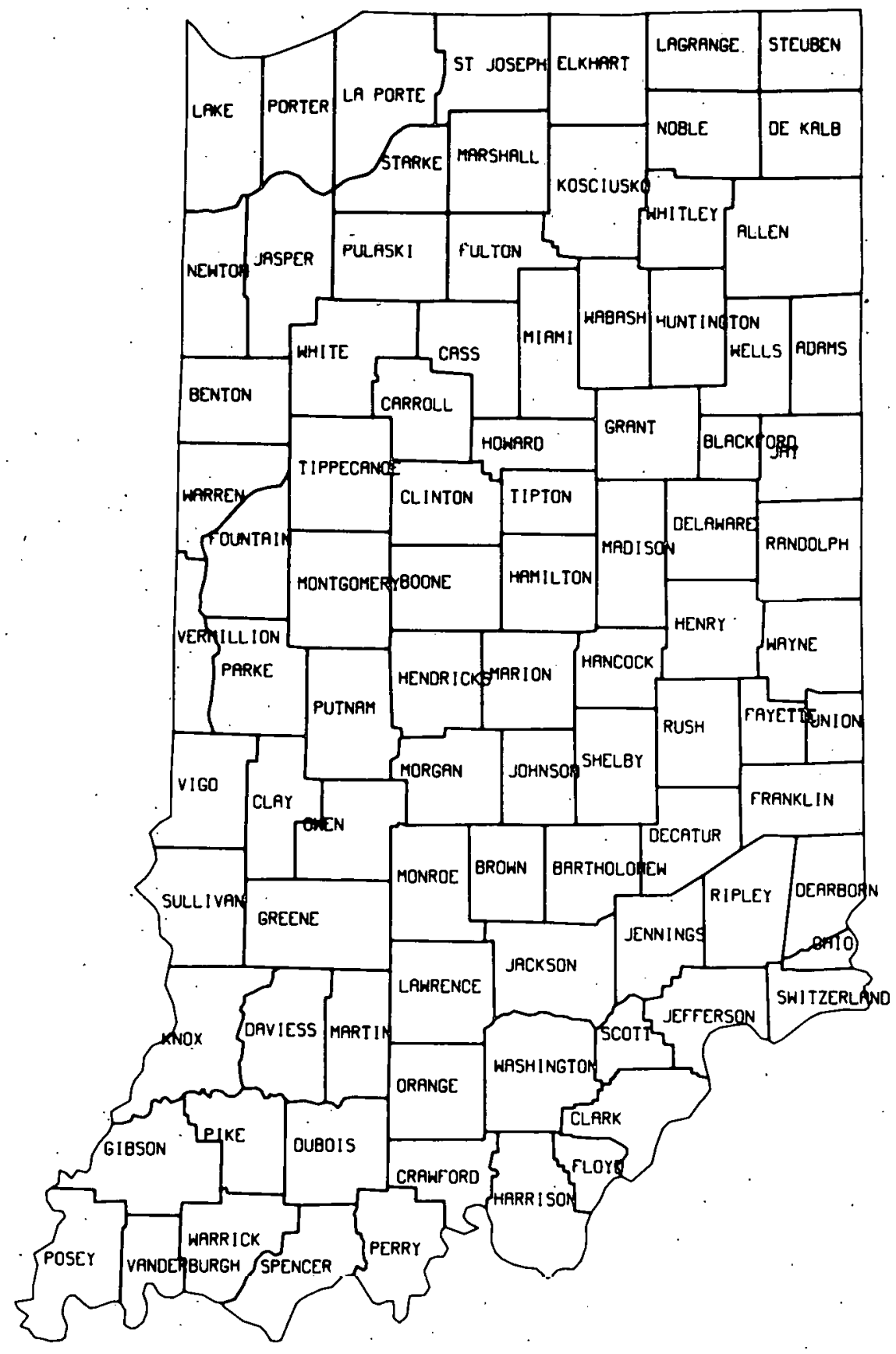

Fig. D.7 Indiana: Key to Counties 


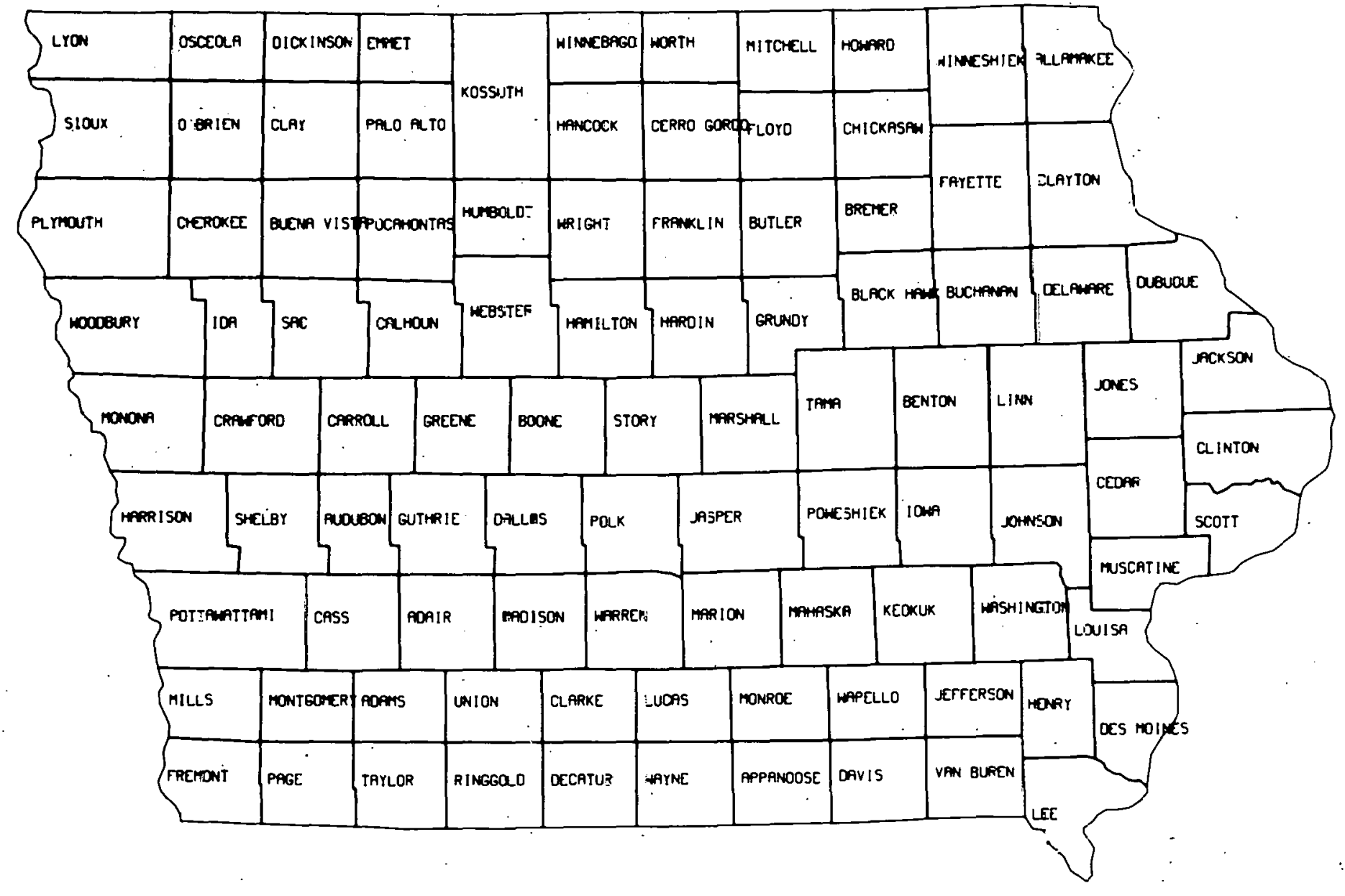

Fig. D.8 Iowa: Key to Counties 


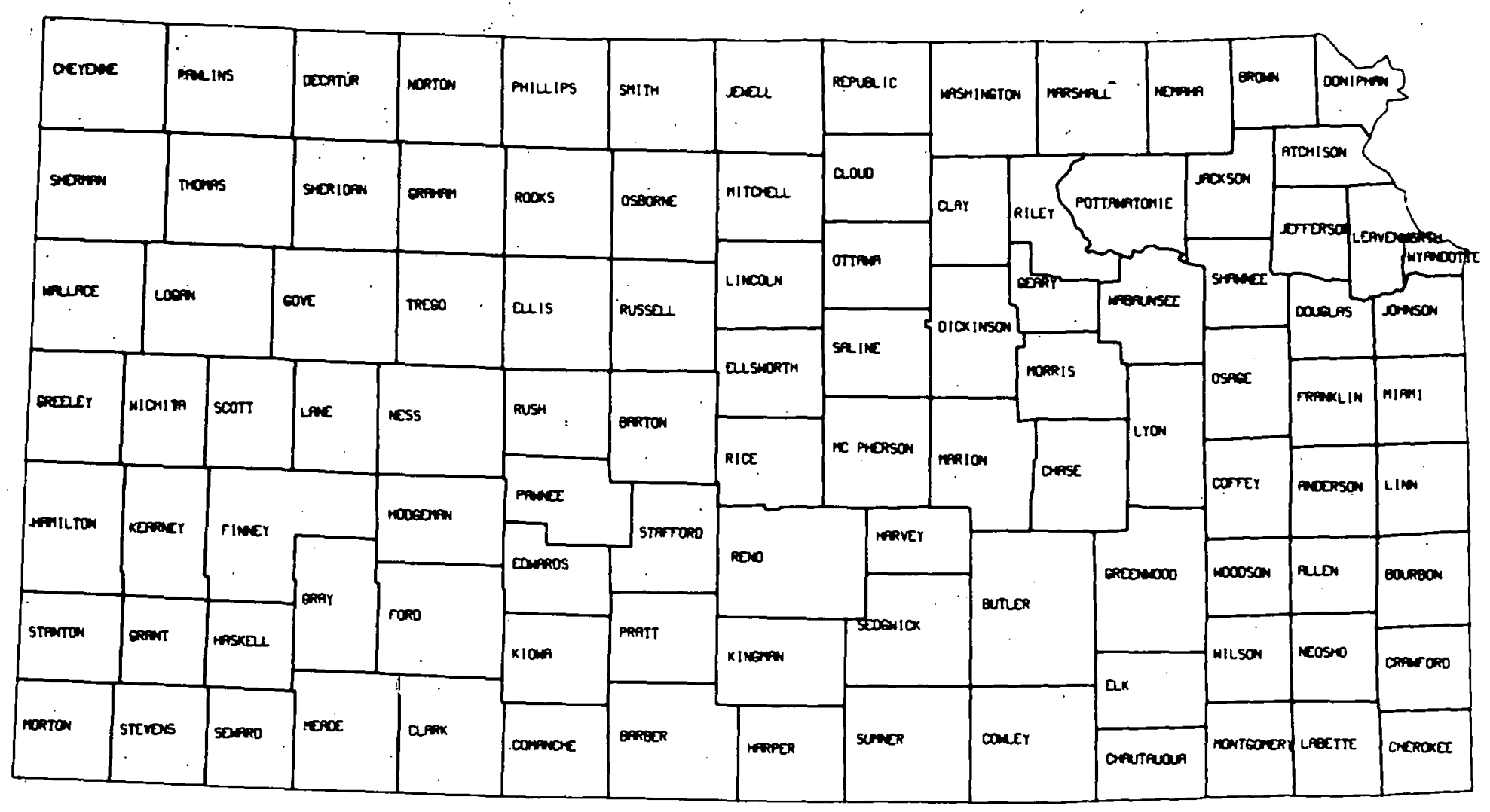

Fig. D.9 Kansas: Key to Counties 


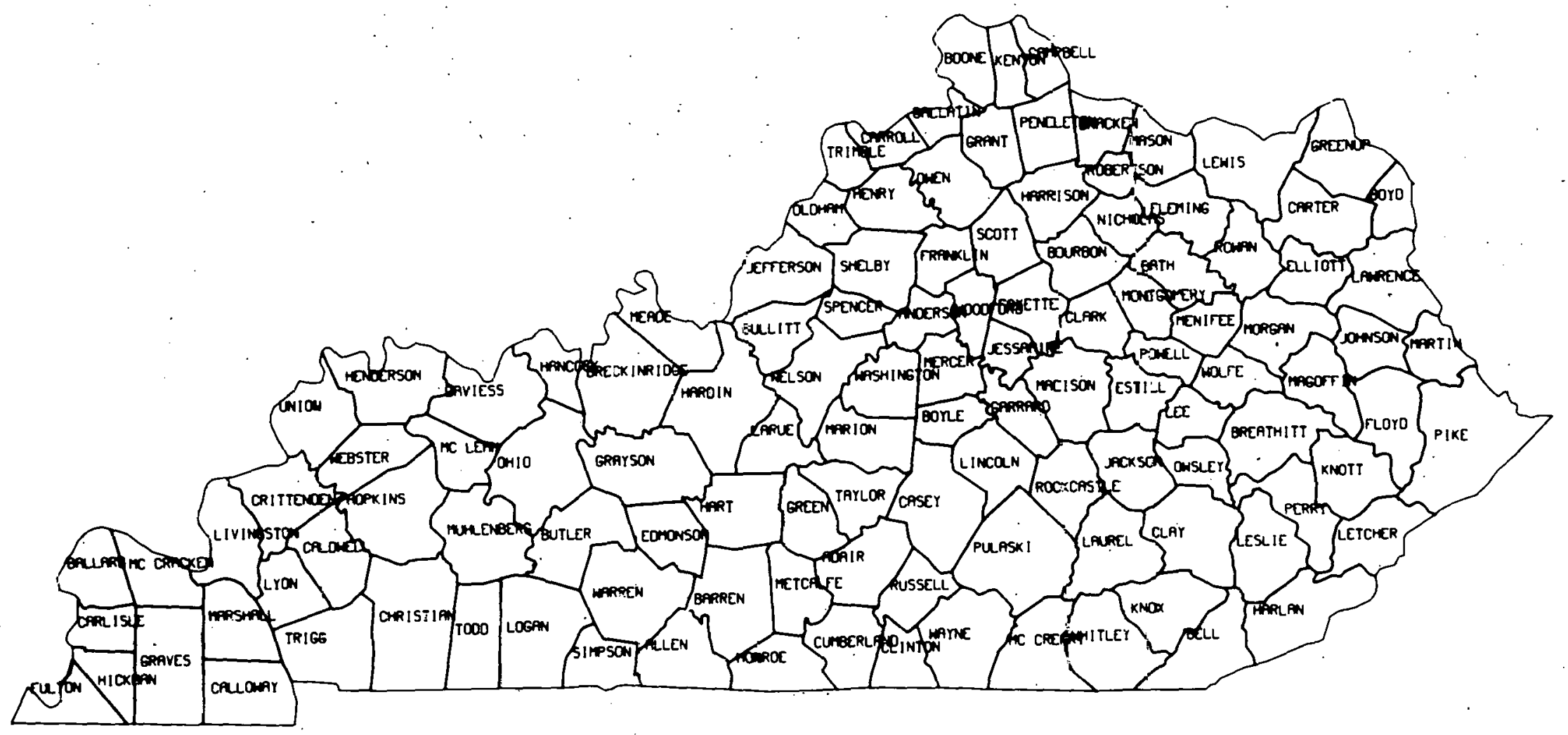

Fig. D:10 Kentucky: Key to Counties 


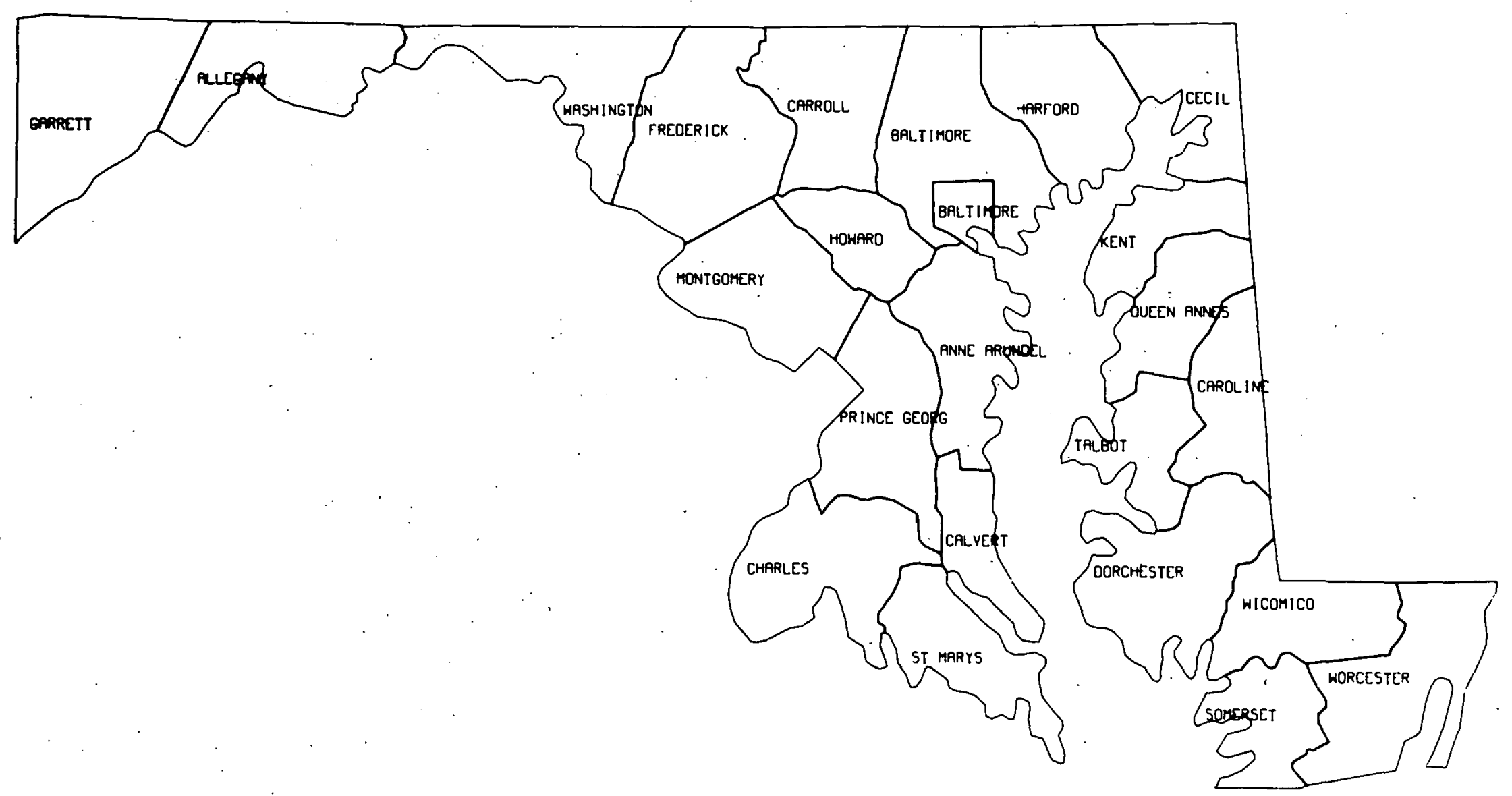

N

Fig. D.11 Maryland: Key to Counties 


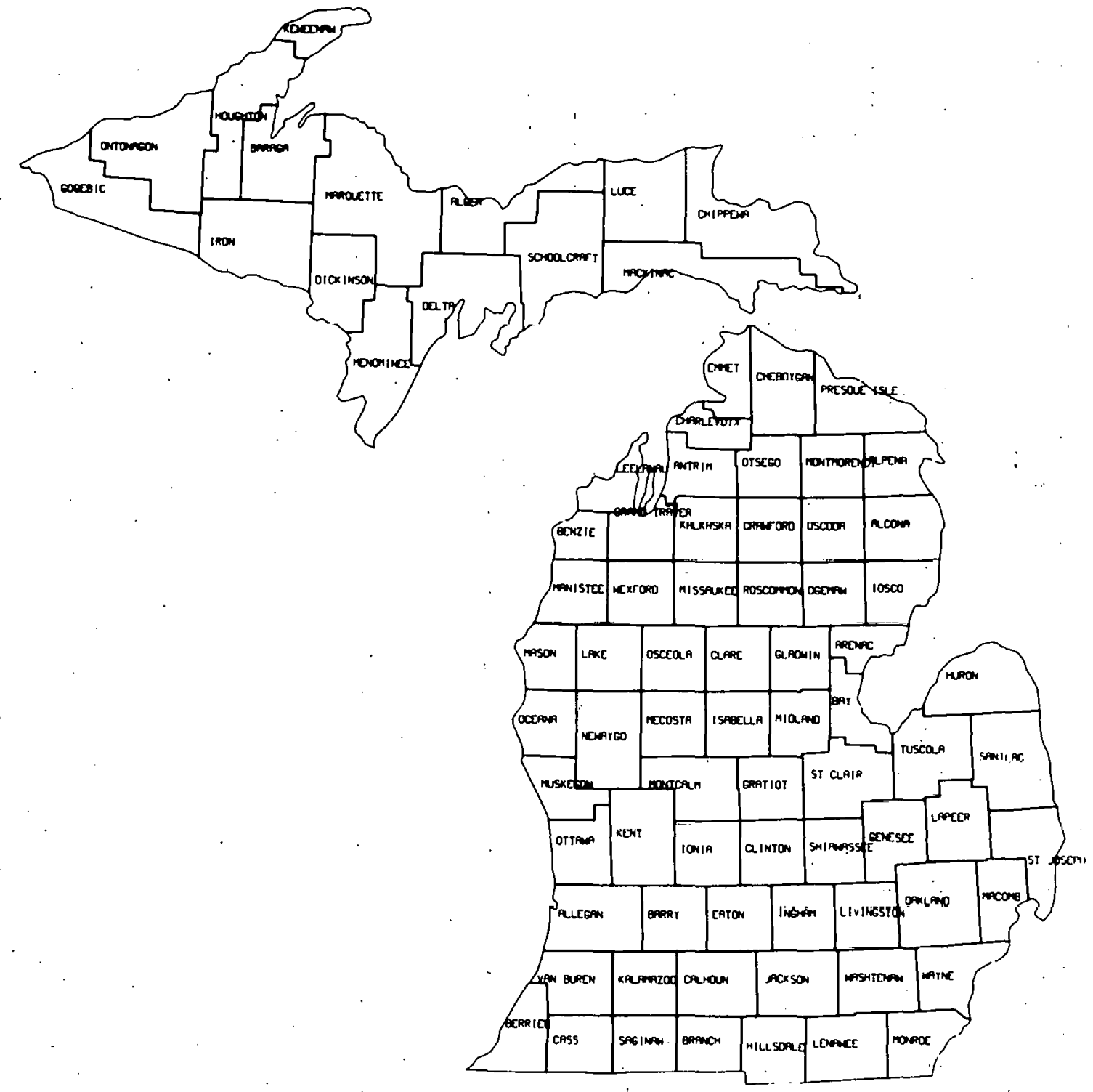

Fig. D.12 Michigan: Key to Counties 


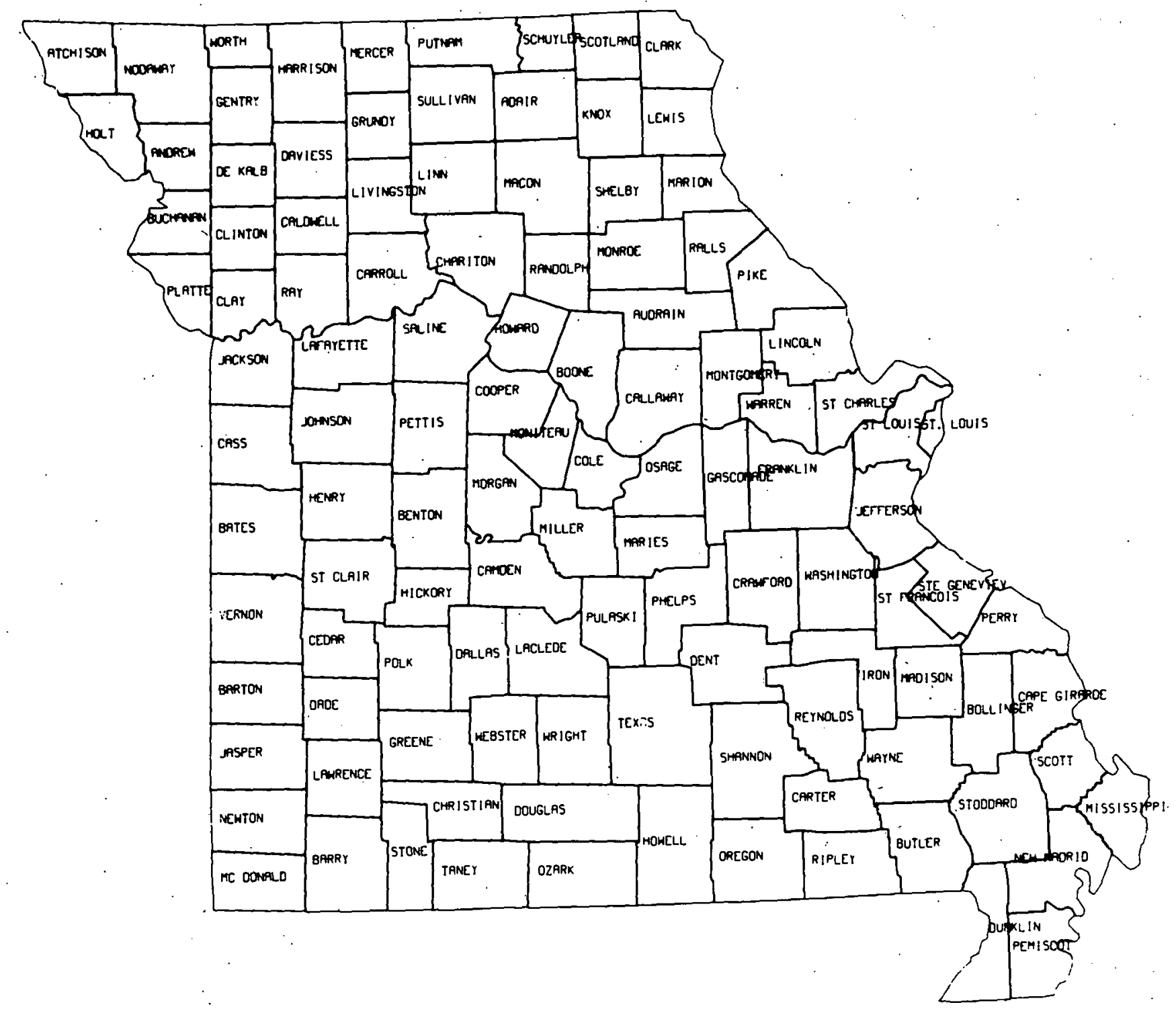

Fig. D.13 Missouri: Key to Counties 


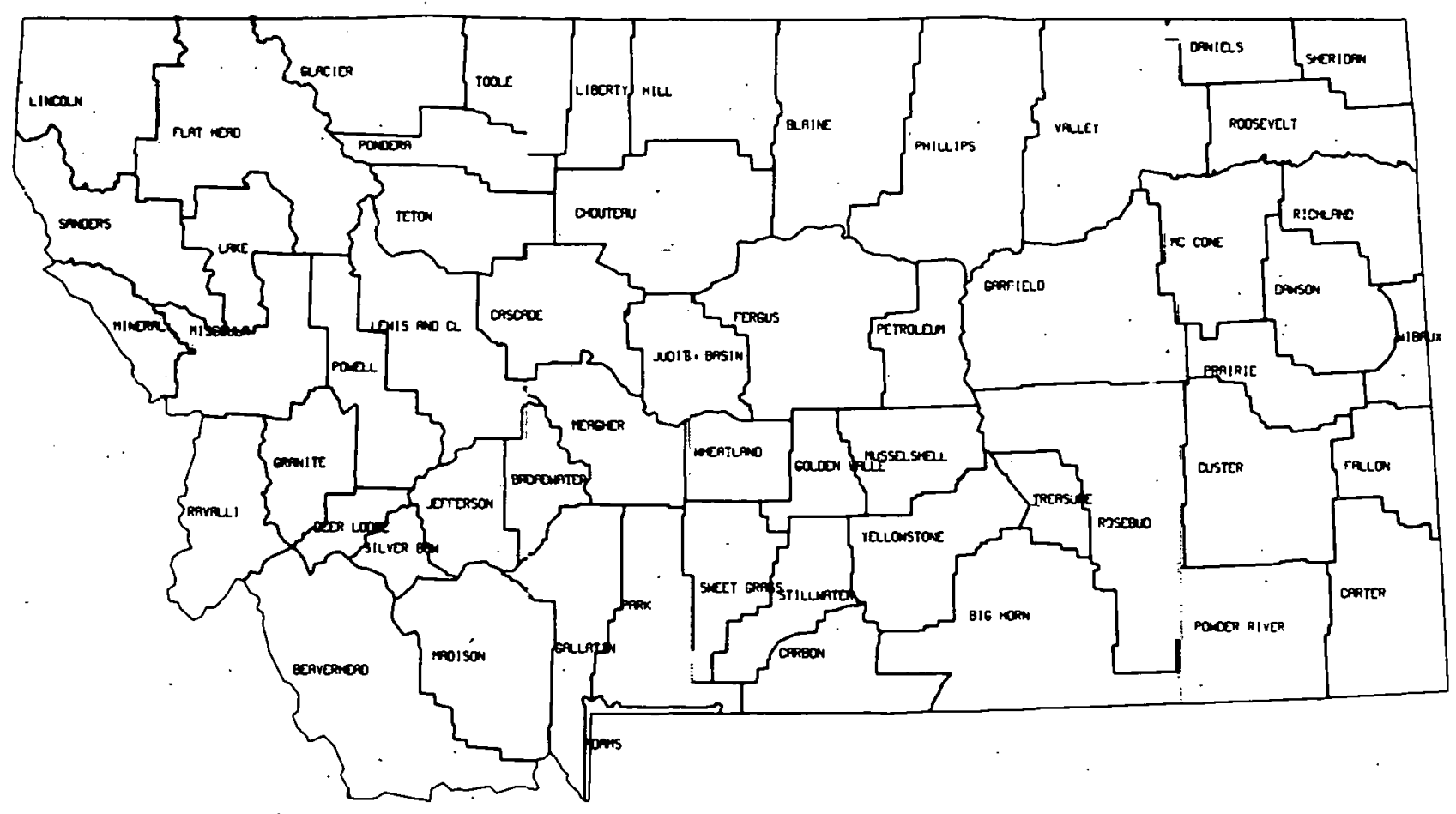

Fig. D.14 Montana: Key to Counties 


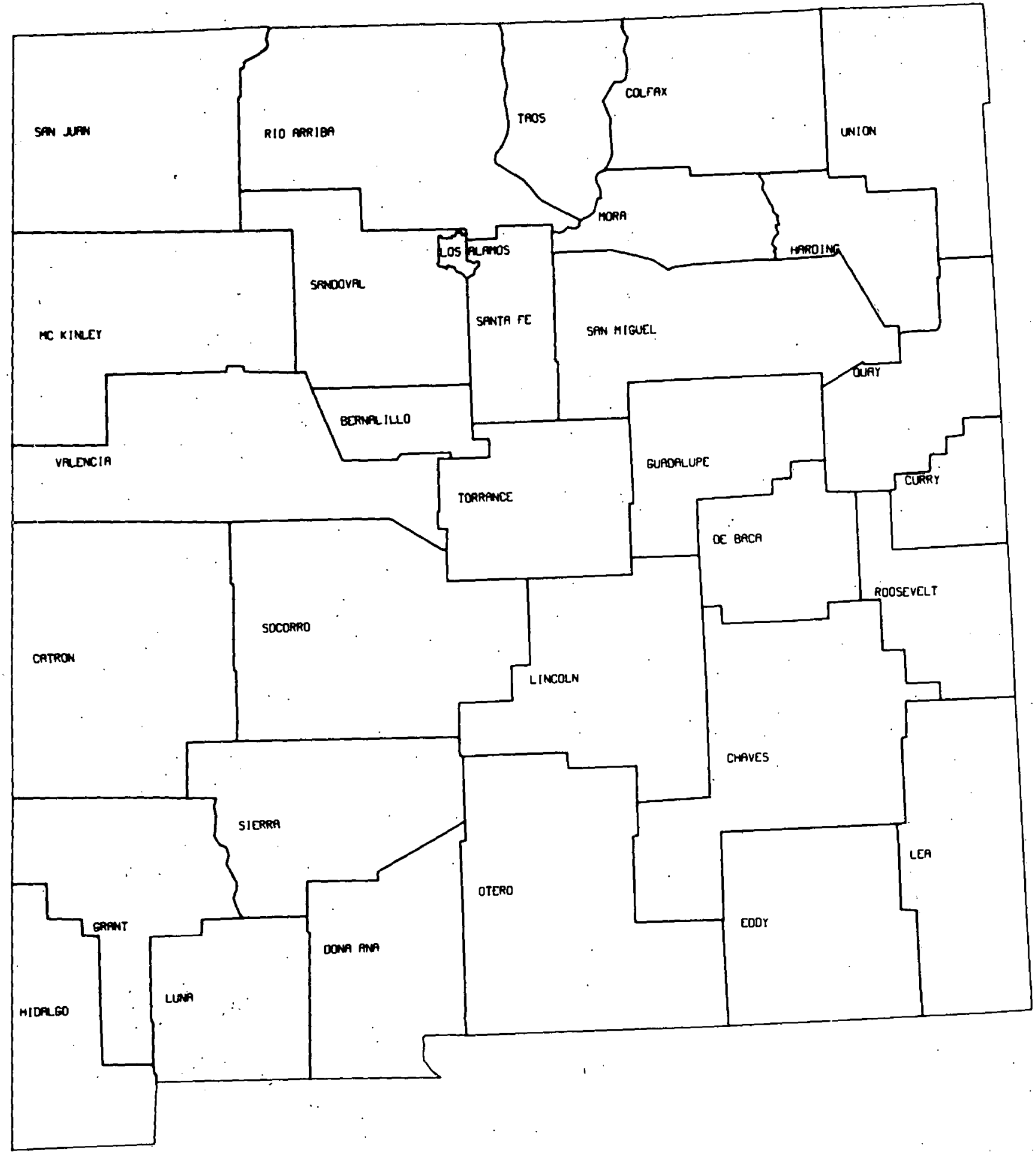

Fig. D.15 New Mexico: Key to Counties 


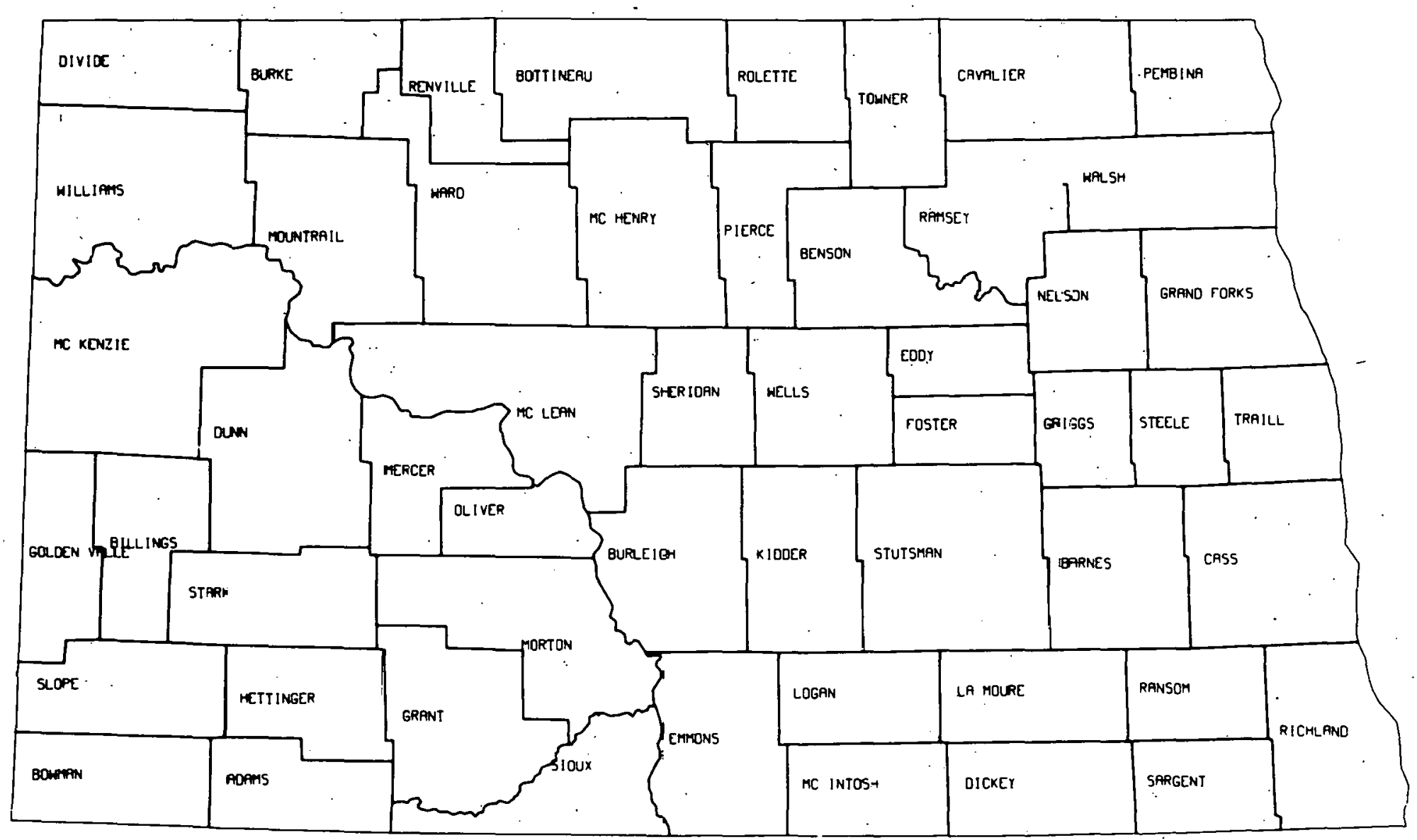

Fig. D.16 North Dakota: Key to Counties 


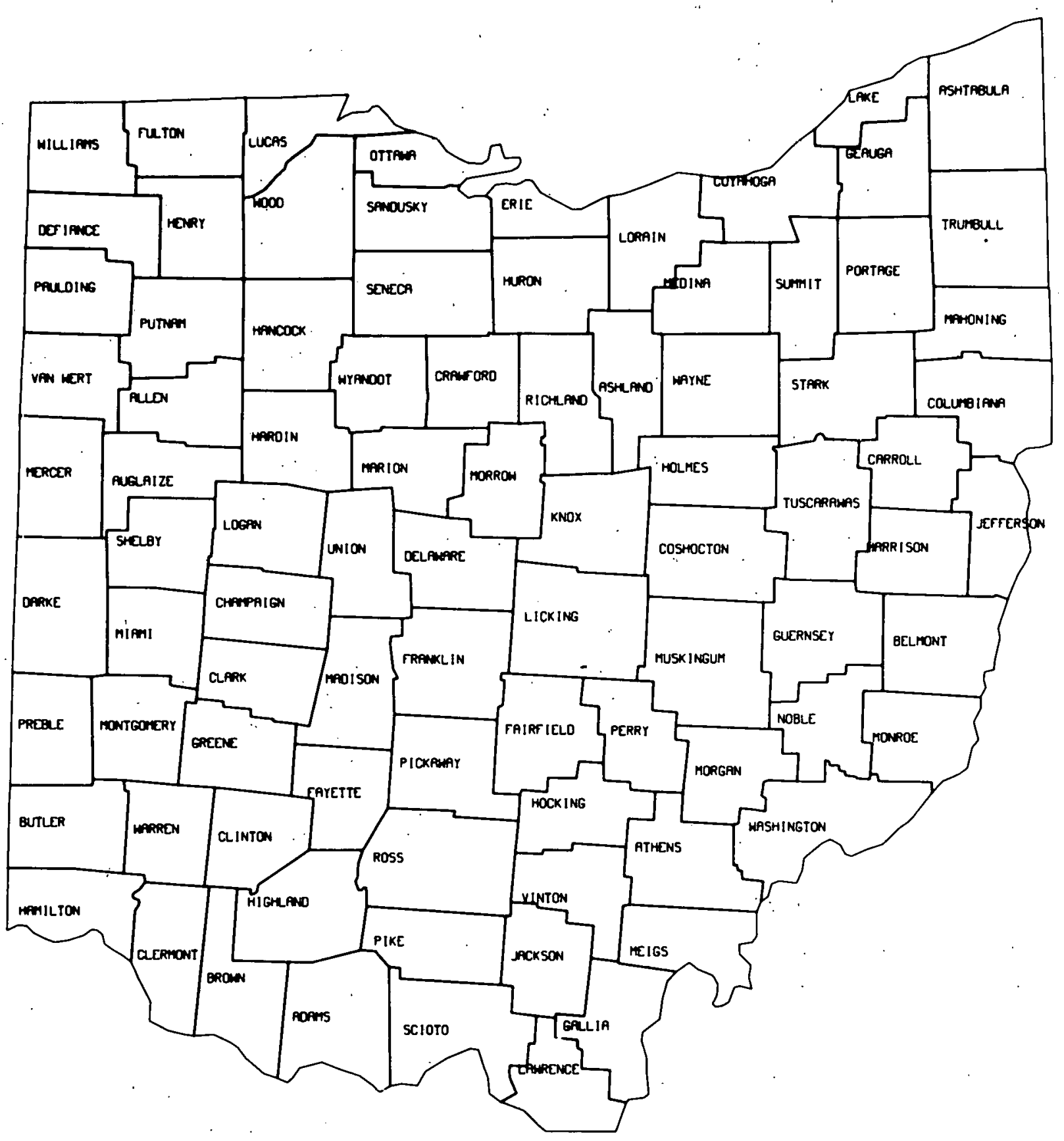

Fig. D.17 Ohio: Key to Counties 


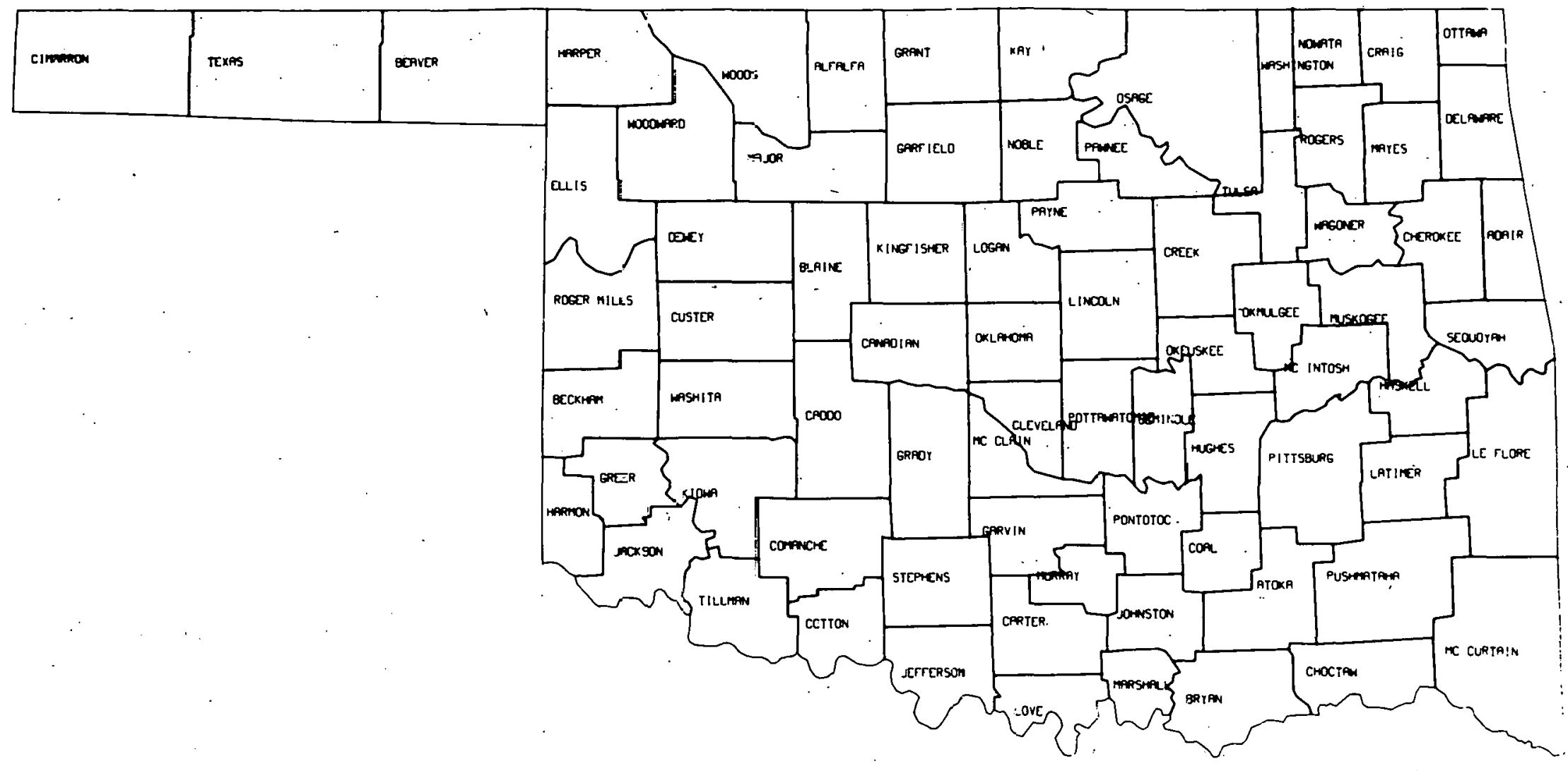

Fig. D.18 Oklahoma: Key to Counties 


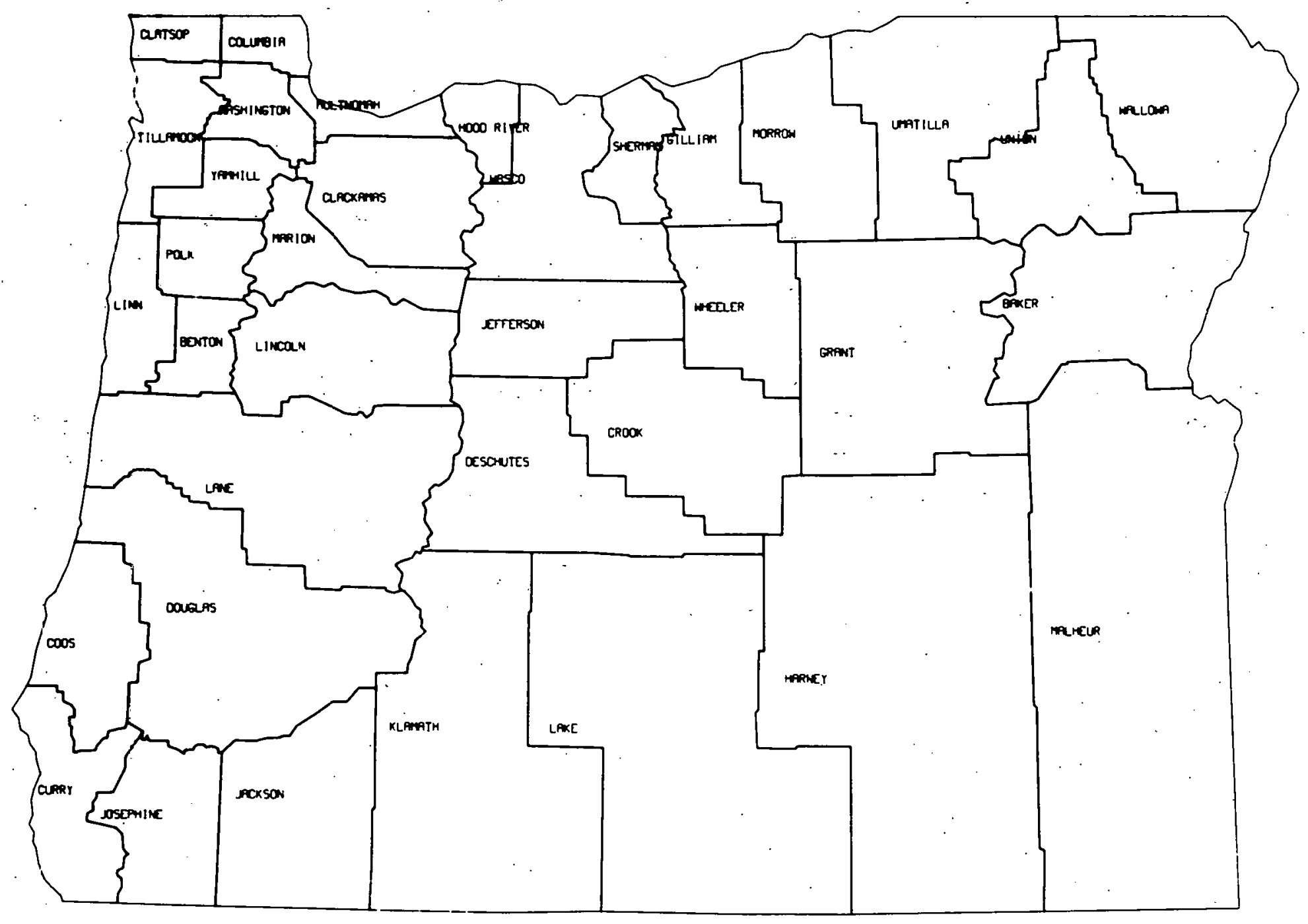

Fig. D.19 Oregon: Key to Counties 


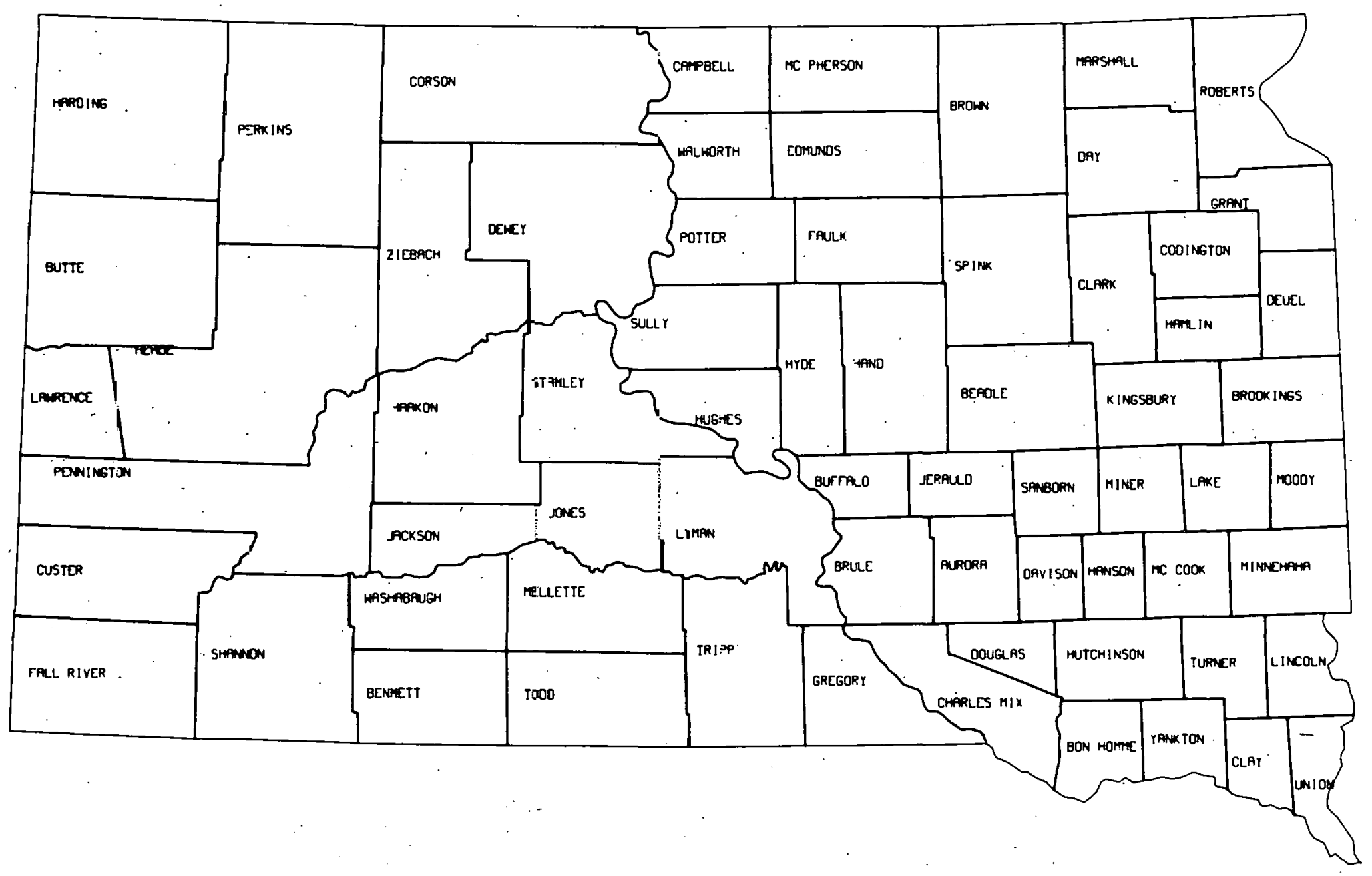

Fig. D.20 South Dakota: Key to Counties 


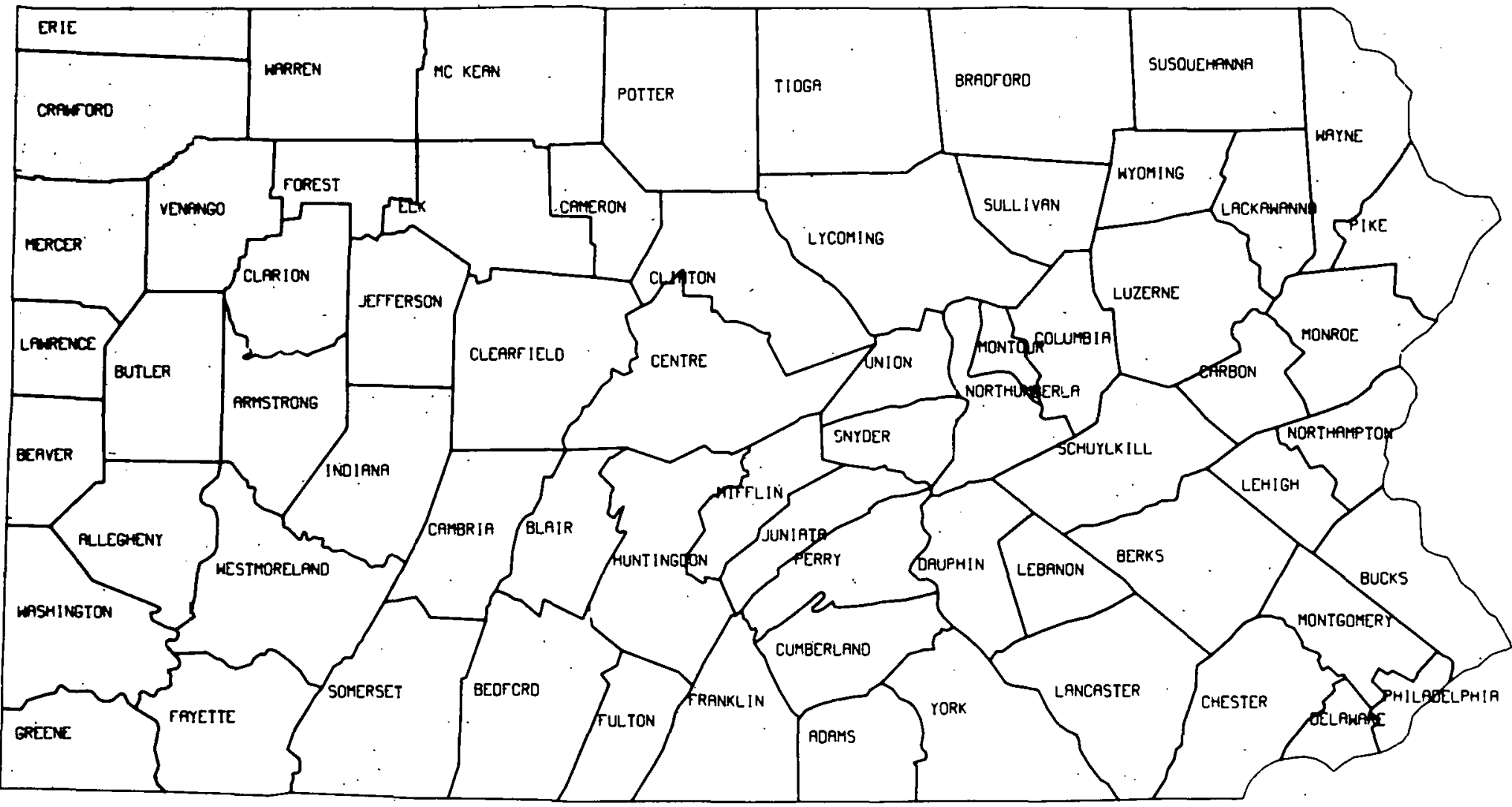

Fig. D.21 Pennsylvania: Key to Counties 


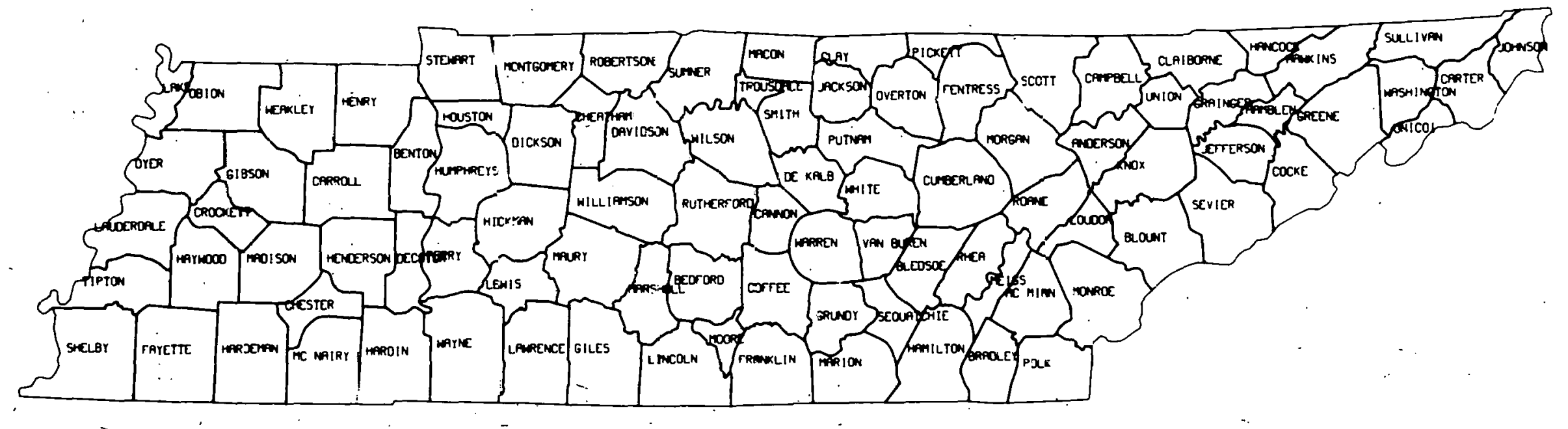

Fig. D.22 Tennessee: Key to Counties 


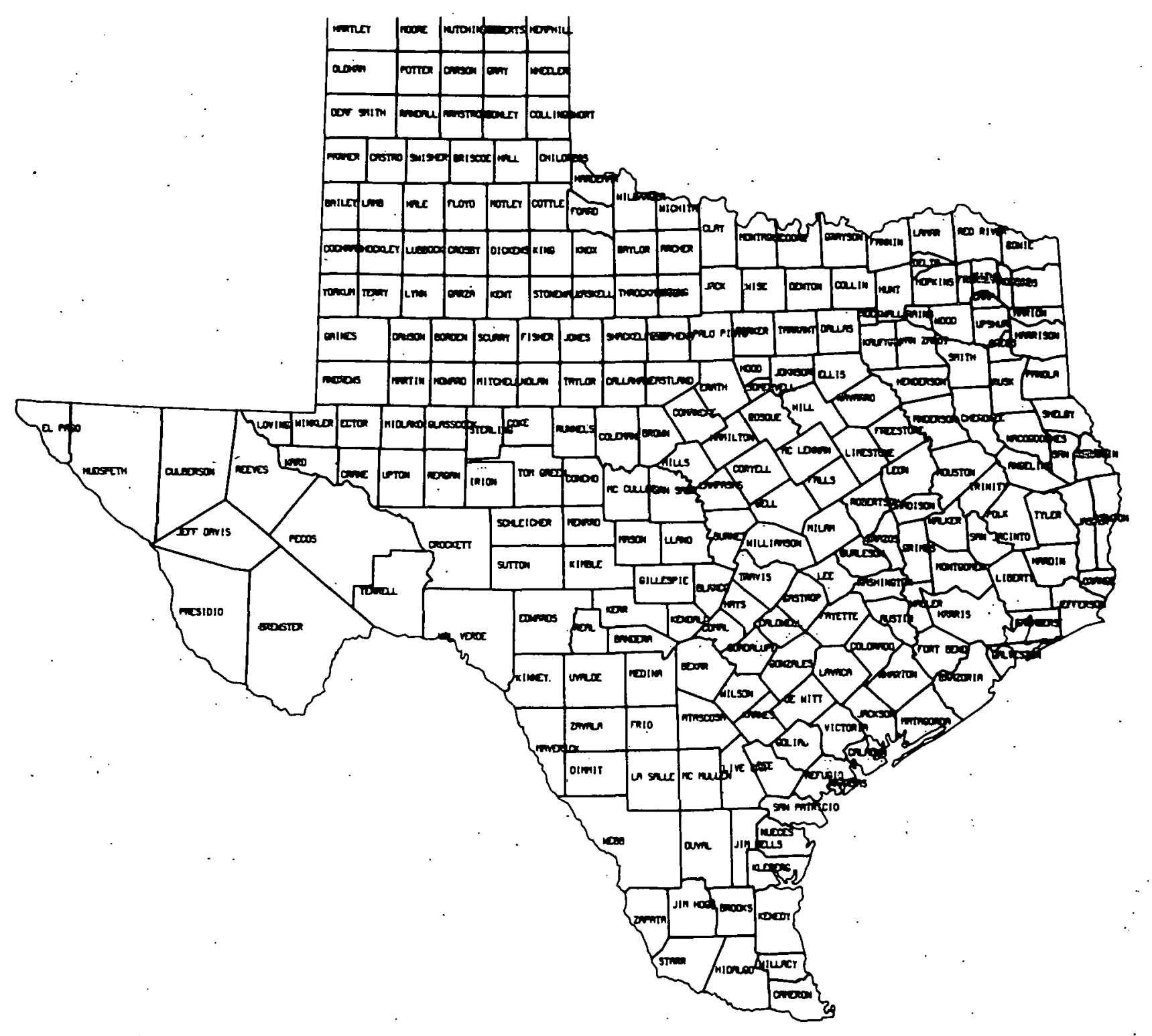

Fig. D.23 Texas: Key to Counties 


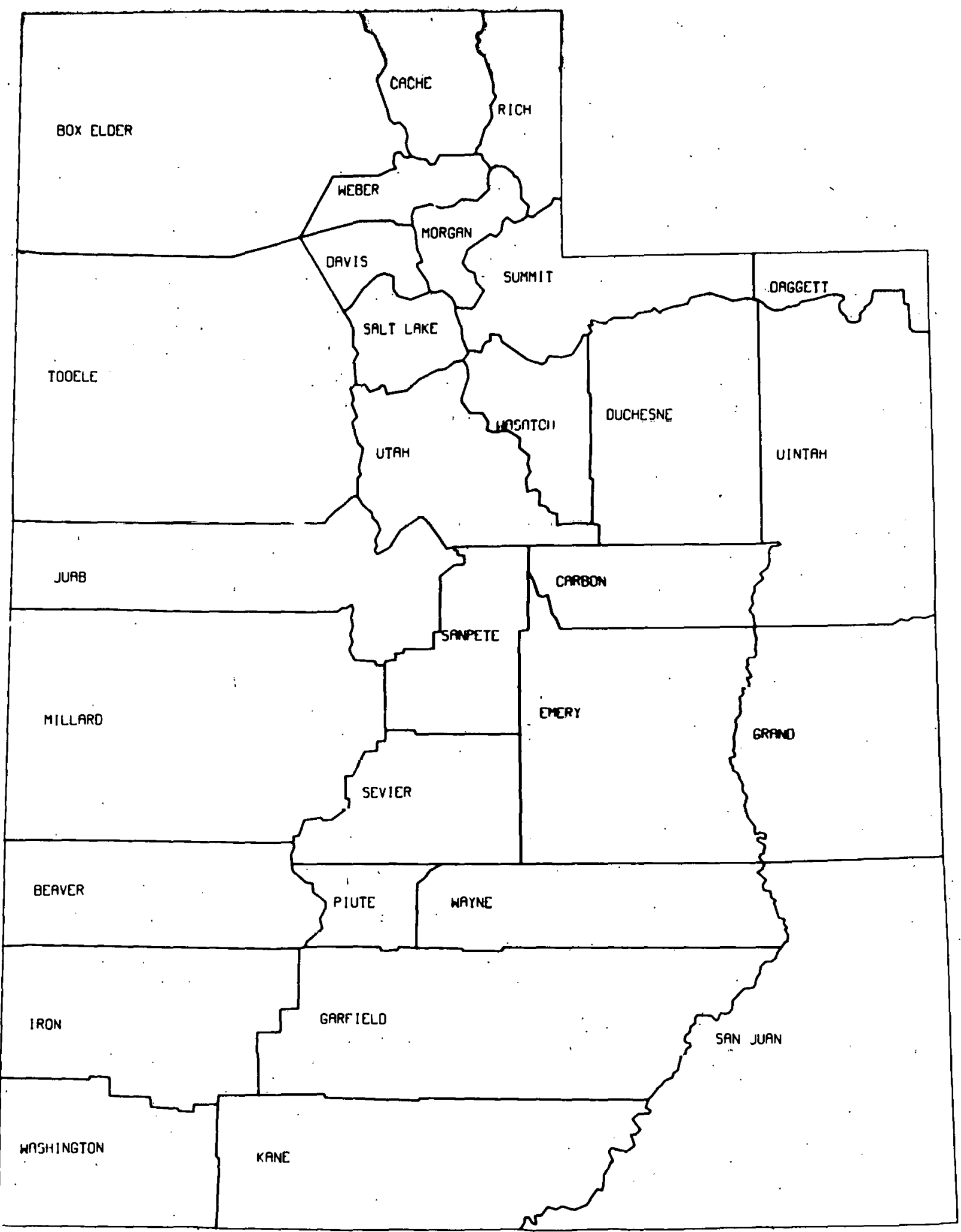

Fig. D.24 Utah: Key to Counties 


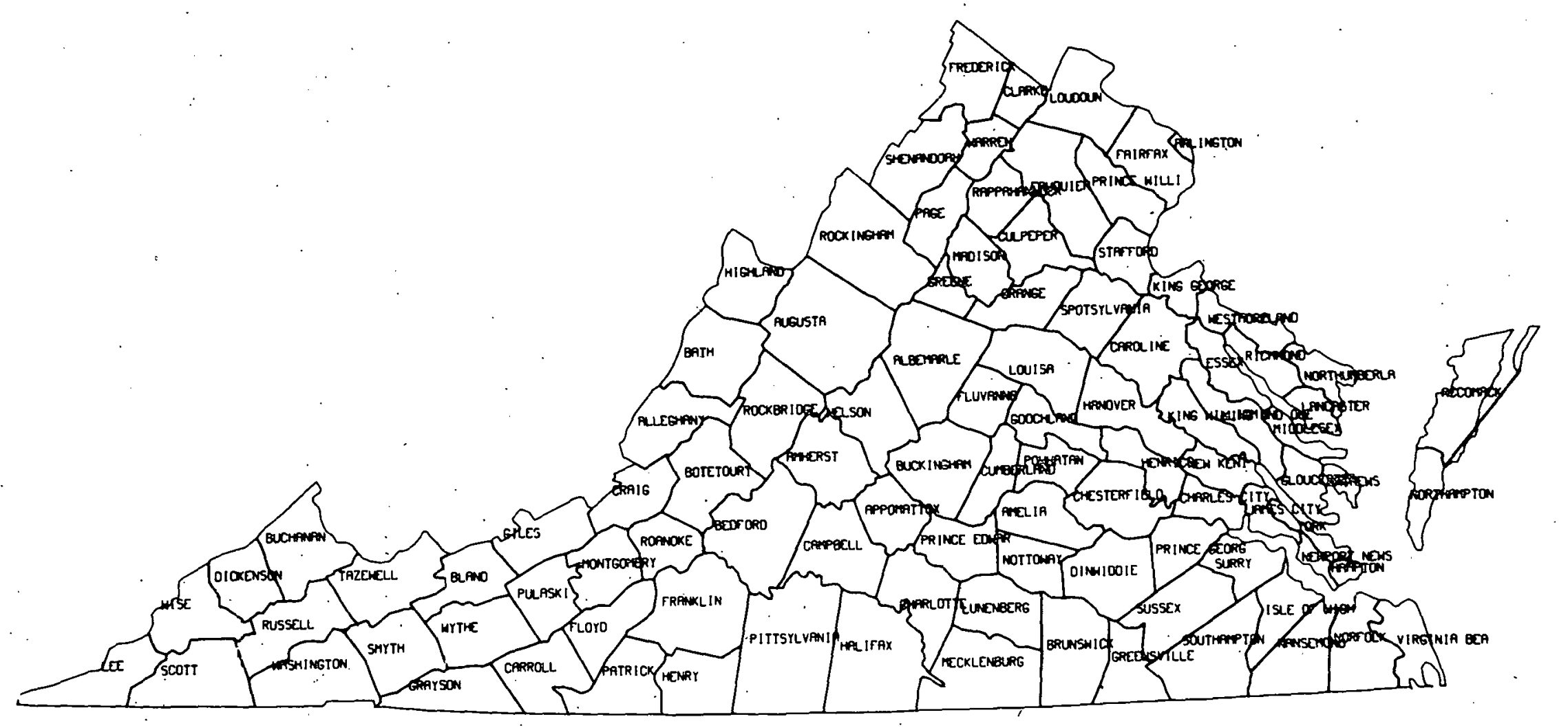

Fig. D.25 Virginia: Key to Counties 


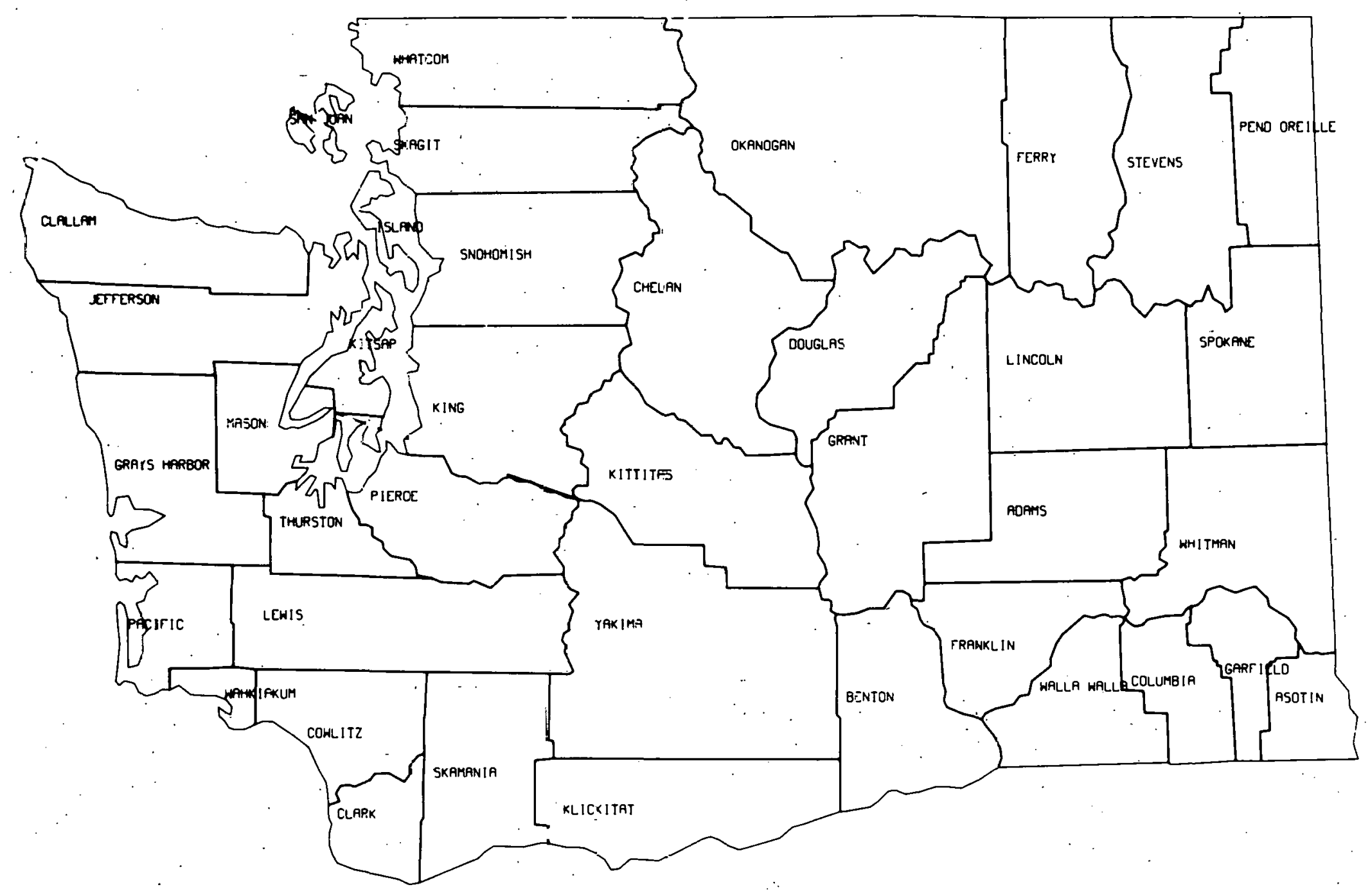

Fig. D.26 Washington: Key to Counties 


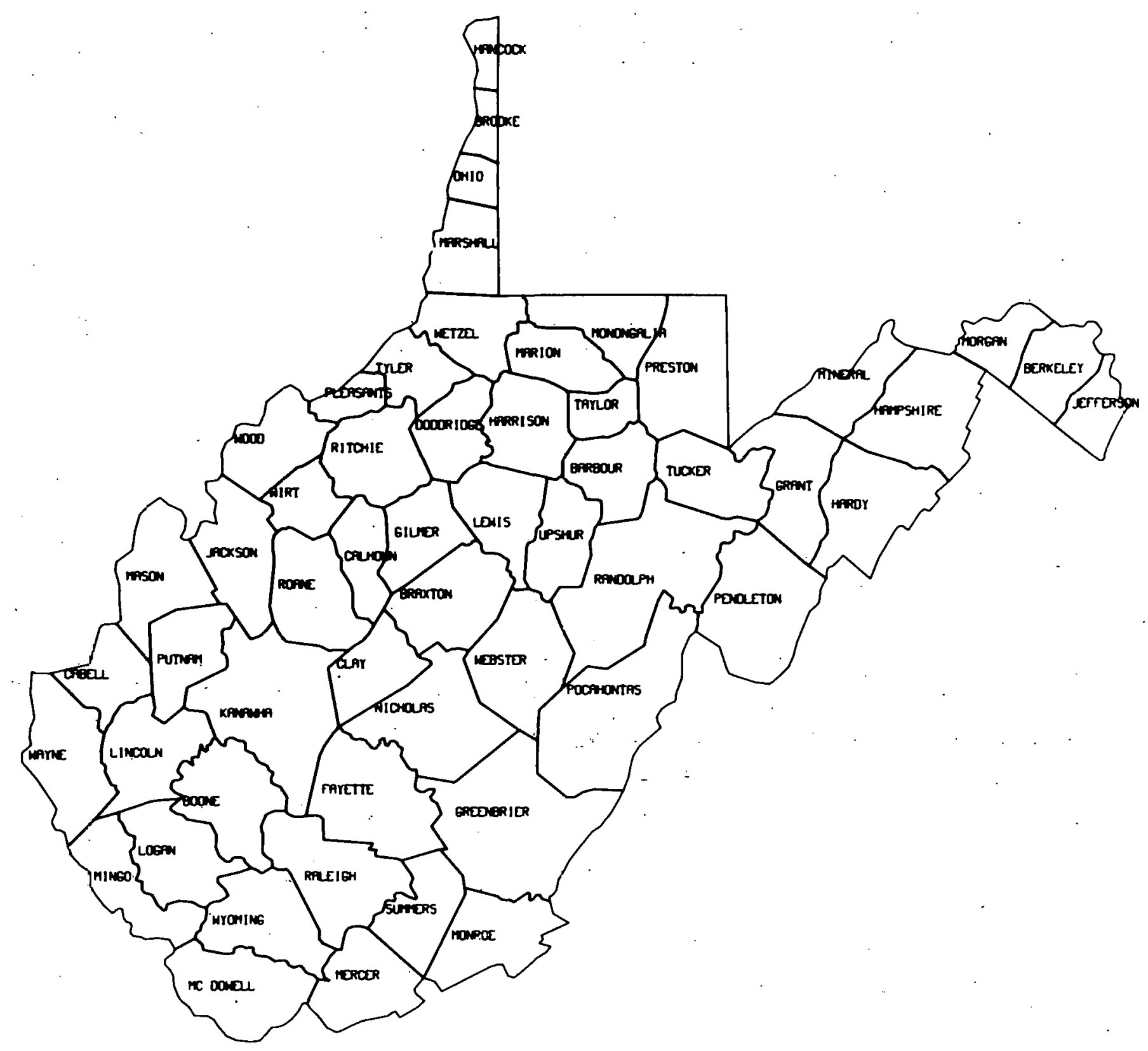

Fig. D.27 West Virginia:, Key to Counties 


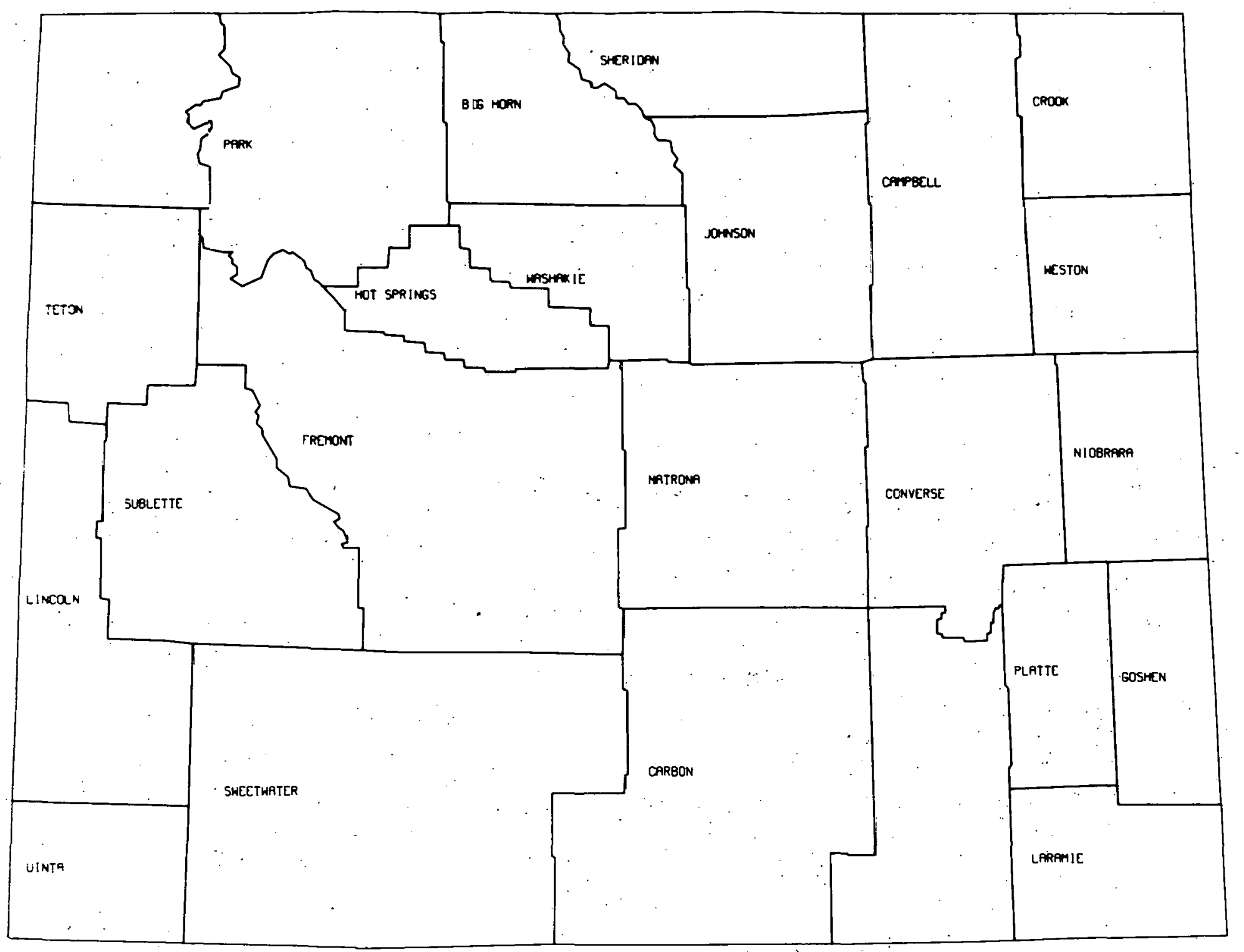

Fig. D.28 Wyomirg: Key to Counties 